Prepared in cooperation with the Virginia Department of Environmental Quality

\title{
Low-Flow Characteristics of Virginia Streams
}

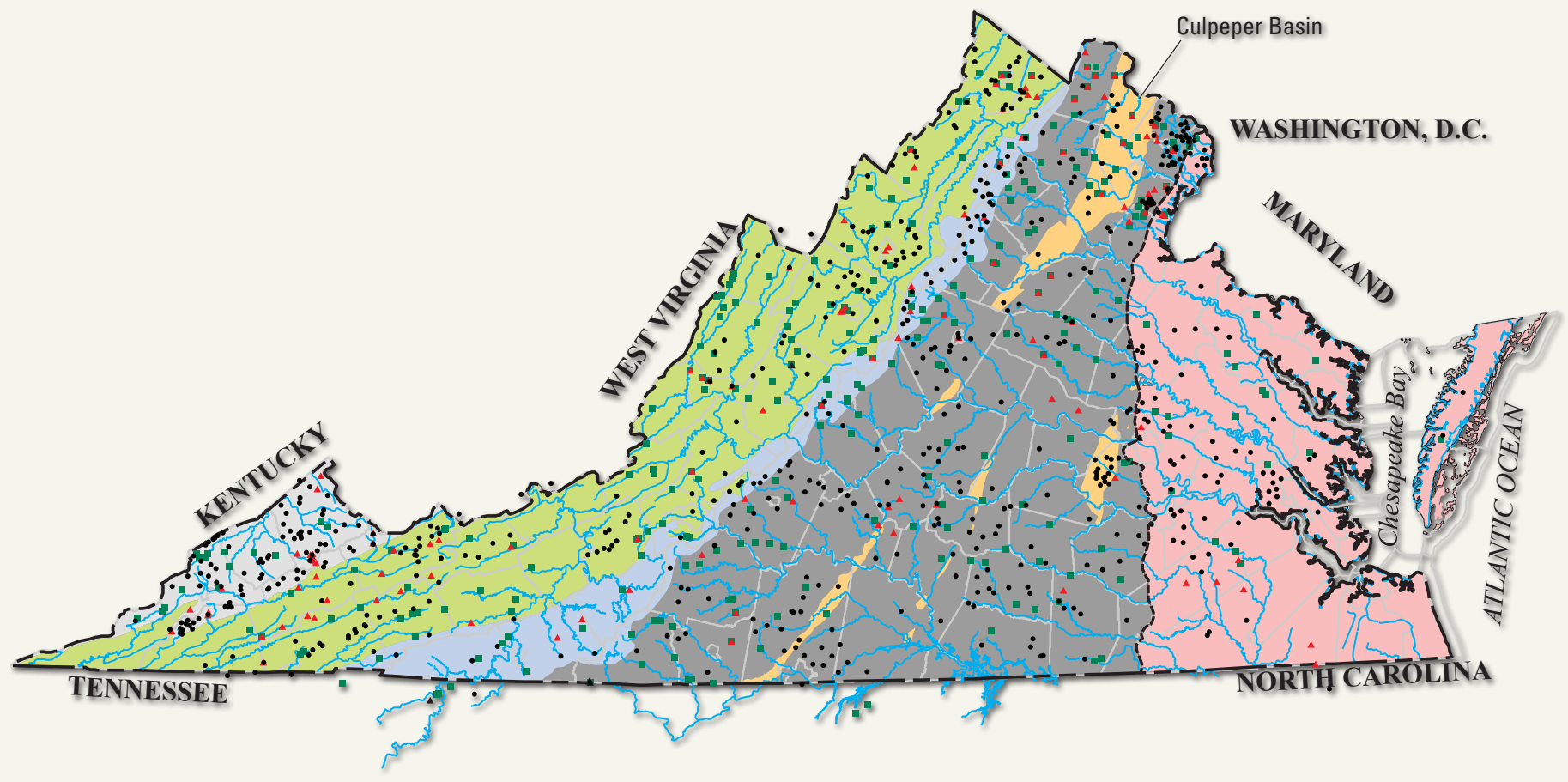

Scientific Investigations Report 2011-5143

U.S. Department of the Interior U.S. Geological Survey 
Cover art. See figure 1 (map showing low-flow study sites in Virginia). 


\section{Low-Flow Characteristics of Virginia Streams}

By Samuel H. Austin, Jennifer L. Krstolic, and Ute Wiegand

Prepared in cooperation with the Virginia Department of Environmental Quality

Scientific Investigations Report 2011-5143 


\title{
U.S. Department of the Interior \\ KEN SALAZAR, Secretary \\ U.S. Geological Survey \\ Marcia K. McNutt, Director
}

\author{
U.S. Geological Survey, Reston, Virginia: 2011
}

For more information on the USGS - the Federal source for science about the Earth, its natural and living resources, natural hazards, and the environment, visit http://www.usgs.gov or call 1-888-ASK-USGS.

For an overview of USGS information products, including maps, imagery, and publications, visit http://www.usgs.gov/pubprod

To order this and other USGS information products, visit http://store.usgs.gov

Any use of trade, product, or firm names is for descriptive purposes only and does not imply endorsement by the U.S. Government.

Although this report is in the public domain, permission must be secured from the individual copyright owners to reproduce any copyrighted materials contained within this report.

Suggested citation:

Austin, S.H., Krstolic, J.L., and Wiegand, Ute, 2011, Low-flow characteristics of Virginia streams: U.S. Geological Survey Scientific Investigations Report 2011-5143, 122 p. + 9 tables on CD.

(Also available online at http://pubs.usgs.gov/sir/2011/5143/.) 


\section{Contents}

Abstract

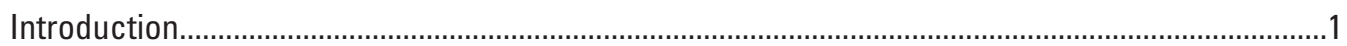

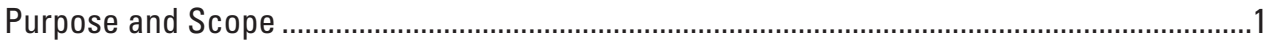

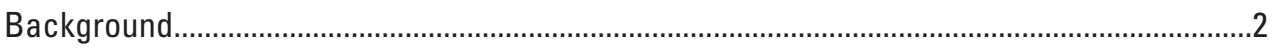

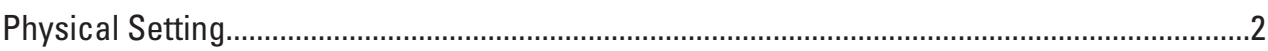

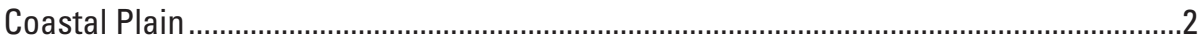

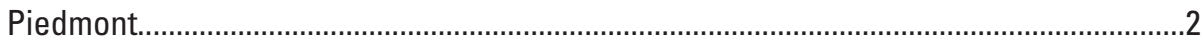

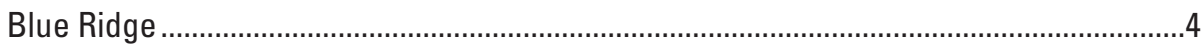

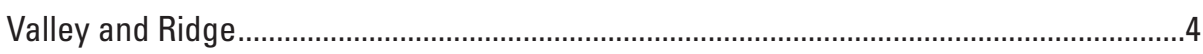

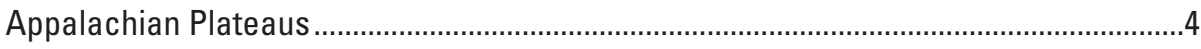

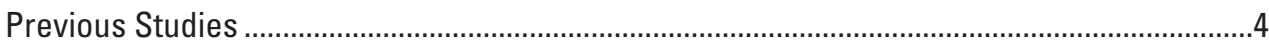

Approach .

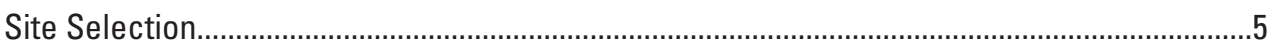

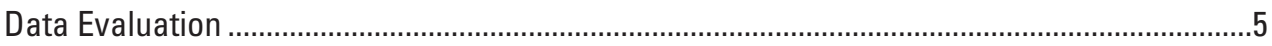

Monthly Streamflow Statistics .......................................................................................

Flow-Duration Curves.......................................................................................................

Low-Flow Frequency Analysis........................................................................................

Conditional-Probability Adjustment.............................................................................

MOVE.1 Regression Equations for Short-Term, Continuous-Record and Partial-Record Streamgaging Stations ......................................................................................

MOVE.1 Analyses for Short-Term, Continuous-Record Streamgaging Stations..............8

MOVE.1 Analyses for Partial-Record Streamgaging Stations .........................................8

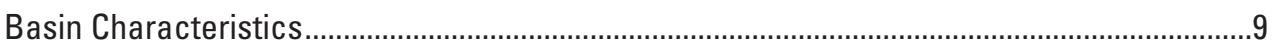

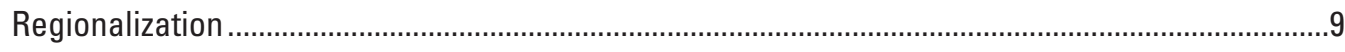

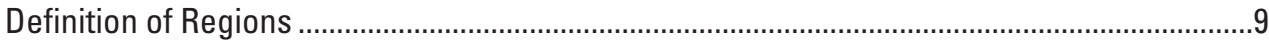

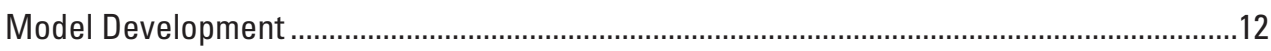

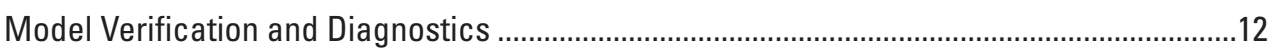

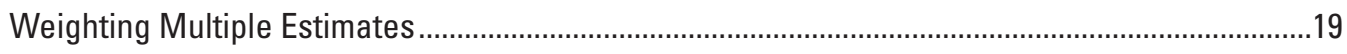

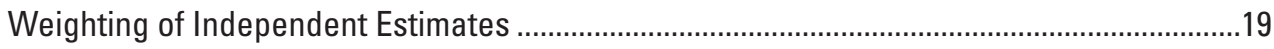

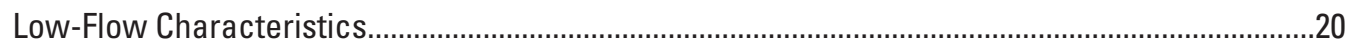

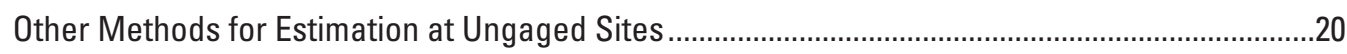

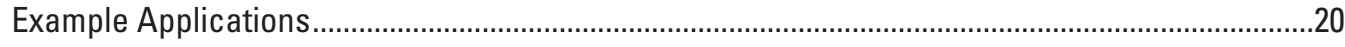

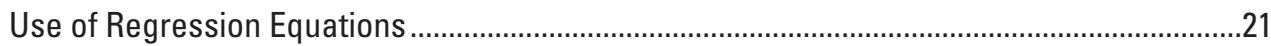

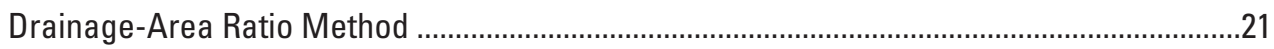

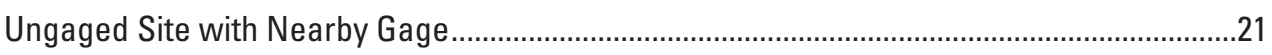

Gaged Site

Summary

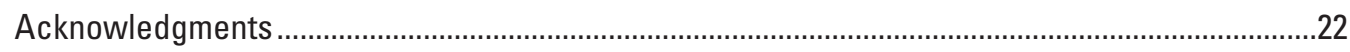

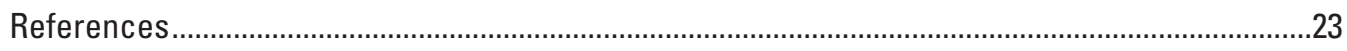

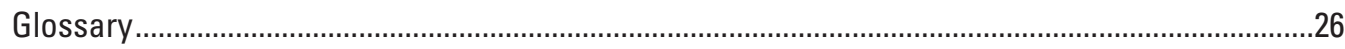




\section{Figures}

1. Map showing selected low-flow study sites and physiographic provinces for application of low-flow regional estimating equations..

2. Example leverage plots showing significant explanatory power, insignificant explanatory power, and evidence of collinearity.

\section{Tables}

1. Study sites and their identifying information CD in pocket

2. Monthly streamflow statistics for selected continuous-record streamgaging stations CD in pocket

3. Flow-duration statistics and flow variability indices for selected streamgaging stations. CD in pocket

4. Low-flow characteristics of streamgaging stations in Virginia .27

5. Low-flow MOVE.1 equations for selected short-term, continuous-record streamgaging stations. CD in pocket

6. Low-flow MOVE.1 equations for selected partial-record streamgaging stations CD in pocket

7. Statistics summarizing basin characteristics selected for regional regression of low flows in Virginia CD in pocket

8. Selected basin characteristics, their definitions, and datasources 10

9. Basin characteristics of low-flow streamgaging stations in Virginia. CD in pocket

10. Regional regression equations for estimating low flows of streams in Virginia

11. Low-flow characteristics for selected short-term, continuous-record streamgaging stations, transferred using the MOVE.1 method. CD in pocket

12. Low-flow characteristics for selected partial-record streamgaging stations, transferred using the MOVE.1 method CD in pocket 


\section{Conversion Factors}

\begin{tabular}{|c|c|c|}
\hline Multiply & By & To obtain \\
\hline \multicolumn{3}{|c|}{ Length } \\
\hline foot $(\mathrm{ft})$ & 0.3048 & meter $(\mathrm{m})$ \\
\hline mile (mi) & 1.609 & kilometer $(\mathrm{km})$ \\
\hline \multicolumn{3}{|c|}{ Area } \\
\hline acre & 0.4047 & hectare (ha) \\
\hline square foot $\left(\mathrm{ft}^{2}\right)$ & 0.09290 & square meter $\left(\mathrm{m}^{2}\right)$ \\
\hline square mile $\left(\mathrm{mi}^{2}\right)$ & 259.0 & hectare (ha) \\
\hline \multicolumn{3}{|c|}{ Volume } \\
\hline gallon (gal) & 0.003785 & cubic meter $\left(\mathrm{m}^{3}\right)$ \\
\hline cubic foot $\left(\mathrm{ft}^{3}\right)$ & 0.02832 & cubic meter $\left(\mathrm{m}^{3}\right)$ \\
\hline acre-foot (acre-ft) & 1,233 & cubic meter $\left(\mathrm{m}^{3}\right)$ \\
\hline \multicolumn{3}{|c|}{ Flow rate } \\
\hline acre-foot per day (acre-ft/d) & 0.01427 & cubic meter per second $\left(\mathrm{m}^{3} / \mathrm{s}\right)$ \\
\hline foot per second (ft/s) & 0.3048 & meter per second $(\mathrm{m} / \mathrm{s})$ \\
\hline cubic foot per second $\left(\mathrm{ft}^{3} / \mathrm{s}\right)$ & 0.02832 & cubic meter per second $\left(\mathrm{m}^{3} / \mathrm{s}\right)$ \\
\hline \multicolumn{3}{|c|}{ Hydraulic gradient } \\
\hline foot per mile ( $\mathrm{ft} / \mathrm{mi}$ ) & 0.1894 & meter per kilometer $(\mathrm{m} / \mathrm{km})$ \\
\hline
\end{tabular}

Vertical coordinate information is referenced to the North American Vertical Datum of 1988 (NAVD 88).

Horizontal coordinate information is referenced to the North American Datum of 1983 (NAD 83).

Altitude, as used in this report, refers to distance above the vertical datum. 



\title{
Low-Flow Characteristics of Virginia Streams
}

\author{
By Samuel H. Austin, Jennifer L. Krstolic, and Ute Wiegand
}

\section{Abstract}

Low-flow annual non-exceedance probabilities (ANEP), called probability-percent chance (P-percent chance) flow estimates, regional regression equations, and transfer methods are provided describing the low-flow characteristics of Virginia streams. Statistical methods are used to evaluate streamflow data. Analysis of Virginia streamflow data collected from 1895 through 2007 is summarized. Methods are provided for estimating low-flow characteristics of gaged and ungaged streams. The 1-, 4-, 7-, and 30-day average streamgaging station low-flow characteristics for 290 long-term, continuousrecord, streamgaging stations are determined, adjusted for instances of zero flow using a conditional probability adjustment method, and presented for non-exceedance probabilities of $0.9,0.8,0.7,0.6,0.5,0.4,0.3,0.2,0.1,0.05,0.02,0.01$, and 0.005 . Stream basin characteristics computed using spatial data and a geographic information system are used as explanatory variables in regional regression equations to estimate annual non-exceedance probabilities at gaged and ungaged sites and are summarized for 290 long-term, continuous-record streamgaging stations, 136 short-term, continuous-record streamgaging stations, and 613 partial-record streamgaging stations. Regional regression equations for six physiographic regions use basin characteristics to estimate 1-, 4-, 7-, and 30-day average low-flow annual non-exceedance probabilities at gaged and ungaged sites. Weighted low-flow values that combine computed streamgaging station low-flow characteristics and annual non-exceedance probabilities from regional regression equations provide improved low-flow estimates. Regression equations developed using the Maintenance of Variance with Extension (MOVE.1) method describe the line of organic correlation (LOC) with an appropriate index site for low-flow characteristics at 136 short-term, continuous-record streamgaging stations and 613 partial-record streamgaging stations. Monthly streamflow statistics computed on the individual daily mean streamflows of selected continuous-record streamgaging stations and curves describing flow-duration are presented. Text, figures, and lists are provided summarizing low-flow estimates, selected low-flow sites, delineated physiographic regions, basin characteristics, regression equations, error estimates, definitions, and datasources. This study supersedes previous studies of low flows in Virginia.

\section{Introduction}

Understanding low flows in Virginia streams is essential to sound management of our water resources and associated riparian and watershed ecosystems. Meaningful characterizations of the magnitude, frequency, and duration of low flows provide valuable insights into the dynamics and variability of water movement through these unique stream systems. Improved estimates of low flows provide data needed for the effective management of riparian systems and ecology associated with forested, agricultural, and urban landscapes. Low-flow estimates provide a basis for analysis of future streamflow response to changes in ecosystem and climate.

This report is the product of a cooperative partnership between the Virginia Department of Environmental Quality (DEQ) and the U.S. Geological Survey. The report describes the magnitude, frequency, and duration of low flows in Virginia streams. Low-flow characteristics are used to identify the reliability and sustainability of streamflows within the context of changing human demands and changing states of ecosystem organization. This information aids understanding of water use and the environmental health of watersheds and their associated ecosystems.

\section{Purpose and Scope}

The purpose of this report is to present the findings of a study to determine the magnitude, frequency, and duration of low flows in Virginia streams. This report summarizes a statistical analysis of low-flow characteristics of Virginia streams using data collected in Virginia from 1895 through 2007. Low-flow annual non-exceedance probabilities, called probability-percent chance (P-percent chance) flow estimates, and regional regression equations are used to describe the lowflow characteristics of Virginia streams. Statistical methods are used to evaluate streamflow data. Methods are provided for estimating low flow of gaged and ungaged streams. The 1-, 4-, 7-, and 30-day average streamgaging station low flows for 290 long-term, continuous-record streamgaging stations are determined, adjusted for instances of zero flow using a conditional probability adjustment method, and presented for non-exceedance probabilities of $0.9,0.8,0.7,0.6,0.5,0.4$, $0.3,0.2,0.1,0.05,0.02,0.01$, and 0.005 (recurrence intervals of $1.11,1.25,1.43,1.67,2.0,2.5,3.3,5,10,20,50,100$, 
and 200 years, respectively). Stream basin characteristics computed using spatial data and a geographic information system are used as explanatory variables in regional regression equations to estimate annual non-exceedance probabilities at gaged and ungaged sites and are summarized for 290 longterm, continuous-record streamgaging stations, 136 short-term, continuous-record streamgaging stations, and 613 partialrecord streamgaging stations. Regional regression equations for six physiographic regions use basin characteristics to estimate 1-, 4-, 7-, and 30-day average low-flow annual nonexceedance probabilities at gaged and ungaged sites. Weighted low-flow values that combine computed streamgaging station low-flow characteristics and annual non-exceedance probabilities from regional regression equations provide improved low-flow estimates. Regression equations developed using the Maintenance of Variance with Extension (MOVE.1) method describe a line of organic correlation (LOC) with an appropriate index site for low-flow characteristics at 136 short-term, continuous-record streamgaging stations and 613 partial-record streamgaging stations. Monthly streamflow statistics computed on the individual daily mean streamflows of 375 selected continuous-record streamgaging stations and statistics describing flow-duration are presented. Text, figures, and lists are provided summarizing low-flow estimates, selected low-flow sites, delineated physiographic regions, basin characteristics, regression equations, error estimates, definitions, and datasources. This study supersedes previous studies of low flows in Virginia.

\section{Background}

The DEQ and the U.S. Geological Survey (USGS) work cooperatively, maintaining a statewide network of more than 290 continuous streamgaging stations with many additional partial-record streamgaging stations. Together DEQ and USGS develop computations, analyses, and tools to support understanding and effective management of streamflows. These data and methods support evaluation and prediction by DEQ of streamwater low flows throughout Virginia.

\section{Physical Setting}

Virginia is located on the Atlantic Coast, bordered to the north by Maryland and West Virginia, to the south by North Carolina and Tennessee, and to the west by Kentucky and West Virginia (fig. 1). The total area of Virginia is approximately 41,000 square miles $\left(\mathrm{mi}^{2}\right)$. This includes almost $1,000 \mathrm{mi}^{2}$ of lakes, tidal rivers, and bays. There are more than 3,000 miles (mi) of nontidal rivers in Virginia and 5,000 mi of shoreline along the Atlantic Coast and Chesapeake Bay (Fenneman, 1938; Fenneman and Johnson, 1946).

Virginia lies within five physiographic provinces - the Coastal Plain, Piedmont, Blue Ridge, Valley and Ridge, and Appalachian Plateaus Physiographic Provinces. Each province, hereafter termed physiographic region or low-flow region, has distinctive geologic features and landforms. Geology ranges from unconsolidated sands and clays in the Coastal Plain physiographic region, to igneous and metamorphic rocks in the Piedmont and Blue Ridge physiographic regions, to sedimentary rocks, carbonate rocks, sandstone, and shale in the Valley and Ridge and Appalachian Plateaus physiographic regions (Hayes, 1991). Topography ranges from virtually flat in the Coastal Plain to highly dissected rugged terrain along the Blue Ridge and Appalachian crests. The central Piedmont is characterized by rolling hills and valleys, and is separated from the Valley and Ridge physiographic region by the Blue Ridge Mountains. Land-surface elevations range from 0 feet (ft) to over 5,000 ft above sea level (Fenneman, 1938).

\section{Coastal Plain}

The Coastal Plain physiographic region (Coastal Plain) generally consists of unconsolidated, gently sloping layers of sand and gravel separated by layers of clay and marl. The eastern boundary of the Coastal Plain is the Atlantic Ocean. The western boundary is the Fall Line, where the resistant rock of the Piedmont forms a contact with the unconsolidated sediments of the Coastal Plain (Fenneman, 1938). Sediments are thin at the Fall Line and thicken to as much as $6,000 \mathrm{ft}$ at the eastern edge of the Coastal Plain and are more than 13,000 ft thick under the Continental Shelf. These sediments rest on an eroded surface of Precambrian to early Mesozoic rock. Two-thirds of this material is composed of Late Jurassic and Cretaceous clay, sand, and gravel, which was stripped from the Appalachian mountains, carried eastward by rivers, and deposited in deltas in the newly formed Atlantic Ocean basin. A sequence of thin, fossiliferous marine sands of Tertiary age overlies the older strata. These sands were deposited in warm, shallow seas during repeated marine transgressions across the Coastal Plain (Hayes, 1991). This pattern of deposition was interrupted about 35 million years ago by a large meteorite that plummeted into a shallow sea and created a crater more than $55 \mathrm{mi}$ in diameter, termed the Chesapeake Bay impact structure, which was subsequently buried under about $4,000 \mathrm{ft}$ of younger sediment (Edwards and others, 2005). Rivers and streams are affected by tides over a substantial area (Fenneman, 1938; Fenneman and Johnson, 1946).

\section{Piedmont}

The Piedmont physiographic region (Piedmont) in Virginia consists of gently rolling terrain, which extends from the base of the Blue Ridge Mountains east to the Fall Line. It is the largest physiographic region in Virginia, is widest along the Virginia-North Carolina border (approximately $125 \mathrm{mi}$ wide), then narrows to about $25 \mathrm{mi}$ wide in northern Virginia. The Piedmont is formed mainly of metamorphic and igneous rocks that consist of granite, gneiss, schist, slate, phyllite, and quartzite. Triassic and Jurassic sedimentary rocks form several early Mesozoic Basins in the Piedmont that consist mainly of 


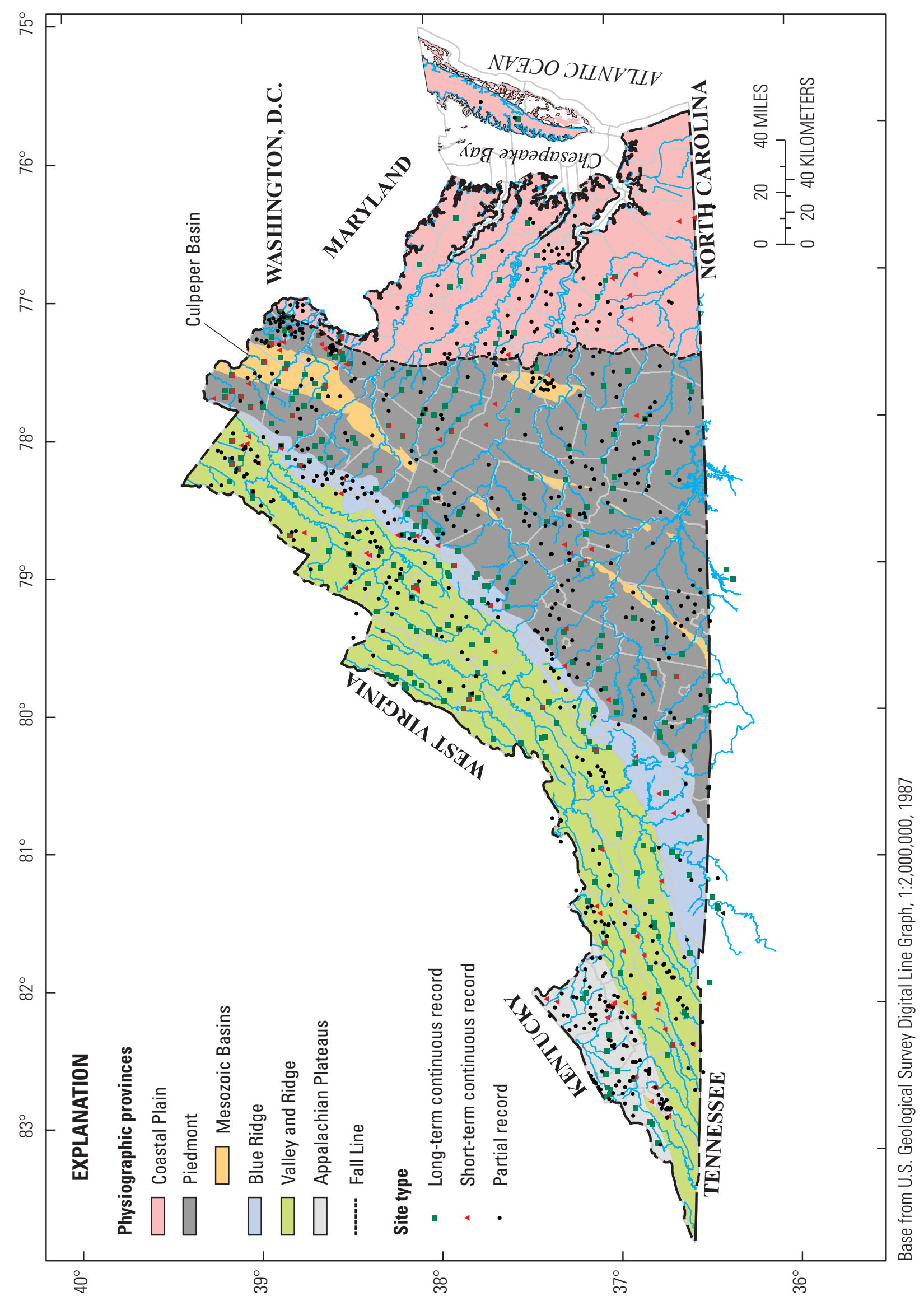

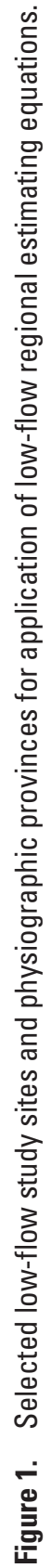


shales and sandstones intruded by diabase. Geologic formations of the Piedmont trend northeast-southwest and generally are covered by a deep (6 to $65 \mathrm{ft}$ ) layer of saprolite. Outcrops commonly are restricted to stream valleys where saprolite has been removed by erosion. The topography becomes somewhat more rugged with proximity to the Blue Ridge physiographic region, where local hills, knobs, or ridges of more resistant rock are present (Fenneman, 1938).

The Mesozoic Basins are located within the Piedmont, but they are evaluated as a separate physiographic region in this study because of their unique geomorphology and the associated improvements in explanatory power of basin characteristics in regional regression equations developed specifically for Mesozoic Basins. The Mesozoic Basins consist of sediments deposited in fault basins and are usually referred to as Triassic Basin deposits, though they are known to also contain lower Jurassic rocks. These basins formed when Africa separated from North America to create the Atlantic Ocean. The Culpeper basin, in the western Piedmont near the Blue Ridge physiographic region is the largest Mesozoic Basin in Virginia, but smaller basins, including the Richmond, Farmville, and Danville, are scattered throughout the Piedmont. Structurally, these are partially depressed blocks of land with a main fault on the western side. Ancient alluvial fan conglomerates fill these basins along the western borders, and deep red sediments fill the eastern portions of these basins. These red sediments often contain fish fossils or dinosaur tracks, indicating that tropical lakes and mudflats were present. Numerous igneous rocks and lava flows cut into these Triassic sediments and are remnants of the volcanic activity that accompanied the opening of the Atlantic Ocean (Hayes, 1991).

\section{Blue Ridge}

The Blue Ridge physiographic region (Blue Ridge) lies between the Valley and Ridge and the Piedmont. It is a fairly thin ridge of northeast-southwest-trending mountains consisting mainly of metamorphic and igneous rocks, with some sedimentary rock on the western slope. By the early Cambrian, the Iapetus Ocean had opened to the east of the Blue Ridge, and a westward transgression occurred along the ancient North American margin. In the western Blue Ridge, shallow marine siliclastics of the Chilhowee Group were deposited in the early Cambrian and eventually gave way to carbonates of Cambro-Ordovician age. In central and northern Virginia, the Blue Ridge Mountains rise to elevations exceeding 4,000 ft. Local relief on the east side of the Blue Ridge is up to 3,000 ft. In southern Virginia, the Blue Ridge forms a broad plateaulike upland that rises over 1,500 ft from the Piedmont along a prominent escarpment. Mt. Rogers $(5,728 \mathrm{ft})$, in the southwestern Virginia Blue Ridge, is the highest peak in Virginia. Steep slopes allow only thin soils in some areas, thus reducing the amount of groundwater storage (Hayes, 1991).

\section{Valley and Ridge}

The Valley and Ridge physiographic region (Valley and Ridge) was formed by the folding and faulting of sedimentary rocks. Northeast-southwest-trending ridges are formed by resistant quartzite, sandstone, and conglomerates, while narrow valleys are underlain by limestone, shale, and dolostone. The characteristic topography of this region is the result of differential weathering of linear belts of rocks that has been repeated by folding and faulting. Cambrian clastic sediments of the western Blue Ridge are overlain by carbonate rocks. For at least 70 million years, carbonates were deposited in a shallow, tropical ocean along the southeastern edge of North America. Today these carbonates, up to 2 mi thick, are exposed in the Great Valley, known as the Shenandoah Valley in central and northern Virginia, and in the easternmost portion of the Valley and Ridge. Well-developed karst topography is characteristic of the Great Valley, and many caverns are located in the subsurface (Hayes, 1991).

\section{Appalachian Plateaus}

The Appalachian Plateaus physiographic region (Appalachian Plateaus), locally known as the Cumberland Plateau, consists of westward-dipping, consolidated, sedimentary rocks composed mainly of sandstone, shale, and coal. It is located at the western end of Virginia. Extensive erosion has formed steep slopes and narrow valleys throughout this province. Although some parts exhibit a low relief plateau-like morphology, much of the Appalachian Plateaus is strongly dissected by stream erosion, and the topography is rugged. Regional-scale folds in the Appalachian Plateaus were formed in response to shortening on thrust faults that do not reach the present surface and are rooted to the east in the Valley and Ridge. The upper Paleozoic strata of the Plateaus are rich in mineral resources, such as coal, natural gas, and petroleum (Fenneman, 1938; Fenneman and Johnson, 1946).

\section{Previous Studies}

Previous studies have collected and reported low-flow data or analyzed low-flow characteristics for Virginia streams. Hayes (1991) provided a comprehensive analysis of low-flow characteristics in Virginia streams. A study by Nuckels (1970) analyzed long-term, continuous-record streamgaging stations throughout Virginia. Other studies have focused on portions of the State. These include studies by Cushing and others (1973), Trainer and Watkins (1975), Mohler and Hagan (1981), Smith (1981), Wetzel and Bettandorff (1986), Lynch (1987), and Lynch and others (1987). 


\section{Approach}

Low-flow characteristics were determined by frequency analysis of low-flow non-exceedance probabilities and annual and monthly flow-duration statistics. Study sites were selected, data were evaluated, basin characteristics were compiled, and low-flow frequency and duration analyses were performed. Regional regression equations were developed using frequency data and basin characteristics. Study results are presented in a series of tables.

\section{Site Selection}

Streamgaging stations with at least 10 years of continuous record were identified as long-term, continuous-record streamgaging stations. Streamgaging stations with less than 10 years of continuous record were identified as short-term, continuous-record streamgaging stations. A total of 426 continuous-record streamgaging stations met these criteria. There were 290 long-term, continuous-record streamgaging stations and 136 short-term, continuous-record streamgaging stations selected for study. More than 3,000 partial-record streamgaging stations were identified as candidates for low-flow characterization. Of these, 1,642 were identified as potential study sites, each having enough flow data upon which to perform statistical tests. Of these, 626 sites met a threshold of at least 10 low-flow discharge measurements considered necessary to create a meaningful index-site, partial-record site $x-y$ low-flow relation. Of these, 13 sites were removed from the final group of relations due to a lack of meaningful statistical relation between the paired $x-y$ datasets. A total of 613 sites were found to be suitable with viable statistical relations between partial-record flow data and corresponding, vetted, index-record site daily value flow data, from which index-site, partial-record site $x-y$ pairs were developed.

In each of these site categories, (1) long-term continuousrecord, (2) short-term continuous-record, and (3) partialrecord, data from candidate streamgaging stations were quality checked to identify any numerical errors. Then, tables were created for candidate streamgaging stations in each category, listing all datapoints over the period of record. Each list of datapoints was individually evaluated, using written accounts of past data-collection procedures and anecdotal information specific to each streamgaging site, to discover and segregate any intervals in the record in which concomitant effects such as data of poor quality or severely altered or regulated flows negatively affected the candidate data. Data within these impacted intervals were segregated from the larger dataset.

Similarly, using professional judgment, drainage basin area and usable watershed storage volume upstream from the streamgaging station were calculated for each candidate dataset in which regulation was suspected. If the calculated volume of usable water storage upstream from the streamgaging station met or exceeded 100 acre-feet per square mile, an amount considered to significantly regulate streamflow, then the affected streamflow data were eliminated from the analysis, potentially eliminating the streamgaging station as a candidate site (Benson, 1962, 1964). The streamgaging stations used in this study are listed in table 1 (compact disc (CD) in pocket).

\section{Data Evaluation}

For each long- and short-term continuous-record dataset, the annual 1-, 4-, 7-, and 30-day average low-flow climatic year (April 1 through March 31) time series were determined. Datapoints in each long- and short-term continuous-record time series, and datapoints from each partial-record dataset were plotted in time-series-specific, streamgaging stationspecific scatter plots, and each scatter plot was visually checked for evidence of trends. Summary statistics were generated for each dataset along with additional statistics useful for identifying trends in data and monotonic, non-monotonic, linear, and non-linear correlation, including (1) calculating Kendall's Tau, (2) creating an index of Kendall's trend probability, and (3) calculating Spearman's rho to help determine the strength of any linear or non-linear monotonic trend (Helsel and Hirsch, 2002). Also, (4) linear regression of each dataset with time and (5) plotting residuals were performed to help identify any significant correlation with time and, if evident, any negative or positive auto-correlation. Finally, (6) a runs test of each dataset was performed to help determine any significantly non-linear change over time using GraphPad Prism ${ }^{1}$.

The results of these statistical tests were summarized for each candidate dataset and used to help determine the degree of significant auto-correlation within the data from each candidate site. If no significant trend was evident at the 0.05 confidence level, the candidate site became part of the study pool in its site class. If a significant trend was evident, it was further evaluated to determine if (1) the trend could be directly attributed to a causal factor or (2) the trend produced values that exceed those normally expected from a random sample. If the trend could not be directly attributed to a causal factor or if trend values ranged within the bounds of expected statistical variation, then the trend was considered nonproblematic and no efforts were made to compensate for it by adjusting the streamgaging station dataset. If the trend could be attributed to a causal factor or trend values were determined to range outside the bounds of expected statistical variation, then several methods to evaluate the dataset and remove the trend were considered. These methods included (1) testing the dataset against an annual precipitation time series to identify any correlation with annual precipitation, (2) sampling from the dataset, then re-evaluating the auto-correlation of the sample, (3) grouping the data into alternate time periods and computing a summary statistic for the period, such as a

\footnotetext{
${ }^{1}$ GraphPad Prism version 5.0b, 2009, GraphPad Software, San Diego, California.
} 
time-weighted mean or median, and (4) removing the dataset from the pool of sites to be analyzed. If trends persisted in the revised dataset, then the candidate dataset was removed from consideration as a possible study site.

Of the 290 long-term, continuous-record candidate datasets considered for study, zero were removed from consideration because they either had too few datapoints available for analysis or characterized streams with excessively regulated flow, while 56 datasets were adjusted to remove data collected during periods of excessively regulated flow. Significant statistical trends were identified in 80 datasets. Of these, trends in 14 datasets were determined to be non-problematic, and trends in 66 datasets were determined as potentially problematic. The 66 potentially problematic datasets were detrended by sampling from the dataset and re-evaluating the auto-correlation of the sample.

Of the 136 short-term, continuous-record candidate datasets considered for study, zero were removed from consideration because they either had too few datapoints available for analysis or characterized streams with excessively regulated flow. Significant statistical trends were identified in zero of these datasets.

Of the over 3,000 partial-record candidate datasets considered for study, more than 1,358 were removed from consideration because they either had too few datapoints available for analysis, or characterized streams with excessively regulated flow. Of the remaining 1,642 sites, 1,016 were removed from consideration because a minimum of 10 low-flow measurements considered necessary to create a meaningful index-site, partial-record site $x$-y low-flow relation were lacking in the dataset, and 13 were removed from consideration because a suitable, vetted, index-record site with corresponding daily value flow data from which to develop an index-site, partial-record site $x-y$ pair could not be found. Of the remaining 613 sites, statistical trends were identified in zero datasets, and zero datasets were partially censored due to indications of excessively regulated flow.

\section{Monthly Streamflow Statistics}

Monthly streamflow statistics were determined in units of cubic feet per second and cubic feet per second per square mile for over 300 continuous-record streamgaging stations using USGS individual daily streamflow data collected over the period of record (USGS National Water Information System (NWIS) database accessed March 11, 2009). Streamflow statistics computed include the count of individual daily streamflow data values, the maximum, minimum, and median values sampled in each month, the arithmetic, geometric, and harmonic mean values for each month, the standard deviation of values in each month, and the monthly flow-duration value within each of the following percentile groupings: 5th percentile, 10 th percentile, 20 th percentile, 30 th percentile, 40 th percentile, 50th percentile, 60 th percentile, 70 th percentile, 80th percentile, and 90th percentile. Relative comparisons of inter-basin monthly streamflows may be made using monthly statistics presented in units of cubic feet per second per square mile. Relative comparisons of monthly low flows to other flows may be made using the monthly streamflow percentiles presented in groupings ranging from the 5 th percentile monthly flow to the 90th percentile monthly flow. Monthly streamflow statistics are listed in table 2 (CD in pocket).

\section{Flow-Duration Curves}

Flow-duration curves were developed for more than 300 continuous-record streamgaging stations using USGS individual daily value streamflow data collected over the period of record (USGS NWIS database accessed March 11, 2009). Flow-duration statistics were summarized and transferred to short-term, continuous-record and partial-record streamgaging stations using the MOVE.1 method. A flowduration curve is a cumulative frequency curve that shows the relation between streamflow and the percentage of time that it is equaled or exceeded. These curves may be used to answer questions such as, "what percentage of time is the daily value of flow data above (or below) a certain discharge value?" To create the curves, individual daily value streamflow data, expressed in cubic feet per second $\left(\mathrm{ft}^{3} / \mathrm{s}\right)$, were ranked from largest to smallest daily value, organized by percentile categories and plotted. Statistics from flow-duration curves are summarized in table 3 (CD in pocket).

In addition to daily value flow-duration statistics, a base-flow index, and Lane's variability index were computed for continuous-record, short-term continuous-record, and partial-record streamgaging stations. The ratio of daily value flow-duration statistics $\mathrm{Q}_{50}$ and $\mathrm{Q}_{90}$ is a useful index of the variability of base flow associated with stream low flow. For each streamgaging station, a base-flow index was computed as the $\log _{10}$ of the ratio of daily value flow-duration $Q_{50}$ to daily value flow-duration $Q_{90}$ (Nelms and others, 1997). Lane's variability index (Lane and Lei, 1950) was also computed for each streamgaging station; this index is a measure of the overall variability of the daily flow-duration values for a particular streamgaging station and is calculated as the standard deviation of the logarithms of the daily flow-duration values. Base-flow indices and Lane's variability indices are listed in table 3.

\section{Low-Flow Frequency Analysis}

Low-flow frequency analysis was used to determine the annual 1-, 4-, 7-, and 30-day average minimum lowflow climatic year time series and annual non-exceedance probabilities for long-term, continuous-record streamgaging stations. The $0.9,0.8,0.7,0.6,0.5,0.4,0.3,0.2,0.1,0.05$, $0.02,0.01$, and 0.005 annual non-exceedance probabilities were calculated. The climatic year was defined as April 1 through March 31. After these analyses were made, daily flow values from suitable long-term, continuous-record 
streamgaging stations were matched with daily flow values from short-term, continuous-record streamgaging stations, and instantaneous discharge measurements from partial-record streamgaging stations, to create index-site, short-term continuous, and index-site, partial-record x-y pairs. A line of organic correlation (LOC) was fitted to each set of x-y pairs using the Maintenance of Variance with Extension (MOVE.1) method, and low-flow frequencies were then described for each shortterm continuous-record site and each partial-record site as the transfer of the index-site flow statistic through the orthogonal LOC relation. For more information, see the section titled MOVE.1 Regression Equations for Partial-Record and ShortTerm, Continuous-Record Streamgaging Stations.

Low-flow frequency analysis began with calculation of the annual streamflow time series by climatic year for each average minimum flow of interest, yielding the 1-, 4-, 7-, and 30-day average minimum low-flow climatic year time series for each long-term, continuous-record streamgaging site. Each time series dataset was examined for suitability for frequency analysis, as previously described in the data evaluation section. A Log-Pearson Type III probability distribution was then fitted to each vetted annual low-flow time series, yielding a conditional-probability curve describing all flows as restricted by flow value and assumed to be non-zero. Selected, restricted low-flow characteristics were computed using a fitted LogPearson Type III parametric distribution of the form:

$$
X_{T}=\bar{X}+K S \text {, }
$$

where

$$
\begin{aligned}
X_{T}= & \text { the conditional low-flow statistic; } \\
\bar{X}= & \text { the mean of the annual events; } \\
S= & \text { the standard deviation of the logarithms of } \\
& \text { the annual events; and }
\end{aligned}
$$

The Log-Pearson Type III is a 3-parameter distribution, well suited to analyses of data tending to have lower limits but no upper bounds. The Log-Pearson Type III distribution also contains the log-normal distribution, as a special case, when the skew coefficient of the logarithmically transformed data equals zero. These attributes, combined with the flexibility of a 3-parameter distribution, make the Log-Pearson Type III parametric distribution well-suited to low-flow frequency analysis.

The Log-Pearson Type III conditional-probability curve was inspected for adequate fit and the conditional return period low flows for the 1-, 4-, 7-, and 30-year averaged time series were retrieved. If flow events with a magnitude of zero were present in an averaged time series, then the fitted conditionalprobability curve was adjusted, using conditional-probability adjustment methods described below, and yielding a fitted Log-Pearson Type III unconditional-probability curve describing low-flow probabilities not restricted by flow value. The unconditional-probability curve was inspected for adequate fit, and the unconditional return period low flows for the 1-, 4-, 7-, and 30-year averaged time series were retrieved. Retrieved return-period flows were tabulated, graphed, and organized by streamgaging station number and averaged-time series category. These data are summarized in table 4 (p. 27).

\section{Conditional-Probability Adjustment}

Methods of conditional probability adjustment (Jennings and Benson, 1969; Tasker, 1987), were used to adjust the annual non-exceedance probability Log-Pearson Type III lowflow curves, developed in the low-flow frequency analysis, for instances of zero flow. This was done by adjusting the Log-Pearson Type III distribution for cases where one or more elements of the annual 1-, 4-, 7-, or 30-day average low-flow time series were equal to zero.

The fitted Log-Pearson Type III parametric distribution has the form shown in eq 1 and is considered a conditional parametric distribution, or probability curve, because it describes the probability that a low flow is less than a particular flow threshold given that all flow remains non-zero.

The conditional probability adjustment creates an unconditional Log-Pearson Type III parametric distribution, in which the probability curve describing the low flow is not restricted by flow value.

The conditional probability adjustment is described by the following equation:

$$
X_{T}=\bar{X}+K^{*} S,
$$

where

$$
\begin{aligned}
& \begin{aligned}
X_{T} & =\text { the unconditional low-flow statistic; } \\
\bar{X} \text { and } S & =\text { mean and standard deviation respectively, }
\end{aligned} \\
& K^{*}=\text { the adjusted frequency factor calculated } \\
& \left\lfloor p\left(\frac{N}{n}\right)-\frac{N-n}{n}\right\rfloor \\
& N=\text { the total number of events in the low-flow } \\
& n=\text { the number of non-zero events, and } \\
& p=\text { the unconditional probability }(1 / T) \text {. }
\end{aligned}
$$

The numbers in table 4 are adjusted for zero flow using conditional probability adjustment. 


\section{MOVE.1 Regression Equations for Short- Term, Continuous-Record and Partial-Record Streamgaging Stations}

Regression equations describing low flows at partialrecord and short-term, continuous-record streamgaging stations as functions of flows at selected long-term, continuousrecord, index sites were prepared using the MOVE.1 method proposed by Stedinger and Thomas (Stedinger and Thomas, 1985). This method allows common logarithms $\left(\log _{10}\right)$ of streamflow daily values collected at a short-term, continuousrecord, streamgaging station, or instantaneous discharge measurements collected at a partial-record, streamgaging station (y-axis), to be plotted against corresponding common logarithms of streamflow daily values from an appropriate index site (x-axis). An ordinary least squares linear regression model of the form $y=a+b x$ is fitted to these transformed data, and the relation is then adjusted using the MOVE. 1 method, yielding an orthogonal LOC. The LOC may be used to estimate the common logarithm of stream low flow at the short-term, continuous- or partial-record site (y), as a function of the common logarithm of streamflow at the index-record site $(\mathrm{x})$, while preserving the statistical variance associated with each site. As the relation of low-flow values from either a partial-record site, or a short-term, continuous-record site, to a corresponding long-term, continuous-record site can be non-linear, the linear transformation of values afforded by the MOVE. 1 linear regression of the LOC of the common logarithms of each dataset can accommodate, yielding accurate transfer of values through the relation line.

\section{MOVE.1 Analyses for Short-Term, Continuous- Record Streamgaging Stations}

Regression equations describing low flows at short-term, continuous-record streamgaging stations were prepared using methods similar to those used for partial-record stations. One-hundred thirty-six (136) short-term, continuous-record streamgaging station datasets were evaluated as possible candidates for low-flow characterization using the MOVE.1 methodology. All of these datasets were identified as having enough flow data upon which to perform statistical tests. Statistics describing each dataset were developed and scattergrams of each dataset were prepared.

The daily flow values within the 136 short-term, continuous-record datasets were compared against the corresponding daily flow values within 251 vetted long-term, continuous-record datasets identified as candidate index sites. Three dimensionless indices, each expressed as a value from 0 to 1 , were created to facilitate the ranking and comparison of each potential x-y pair by (1) the number of coincident days in which daily flow data values were computed, expressed as a fraction of the number of daily flow data values computed at the short-term, continuous-record site, (2) the value of Spearman's rank correlation coefficient $\left(r_{s}\right)$ computed for each short-term, continuous-record site and candidate index site, and (3) a ranking of candidate index-site proximity to the short-term, continuous-record site, relative to the proximity of other candidate index sites. An overall ranking of candidate index-site, short-term, continuous-record site x-y pairs, computed as the sum of the three separate dimensionless indices, was used to facilitate creation of a list containing the top 20 ranked candidate index-site, short-term, continuousrecord site $x-y$ pairs. An orthogonal regression of the common logarithms of the measured daily flow values of the short-term, continuous-record site against the common logarithms of each of the top 20 candidate index sites was performed using the MOVE. 1 method, yielding a plot and LOC for each of the top 20 candidate pairs for each short-term, continuous-record site. Each of the candidate $x-y$ pair selections contained in the top 20 ranking list for each of the 136 short-term, continuousrecord regressions was then individually evaluated based on the orthogonal regression and additional statistical, empirical, and anecdotal information specific to each site. Then a best representative index-site, short-term, continuous-record site $\mathrm{x}-\mathrm{y}$ pair regression was selected. Zero index-site, short-term, continuous-record site $\mathrm{x}-\mathrm{y}$ pair regressions were removed from the final group of relations due to lack of a meaningful statistical relation between the $\mathrm{x}$ and $\mathrm{y}$ variables of the dataset. Low-flow frequencies were described for each short-term, continuous-record site as the transfer of the index-site flow statistic through the orthogonal LOC relation. Short-term, continuous-record site MOVE. 1 regression equations are listed in table 5 (CD in pocket).

\section{MOVE.1 Analyses for Partial-Record Streamgaging Stations}

More than 3,000 partial-record streamgaging station datasets were evaluated as possible candidates for low-flow characterization using the MOVE.1 methodology. Of these, 1,642 datasets were identified as having enough flow data upon which to perform statistical tests. Statistics describing each dataset were developed and scattergrams of each dataset were prepared. Based on statistical descriptions and visual checks of each scattergram it was determined that each partialrecord dataset should contain at least 10 low-flow discharge measurements in order to create a meaningful index-site, partial-record site $x-y$ relation. A subset of 626 partial-record datasets, each with more than 9 low-flow measurements, was identified for further analysis.

Flow data from partial-record streamgaging stations are instantaneous discharge measurements, and flow data from continuous-record streamgaging stations are daily flow values. The instantaneous discharge measurements within the 626 partial-record datasets were compared against the corresponding daily flow values within 255 vetted long-term, continuous-record datasets identified as candidate index sites. Three dimensionless indices, each expressed as a value from 0 to 1 , were created to facilitate the ranking and comparison of 
each potential $x-y$ pair by (1) the number of coincident days in which daily flow measurements were made, expressed as a fraction of the number of daily flow measurements taken at the partial-record site, (2) the value of Spearman's rank correlation coefficient $\left(r_{s}\right)$ computed for each partial-record site and candidate index site, and (3) a ranking of candidate index-site proximity to the partial-record site, relative to the proximity of other candidate index sites. An overall ranking of candidate index-site, partial-record site $x$-y pairs, computed as the sum of the three separate dimensionless indices, was used to facilitate creation of a list containing the top 20 ranked candidate index-site, partial-record site x-y pairs. An orthogonal regression of the common logarithms of the measured instantaneous discharge values of the partial-record site against the common logarithms of the daily flow values of each of the top 20 candidate index sites was performed using the MOVE. 1 method, yielding a plot and LOC for each of the top 20 candidate pairs for each partial-record site. Each of the candidate x-y pair selections contained in the top 20 ranking list for each of the 626 partial-record regressions was then individually evaluated based on the orthogonal regression and additional statistical, empirical, and anecdotal information specific to each site. Evaluations of each regression included review of statistical metrics and visual checks of each regression plot for variance, range, and goodness of fit. A best representative index-site, partial-record site $\mathrm{x}-\mathrm{y}$ pair regression was then selected. Thirteen (13) index-site, partial-record site $x-y$ pair regressions were removed from the final group of relations due to lack of a meaningful statistical relation between the paired $x-y$ datasets, bringing the total number of index-site, partial-record site $x-y$ paired regressions to 613. Low-flow frequencies were then described for each partial-record site as the transfer of the index-site flow statistic through the orthogonal LOC relation. Partial-record site MOVE.1 regression equations are listed in table 6 (CD in pocket).

\section{Basin Characteristics}

Measurements and statistics describing characteristics associated with delineated drainage basins in Virginia were developed and compiled for use as possible explanatory variables in low-flow regional regression analyses. These basin characteristics describing 312 unique attributes for each of 3,469 delineated drainage basins form a matrix of 1,082,328 values. The basin characteristics were compiled using ArcGIS $^{\mathrm{TM}^{2}}$ and data from the following sources: (1) a Virginia delineated drainage basin dataset (Hayes and Wiegand, 2006); (2) a USGS national hydrography dataset (U.S. Geological Survey, 2006); (3) a Natural Resources Conservation Service (NRCS) soil statistics dataset (U.S. Department of Agriculture, 2007); (4) a PRISM climate dataset (PRISM Climate Group, 2007); (5) a National Oceanic and Atmospheric Administration

${ }^{2}$ Arc-GIS, ESRI Inc., copyright 1999-2009, ESRI ArcMap 9.3.1 and ArcInfo Workstation GIS software, ESRI Inc., 380 New York Street, Redlands, California 92373-8100, USA.
(NOAA) rainfall intensity and climate dataset (National Oceanic and Atmospheric Administration, 2007; Paybins, 2008); (6) a USGS 2005 geology dataset (Dicken and others, 2005); (7) a USGS 2007 national elevation dataset (U.S. Geological Survey, 2007); and (8) a physiography dataset for the United States (Fenneman, 1938). Statistics summarizing basin characteristics selected for regional regression of low flows in Virginia are listed in table 7 (CD in pocket). A description of these basin characteristics, their definitions, and datasources can be found in table 8. A table of basin characteristics chosen for possible use in candidate regional regression models can be found in table 9 (CD in pocket). Drainage-basin boundaries were obtained from the delineated drainage basin dataset listed above (Hayes and Wiegand, 2006).

\section{Regionalization}

Regional regression analysis was used to develop equations for estimating the frequency of low flows at ungaged sites in Virginia. These equations relate the annual non-exceedance probability flows computed using low-flow frequency analysis of data from long-term gages to the measured basin characteristics of delineated drainage basins.

Six physiographic regions were used to organize regression analyses of basin characteristics against low-flow estimates. These six physiographic regions are similar to the five physiographic provinces identified in the discussion of physical setting except that the Mesozoic Basins, considered a subset of the Piedmont Physiographic Province, are identified separately as one of the six physiographic regions. The rationale for this organizational framework, that physiographic differences expressed in these six regions are related to hydrologic response, appeared to be a sound rationale because candidate regression models significantly improved across the range of low-flow probabilities as a consequence of these regressions based on physiographic regions.

\section{Definition of Regions}

The six regions delineated and used to evaluate low flows are Coastal Plain, Piedmont, Mesozoic Basins, Blue Ridge, Valley and Ridge, and Appalachian Plateaus (fig. 1). Each region was identified using Arc-GISTM to perform spatial separations of the geologic dataset. Regions were selected and identified iteratively, based on the improved explanatory power of candidate regression models associated with the regions across the range of low-flow annual non-exceedance probabilities. Exploratory statistical analyses helped improve the explanatory power of regional regression models. The Mesozoic Basins, usually grouped with the Piedmont physiographic region, were explicitly identified as a unique region for the purposes of this study, leading to improved correlations among candidate regional regression models. 
Table 8. Selected basin characteristics, their definitions, and datasources.

[ft, foot; $\mathrm{mi}^{2}$, square mile; $\mathrm{ft} / \mathrm{mi}$, foot per mile; $\mathrm{DD}$, decimal degrees; mi, mile; in., inch]

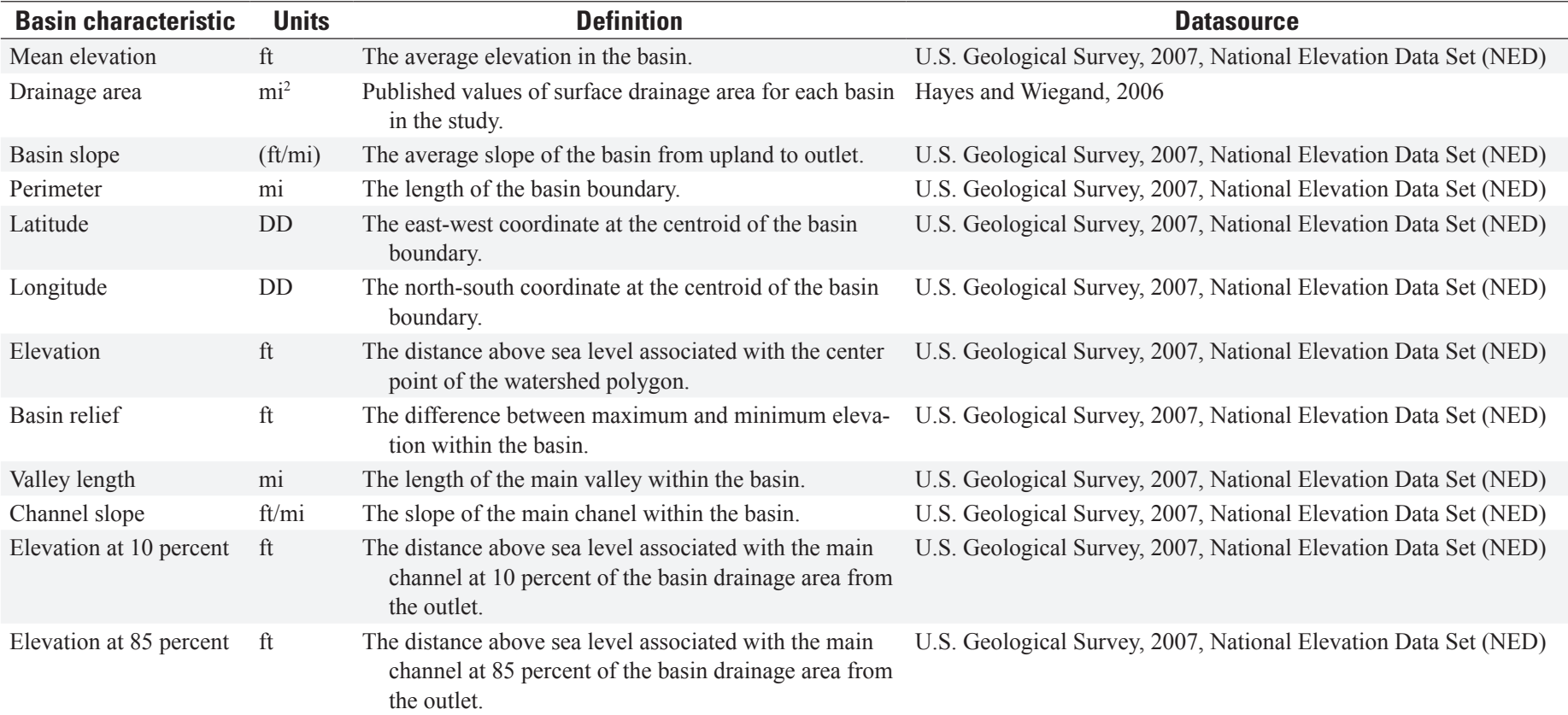

\begin{tabular}{|c|c|c|}
\hline Stream length & $\mathrm{mi}$ & $\begin{array}{l}\text { Length along the main channel from the outlet to the } \\
\text { basin divide. }\end{array}$ \\
\hline Forest & percent & Fraction of basin land area classified as forest. \\
\hline Urban & percent & Fraction of basin land area classified as urban area. \\
\hline Agriculture & percent & $\begin{array}{l}\text { Fraction of basin land area classified as agricultural } \\
\text { land. }\end{array}$ \\
\hline Wetland & percent & Fraction of basin land area classified as wetland. \\
\hline Water & percent & Fraction of basin land area classified as surface water. \\
\hline Grass & percent & Fraction of basin land area classified as grassland. \\
\hline Bare & percent & Fraction of basin land area classified as exposed soil. \\
\hline $\begin{array}{l}\text { Basin area in Coastal } \\
\text { Plain physiographic } \\
\text { region }\end{array}$ & $\mathrm{mi}^{2}$ & Area within the Coastal Plain physiographic region. \\
\hline Basin area in Piedmont & $\mathrm{mi}^{2}$ & Area within the Piedmont physiographic region. \\
\hline
\end{tabular}
physiographic region

Basin area in Blue $\quad \mathrm{mi}^{2} \quad$ Area within the Blue Ridge physiographic region. Ridge physiographic region

Basin area in Valley and $\mathrm{mi}^{2} \quad$ Area within the Valley and Ridge physiographic region. Ridge physiographic region

Basin area in Appala- $\quad \mathrm{mi}^{2}$ chian Plateaus physiographic region

Basin area in Mesozoic $\mathrm{mi}^{2}$ Basins physiographic region

Basin area in water

Basin area in Coastal Plain physiographic region

Basin area in Piedmont physiographic region

Basin area in Blue Ridge physiographic region $\mathrm{mi}^{2}$

Area covered in surface water.

Area within the Appalachian Plateaus physiographic region.

Area within the Mesozoic Basins physiographic region.

percent Percent of the basin within the Coastal Plain physiographic region.

percent Percent of the basin within the Piedmont physiographic region.

percent Percent of the basin within the Blue Ridge physiographic region.
U.S. Geological Survey, 2006, National Hydrography Dataset

Homer and others, 2004, http://www.mrlc.gov/nlcd.php

Homer and others, 2004, http://www.mrlc.gov/nlcd.php

Homer and others, 2004, http://www.mrlc.gov/nlcd.php

Homer and others, 2004, http://www.mrlc.gov/nlcd.php

Homer and others, 2004, http://www.mrlc.gov/nlcd.php

Homer and others, 2004, http://www.mrlc.gov/nlcd.php

Homer and others, 2004, http://www.mrlc.gov/nlcd.php

Fenneman and Johnson, 1946; Mixon and others, 1989; Dicken and others, 2005

Fenneman and Johnson, 1946; Mixon and others, 1989; Dicken and others, 2005

Fenneman and Johnson, 1946; Mixon and others, 1989; Dicken and others, 2005

Fenneman and Johnson, 1946; Mixon and others, 1989; Dicken and others, 2005

Fenneman and Johnson, 1946; Mixon and others, 1989; Dicken and others, 2005

Fenneman and Johnson, 1946; Mixon and others, 1989; Dicken and others, 2005

Fenneman and Johnson, 1946; Mixon and others, 1989; Dicken and others, 2005

Fenneman and Johnson, 1946; Mixon and others, 1989; Dicken and others, 2005

Fenneman and Johnson, 1946; Mixon and others, 1989; Dicken and others, 2005

Fenneman and Johnson, 1946; Mixon and others, 1989; Dicken and others, 2005 
Table 8. Selected basin characteristics, their definitions, and datasources.-Continued

[ft, foot; $\mathrm{mi}^{2}$, square mile; ft/mi, foot per mile; DD, decimal degrees; mi, mile; in., inch]

\begin{tabular}{|c|c|c|c|}
\hline Basin characteristic & Units & Definition & Datasource \\
\hline $\begin{array}{l}\text { Basin area in Valley and } \\
\text { Ridge physiographic } \\
\text { region }\end{array}$ & percent & $\begin{array}{l}\text { Percent of the basin within the Valley and Ridge physio- } \\
\text { graphic region. }\end{array}$ & $\begin{array}{l}\text { Fenneman and Johnson, 1946; Mixon and others, 1989; Dicken and } \\
\text { others, } 2005\end{array}$ \\
\hline $\begin{array}{l}\text { Basin area in Appala- } \\
\text { chian Plateaus phys- } \\
\text { iographic region }\end{array}$ & percent & $\begin{array}{l}\text { Percent of the basin within the Appalachian Plateaus } \\
\text { physiographic region. }\end{array}$ & $\begin{array}{l}\text { Fenneman and Johnson, 1946; Mixon and others, 1989; Dicken and } \\
\text { others, } 2005\end{array}$ \\
\hline $\begin{array}{l}\text { Basin area in Mesozoic } \\
\text { Basins physiographic } \\
\text { region }\end{array}$ & percent & $\begin{array}{l}\text { Percent of the basin within the Mesozoic Basins physio- } \\
\text { graphic region. }\end{array}$ & $\begin{array}{l}\text { Fenneman and Johnson, 1946; Mixon and others, 1989; Dicken and } \\
\text { others, } 2005\end{array}$ \\
\hline Basin area in water & percent & Percent of basin area covered in surface water. & $\begin{array}{l}\text { Fenneman and Johnson, 1946; Mixon and others, 1989; Dicken and } \\
\text { others, } 2005\end{array}$ \\
\hline $\begin{array}{l}\text { Mean annual precipita- } \\
\text { tion }\end{array}$ & in. & $\begin{array}{l}\text { Mean annual precipitation falling on the basin, averaged } \\
\text { over the whole basin. }\end{array}$ & PRISM Climate Group, 2007; Paybins, 2008 \\
\hline $\begin{array}{l}\text { Mean January-Febru- } \\
\text { ary-March precipita- } \\
\text { tion }\end{array}$ & in. & $\begin{array}{l}\text { Mean January-February-March precipitation falling on } \\
\text { the basin, averaged over the whole basin. }\end{array}$ & PRISM Climate Group, 2007 \\
\hline $\begin{array}{l}\text { 2-year 24-hour precipi- } \\
\text { tation intensity }\end{array}$ & in. & $\begin{array}{l}\text { Basin average rainfall at the 24-hour 2-year recurrence } \\
\text { interval. }\end{array}$ & $\begin{array}{l}\text { National Oceanic and Atmospheric Administration, 2007; Paybins, } \\
2008\end{array}$ \\
\hline $\begin{array}{l}\text { Basin area with } 0 \text { per- } \\
\text { cent impervious } \\
\text { surface }\end{array}$ & percent & Percent of the basin coded as 0 percent impervious. & Yang and others, 2002; Homer and others, 2004 \\
\hline $\begin{array}{l}\text { Basin area with } \\
1-5 \text { percent impervi- } \\
\text { ous surface }\end{array}$ & percent & Percent of the basin coded as 1 to 5 percent impervious. & Yang and others, 2002; Homer and others, 2004 \\
\hline $\begin{array}{l}\text { Basin area with } \\
6-10 \text { percent imper- } \\
\text { vious surface }\end{array}$ & percent & $\begin{array}{l}\text { Percent of the basin coded as } 6 \text { to } 10 \text { percent impervi- } \\
\text { ous. }\end{array}$ & Yang and others, 2002; Homer and others, 2004 \\
\hline $\begin{array}{l}\text { Basin area with } \\
11-25 \text { percent imper- } \\
\text { vious surface }\end{array}$ & percent & $\begin{array}{l}\text { Percent of the basin coded as } 11 \text { to } 25 \text { percent impervi- } \\
\text { ous. }\end{array}$ & Yang and others, 2002; Homer and others, 2004 \\
\hline $\begin{array}{l}\text { Basin area with } \\
26-50 \text { percent imper- } \\
\text { vious surface }\end{array}$ & percent & $\begin{array}{l}\text { Percent of the basin coded as } 26 \text { to } 50 \text { percent impervi- } \\
\text { ous. }\end{array}$ & Yang and others, 2002; Homer and others, 2004 \\
\hline $\begin{array}{l}\text { Basin area with } \\
51-75 \text { percent imper- } \\
\text { vious surface }\end{array}$ & percent & $\begin{array}{l}\text { Percent of the basin coded as } 51 \text { to } 75 \text { percent impervi- } \\
\text { ous. }\end{array}$ & Yang and others, 2002; Homer and others, 2004 \\
\hline $\begin{array}{l}\text { Basin area with } \\
76-100 \text { percent im- } \\
\text { pervious surface }\end{array}$ & percent & $\begin{array}{l}\text { Percent of the basin coded as } 76 \text { to } 100 \text { percent impervi- } \\
\text { ous. }\end{array}$ & Yang and others, 2002; Homer and others, 2004 \\
\hline $\begin{array}{l}\text { Basin area with } 0 \text { per- } \\
\text { cent impervious } \\
\text { surface }\end{array}$ & $\mathrm{mi}^{2}$ & Area within the basin coded as 0 percent impervious. & Yang and others, 2002; Homer and others, 2004 \\
\hline $\begin{array}{l}\text { Basin area with } \\
1-5 \text { percent impervi- } \\
\text { ous surface }\end{array}$ & $\mathrm{mi}^{2}$ & $\begin{array}{l}\text { Area within the basin coded as } 1 \text { to } 5 \text { percent impervi- } \\
\text { ous. }\end{array}$ & Yang and others, 2002; Homer and others, 2004 \\
\hline $\begin{array}{l}\text { Basin area with } \\
6-10 \text { percent imper- } \\
\text { vious surface }\end{array}$ & $\mathrm{mi}^{2}$ & $\begin{array}{l}\text { Area within the basin coded as } 6 \text { to } 10 \text { percent impervi- } \\
\text { ous. }\end{array}$ & Yang and others, 2002; Homer and others, 2004 \\
\hline $\begin{array}{l}\text { Basin area with } \\
11-25 \text { percent imper- } \\
\text { vious surface }\end{array}$ & $\mathrm{mi}^{2}$ & $\begin{array}{l}\text { Area within the basin coded as } 11 \text { to } 25 \text { percent imper- } \\
\text { vious. }\end{array}$ & Yang and others, 2002; Homer and others, 2004 \\
\hline $\begin{array}{l}\text { Basin area with } \\
26-50 \text { percent imper- } \\
\text { vious surface }\end{array}$ & $\mathrm{mi}^{2}$ & $\begin{array}{l}\text { Area within the basin coded as } 26 \text { to } 50 \text { percent imper- } \\
\text { vious. }\end{array}$ & Yang and others, 2002; Homer and others, 2004 \\
\hline $\begin{array}{l}\text { Basin area with } \\
51-75 \text { percent imper- } \\
\text { vious surface }\end{array}$ & $\mathrm{mi}^{2}$ & $\begin{array}{l}\text { Area within the basin coded as } 51 \text { to } 75 \text { percent imper- } \\
\text { vious. }\end{array}$ & Yang and others, 2002; Homer and others, 2004 \\
\hline $\begin{array}{l}\text { Basin area with } \\
76-100 \text { percent im- } \\
\text { pervious surface }\end{array}$ & $\mathrm{mi}^{2}$ & $\begin{array}{l}\text { Area within the basin coded as } 76 \text { to } 100 \text { percent } \\
\text { impervious. }\end{array}$ & Yang and others, 2002; Homer and others, 2004 \\
\hline
\end{tabular}




\section{Model Development}

Exploratory analyses of all computed P-percent chance 1-, 4-, 7-, and 30-day averaged low flows and potential explanatory variables (basin characteristics) were performed prior to developing candidate regression models, using statistical software, JMP ${ }^{\circledR}$ version $8 .{ }^{3}$ Sites with 50 percent or more of their drainage area within a region were included in developing that region's regression equations, with the exception of the Coastal Plain region in which all sites with 5 percent or more of their land area within the region were included in developing the region's regression equations. Scatter plots showing relations between pairs of basin characteristics were evaluated along with basic descriptive statistics to (1) identify explanatory variable pairs that are highly correlated with one another so that they may be evaluated and possibly removed from the selection dataset and (2) determine candidate explanatory variable, response variable pairs that are highly correlated with potentially significant explanatory power. In some instances, one or both variables in an explanatory variable, response variable pair were mathematically transformed to potentially enhance their relation and statistical power when part of a linear regression model. Depending on the shape of each scatter plot relation, possible transformations of the $\mathrm{X}$ variable included $\log X, \sqrt{X}, X^{2}$, and $X^{3}$, and possible transformations of the $\mathrm{Y}$ variable included $\log Y, \sqrt{Y}, Y^{2}$, and $Y^{3}$, as suggested by "Tukey's bulging rule" (Mosteller and Tukey, 1977). Exploratory statistical investigation and comparison of the 312 candidate explanatory basin characteristics associated with each P-percent chance 1-, 4-, 7-, and 30-day averaged low-flow value proceeded iteratively until each candidate variable, low-flow value $x$-y pair was vetted for possible explanatory power.

Candidate regional regression models were developed following an iterative approach. For each region, and for each 1-, 4-, 7-, and 30-day averaged low-flow response variable, forward-, backward-, and mixed-stepwise regressions were used to identify combinations of basin characteristics with likely explanatory power. A list of all possible 1-, 2-, and 3-parameter candidate models was prepared for each 1-, 4-, 7-, and 30-day averaged P-percent chance low-flow response variable. The list of candidate models was sorted by the number of explanatory variables in each model. Then, candidate models in each sub-list were evaluated using three metrics- the coefficient of determination (R-square), the root mean square error (RMSE), and Akaike's information criterion (AIC), modified with a second-order correction for small sample sizes and identified as AICc, (Burnham and Anderson, 2002). The most reasonable 1-, 2-, and 3-parameter models for each 1-, 4-, 7-, and 30-day averaged P-percent chance low flow in each region were chosen as final candidates for regional regression. Final 1-, 2-, and 3-parameter regional regression models were prepared using statistical software (JMP ${ }^{\circledR}$ version 8). Explanatory variables for any 2- and 3-parameter models were

${ }^{3}$ SAS Institute Inc., 2009, Cary, North Carolina. carefully chosen to ensure that each variable in the model contributed adequate explanatory power and to avoid instances of collinearity, autocorrelation, or excessive variance inflation. Regional regression models were evaluated and modified iteratively. Final models were then selected. Coefficients of final models were specified using the weighted least squares (WLS) option of the Weighted-Multiple-Linear Regression Program (WREG, version 1.01; Eng and others, 2009). Preference was given to regional regression models with explanatory variables that are easily determined and understood. Models with little explanatory power and high standard errors were not reported.

\section{Model Verification and Diagnostics}

Evaluation of candidate models using R-square, RMSE, and AICc provided insights into the most appropriate candidate model choices for each 1-, 4-, 7-, and 30-day averaged P-percent chance low-flow response variable in each region. The R-square value indicated the proportion of variability in each relation that was accounted for by the statistical model - in this case, a linear regression model. R-square values approaching 1 suggested increased explanatory power. The RMSE value indicated the differences between values predicted by each model and the values actually observed or measured. The RMSE helped to aggregate individual residual differences into a single measure of predictive power. To assist in choosing among candidate models in each region, plots were constructed identifying each candidate model by the number of model parameters (x-axis) and RMSE value (y-axes), providing a spatial representation of increased or decreased RMSE relative to the number of model terms. The AICc value indicated the goodness of fit of each regression model, relative to other candidate models in the list, providing a tool for model selection. AICc values are grounded in the concept of entropy, offering a relative measure of the information lost when a given model is used to describe reality. AICc describes the difference between model bias and model variance, or the tradeoff between model precision and model complexity. Several competing models may be ranked by their AICc values. Lower AICc values were considered better than higher values.

Leverage plots (Sall, 1990), also known as "partialregression residual leverage plots" (Belsley and others, 1980) or "added variable plots" (Cook and Weisberg, 1982), were used to further investigate and screen candidate regional regression models. Leverage plots allow one to view the significance of each model parameter in the candidate regression model within the context of the larger model. The effect of a model parameter on the larger model is displayed on the leverage plot by comparing the sum of squared residuals of the model to the sum of squared residuals of the model with the effect of interest removed. Residual errors that are smaller when the effect of a particular parameter is included in the model help confirm that the effect contributes significantly 
to the model fit. The leverage plot graphically displays this potential significance for each candidate explanatory variable, showing for each point in the model what the residual would be with and without the effect in the model. In the leverage plot, the distance from a point to the line of fit describes the actual residual. The distance from a point to the horizontal line of the mean describes the potential residual error if the effect were not part of the model. In other words, the mean line of the leverage plot represents the model if the value of the parameter effect were constrained to zero. The idea is to determine if the line of fit on the leverage plot for each explanatory variable carries each point on the plot significantly better than does the horizontal line of the mean shown on the plot. Leverage plots were used to identify (1) regression variables with significant explanatory power, (2) regression variables with borderline or insignificant explanatory power, and (3) regression variables exhibiting significant collinearity within the model (fig. 2).

Analyses of leverage plots for each potential explanatory variable in a candidate regression model afforded the opportunity to see the characteristics of each candidate variable, the influential strength of the variable, and its consequences within the larger model. The picture provided by each leverage plot enabled a thorough, visual vetting of individual candidate model variables and a measure of confidence in variable selection that could not be obtained from non-graphical indices of collinearity and variable inflation, preparing a means to construct robust regional regressions. A leverage plot was constructed and evaluated for each model parameter in each candidate regional regression model. Models containing explanatory variables with significant explanatory power, limited parameter counts, and limited collinearity were preferred as final candidates.

Explanatory variables associated with the best candidate models were chosen for inclusion in final candidate singleparameter and multi-parameter regional regression models. Preference was given to explanatory variables that are easily measured and understood.

Final models were specified using WLS regression (Eng and others, 2009). Weights were formed as described in the Weighted-Multiple-Linear Regression Program (WREG, version 1.01). Candidate regional regressions and their associated leverage plots were carefully evaluated to avoid the effects of potential cross correlation between sites and excessive variability in low flows at streamgaging stations.

Because the length of streamflow record varies among streamgages, the precision of streamflow estimates also varies. Different streamflow records have different variances. Concurrent flows observed at different gages in a region can yield cross correlations. If these correlations are not accounted for in a regional analysis, regression parameters may be less precise, and estimators of precision may be less accurate (Eng and others, 2009).

WLS analyses account for cross correlations among characteristics. Weights are formed using the period of record and the variance of the response variable annual time
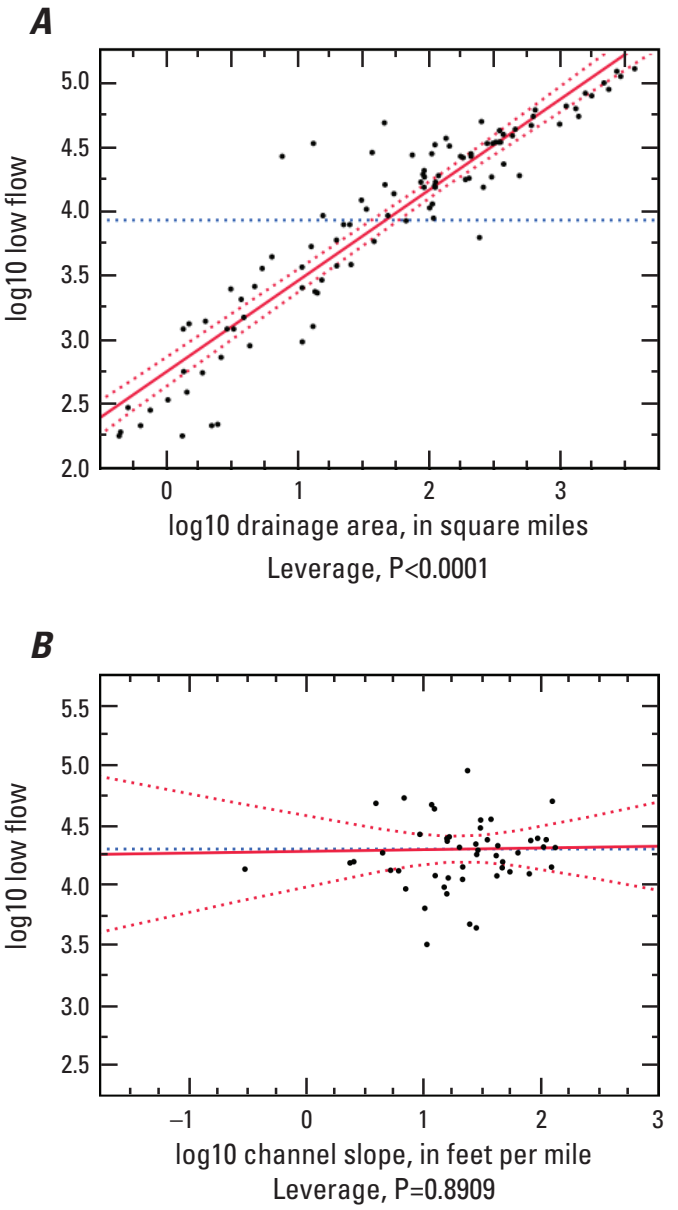

C

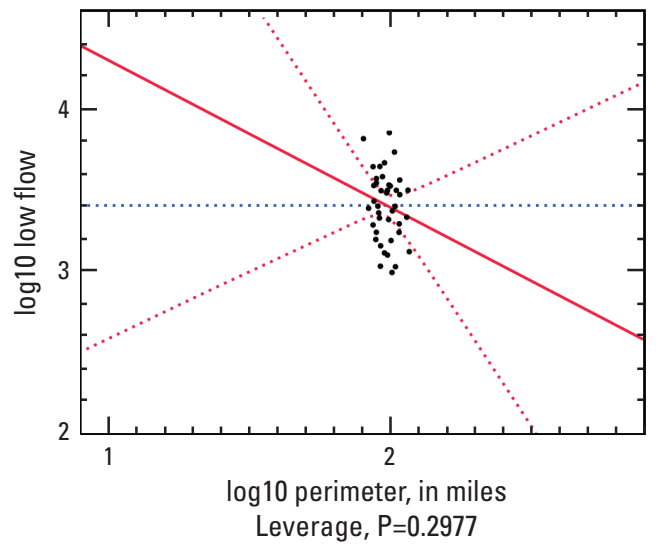

Figure 2. Example leverage plots showing $(A)$ significant explanatory power, $(B)$ insignificant explanatory power, and (C) evidence of collinearity. The solid red lines represent the significance of each explanatory model parameter, shown on the $x$-axis, within the context of the larger model. The dashed red lines represent the confidence interval of the significance of each explanatory model parameter. The dashed blue lines represent the horizontal line of the mean, describing the larger model if the effect of each explanatory model parameter were constrained to zero. The idea behind each leverage plot is to determine if the line of fit for each potential explanatory model variable carries each point on the plot significantly better than does the horizontal line of the mean shown on the plot. 
series. The series of annual 1-, 4-, 7-, and 30-day averaged P-percent chance low flows at streamgaging stations and the geographic distances between streamgages are examined to help determine the degree of potential correlation between sites. Weights are assigned to account for variability. Sites exhibiting potentially cross-correlated, concurrent low flows are given less weight than other sites. Pseudo R-square is reported for each WLS regression model. A metric in the style of the R-square commonly reported as part of ordinary least squares regression, pseudo R-square is designed specifically to evaluate the iterative models developed using WREG.

The average variance of prediction (AVP; Stedinger and Tasker, 1985; Tasker and Stedinger, 1989) is a helpful indication of the average error of a regression. The AVP may be represented by one of two equations. The first option is

$$
A V P=\sigma_{i}^{T}+\left(\frac{1}{n}\right) \sum_{n=1}^{n} x_{1}\left(X^{T} \wedge X\right)^{-1} X_{i}^{T}
$$

where

$$
\begin{aligned}
& A V P=\text { the average variance of prediction, } \\
& \sigma_{i}^{T}=\text { the model error variance, } \\
& n=\text { the number of streamgaging stations in the } \\
& \text { regression model, } \\
& x=\text { the vector containing the basin attributes of } \\
& \text { the } \mathrm{i}^{\text {th }} \text { station augmented by the value of } \\
& \text { one, } \\
& X=\text { the matrix of all basin attributes at all } \\
& \text { streamgaging stations in the regression } \\
& \text { augmented by a column of ones, } \\
& \wedge=\text { the weighting matrix (Tasker and Stedinger, } \\
& \text { 1989), } \\
& T=\text { superscript indicating taking the transpose of } \\
& \text { a matrix, and } \\
& { }^{-1}=\text { superscript indicating taking the inverse of a } \\
& \text { matrix. }
\end{aligned}
$$

The second option is

$$
A V P=\text { error }_{m}+\text { error }_{t}
$$

where

$$
\begin{aligned}
\text { AVP } & =\text { the average variance of prediction, } \\
\text { error }_{m} & =\text { model error, and } \\
\text { error }_{t} & =\text { time sampling error. }
\end{aligned}
$$

The AVP may be used to provide an estimate of errors that may be associated with the use of a regression model to estimate flow statistics at an ungaged site. An important consideration is that the AVP metric assumes that basin characteristics at the ungaged location are similar to those used to develop the model.
The average standard error of prediction in percent, $S_{p}$, is used in this report to express the AVP as a percentage. $S_{p}{ }_{p}$ is computed from the AVP (Aitchison and Brown, 1957) and modified for use with common logarithms as follows:

$$
S_{p}=100 \sqrt{E X P\left[\sigma^{2} \cdot \ln (10)^{2}\right]}-1,
$$

where:

$$
\begin{gathered}
S_{p}=\text { the average standard error of prediction, in } \\
\text { percent; and } \\
\sigma^{2}=\text { the average variance of prediction. }
\end{gathered}
$$

Regionalization yielded well-correlated low-flow regression equations in each of the six regions using computed low-flow statistics from sites listed in table 1 and selected basin characteristics. Candidate regional regression equations describing 1-, 4-, 7-, and 30-day average low flows in the Mesozoic Basins yielded the highest median R-square values of $0.80,0.81,0.82$, and 0.86 and lowest median root mean square error values of $0.48,0.48,0.47$, and 0.40 , respectively. Candidate regional regression equations describing 1-, 4-, 7-, and 30-day average low flows in the Blue Ridge yielded median R-square of $0.74,0.79,0.79$, and 0.83 and median root mean square error of $0.53,0.47,0.48$, and 0.41 , respectively. Candidate regional regression equations describing 1-, 4-, 7-, and 30-day average low flows in the Valley and Ridge yielded median R-square of $0.76,0.78,0.77$, and 0.80 and median root mean square error of $0.40,0.39,0.39$, and 0.36 , respectively. Candidate regional regression equations describing 1-, 4-, 7-, and 30-day average low flow in the Piedmont, excluding the Mesozoic Basins located within the Piedmont, yielded median R-square of $0.65,0.66,0.68$, and 0.70 and median root mean square error of $0.67,0.66,0.65$, and 0.61 , respectively. Candidate regional regression equations describing 1-, 4-, 7-, and 30-day average low flow in the Coastal Plain yielded median R-square of $0.58,0.59,0.65$, and 0.65 and median root mean square error of $0.61,0.63,0.55$, and 0.53 , respectively. Candidate regional regression equations describing 1-, 4-, 7-, and 30-day average low flows in the Appalachian Plateaus yielded median R-square of $0.49,0.59,0.57$, and 0.68 and median root mean square error of $0.45,0.32,0.33$, and 0.25 , respectively. Regional regression equations are found in table 10 . 
Table 10. Regional regression equations for estimating low flows of streams in Virginia.

[DA, basin drainage area in square miles]

\begin{tabular}{|c|c|c|c|}
\hline & Pseudo R-square $^{a}$ & $\begin{array}{l}\text { Average standard } \\
\text { error of } \\
\text { prediction }^{\mathrm{a}} \\
\text { (percent) }^{\text {pont }}\end{array}$ & $\begin{array}{c}\text { Standard model } \\
\text { error }^{\mathrm{a}} \\
\text { (percent) }^{\text {percent }}\end{array}$ \\
\hline $\log 10 \operatorname{LF} 1$ Day $(0.9)=-0.857+0.961 \cdot \log 10(\mathrm{DA})$ & 0.88 & 71 & 66 \\
\hline $\log 10 \operatorname{LF} 1$ Day $(0.8)=-1.021+0.952 \cdot \log 10(\mathrm{DA})$ & 0.82 & 94 & 88 \\
\hline $\log 10 \operatorname{LF} 1 \operatorname{Day}(0.7)=-1.177+0.954 \cdot \log 10(\mathrm{DA})$ & 0.77 & 118 & 110 \\
\hline $\log 10 \operatorname{LF} 1 \operatorname{Day}(0.5)=-1.482+0.96 \cdot \log 10(\mathrm{DA})$ & 0.65 & 194 & 176 \\
\hline $\log 10 \operatorname{LF} 1$ Day $(0.4)=-1.692+0.964 \cdot \log 10(\mathrm{DA})$ & 0.50 & 396 & 342 \\
\hline $\log 10 \operatorname{LF} 4$ Day $(0.9)=-0.601+0.89 \cdot \log 10(\mathrm{DA})$ & 0.89 & 62 & 60 \\
\hline $\log 10 \operatorname{LF} 4$ Day $(0.8)=-0.747+0.875 \cdot \log 10(\mathrm{DA})$ & 0.85 & 77 & 74 \\
\hline $\log 10 \operatorname{LF} 4 \operatorname{Day}(0.7)=-0.883+0.87 \cdot \log 10(\mathrm{DA})$ & 0.81 & 94 & 90 \\
\hline $\log 10 \operatorname{LF} 4 \operatorname{Day}(0.6)=-1.013+0.867 \cdot \log 10(\mathrm{DA})$ & 0.76 & 113 & 108 \\
\hline $\log 10 \operatorname{LF} 7 D a y(0.8)=-0.695+0.874 \cdot \log 10(\mathrm{DA})$ & 0.87 & 70 & 67 \\
\hline $\log 10 \operatorname{LF} 7 D a y(0.7)=-0.83+0.87 \cdot \log 10(\mathrm{DA})$ & 0.83 & 85 & 81 \\
\hline $\log 10 \operatorname{LF} 7 \operatorname{Day}(0.6)=-0.966+0.869 \cdot \log 10(\mathrm{DA})$ & 0.79 & 102 & 98 \\
\hline $\log 10 \operatorname{LF} 7 D a y(0.5)=-1.106+0.868 \cdot \log 10(D A)$ & 0.73 & 127 & 121 \\
\hline $\log 10 \operatorname{LF} 7 \operatorname{Day}(0.4)=-1.255+0.859 \cdot \log 10(\mathrm{DA})$ & 0.64 & 183 & 173 \\
\hline $\log 10 \operatorname{LF} 30 \operatorname{Day}(0.9)=-0.335+0.917 \cdot \log 10(\mathrm{DA})$ & 0.96 & 35 & 33 \\
\hline $\log 10 \operatorname{LF} 30 \operatorname{Day}(0.8)=-0.461+0.897 \cdot \log 10(\mathrm{DA})$ & 0.95 & 41 & 40 \\
\hline $\log 10 \operatorname{LF} 30 \operatorname{Day}(0.7)=-0.578+0.887 \cdot \log 10(\mathrm{DA})$ & 0.92 & 53 & 51 \\
\hline $\log 10 \operatorname{LF} 30 \operatorname{Day}(0.6)=-0.686+0.876 \cdot \log 10(\mathrm{DA})$ & 0.88 & 66 & 64 \\
\hline $\log 10 \operatorname{LF} 30 \operatorname{Day}(0.5)=-0.8+0.867 \cdot \log 10(\mathrm{DA})$ & 0.83 & 84 & 80 \\
\hline $\log 10 \operatorname{LF} 30 \operatorname{Day}(0.4)=-0.93+0.858 \cdot \log 10(\mathrm{DA})$ & 0.77 & 110 & 105 \\
\hline $\log 10 \operatorname{LF} 4 \operatorname{Day}(0.9)=-0.353+0.86 \cdot \log 10(\mathrm{DA})$ & 0.71 & 130 & 126 \\
\hline $\log 10 \mathrm{LF} 4 \mathrm{Day}(0.8)=-0.477+0.868 \cdot \log 10(\mathrm{DA})$ & 0.68 & 148 & 142 \\
\hline $\log 10 \operatorname{LF} 4$ Day $(0.7)=-0.588+0.878 \cdot \log 10(\mathrm{DA})$ & 0.65 & 167 & 160 \\
\hline $\log 10 \operatorname{LF} 4$ Day $(0.6)=-0.705+0.892 \cdot \log 10(\mathrm{DA})$ & 0.63 & 189 & 181 \\
\hline $\log 10 \operatorname{LF} 4$ Day $(0.5)=-0.84+0.911 \cdot \log 10(\mathrm{DA})$ & 0.60 & 220 & 209 \\
\hline $\log 10 \operatorname{LF} 4 \operatorname{Day}(0.4)=-1.03+0.947 \cdot \log 10(\mathrm{DA})$ & 0.57 & 274 & 259 \\
\hline $\log 10 \operatorname{LF} 7 \operatorname{Day}(0.9)=-0.252+0.857 \cdot \log 10(\mathrm{DA})$ & 0.78 & 101 & 98 \\
\hline $\log 10 \operatorname{LF} 7 D a y(0.8)=-0.38+0.869 \cdot \log 10(\mathrm{DA})$ & 0.75 & 113 & 109 \\
\hline $\log 10 \operatorname{LF} 7 D a y(0.7)=-0.483+0.878 \cdot \log 10(\mathrm{DA})$ & 0.73 & 123 & 119 \\
\hline $\log 10 \operatorname{LF} 7 D a y(0.6)=-0.583+0.888 \cdot \log 10(\mathrm{DA})$ & 0.72 & 134 & 130 \\
\hline $\log 10 \operatorname{LF} 7 \operatorname{Day}(0.5)=-0.683+0.898 \cdot \log 10(\mathrm{DA})$ & 0.70 & 146 & 141 \\
\hline $\log 10 \operatorname{LF} 7 D a y(0.4)=-0.796+0.911 \cdot \log 10(\mathrm{DA})$ & 0.69 & 159 & 153 \\
\hline $\log 10 \operatorname{LF} 7$ Day $(0.3)=-0.926+0.924 \cdot \log 10(\mathrm{DA})$ & 0.67 & 175 & 169 \\
\hline $\log 10 \operatorname{LF} 7 \operatorname{Day}(0.2)=-1.102+0.945 \cdot \log 10(\mathrm{DA})$ & 0.65 & 199 & 190 \\
\hline $\log 10 \operatorname{LF} 7 \operatorname{Day}(0.1)=-1.385+0.981 \cdot \log 10(\mathrm{DA})$ & 0.63 & 242 & 231 \\
\hline $\log 10 \operatorname{LF} 7 \operatorname{Day}(0.05)=-1.654+1.015 \cdot \log 10(\mathrm{DA})$ & 0.60 & 302 & 286 \\
\hline $\log 10 \operatorname{LF} 30 \operatorname{Day}(0.9)=-0.336+0.944 \cdot \log 10(\mathrm{DA})$ & 0.88 & 82 & 80 \\
\hline $\log 10 \operatorname{LF} 30 \operatorname{Day}(0.8)=-0.514+0.97 \cdot \log 10(\mathrm{DA})$ & 0.87 & 93 & 91 \\
\hline $\log 10 \operatorname{LF} 30 \operatorname{Day}(0.7)=-0.667+0.994 \cdot \log 10(\mathrm{DA})$ & 0.85 & 106 & 103 \\
\hline
\end{tabular}


Table 10. Regional regression equations for estimating low flows of streams in Virginia._Continued

[DA, basin drainage area in square miles]

\begin{tabular}{|c|c|c|c|}
\hline & Pseudo R-square ${ }^{a}$ & $\begin{array}{l}\text { Average standard } \\
\text { error of } \\
\text { prediction }^{\mathrm{a}} \\
\text { (percent) }\end{array}$ & $\begin{array}{c}\text { Standard model } \\
\text { error }^{\mathrm{a}} \\
\text { (percent) }^{\text {percent }}\end{array}$ \\
\hline \multicolumn{4}{|c|}{ Virginia basins in the Piedmont region, except those within the Mesozoic Basins (Continued) } \\
\hline $\log 10 \mathrm{LF} 30 \mathrm{Day}(0.6)=-0.807+1.017 \cdot \log 10(\mathrm{DA})$ & 0.84 & 119 & 116 \\
\hline $\log 10 \operatorname{LF} 30 \mathrm{Day}(0.5)=-0.963+1.047 \cdot \log 10(\mathrm{DA})$ & 0.82 & 136 & 133 \\
\hline $\log 10 \operatorname{LF} 30 \mathrm{Day}(0.4)=-1.101+1.065 \cdot \log 10(\mathrm{DA})$ & 0.80 & 156 & 152 \\
\hline $\log 10 \operatorname{LF} 1 \operatorname{Day}(0.9)=-0.705+1.107 \cdot \log 10(\mathrm{DA})$ & 0.93 & 44 & 43 \\
\hline $\log 10 \operatorname{LF} 1 \operatorname{Day}(0.8)=-0.881+1.137 \cdot \log 10(\mathrm{DA})$ & 0.91 & 54 & 53 \\
\hline $\log 10 \operatorname{LF} 1 \operatorname{Day}(0.7)=-1.025+1.162 \cdot \log 10(\mathrm{DA})$ & 0.89 & 63 & 61 \\
\hline $\log 10 \operatorname{LF} 1 \operatorname{Day}(0.6)=-1.162+1.188 \cdot \log 10(\mathrm{DA})$ & 0.87 & 72 & 70 \\
\hline $\log 10 \operatorname{LF} 1 \operatorname{Day}(0.5)=-1.305+1.215 \cdot \log 10(\mathrm{DA})$ & 0.85 & 81 & 79 \\
\hline $\log 10 \operatorname{LF} 4 \operatorname{Day}(0.9)=-0.689+1.118 \cdot \log 10(\mathrm{DA})$ & 0.93 & 45 & 43 \\
\hline $\log 10 \operatorname{LF} 4 \operatorname{Day}(0.8)=-0.858+1.148 \cdot \log 10(\mathrm{DA})$ & 0.91 & 55 & 53 \\
\hline $\log 10 \operatorname{LF} 4 \operatorname{Day}(0.7)=-0.998+1.174 \cdot \log 10(\mathrm{DA})$ & 0.89 & 64 & 62 \\
\hline $\log 10 \operatorname{LF} 4 \operatorname{Day}(0.6)=-1.134+1.201 \cdot \log 10(\mathrm{DA})$ & 0.87 & 73 & 71 \\
\hline $\log 10 \operatorname{LF} 4 \operatorname{Day}(0.5)=-1.274+1.229 \cdot \log 10(\mathrm{DA})$ & 0.85 & 83 & 80 \\
\hline $\log 10 \operatorname{LF} 4$ Day $(0.4)=-1.427+1.26 \cdot \log 10(\mathrm{DA})$ & 0.83 & 94 & 91 \\
\hline $\log 10 \operatorname{LF} 4 \operatorname{Day}(0.3)=-1.611+1.3 \cdot \log 10(\mathrm{DA})$ & 0.81 & 108 & 104 \\
\hline $\log 10 \operatorname{LF} 4 \operatorname{Day}(0.2)=-1.854+1.353 \cdot \log 10(\mathrm{DA})$ & 0.78 & 128 & 124 \\
\hline $\log 10 \operatorname{LF} 4$ Day $(0.1)=-2.25+1.445 \cdot \log 10(\mathrm{DA})$ & 0.75 & 169 & 162 \\
\hline $\log 10 \mathrm{LF} 4 \mathrm{Day}(0.05)=-2.682+1.554 \cdot \log 10(\mathrm{DA})$ & 0.72 & 228 & 216 \\
\hline $\log 10 \operatorname{LF} 7 \operatorname{Day}(0.9)=-0.657+1.119 \cdot \log 10(\mathrm{DA})$ & 0.93 & 44 & 43 \\
\hline $\log 10 \operatorname{LF} 7 \operatorname{Day}(0.1)=-2.199+1.441 \cdot \log 10(\mathrm{DA})$ & 0.75 & 165 & 158 \\
\hline $\log 10 \operatorname{LF} 7 D a y(0.05)=-2.589+1.535 \cdot \log 10(\mathrm{DA})$ & 0.72 & 217 & 206 \\
\hline $\log 10 \operatorname{LF} 30 \operatorname{Day}(0.9)=-0.489+1.096 \cdot \log 10(\mathrm{DA})$ & 0.95 & 35 & 34 \\
\hline $\log 10 \operatorname{LF} 30$ Day $(0.8)=-0.661+1.126 \cdot \log 10(\mathrm{DA})$ & 0.93 & 43 & 42 \\
\hline $\log 10 \operatorname{LF} 30 \operatorname{Day}(0.7)=-0.798+1.151 \cdot \log 10(\mathrm{DA})$ & 0.92 & 51 & 49 \\
\hline $\log 10 \operatorname{LF} 30$ Day $(0.6)=-0.924+1.174 \cdot \log 10(\mathrm{DA})$ & 0.90 & 58 & 57 \\
\hline $\log 10 \operatorname{LF} 30 \operatorname{Day}(0.5)=-1.049+1.198 \cdot \log 10(\mathrm{DA})$ & 0.88 & 66 & 64 \\
\hline $\log 10 \operatorname{LF} 30 \mathrm{Day}(0.4)=-1.184+1.225 \cdot \log 10(\mathrm{DA})$ & 0.87 & 75 & 72 \\
\hline $\log 10 \operatorname{LF} 30 \operatorname{Day}(0.3)=-1.34+1.258 \cdot \log 10(\mathrm{DA})$ & 0.85 & 85 & 83 \\
\hline $\log 10 \operatorname{LF} 30 \operatorname{Day}(0.2)=-1.533+1.298 \cdot \log 10(\mathrm{DA})$ & 0.82 & 100 & 96 \\
\hline $\log 10 \operatorname{LF} 30 \operatorname{Day}(0.1)=-1.829+1.361 \cdot \log 10(\mathrm{DA})$ & 0.79 & 126 & 121 \\
\hline $\log 10 \operatorname{LF} 30 \mathrm{Day}(0.05)=-2.111+1.425 \cdot \log 10(\mathrm{DA})$ & 0.76 & 156 & 149 \\
\hline $\log 10 \operatorname{LF} 30$ Day $(0.02)=-2.462+1.508 \cdot \log 10(\mathrm{DA})$ & 0.72 & 206 & 196 \\
\hline $\log 10 \operatorname{LF} 30$ Day $(0.01)=-2.703+1.564 \cdot \log 10(\mathrm{DA})$ & 0.70 & 252 & 238 \\
\hline $\log 10 \mathrm{LF} 30 \operatorname{Day}(0.005)=-2.855+1.589 \cdot \log 10(\mathrm{DA})$ & 0.68 & 294 & 277 \\
\hline \multicolumn{4}{|c|}{ Virginia basins in the Valley and Ridge region } \\
\hline $\log 10 \operatorname{LF} 1 \operatorname{Day}(0.9)=-0.794+1.064 \cdot \log 10(\mathrm{DA})$ & 0.88 & 54 & 52 \\
\hline $\log 10 \mathrm{LF} 1 \mathrm{Day}(0.8)=-0.907+1.081 \cdot \log 10(\mathrm{DA})$ & 0.86 & 60 & 58 \\
\hline $\log 10 \operatorname{LF} 1 \operatorname{Day}(0.7)=-0.993+1.094 \cdot \log 10(\mathrm{DA})$ & 0.85 & 65 & 63 \\
\hline $\log 10 \operatorname{LF} 1 \operatorname{Day}(0.6)=-1.071+1.106 \cdot \log 10(\mathrm{DA})$ & 0.84 & 69 & 68 \\
\hline
\end{tabular}


Table 10. Regional regression equations for estimating low flows of streams in Virginia.-Continued

[DA, basin drainage area in square miles]

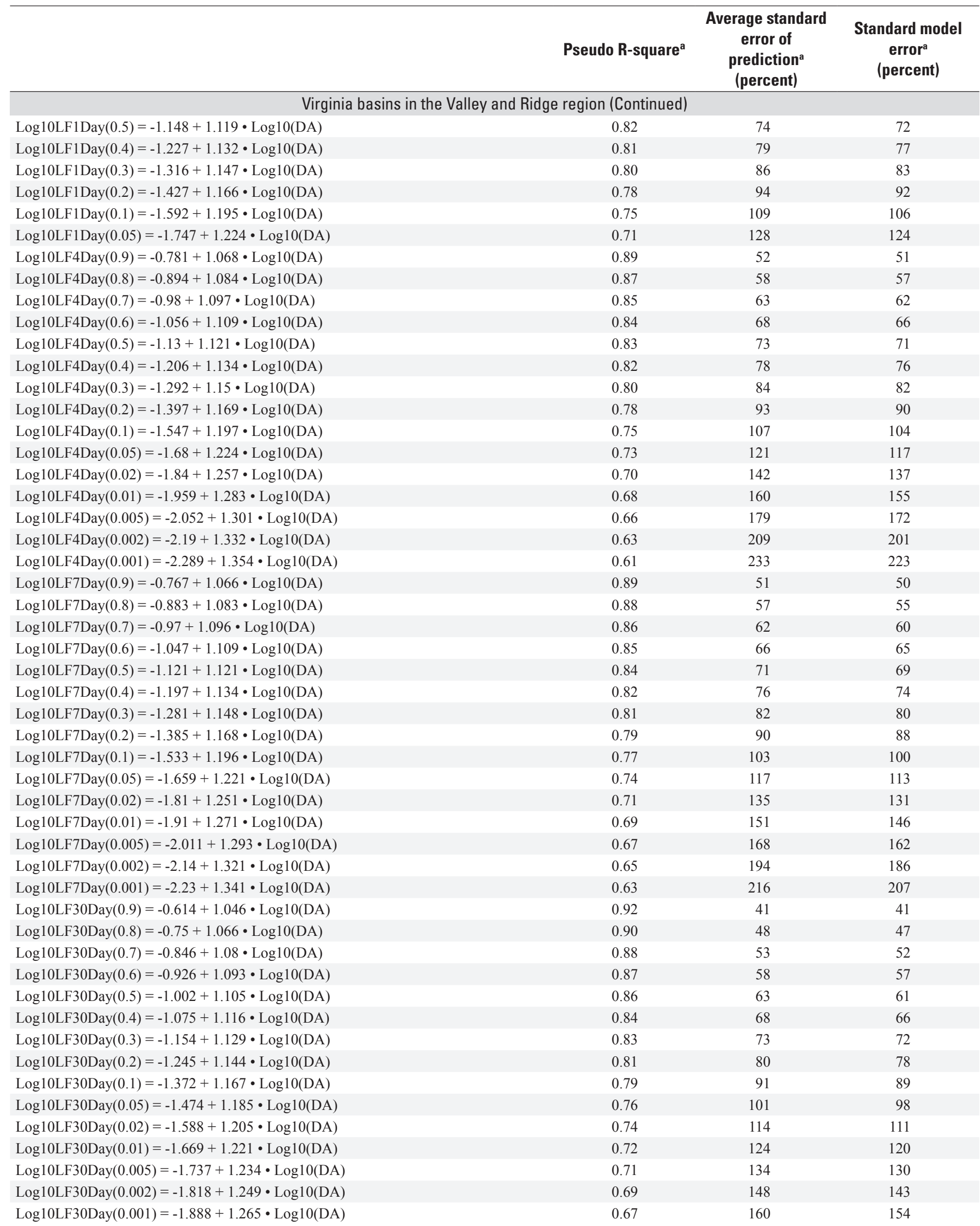


Table 10. Regional regression equations for estimating low flows of streams in Virginia._Continued

[DA, basin drainage area in square miles]

\begin{tabular}{|c|c|c|c|}
\hline & Pseudo R-square $^{a}$ & $\begin{array}{l}\text { Average standard } \\
\text { error of } \\
\text { prediction }^{\mathrm{a}} \\
\text { (percent) }^{\text {ped }}\end{array}$ & $\begin{array}{c}\text { Standard model } \\
\text { error }^{\mathrm{a}} \\
\text { (percent) }\end{array}$ \\
\hline $\log 10 \operatorname{LF} 1 \operatorname{Day}(0.9)=-0.413+0.836 \cdot \log 10(\mathrm{DA})$ & 0.91 & 29 & 26 \\
\hline $\log 10 \operatorname{LF} 1 \operatorname{Day}(0.8)=-0.557+0.847 \cdot \log 10(\mathrm{DA})$ & 0.86 & 36 & 33 \\
\hline $\log 10 \mathrm{LF} 1 \mathrm{Day}(0.7)=-0.68+0.859 \cdot \log 10(\mathrm{DA})$ & 0.82 & 43 & 40 \\
\hline $\log 10 \operatorname{LF} 1$ Day $(0.5)=-0.933+0.894 \cdot \log 10(\mathrm{DA})$ & 0.72 & 60 & 55 \\
\hline $\log 10 \operatorname{LF} 1 \operatorname{Day}(0.4)=-1.079+0.917 \cdot \log 10(\mathrm{DA})$ & 0.68 & 70 & 64 \\
\hline $\log 10 \operatorname{LF} 1 \operatorname{Day}(0.3)=-1.264+0.951 \cdot \log 10(\mathrm{DA})$ & 0.63 & 84 & 76 \\
\hline $\log 10 \operatorname{LF} 1 \mathrm{Day}(0.2)=-1.516+1.002 \cdot \log 10(\mathrm{DA})$ & 0.57 & 106 & 96 \\
\hline $\log 10 \operatorname{LF} 1 \operatorname{Day}(0.1)=-2.104+1.158 \cdot \log 10(\mathrm{DA})$ & 0.44 & 200 & 174 \\
\hline $\log 10 \mathrm{LF} 4 \mathrm{Day}(0.9)=-0.434+0.864 \cdot \log 10(\mathrm{DA})$ & 0.91 & 30 & 27 \\
\hline $\log 10 \operatorname{LF} 4 \operatorname{Day}(0.5)=-0.882+0.89 \cdot \log 10(\mathrm{DA})$ & 0.73 & 60 & 55 \\
\hline $\log 10 \operatorname{LF} 4 \mathrm{Day}(0.4)=-1.015+0.907 \cdot \log 10(\mathrm{DA})$ & 0.69 & 70 & 63 \\
\hline $\log 10 \operatorname{LF} 4 \operatorname{Day}(0.3)=-1.179+0.933 \cdot \log 10(\mathrm{DA})$ & 0.64 & 82 & 75 \\
\hline $\log 10 \operatorname{LF} 4$ Day $(0.2)=-1.393+0.967 \cdot \log 10(\mathrm{DA})$ & 0.58 & 101 & 91 \\
\hline $\log 10 \operatorname{LF} 4 \operatorname{Day}(0.1)=-1.758+1.037 \cdot \log 10(\mathrm{DA})$ & 0.51 & 139 & 122 \\
\hline $\log 10 \operatorname{LF} 4 \operatorname{Day}(0.05)=-2.138+1.121 \cdot \log 10(\mathrm{DA})$ & 0.46 & 190 & 163 \\
\hline $\log 10 \mathrm{LF} 4 \mathrm{Day}(0.02)=-2.573+1.212 \cdot \log 10(\mathrm{DA})$ & 0.41 & 288 & 238 \\
\hline $\log 10 \operatorname{LF} 4 \operatorname{Day}(0.01)=-3.074+1.356 \cdot \log 10(\mathrm{DA})$ & 0.39 & 433 & 342 \\
\hline $\log 10 \operatorname{LF} 7 D a y(0.9)=-0.461+0.887 \cdot \log 10(\mathrm{DA})$ & 0.92 & 30 & 27 \\
\hline $\log 10 \operatorname{LF} 7 \operatorname{Day}(0.8)=-0.556+0.878 \cdot \log 10(\mathrm{DA})$ & 0.87 & 37 & 33 \\
\hline $\log 10 \operatorname{LF} 7 \operatorname{Day}(0.7)=-0.643+0.875 \cdot \log 10(\mathrm{DA})$ & 0.83 & 43 & 39 \\
\hline $\log 10 \operatorname{LF} 7$ Day $(0.02)=-2.301+1.117 \cdot \log 10(\mathrm{DA})$ & 0.39 & 256 & 214 \\
\hline $\log 10 \operatorname{LF} 7 \operatorname{Day}(0.01)=-2.583+1.17 \cdot \log 10(\mathrm{DA})$ & 0.35 & 353 & 285 \\
\hline $\log 10 \operatorname{LF} 7$ Day $(0.005)=-2.87+1.227 \cdot \log 10(\mathrm{DA})$ & 0.32 & 505 & 390 \\
\hline $\log 10 \operatorname{LF} 30 \operatorname{Day}(0.9)=-0.505+0.986 \cdot \log 10(\mathrm{DA})$ & 0.97 & 21 & 19 \\
\hline $\log 10 \mathrm{LF} 30 \operatorname{Day}(0.8)=-0.57+0.962 \cdot \log 10(\mathrm{DA})$ & 0.95 & 25 & 23 \\
\hline $\log 10 \operatorname{LF} 30 \operatorname{Day}(0.7)=-0.624+0.944 \cdot \log 10(\mathrm{DA})$ & 0.92 & 30 & 27 \\
\hline $\log 10 \operatorname{LF} 30 \operatorname{Day}(0.6)=-0.678+0.931 \cdot \log 10(\mathrm{DA})$ & 0.90 & 34 & 31 \\
\hline $\log 10 \operatorname{LF} 30 \operatorname{Day}(0.5)=-0.732+0.917 \cdot \log 10(\mathrm{DA})$ & 0.87 & 39 & 36 \\
\hline $\log 10 \operatorname{LF} 30 \mathrm{Day}(0.4)=-0.792+0.905 \cdot \log 10(\mathrm{DA})$ & 0.83 & 45 & 41 \\
\hline $\log 10 \operatorname{LF} 30 \operatorname{Day}(0.3)=-0.866+0.894 \cdot \log 10(\mathrm{DA})$ & 0.78 & 53 & 48 \\
\hline $\log 10 \operatorname{LF} 30 \operatorname{Day}(0.2)=-0.96+0.882 \cdot \log 10(\mathrm{DA})$ & 0.71 & 64 & 58 \\
\hline $\log 10 \operatorname{LF} 30 \operatorname{Day}(0.1)=-1.119+0.873 \cdot \log 10(\mathrm{DA})$ & 0.59 & 88 & 79 \\
\hline $\log 10 \operatorname{LF} 30$ Day $(0.05)=-1.263+0.866 \cdot \log 10(\mathrm{DA})$ & 0.48 & 117 & 104 \\
\hline $\log 10 \operatorname{LF} 30$ Day $(0.02)=-1.466+0.871 \cdot \log 10(\mathrm{DA})$ & 0.36 & 171 & 149 \\
\hline $\log 10 \operatorname{LF} 30$ Day $(0.01)=-1.597+0.869 \cdot \log 10(\mathrm{DA})$ & 0.28 & 230 & 195 \\
\hline $\log 10 \operatorname{LF} 30 \operatorname{Day}(0.005)=-1.714+0.863 \cdot \log 10(\mathrm{DA})$ & 0.22 & 317 & 260 \\
\hline $\log 10 \operatorname{LF} 30 \operatorname{Day}(0.002)=-1.884+0.866 \cdot \log 10(\mathrm{DA})$ & 0.16 & 491 & 384 \\
\hline $\log 10 \mathrm{LF} 30 \operatorname{Day}(0.001)=-2.235+0.963 \cdot \log 10(\mathrm{DA})$ & 0.14 & 851 & 621 \\
\hline
\end{tabular}


Table 10. Regional regression equations for estimating low flows of streams in Virginia.-Continued

\begin{tabular}{|c|c|c|c|}
\hline & Pseudo R-square $^{a}$ & $\begin{array}{c}\text { Average standard } \\
\text { error of } \\
\text { prediction }^{\mathrm{a}} \\
\text { (percent) }\end{array}$ & $\begin{array}{c}\text { Standard model } \\
\text { error }^{\mathrm{a}} \\
\text { (percent) }\end{array}$ \\
\hline $\log 10 \operatorname{LF} 1 \operatorname{Day}(0.9)=-1.276+1.213 \cdot \log 10(\mathrm{DA})$ & 0.91 & 71 & 69 \\
\hline $\log 10 \operatorname{LF} 1 \mathrm{Day}(0.8)=-1.508+1.253 \cdot \log 10(\mathrm{DA})$ & 0.89 & 84 & 81 \\
\hline $\log 10 \operatorname{LF} 1 \operatorname{Day}(0.7)=-1.689+1.284 \cdot \log 10(\mathrm{DA})$ & 0.88 & 96 & 93 \\
\hline $\log 10 \operatorname{LF} 1 \operatorname{Day}(0.5)=-2.033+1.346 \cdot \log 10(\mathrm{DA})$ & 0.85 & 126 & 121 \\
\hline $\log 10 \operatorname{LF} 1 \operatorname{Day}(0.4)=-2.241+1.387 \cdot \log 10(\mathrm{DA})$ & 0.82 & 150 & 145 \\
\hline $\log 10 \operatorname{LF} 4 \operatorname{Day}(0.9)=-1.226+1.209 \cdot \log 10(\mathrm{DA})$ & 0.94 & 70 & 68 \\
\hline $\log 10 \operatorname{LF} 4 \operatorname{Day}(0.8)=-1.461+1.254 \cdot \log 10(\mathrm{DA})$ & 0.93 & 81 & 79 \\
\hline $\log 10 \operatorname{LF} 7 \operatorname{Day}(0.9)=-1.091+1.176 \cdot \log 10(\mathrm{DA})$ & 0.94 & 67 & 65 \\
\hline $\log 10 \operatorname{LF} 7 D a y(0.8)=-1.36+1.234 \cdot \log 10(\mathrm{DA})$ & 0.93 & 76 & 74 \\
\hline $\log 10 \operatorname{LF} 30 \mathrm{Day}(0.8)=-0.991+1.155 \cdot \log 10(\mathrm{DA})$ & 0.95 & 60 & 58 \\
\hline $\log 10 \operatorname{LF} 30 \mathrm{Day}(0.7)=-1.166+1.187 \cdot \log 10(\mathrm{DA})$ & 0.94 & 66 & 64 \\
\hline
\end{tabular}

${ }^{a}$ Weighted-multiple-linear regression.

\section{Weighting Multiple Estimates}

Weighting techniques may improve flow estimates. Lowflow estimates may be improved by computing a weighted average of two independent estimates: (1) an estimate made by fitting a Log-Pearson Type III probability distribution to each vetted annual low-flow time series and adjusting it to account for zero flows, yielding an unconditional-probability curve, and (2) an estimate made by developing a regional regression equation describing streamgaging station low flows.

\section{Weighting of Independent Estimates}

A weighted estimate and variance at each low-flow station was calculated using information from low-flow frequency analysis and a corresponding regional regression equation. The equations developed in 1974 by Gilroy (Interagency Advisory Committee on Water Data, 1982, p. 8-1 of appendix 1 and p. 8-1 of appendix 8) were used to determine the weighted discharge and variance of low flows at each streamgaging station. The recommended procedure assumes that the two low-flow estimates are independent, which is true in most practical situations (Interagency Advisory Committee on Water Data, 1982; Cohn and others, 2001; Berenbrock, 2002).
The idea is that if two independent estimates are weighted in inverse proportion to their variances, then the variance of the weighted average is less than the variance of either estimate. This is accomplished using the following equations:

$$
Z=\frac{x\left(V_{y}\right)+y\left(V_{x}\right)}{V_{y}+V_{x}}
$$

and

$$
V_{z}=\frac{V_{x} V_{y}}{V_{x}+V_{y}},
$$

where

$$
\begin{array}{cc}
x=\text { a first independent estimate of low flow, } \\
y=\text { a second independent estimate of low flow, } \\
Z=\text { a weighted average estimate of low flow, } \\
V_{x}=\text { variance of a first independent estimate of } \\
\quad \text { low flow, } \\
V_{y}=\text { variance of a second independent estimate of } \\
\quad \text { low flow, and } \\
V_{z}=\begin{array}{c}
\text { variance of a weighted average estimate of } \\
\text { low flow. }
\end{array}
\end{array}
$$


Low-flow estimates determined using Log-Pearson Type III frequency analysis of long-term gages were used with low-flow estimates determined by regional regression equations from table 10 to yield the weighted low-flow estimates. These three low-flow estimates from (1) Log-Pearson Type III frequency analysis, (2) regional regression analysis, and (3) weighting the combined Log-Pearson Type III and regional regression estimates are listed in table 4 for long-term, continuous-record streamgaging stations.

\section{Low-Flow Characteristics}

Low-flow characteristics are found in tables 4,11 , and 12 (CD in pocket). Low-flow regression equations are found in tables 5, 6, and 10 .

Table 4 lists low-flow characteristics determined by lowflow frequency analysis of non-exceedance probabilities for long-term, continuous-record streamgaging stations. Table 4 also lists low-flow characteristics determined by regional regression equations, and weighted estimates of low-flow characteristics that combine the low-flow characteristics from low-flow frequency analysis, adjusted for zero flows, and regional regression equations. Table 10 lists preferred lowflow regional regression equations. These equations use basin drainage area as the chief explanatory variable. Candidate single- and multi-parameter regional regression equations, not listed in this report, were developed for each P-percent chance low flow for each of six regions. Equations with significant explanatory power, easily measured explanatory variables, ease of interpretation and use, and lower risks of explanatory variable inflation or collinearity were selected as final regional regression models. Table 5 lists equations for low-flow frequency characteristics at selected short-term, continuousrecord streamgaging stations computed using the MOVE. 1 method. Table 6 lists equations for low-flow frequency characteristics at selected partial-record, streamgaging stations computed using the MOVE. 1 method. Table 11 lists low-flow characteristics for selected short-term, continuous record, streamgaging stations, transferred from continuous-record index stations using the MOVE. 1 method. Table 12 lists low-flow characteristics for partial-record, streamgaging stations, transferred from continuous-record index stations using the MOVE. 1 method. Table 3 lists daily flow-duration statistics and flow variability indices for selected streamgaging stations. Table 2 lists monthly streamflow statistics for selected continuous-record streamgaging stations.

Basin characteristics used in developing regional regression equations are summarized in tables 7 through 9 . Table 7 lists statistics summarizing basin characteristics that were selected for regional regression of low flows in Virginia. Table 8 lists the names of selected basin characteristics along with their definitions and data sources. Table 9 displays basin characteristics chosen for testing in exploratory regional regression analyses.

\section{Other Methods for Estimation at Ungaged Sites}

The appropriate method for calculating low-flow estimates at an ungaged site depends on whether (1) the drainage basin lies within a single low-flow region, (2) the drainage basin crosses low-flow region boundaries, or (3) the ungaged site is located on a gaged stream.

Low-flow estimates at sites on ungaged streams that lie entirely within a single low-flow region may be calculated using the equations listed in table 10 for the appropriate region.

Low-flow estimates at sites with drainage basins that cross low-flow regional boundaries may be made by first determining the percentage of the basin in each region. Lowflow estimates are then computed for the entire basin area by using the appropriate equation for each low-flow region, then multiplying the low flow for each part of the basin by the percentage of the entire basin in that region, and summing the contributions from each low-flow region.

Low-flow estimates at an ungaged site located on a gaged stream may be adjusted using a flow-routing equation developed by Hayes, consisting of the minimum consecutive-day (d-day) discharge of interest, multiplied by a simple drainagearea ratio raised to the 1.2 power. The equation takes the form:

$d Q T_{j}=d Q T_{i}\left[\frac{A_{j}}{A_{i}}\right]^{1.2}$ for values of $\left[\frac{A_{j}}{A_{i}}\right] \geq 0.25$ and $\leq 4.0$,

where

$$
\begin{aligned}
d Q T_{j}= & \text { the average minimum d-consecutive day } \\
& \text { discharge having a T-year recurrence } \\
& \text { interval, in cubic feet per second; } \\
j= & \text { the location at an ungaged site or confluence } \\
& \text { where the low-flow value is to be } \\
& \text { determined; } \\
i= & \text { the location at a gaged site where low-flow } \\
& \text { values have previously been determined; } \\
& \text { and }
\end{aligned}
$$

Any computed low-flow value that is calculated as negative is assumed to be zero. The equation is limited to drainage area ratios of no less than 0.25 and no more than 4.0 (Hayes, 1991).

\section{Example Applications}

The following four exercises provide step-by-step examples of how to perform calculations and apply the methods suggested in this report to estimate low flows. Example calculations are shown for estimating low flow by (1) using 
the regression equations provided in this report, (2) using the drainage-area ratio method when a drainage basin spans two or more physiographic regions, (3) using a nearby gage for an ungaged site, and (4) using a gaged site.

\section{Use of Regression Equations}

Example 1. Estimating the 30-day averaged 1.1-year (0.9 P-percent chance) low flow at an ungaged site with a drainage basin completely contained within the Blue Ridge region.

Given: Drainage area (DA) of $7.3 \mathrm{mi}^{2}$ for this basin, measured from a 1:24,000-scale topographic map.

Solution: The regression estimate for the site is computed using the appropriate Blue Ridge regional equation in table 10 for the 30 -day averaged 1.1 -year ( 0.9 percent chance) low flow as follows:

$$
\begin{aligned}
\log 10\left(30 \mathrm{Q}_{(1.1)}\right) & =-0.489+1.096 \bullet \log 10(\mathrm{DA})(\text { from table } 10) \\
& =-0.489+1.096 \bullet \log 10(7.3) \\
& =-0.489+1.096 \bullet 0.86 \\
& =0.46 \\
30 \mathrm{Q}_{(1.1)} & =10^{0.46}=2.87 \mathrm{ft}^{3} / \mathrm{s}
\end{aligned}
$$

For the Coastal Plain region:

$\log 10\left(7 \mathrm{Q}_{(2)}\right)=-1.106+0.868 \bullet \log 10(\mathrm{DA})($ from table 10$)$

$$
\begin{aligned}
& =-1.106+0.868 \bullet \log 10(53) \\
& =-1.106+0.868 \bullet 1.72 \\
& =0.39 \\
7 Q_{(2)} & =10^{0.39}=2.46 \mathrm{ft}^{3} / \mathrm{s}
\end{aligned}
$$

For the Piedmont Region:

$$
\begin{aligned}
\log 10\left(7 \mathrm{Q}_{(2)}\right) & =-0.683+0.898 \bullet \log 10(\mathrm{DA})(\text { from table } 10) \\
& =-0.683+0.898 \bullet \log 10(53) \\
& =-0.683+0.898 \bullet 1.72 \\
& =0.86 \\
7 \mathrm{Q}_{(2)} & =10^{0.86}=7.27 \mathrm{ft}^{3} / \mathrm{s}
\end{aligned}
$$

The combined estimate for the basin $\mathrm{Q}_{(702)}$ :

$$
\begin{aligned}
& \left(\mathrm{Q}_{(7 \mathrm{Q} 2) \mathrm{r} 1} \bullet \text { fraction }_{\mathrm{r} 1}\right)+\left(\mathrm{Q}_{(7 \mathrm{Q} 2) \mathrm{r} 2} \bullet \text { fraction }_{\mathrm{r} 2}\right)=(2.46 \bullet 0.27) \\
& +(7.27 \bullet 0.73)=5.97 \mathrm{ft}^{3} / \mathrm{s}
\end{aligned}
$$

\section{Ungaged Site with Nearby Gage}

Example 3. Estimating the 4-day averaged 50-year (0.02 P-percent chance) low flow at an ungaged site on the New River, located upstream from the New River gage below Route 11 at Radford, Virginia, streamgaging station number 03171000 .

(0.5 P-percent chance) low flow at an ungaged site with a drainage basin that spans the Coastal Plain and Piedmont regions.

\section{Given:}

1. Drainage area (DA) of $53 \mathrm{mi}^{2}$ for the entire basin, measured from a 1:24,000-scale topographic map.

2. Twenty-seven percent of the basin is located in the Coastal Plain.

3. Seventy-three percent of the basin is located in the Piedmont.

Solution: Calculate the 2-year (0.5 P-percent chance) low-flow discharge for the basin using the two regional equations, then use the fraction of the total drainage area in each region as a weighting factor to compute a final estimate, as follows:

\section{Given:}

1. Drainage area $\left(A_{j}\right)$ of $1,141 \mathrm{mi}^{2}$ for the basin above the ungaged site, measured from a 1:24,000-scale topographic map.

2. Drainage area $\left(\mathrm{A}_{i}\right)$ of $2,767 \mathrm{mi}^{2}$ for the basin above the gaged site, measured from a 1:24,000scale topographic map. streamgaging station number 03171000 from table 4 , the 4Q50 low flow at the ungaged site $=$ $751\left[\frac{1,141}{2,767}\right]^{1.2}=259 \mathrm{ft}^{3} / \mathrm{s}$.
Solution: Using eq 8 and the measured discharge at 


\section{Gaged Site}

Example 4. Estimating the 7-day averaged 100-year low flow at a gaged site on the North Fork of the Rivanna River at Route 606, near Earlysville, Virginia.

Given: Because this is a gaged site, the 7-day averaged 100 -year low flow may be read directly from table 4 (Low-flow characteristics of streamgaging stations in Virginia, p. 27).

Solution: In table 4, find streamgaging station number 02032640 in the left hand column of the 7-day averaged low-flow discharge section of the table, identifying the gage on the North Fork of the Rivanna River at Route 606, near Earlysville, Virginia. Read across to find the low-flow discharge of $0.14 \mathrm{ft}^{3} / \mathrm{s}$ corresponding to the P-percent chance low-flow probability of 0.01 (100-yr recurrence interval): $7 \mathrm{Q}_{(100)}=0.14 \mathrm{ft}^{3} / \mathrm{s}$.

\section{Summary}

This report provides P-percent chance estimates of 1-, 4-, 7-, and 30-day averaged non-exceedance probabilities adjusted for instances of zero flow, and regional regression equations organized by physiographic region that may be used to estimate annual non-exceedance probability low flows using basin characteristics. Regression equations developed using the Maintenance of Variance with Extension (MOVE.1) method describe the line of organic correlation (LOC) with an appropriate index-site for low flows at 136 short-term, continuous-record streamgaging stations and 613 partialrecord, streamgaging stations. Monthly streamflow statistics computed on the individual daily mean streamflows of selected continuous-record streamgaging stations and statistics describing flow-duration are also presented. Regional regression equations estimate P-percent chance low flows using basin characteristics. Methods are explained. Text, figures, and lists are provided summarizing low-flow sites selected for study, delineated physiographic regions, statistics associated with low-flow basin characteristics, regional regression equations, weighted low-flow estimates, streamgaging station low-flow values, basin characteristic definitions, and basin characteristic datasources.

Regional regression analyses of low-flow response associated with explanatory basin characteristics provide insights into the nature of low flows across Virginia. Regional regression equations describing low flow as a function of basin drainage area and other explanatory basin characteristics are identified across the range of 1-, 4-, 7-, and 30-day average P-percent chance low flows within each region identified for study.
Candidate regional regression equations describing each 1-, 4-, 7-, and 30-day average P-percent chance low flow as a function of basin drainage area in the Coastal Plain yielded median R-square of $0.58,0.59,0.65$, and 0.65 and median root mean square error of $0.61,0.63,0.55$, and 0.53 , respectively.

Candidate regional regression equations describing each 1-, 4-, 7-, and 30-day average P-percent chance low flow as a function of basin drainage area in the Piedmont, excluding the Mesozoic Basins located within the Piedmont physiographic region, yielded median R-square of $0.65,0.66,0.68$, and 0.70 , and median root mean square error of $0.67,0.66,0.65$, and 0.61 , respectively.

Candidate regional regression equations describing each 1-, 4-, 7-, and 30-day average P-percent chance low flow as a function of basin drainage area in the Mesozoic Basins yielded median R-square of $0.80,0.81,0.82$, and 0.86 , and median root mean square error of $0.48,0.48,0.47$, and 0.40 , respectively.

Candidate regional regression equations describing each 1-, 4-, 7-, and 30-day average P-percent chance low flow as a function of basin drainage area in the Blue Ridge yielded median R-square of $0.74,0.79,0.79$, and 0.83 , and median root mean square error of $0.53,0.47,0.48$, and 0.41 , respectively.

Candidate regional regression equations describing each 1-, 4-, 7-, and 30-day average P-percent chance low flow as a function of basin drainage area in the Valley and Ridge yielded median R-square of $0.76,0.78,0.77$, and 0.80 , and median root mean square error of $0.40,0.39,0.39$, and 0.36 , respectively.

Candidate regional regression equations describing each 1-, 4-, 7-, and 30-day average P-percent chance low flow as a function of basin drainage area in the Appalachian Plateaus yielded median R-square of $0.49,0.59,0.57$, and 0.68 , and median root mean square error of $0.45,0.32,0.33$, and 0.25 , respectively.

Estimates of magnitude, frequency, and duration of low flows provide insights into the dynamics and variability of water moving through Virginia's unique stream systems. This information can be used in management decisionmaking while providing a basis for analysis of future streamflow response to changes in ecosystem and climate.

\section{Acknowledgments}

The authors extend their thanks to the Virginia Department of Environmental Quality, whose continued collaboration and assistance made this report possible. We also extend special thanks to the following individuals for their exceptional and energetic guidance, work, advice, review, and editing as information was compiled and this report was prepared: Donald C. Hayes, George E. Harlow, Jr., Theodore B. Samsel, and Robert B. Banks of the U.S. Geological Survey. 


\section{References}

Aitchison, J., and Brown, J.A.C., 1957, The lognormal distribution, with special reference to its uses in economics: Cambridge, U.K., Cambridge University Press, 176 p.

Belsley, D.A., Kuh, E., and Welsch, R.E., 1980, Regression diagnostics: New York, John Wiley and Sons, 292 p.

Benson, M.A., 1962, Factors influencing the occurrence of floods in a humid region of diverse terrain: U.S. Geological Survey Water-Supply Paper 1580-B, 64 p.

Benson, M.A., 1964, Factors affecting the occurrence of floods in the southwest: U.S. Geological Survey Water-Supply Paper 1580-D, 72 p.

Berenbrock, C., 2002, Estimating the magnitude of peak flows at selected recurrence intervals for streams in Idaho: U.S. Geological Survey Water-Resources Investigations Report 02-4170, 59 p.

Bisese, J.A., 1995, Methods for estimating magnitude and frequency of peak discharges of rural, unregulated streams in Virginia: U.S. Geological Survey Water-Resources Investigations Report 94-4148, 70 p.

Burnham, K.P., and Anderson, D.R., 2002, Model selection and inference-A practical information-theoretic approach: New York, Springer-Verlag, 488 p.

Cohn, T.A., Lane, W.L., and Stedinger, J.R., 2001, Confidence intervals for expected moments algorithm flood quantile estimates: Water Resources Research, v. 37, no. 6, p. 16951706.

Cook, R.D., and Weisberg, S., 1982, Residuals and influence in regression: New York, Chapman and Hall, 229 p.

Cushing, E.M., Kantrowitz, I.H., and Taylor, K.R., 1973, Water resources of the Delmarva Peninsula: U.S. Geological Survey Professional Paper 822, 58 p.

Dicken, C.L., Nicholson, S.W., Horton, J.D., Kinney, S.A., Gunther, G., Foose, M.P., and Mueller, J.A.L., 2005, Preliminary integrated geologic map databases for the United States-Delaware, Maryland, New York, Pennsylvania, and Virginia: U.S. Geological Survey Open-File Report 2005-1325, 48 p. (Also available at http://pubs.usgs.gov/ of $/ 2005 / 1325 /$.)

Dillow, J.A., 1996, Technique for estimating magnitude and frequency of peak flows in Maryland: U.S. Geological Survey Water-Resources Investigations Report 95-4154, 55 p.
Edwards, L.E., Barron, J.A., Bukry, David, Bybell, L.M., Cronin, T.M., Poag, C.W., Weems, R.E., and Wingard, G.L., 2005, Paleontology of the upper Eocene to Quaternary postimpact section in the USGS-NASA Langley core, Hampton, Virginia, chap. H of Horton, J.W., Jr., Powars, D.S., and Gohn, G.S., eds., Studies of the Chesapeake Bay impact structure - The USGS-NASA Langley corehole, Hampton, Virginia, and related coreholes and geophysical surveys: U.S. Geological Survey Professional Paper 1688, p. H1-H47, 9 fossil plates, 2 oversize figures.

Eng, Ken, Chen, Y.-Y., and Kiang, J.E., 2009, User's guide to the weighted-multiple-linear regression program (WREG version 1.0): U.S. Geological Survey Techniques and Methods, book 4, chap. A8, 21 p., accessed March 3, 2011, at http://pubs.usgs.gov/tm/tm4a8/.

Fenneman, N.M., 1938, Physiography of Eastern United States: New York, McGraw-Hill, 714 p.

Fenneman, N.M., and Johnson, D.W., 1946, Physiographic divisions of the conterminous U.S.: U.S.Geological Survey map product, scale 1:7,000,000. (Also available at http:// water.usgs.gov/GIS/metadata/usgswrd/XML/physio.xml.)

Fichter, L.S., and Baedke, S.J., 1999, A description of the geology of Virginia, accessed June 22, 2010, at http:// csmres.jmu.edu/geollab/vageol/vahist/PhysProv.html.

Glatfelter, D.R., 1984, Techniques for estimating magnitude and frequency of floods in Indiana: U.S. Geological Survey Water-Resources Investigations Report 84-4134, 110 p.

Hannum, C.H., 1976, Techniques for estimating magnitude and frequency of floods in Kentucky: U.S. Geological Survey Water-Resources Investigations Report 76-62, 70 p.

Hayes, D.C., 1991, Low-flow characteristics of streams in Virginia: U.S. Geological Survey Water-Supply Paper 2374, $69 \mathrm{p}$.

Hayes, D.C., and Nelms, D.L., 2001, Base-flow characteristics of streams in the Valley and Ridge, Blue Ridge, and Piedmont physiographic provinces of Virginia and other mid-Atlantic States [abs.], in Adams, D.B., Burke, Katrina, Hemingway, Bruce, Key, Jeff, and Yurewicz, Michael, comps., U.S. Geological Survey Appalachian Region Integrated Science Workshop proceedings, Gatlinburg, Tennessee, October 22-26, 2001: U.S. Geological Survey OpenFile Report 01-406, p. 87-88.

Hayes, D.C., and Wiegand, U., 2006, Drainage areas of selected streams in Virginia: U.S. Geological Survey OpenFile Report 2006-1308, 51 p. 
Hayes, D.C., and Young, R.L., 2005, Comparison of peak discharge and runoff characteristic estimates from the rational method to field observations for small basins in central Virginia: U.S. Geological Survey Scientific Investigations Report 2005-5254, 44 p.

Helsel, D.R., and Hirsch, R.M., 2002, Statistical methods in water resources: U.S. Geological Survey Techniques of Water-Resources Investigations Report, book 4, chap. A3, $510 \mathrm{p}$.

Hirsch, R.M., Slack, J.R., and Smith, R.A., 1982, Techniques of trend analysis for monthly water quality data: Water Resources Research, v. 18, no. 1, p. 107-121.

Homer, C., Huang, C., Yang, L., Wylie, B., and Coan, M., 2004, Development of a 2001 National Land-Cover Database for the United States: Photogrammetric Engineering and Remote Sensing, v. 70, no. 7, p. 829-840.

Interagency Advisory Committee on Water Data, 1982, Guidelines for determining flood flow frequency: Water Resources Council Bulletin 17B, 28 p.

Jennings, M.E., and Benson, M.A., 1969, Frequency curves for annual flood series with some zero events or incomplete data: Water Resources Research, v. 5, no. 1, p. 276-280.

Kirby, W., 1980, Computer routines for probability distributions, random numbers, and related functions: U.S. Geological Survey Open-File Report 80-448, 61 p.

Lane, E.W., and Lei, K., 1950, Stream flow variability: Transactions of the American Society of Civil Engineers, v. 115, p. $1084-1134$.

Langbein, W.B., and Iseri, K.T., 1995, General introduction and hydrologic definitions, manual of hydrology-Part 1. General surface-water techniques: U.S. Geological Survey Water-Supply Paper 1541-A, 29 p. (Also available at http:// water.usgs.gov/wsc/glossary.html.)

Lumb, A.M., Kittle, J.L., Jr., and Flynn, K.M., 1990, Users manual for ANNIE, computer program for interactive hydrologic analysis and data management: U.S. Geological Survey Water-Resources Investigations Report 89-4080, $236 \mathrm{p}$.

Lynch, D.D., 1987, Hydrologic conditions and trends in Shenandoah National Park, Virginia: U.S. Geological Survey Water-Resources Investigations Report 87-4131, 115 p.

Lynch, D.D., Nuckels, E.H., and Zenone, C., 1987, Low-flow characteristics and chemical quality of streams in the Culpeper geologic basin, Virginia and Maryland: U.S. Geological Survey Miscellaneous Investigations Map I-1313-H, scale $1: 125,000$.

Miller, E.M., 1969, Floods in Virginia, magnitude and frequency: U.S. Geological Survey Open-File Report, 54 p.
Miller, E.M., 1978, Technique for estimating magnitude and frequency of floods in Virginia: U.S. Geological Survey Water-Resources Investigations Report 78-5, 83 p.

Mixon, R.B., Berquist, C.R., Jr., Newell, W.L., Johnson, G.H., Powars, D.S., Schindler, J.S., and Rader, E.K., 1989, Geologic map and generalized cross sections of the Coastal Plain and adjacent parts of the Piedmont, Virginia with generalized geologic cross sections: U.S. Geological Survey Miscellaneous Investigations Map I-2033, scale 1:250,000.

Mohler, E.H., Jr., and Hagan, G.F., 1981, Low flow of streams in Fairfax County, Virginia: U.S. Geological Survey OpenFile Report 81-63, 30 p.

Mosteller, F., and Tukey, J.W., 1977, Data analysis and regression-A second course in statistics: Reading, Massachusetts, Addison-Wesley, 588 p.

National Oceanic and Atmospheric Administration, 2007, National Weather Service Hydrometeorological Design Studies Center, precipitation frequency data server, accessed January 27, 2009, at http://dipper.nws.noaa.gov/hdsc/pfds/.

Nelms, D.L., Harlow, G.E., Jr., and Hayes, D.C., 1997, Baseflow characteristics of streams in the Valley and Ridge, the Blue Ridge, and the Piedmont Physiographic Provinces of Virginia: U.S. Geological Survey Water-Supply Paper 2457, $48 \mathrm{p} ., 1 \mathrm{pl}$.

Nuckels, E.H., 1970, Virginia streamflow data program analysis: U.S. Geological Survey Open-File Report, 54 p.

Paybins, K.S., 2008, Basin characteristics for selected streamflow-gaging stations in and near West Virginia: U.S. Geological Survey Open-File Report 2008-1087, 9 p. (Also available at $h t t p: / / p u b s . u s g s . g o v / o f / 2008 / 1087 /$.

PRISM Climate Group, Oregon State University, 2007, Mean annual precipitation from 1971 to 2000 and average monthly rainfall for January, February, and March, accessed May 5, 2008, at http://prism.oregonstate.edu/products/ matrix.phtml.

Prugh, B.J., Jr., Nuckels, E.H., and Humphreys, C.G., 1991, Annual maximum stages and discharges of selected streams in Virginia through 1990: U.S. Geological Survey Open-File Report 90-587, $442 \mathrm{p}$.

Ries, K.G., III, and Friesz, P.J., 2000, Methods for estimating low-flow statistics for Massachusetts streams: U.S. Geological Survey Water-Resources Investigations Report 00-4135, $81 \mathrm{p}$.

Sall, J., 1990, Leverage plots for general linear hypotheses: The American Statistician, v. 44, no. 4, p. 308-315.

Smith, R.W., 1981, Rock type and minimum 7-day/10-year flow in Virginia streams: Virginia Water Resources Research Center Bulletin 116, 43 p. 
Speer, P.R., and Gamble, C.R., 1964a, Magnitude and frequency of floods in the United States-Part 2A, South Atlantic slope basins, James River to Savannah River: U.S. Geological Survey Water-Supply Paper 1673, 329 p.

Speer, P.R., and Gamble, C.R., 1964b, Magnitude and frequency of floods in the United States-Part 3B, Cumberland and Tennessee River basins: U.S. Geological Survey Water-Supply Paper 1676, 340 p.

Speer, P.R., and Gamble, C.R., 1965, Magnitude and frequency of floods in the United States-Part 3A, Ohio River basin except Cumberland and Tennessee River basins: U.S. Geological Survey Water-Supply Paper 1675, 630 p.

Stedinger, J.R., and Tasker, G.D., 1985, Regional hydrologic analysis 1 -ordinary, weighted, and generalized least squares compared: Water Resources Research, v. 21, no. 9, p. 1421-1432.

Stedinger, J.R., and Thomas, W.O., Jr., 1985, Low-flow frequency estimation using base-flow measurements: U.S. Geological Survey Open-File Report 85-95, 22 p.

Tasker, G.D., 1975, Combining estimates of low-flow characteristics of streams in Massachusetts and Rhode Island: Journal of Research of the U.S. Geological Survey, v. 3, no. 1, p. 107-112.

Tasker, G.D., 1987, A comparison of methods for estimating low flow characteristics of streams, Water Resources Bulletin, v. 23, no. 6, p. 1077-1083.

Tasker, G.D., and Stedinger, J.R., 1989, An operational GLS model for hydrologic regression: Journal of Hydrology, v. 111, p. 361-375.
The College of William \& Mary Department of Geology, 2010, The geology of Virginia, accessed June 22, 2010, at http://web.wm.edu/geology/virginia/.

Tice, R.H., 1954, Magnitude and frequency of floods in the Shenandoah Valley of Virginia: U.S. Geological Survey Open-File Report, 33 p.

Trainer, F.W., and Watkins, F.A., Jr., 1975, Geohydrologic reconnaissance of the upper Potomac River basin: U.S. Geological Survey Water-Supply Paper 2035, 68 p.

U.S. Department of Agriculture, 2007, U.S. General Soil Map (STATSGO2) for Virginia, prepared by the soil survey staff of the Natural Resources Conservation Service, accessed during 2007 at http://soildatamart.nrcs.usda.gov.

U.S. Geological Survey, 2006, National hydrologic dataset, accessed during 2007 at http://nhdgeo.usgs.gov/viewer.htm.

U.S. Geological Survey, 2007, National elevation dataset, accessed during 2007 at http://seamless.usgs.gov.

Wetzel, K.L., and Bettandorff, J.M., 1986, Techniques for estimating streamflow characteristics in the eastern and interior coal provinces of the United States: U.S. Geological Survey Water-Supply Paper 2276, 80 p.

Yang, L., Huang, C., Homer, C.G., Wylie, B.K., and Coan, M.J., 2002, An approach for mapping large-area impervious surfaces - Synergistic use of Landsat 7 ETM+ and high spatial resolution imagery: Canadian Journal of Remote Sensing, v. 29, no. 2, p. 230-240. 


\section{Glossary}

[Unless otherwise noted, definitions are based on Langbein, W.B., and Iseri, K.T, 1995, Hydrologic definitions, available at USGS Web site http://water.usgs.gov/wsc/glossary.html]

Cubic feet per second ( $\left.\mathbf{f t}^{3} / \mathbf{s}\right)$ A measure of the rate of water discharge representing a volume of 1 cubic foot of water passing a given point in 1 second.

Discharge The volume of water that passes a given point within a given period of time.

Drainage area The area measured in a horizontal plane and enclosed by a topographic divide from which direct surface runoff from precipitation normally drains by gravity into a stream, upstream from a specified location.

Gage A water-level measuring device at a streamflow-gaging station.

Gage height The water-surface elevation referred to an arbitrary gage datum. Gage height is often used interchangeably with the more general term stage although gage height is more appropriate when used with a reading on a gage.

Hydrologic unit A geographic area representing part or all of a surface-water drainage basin or distinct hydrologic feature as delineated on a State Hydrologic Unit Map prepared by the U.S. Geological Survey.

Location A description of the placement of a streamflow-gaging station. Location may include the latitude, longitude, datum, county, and hydrologic unit code of the station.

Low-flow frequency curve A graph showing the magnitude and frequency of minimum flows for a period of given length. Frequency is usually expressed as the average interval, in years, between recurrences of an annual minimum flow equal to or less than that shown by the magnitude scale.

Regulation The artificial manipulation of the flow of a stream.

Stage-discharge relation The relation between gage height and the rate at which water flows in a stream. It is defined by measurements of stage and discharge, by theoretical assumptions based on hydraulic properties of the stream channel or manmade flow-confining structures, or by a combination of both.

Streamgaging or streamflow-gaging station A particular site on a stream, canal, lake, or reservoir where systematic observations of water heights and water discharges are made.

Water year The 12-month period from October 1 through September 30. The date of the water year is designated by the calendar year in which the period ends and which includes 9 of the 12 months. A water year beginning October 1, 2005, and ending September 30, 2006, is called the "2006 water year." 


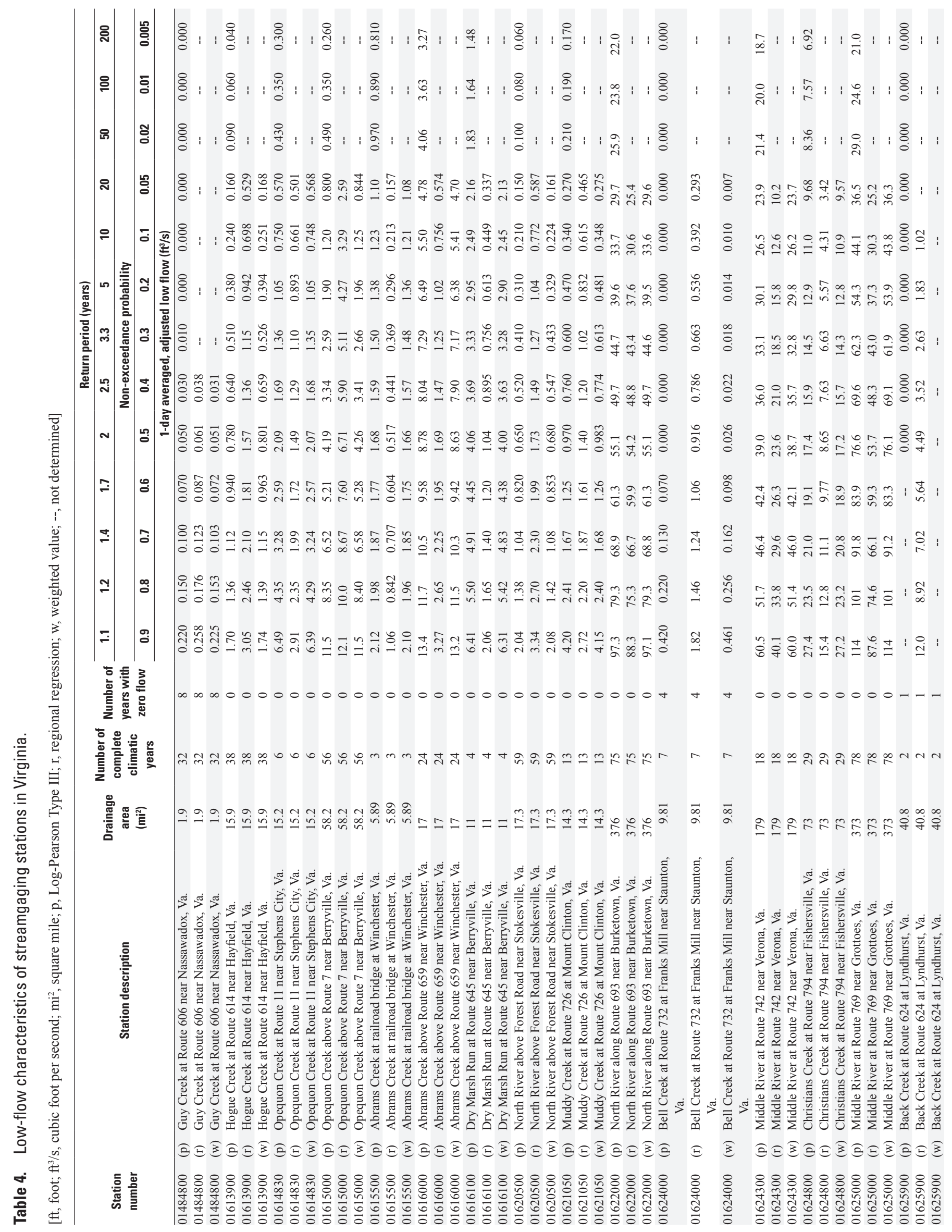




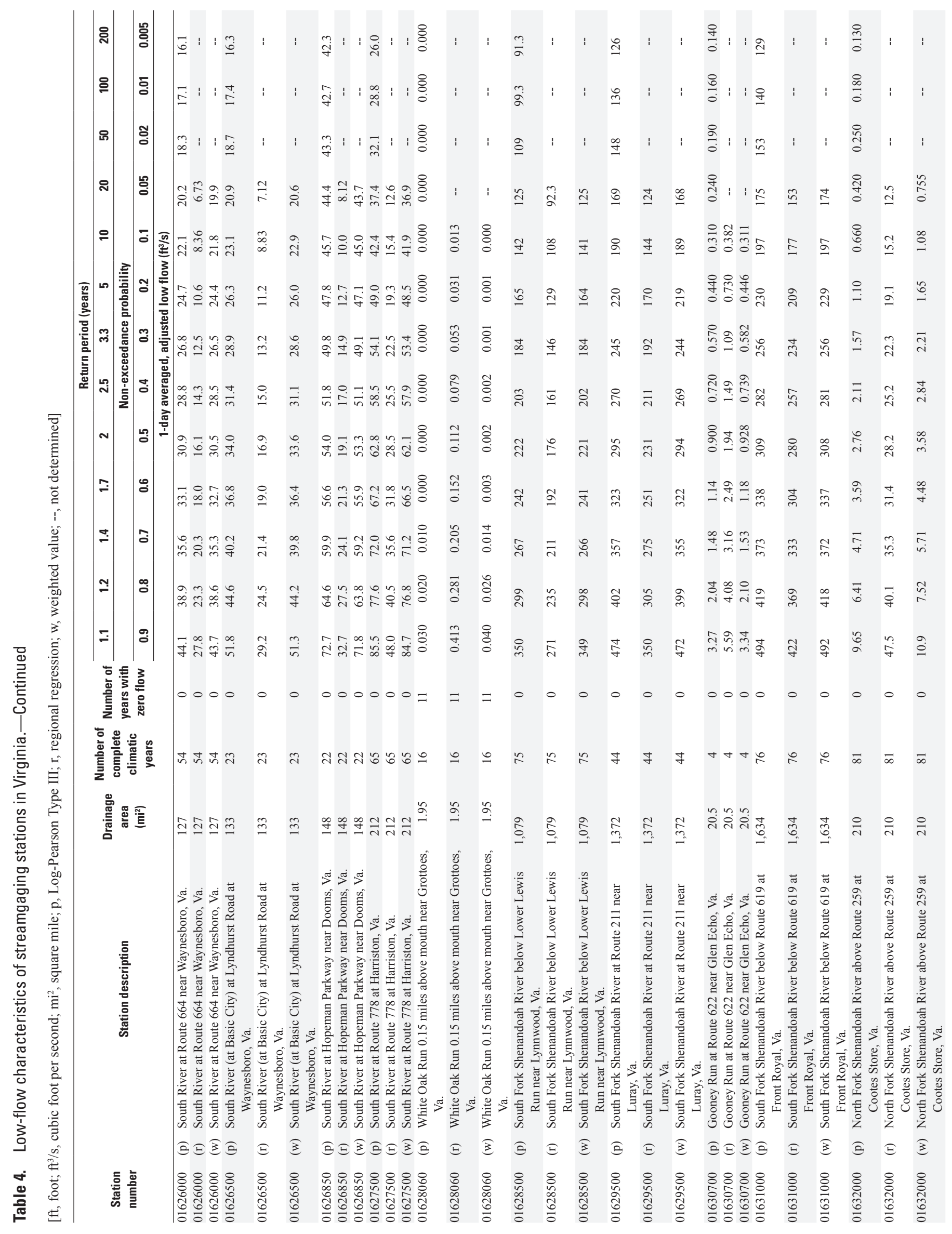




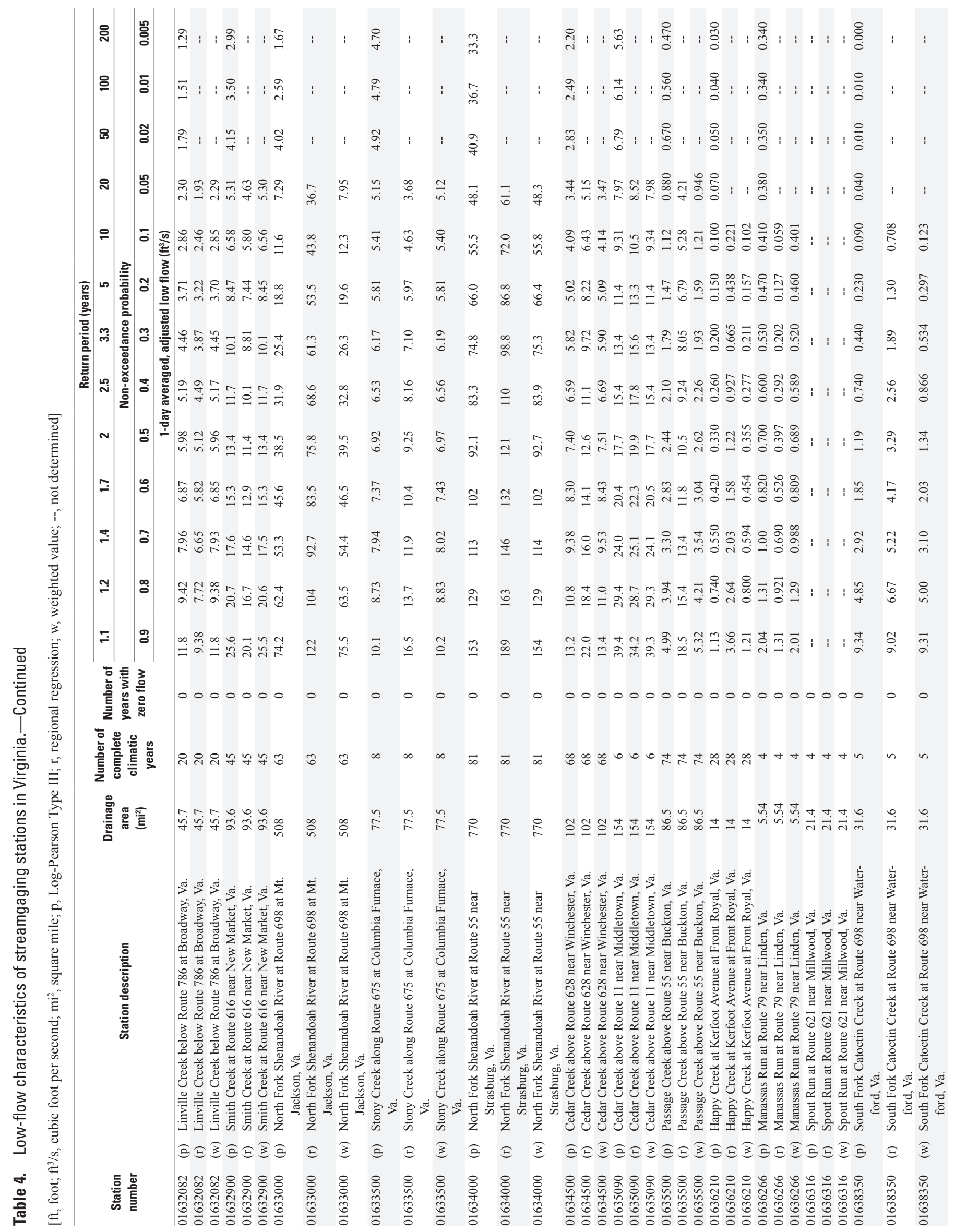




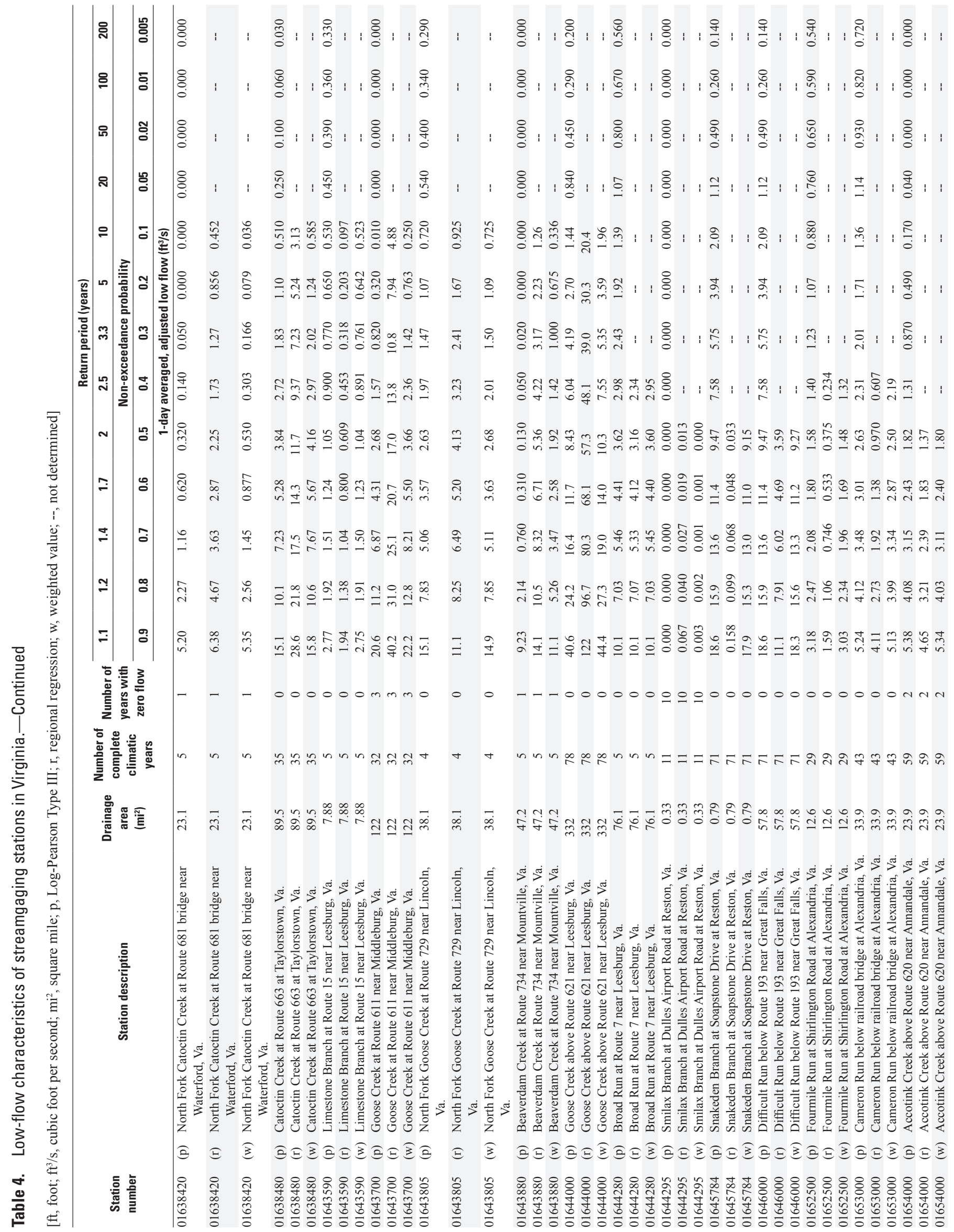




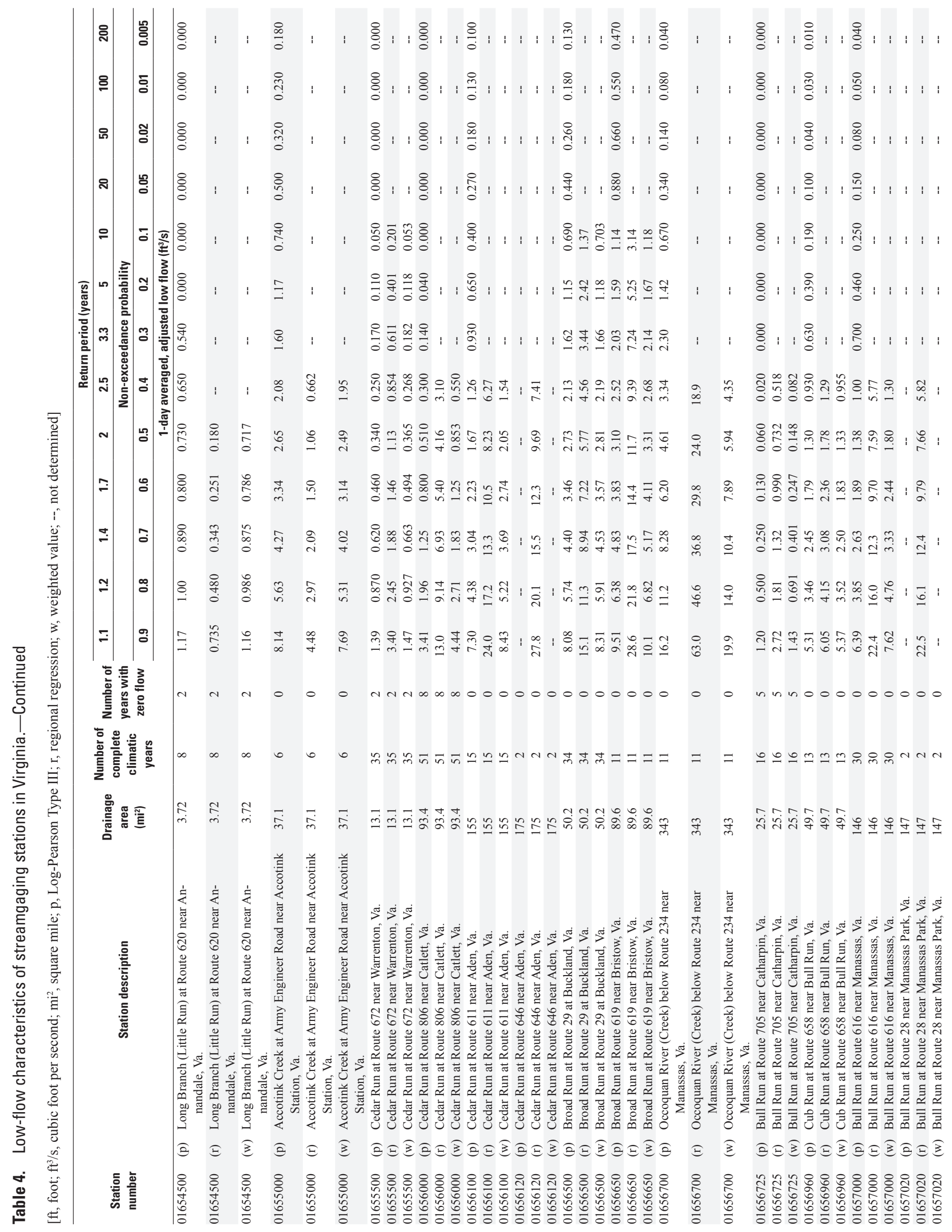




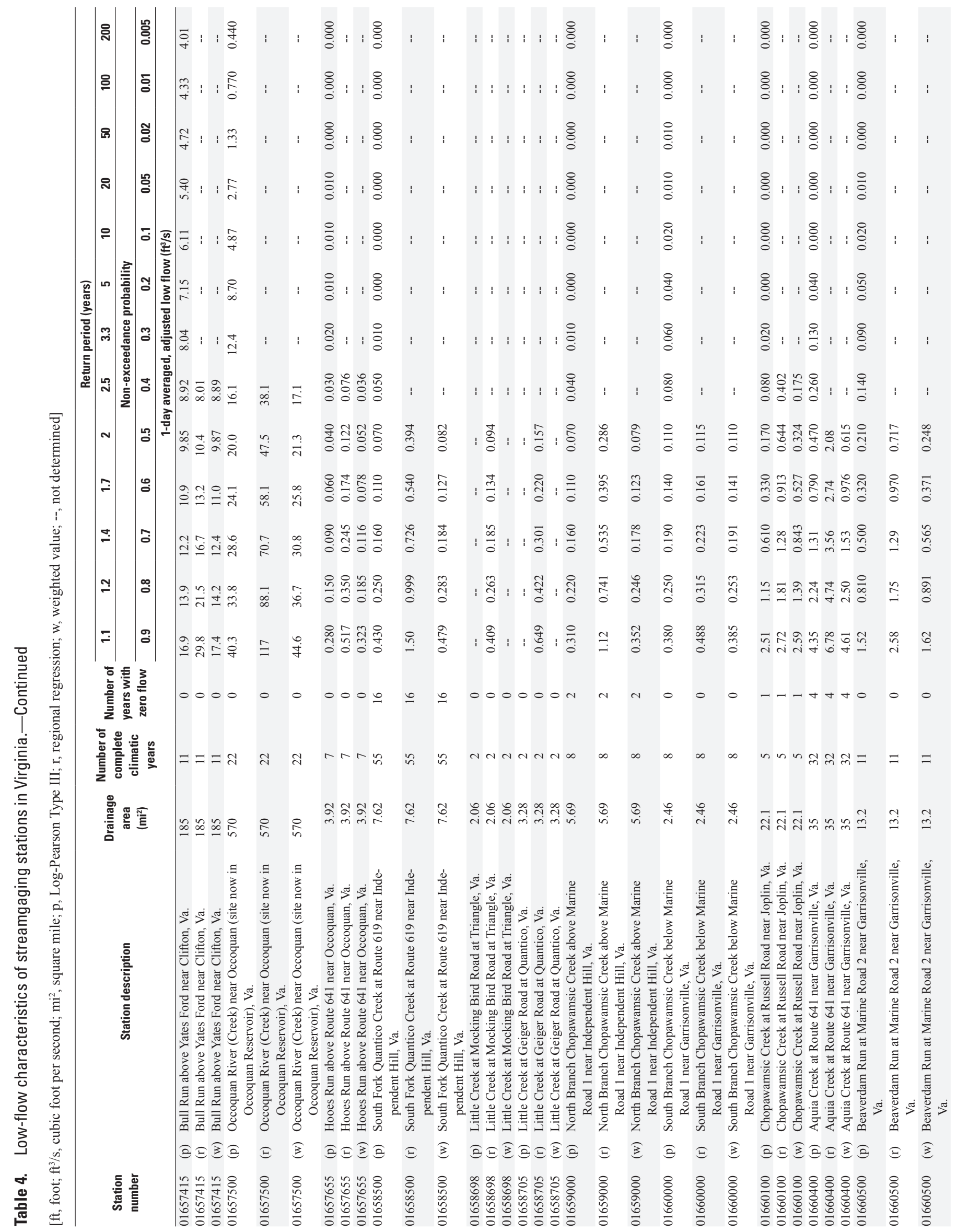




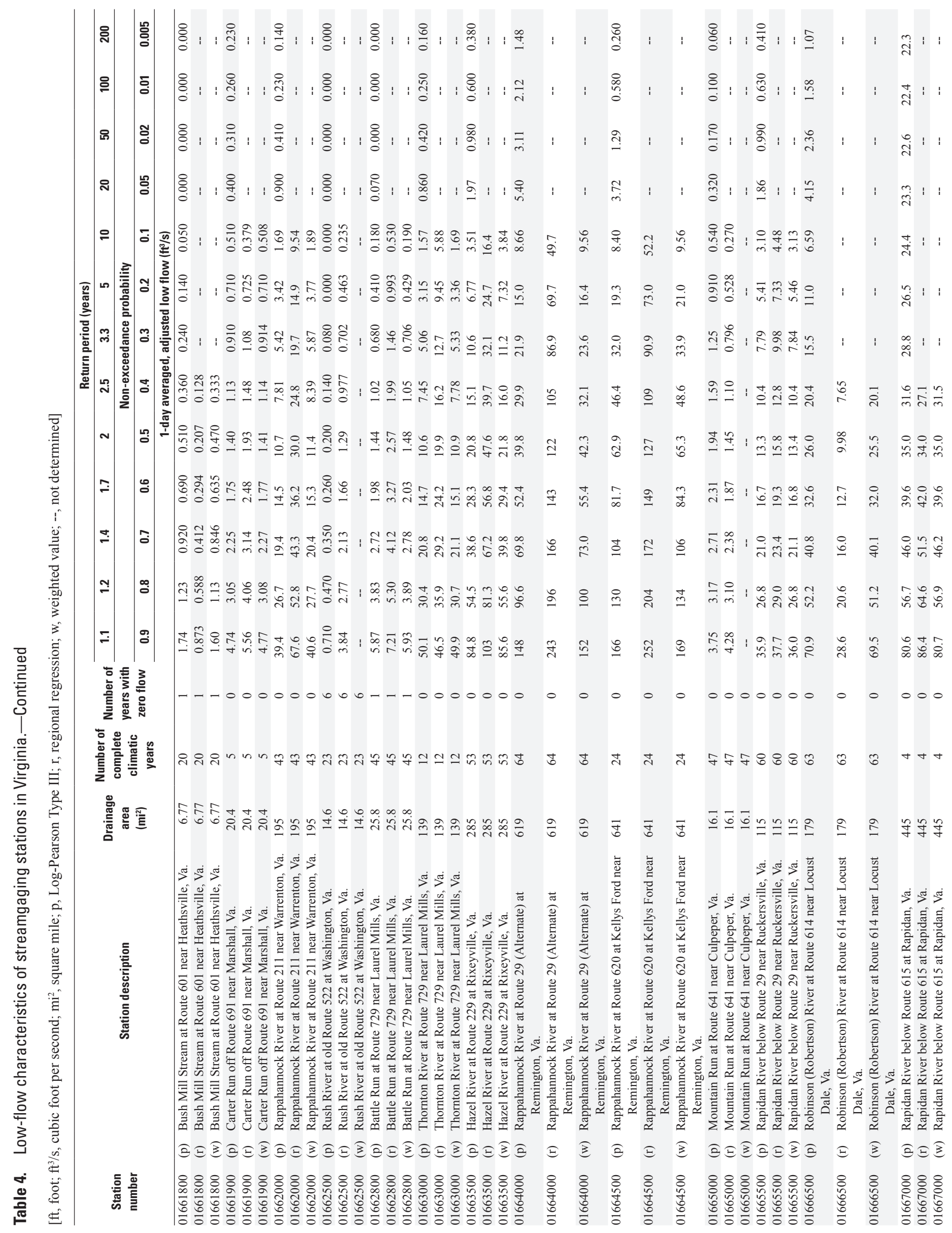




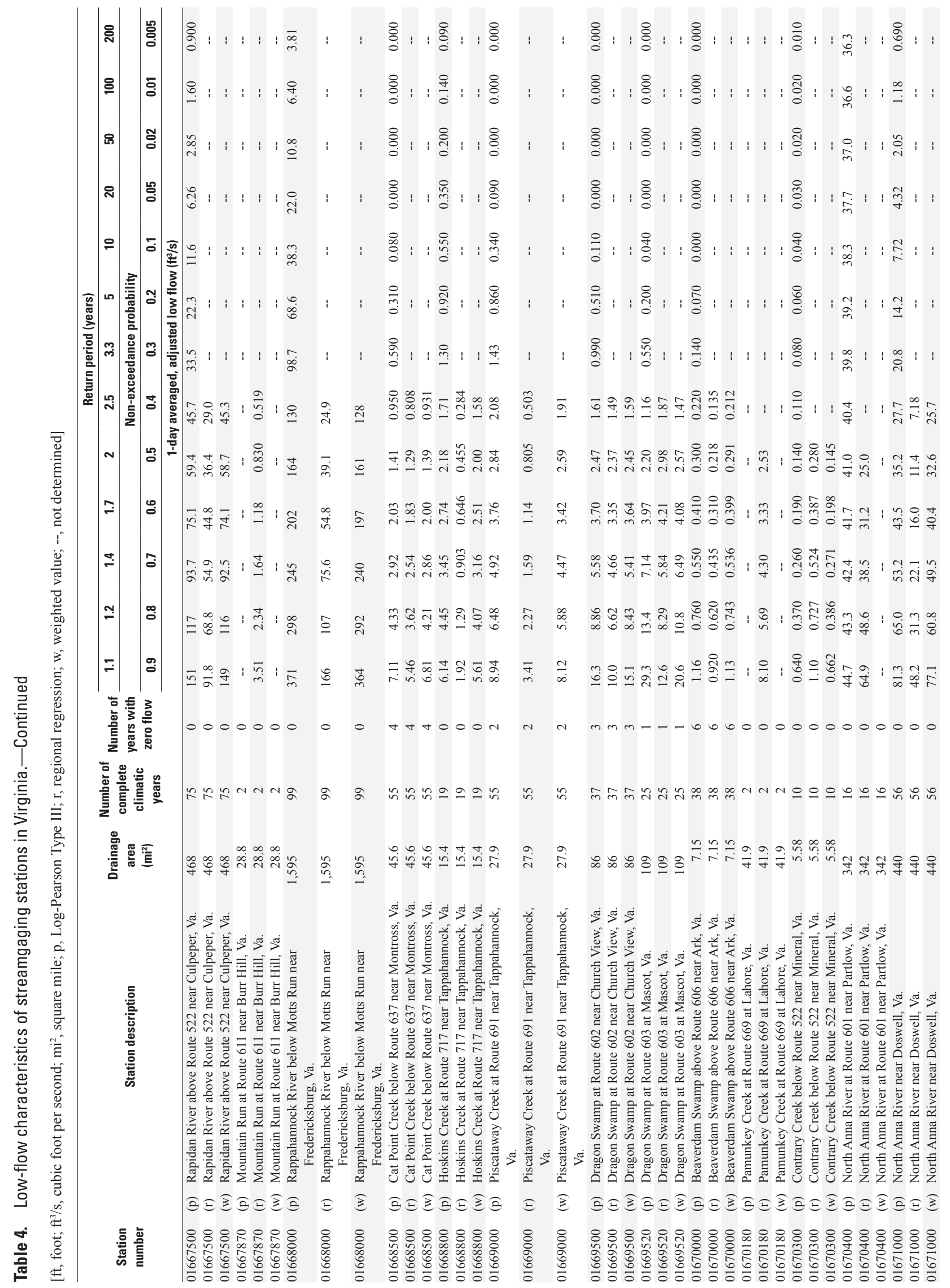




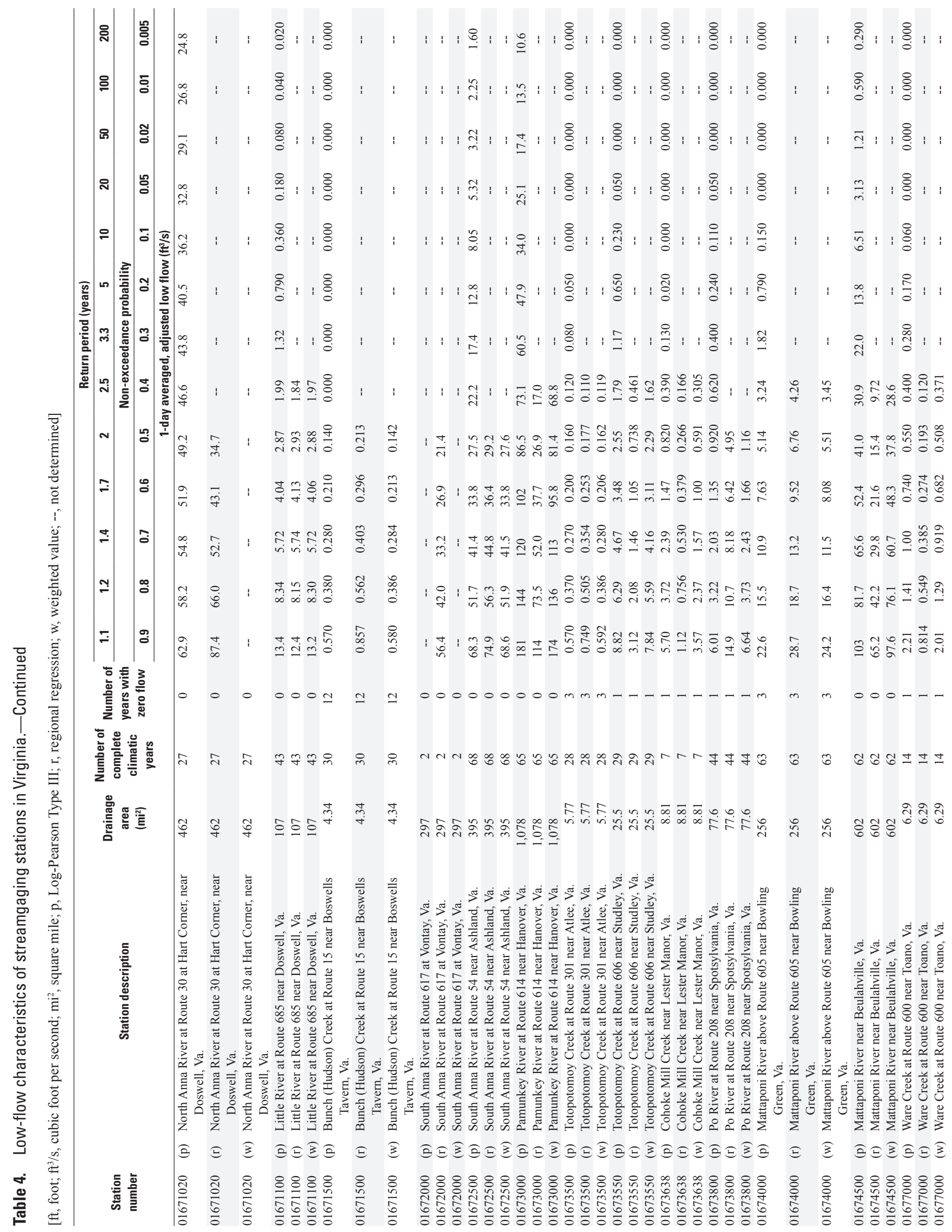




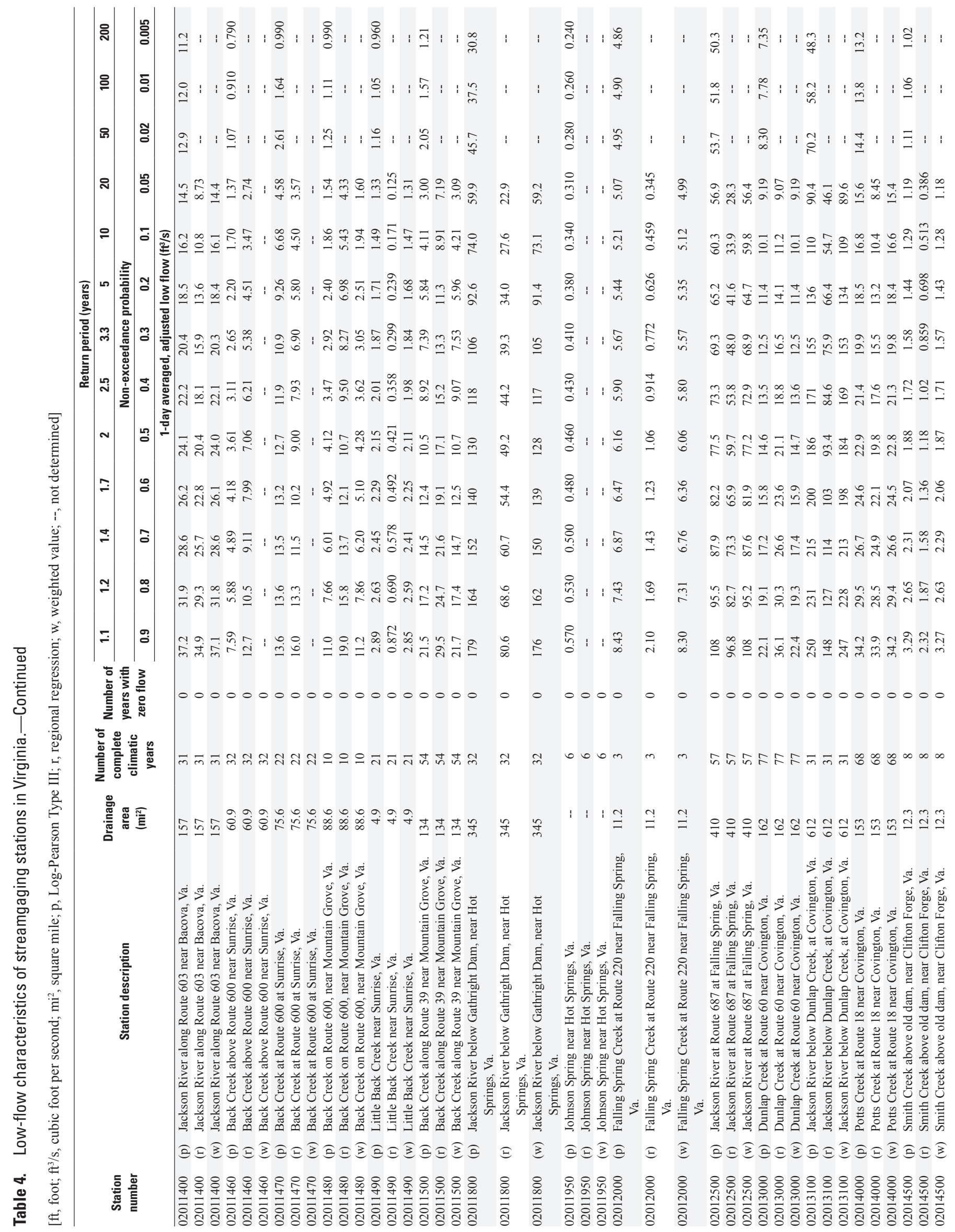




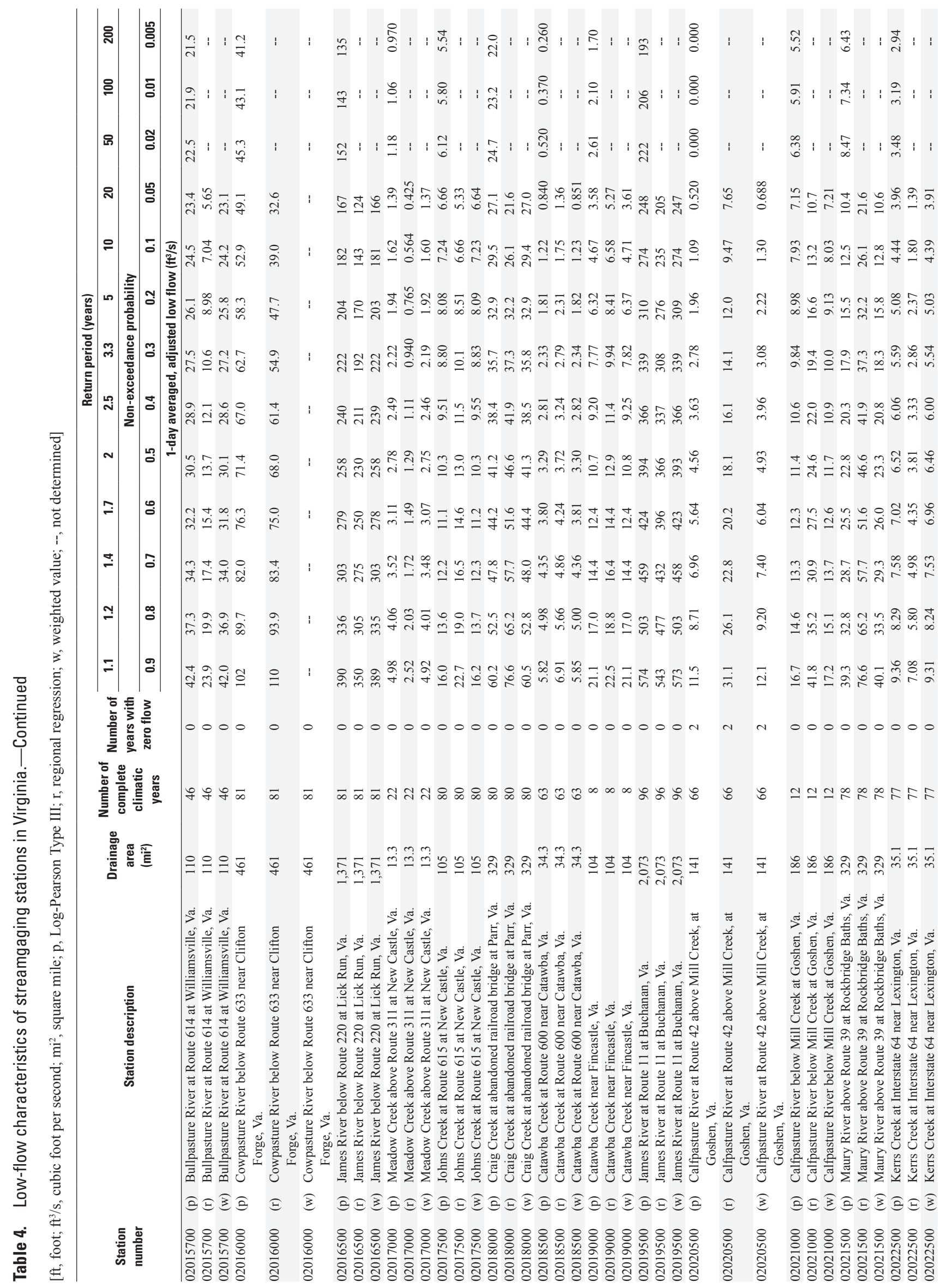




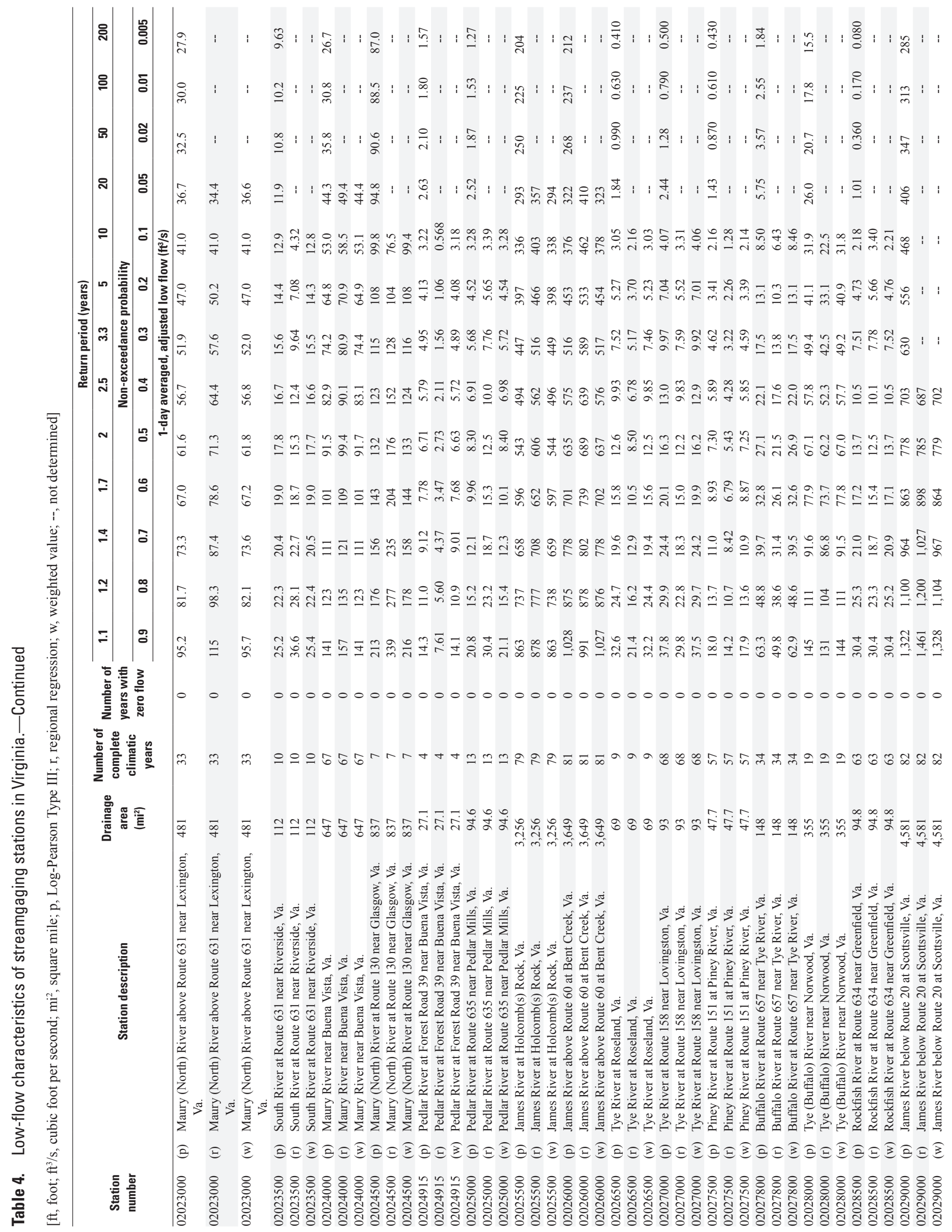




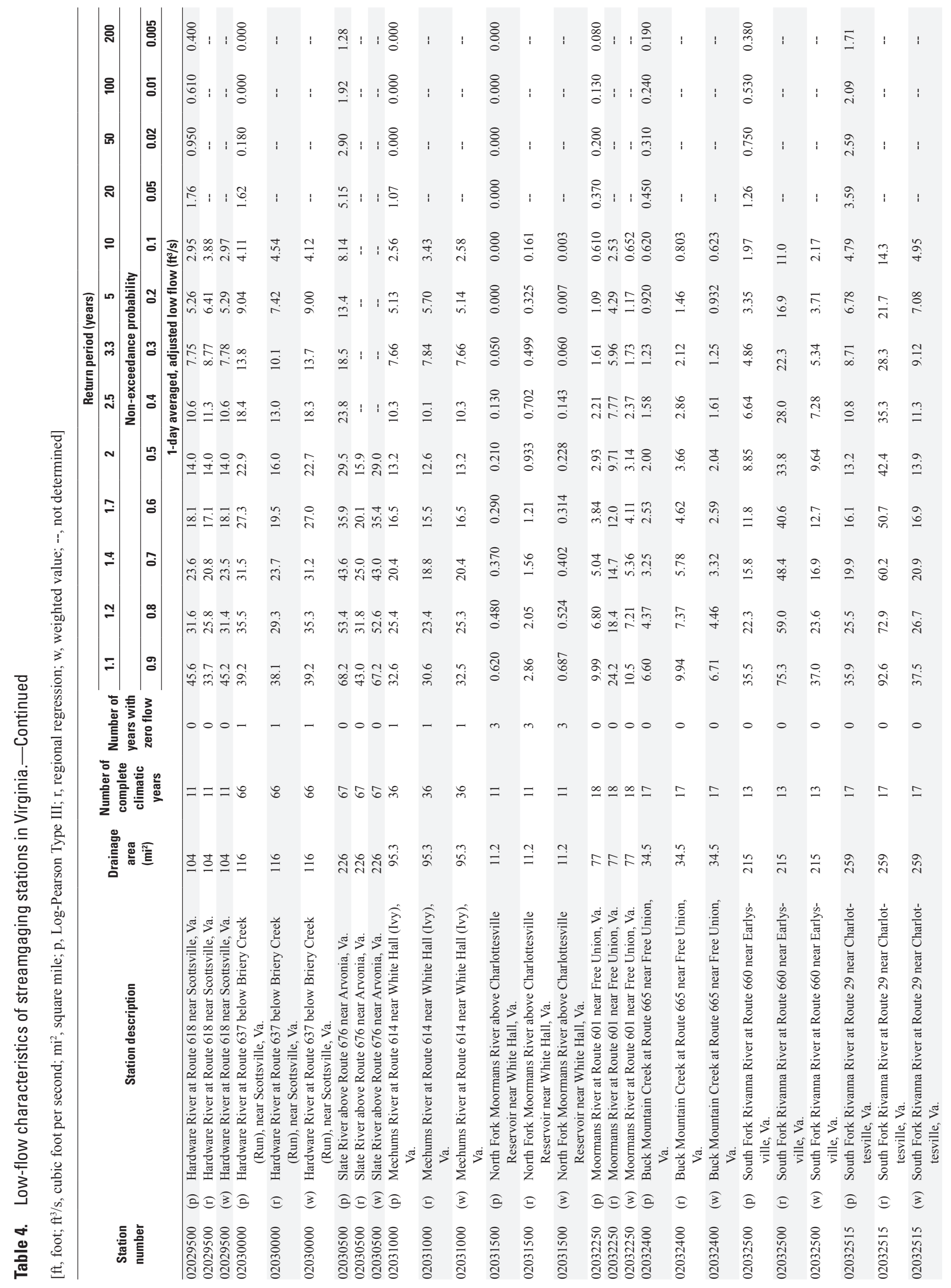




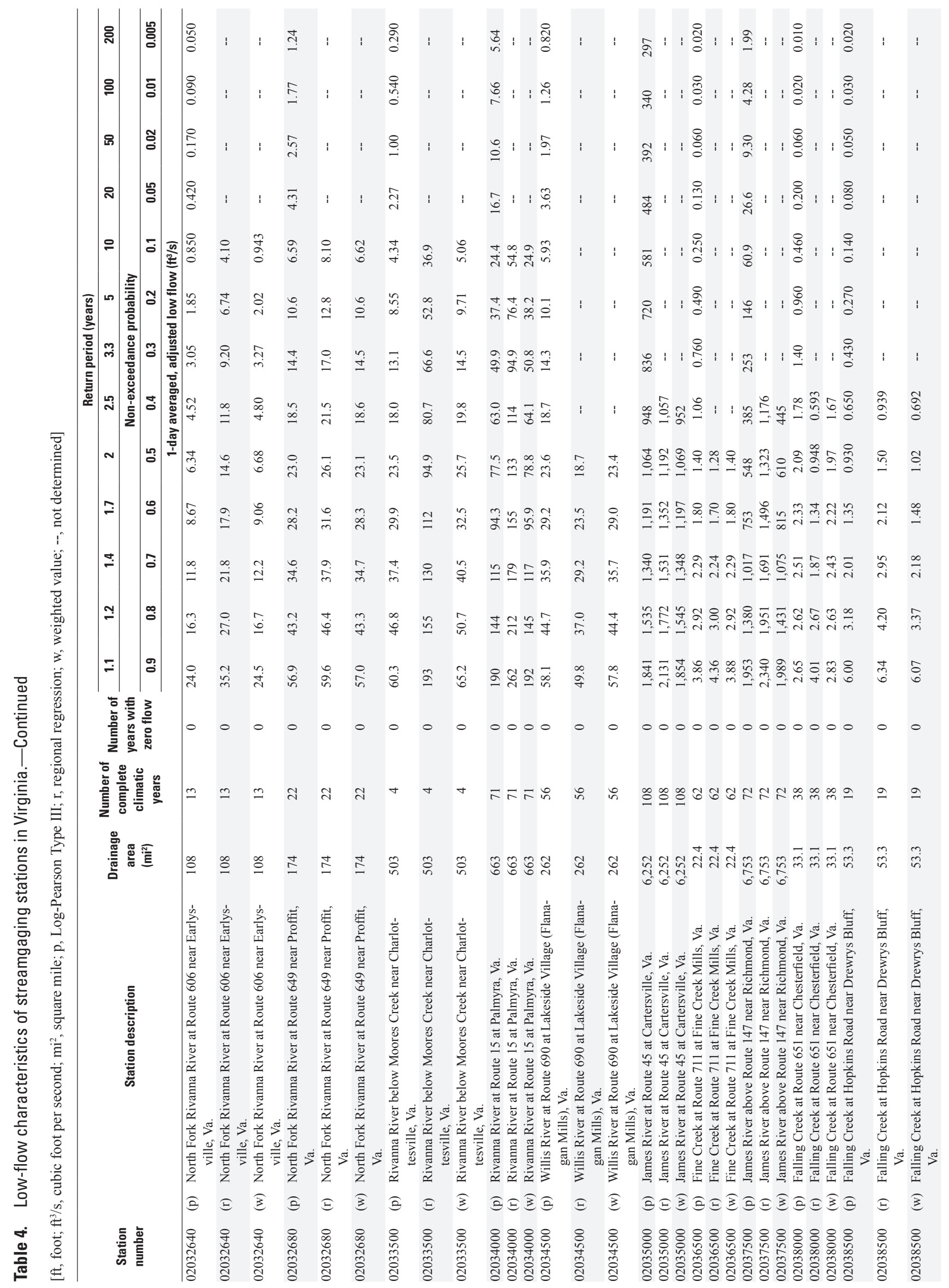




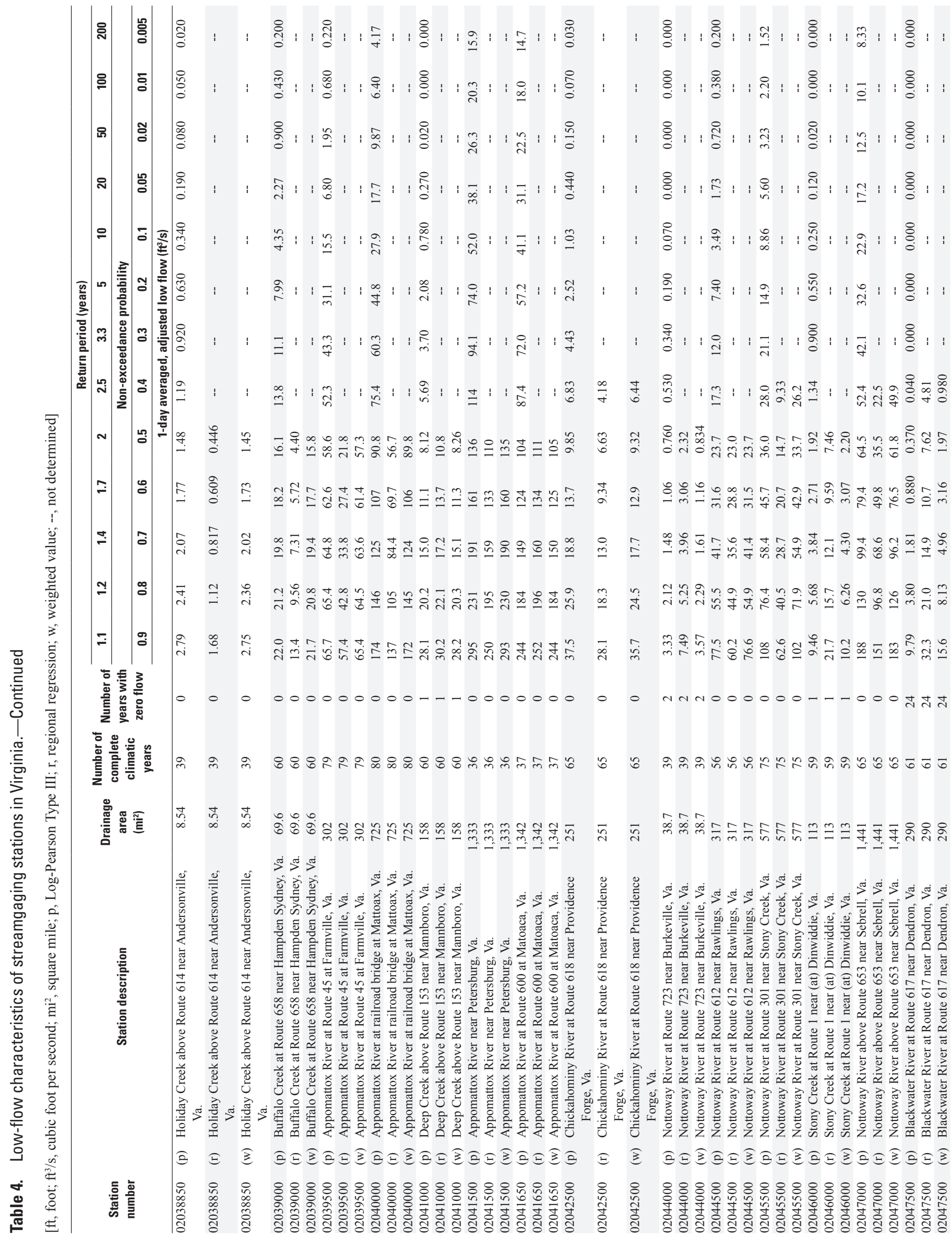




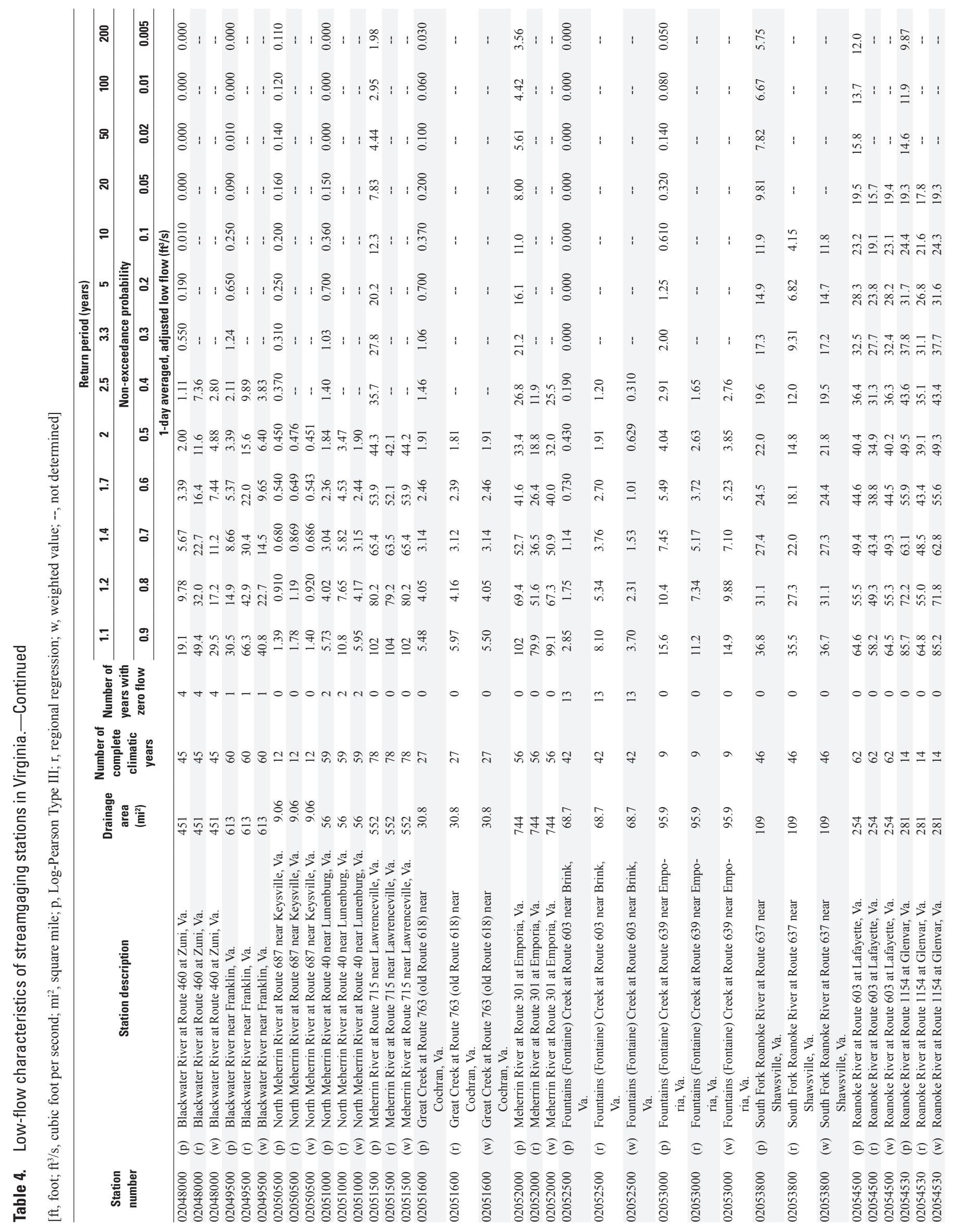




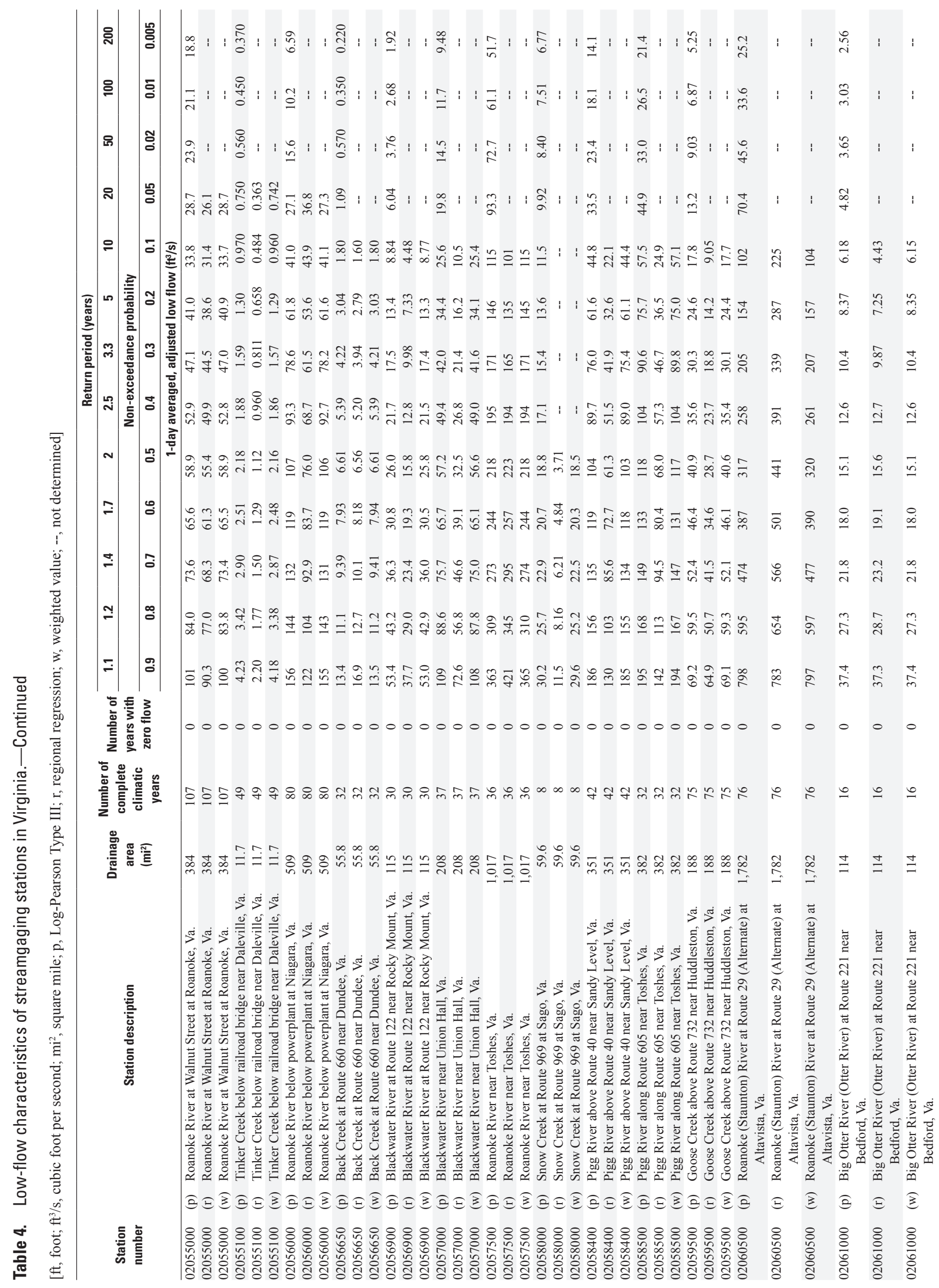




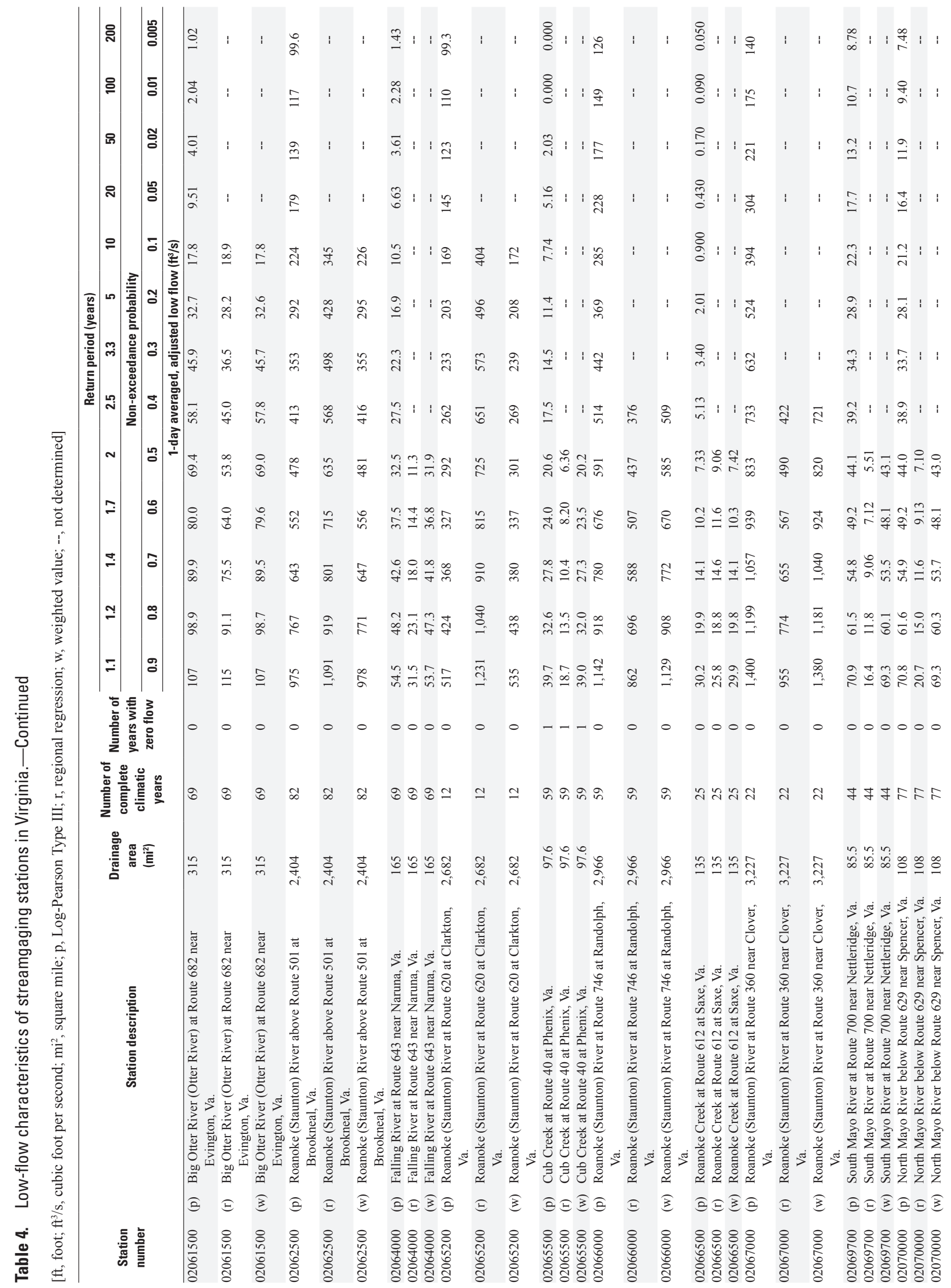




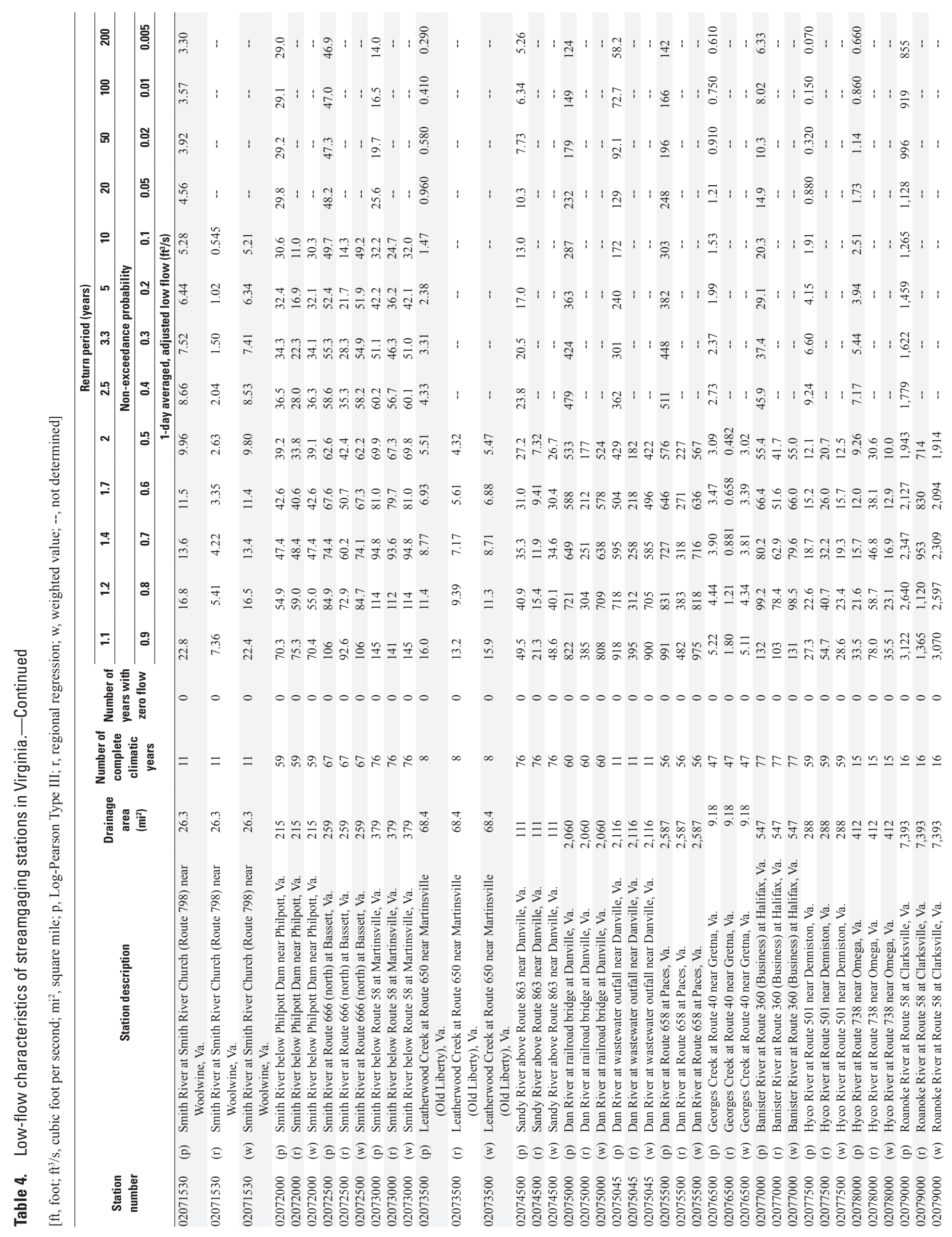




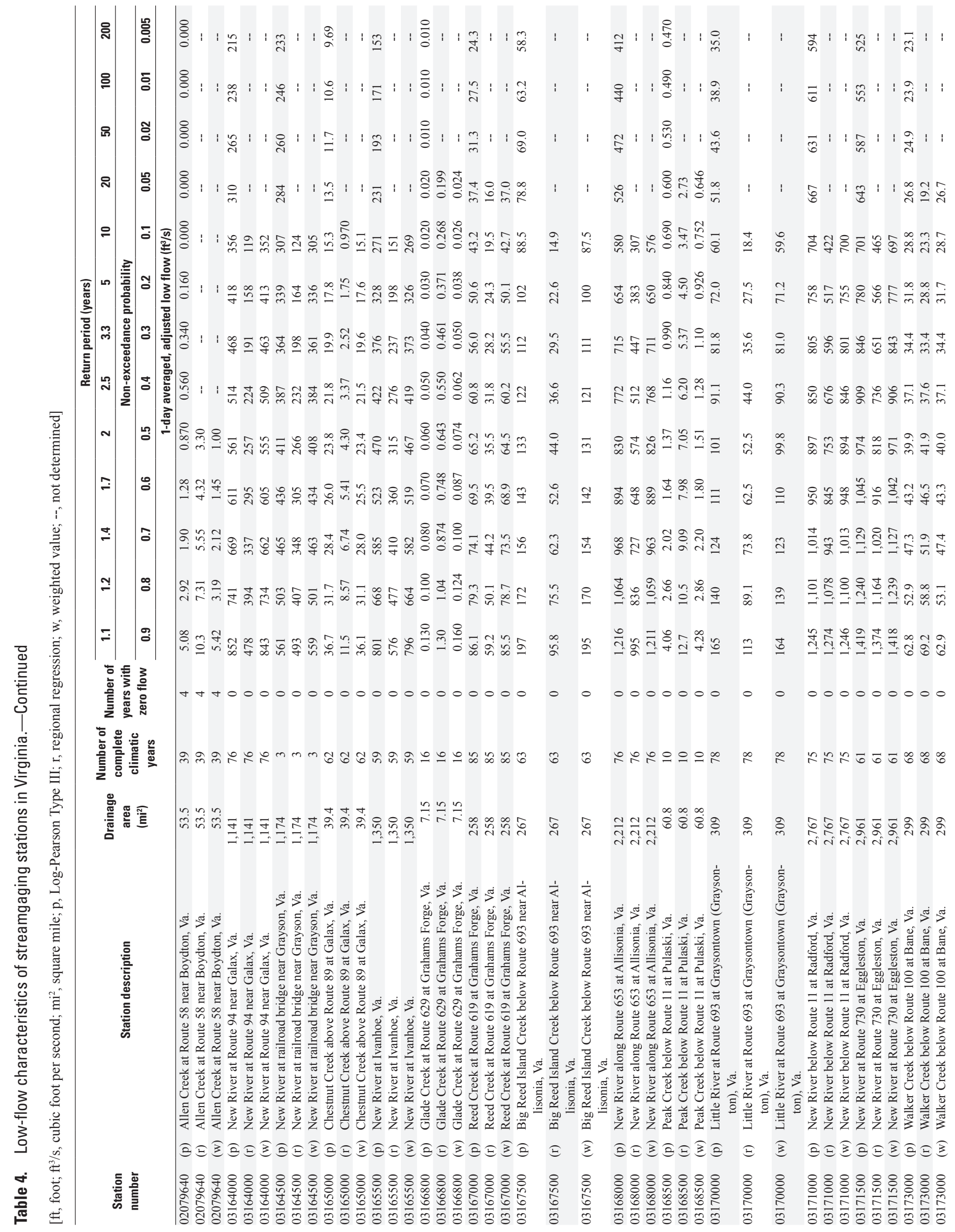




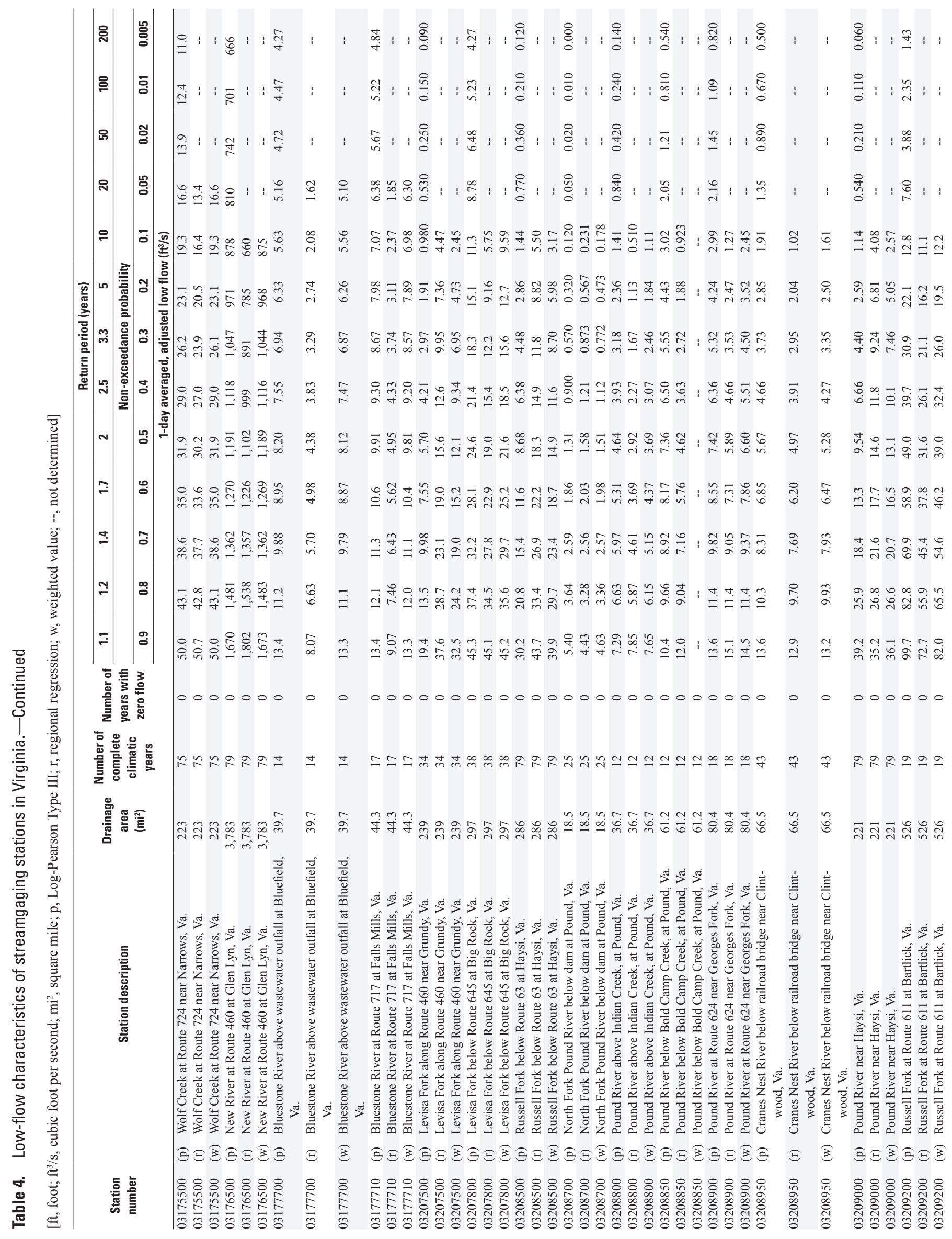




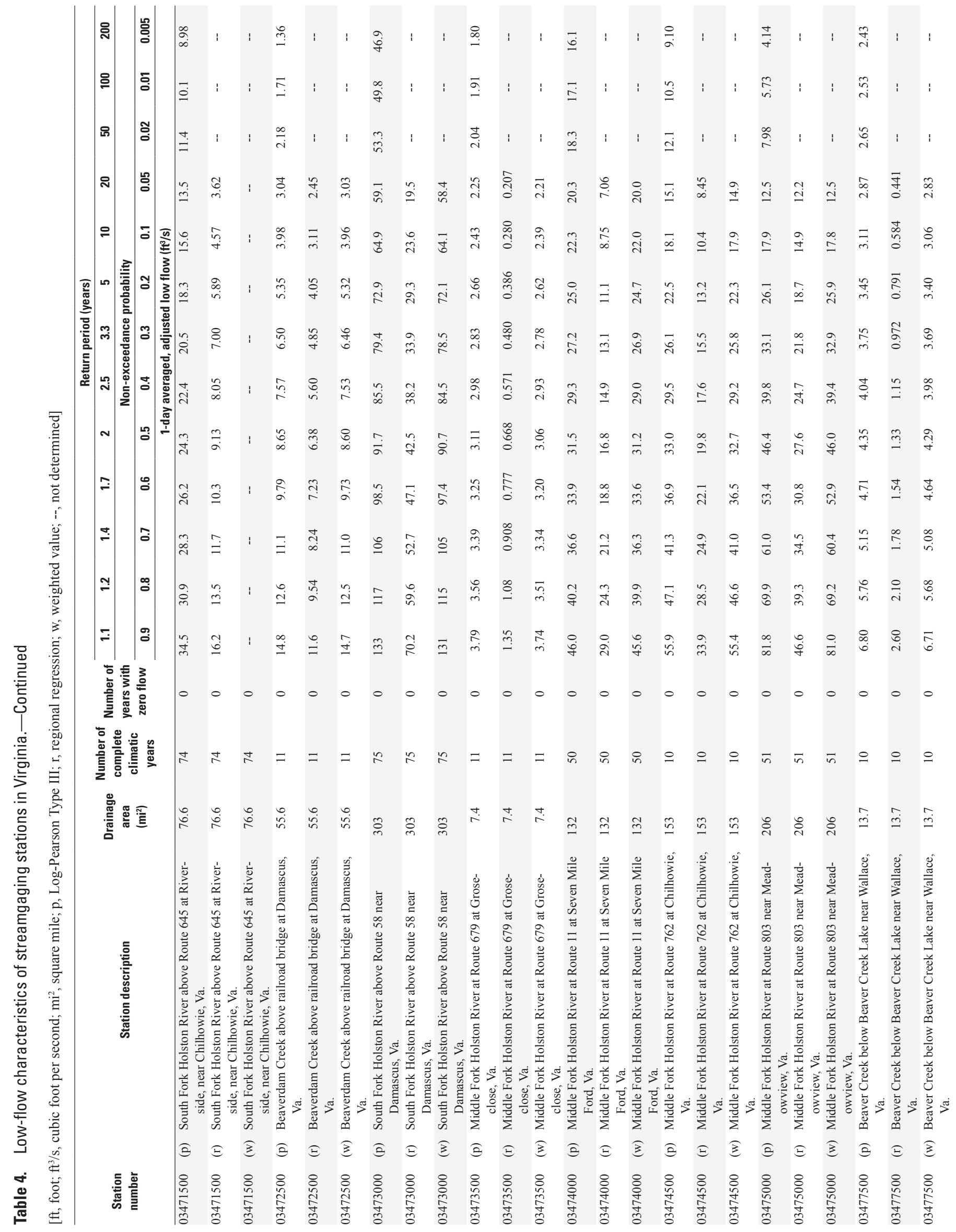




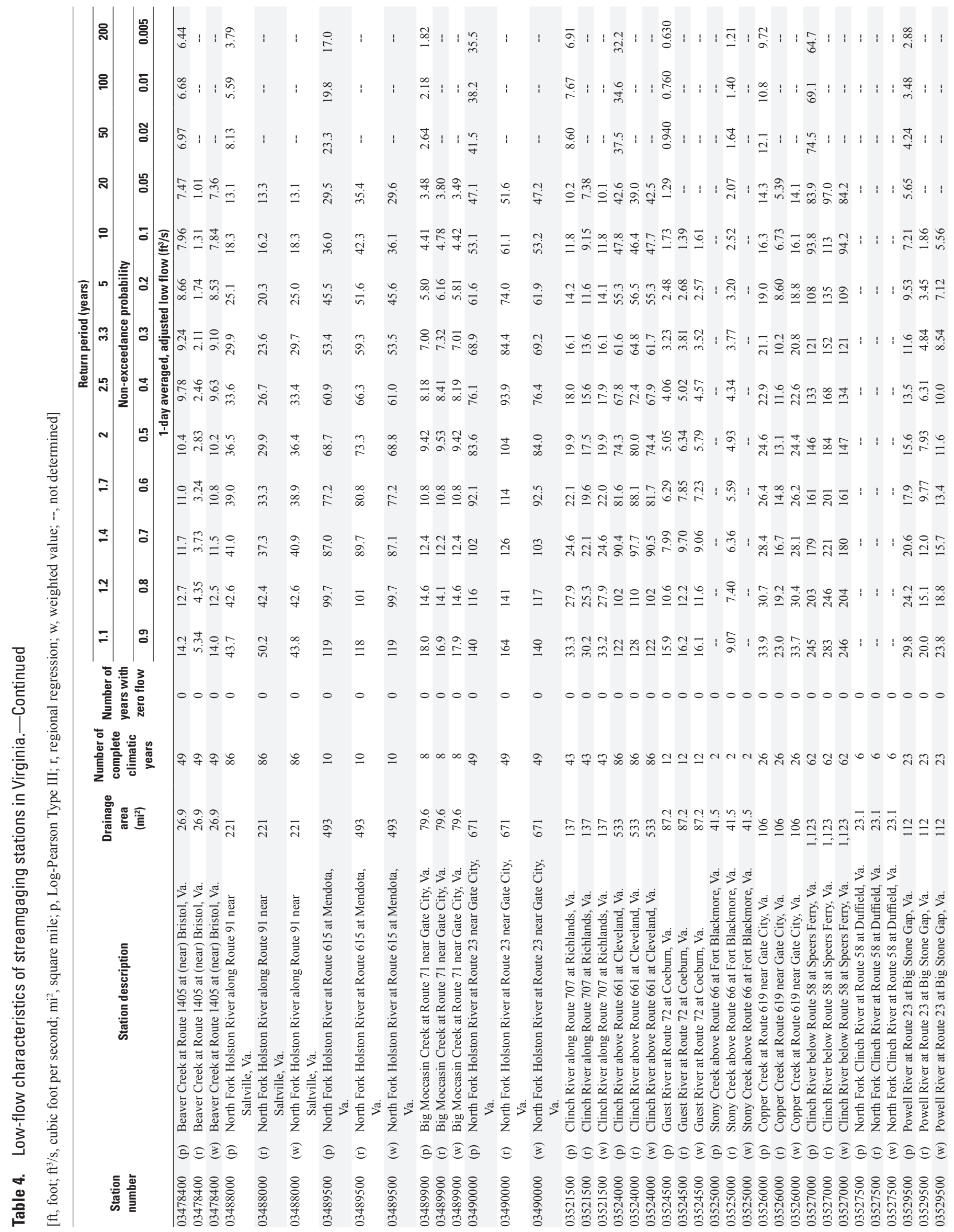




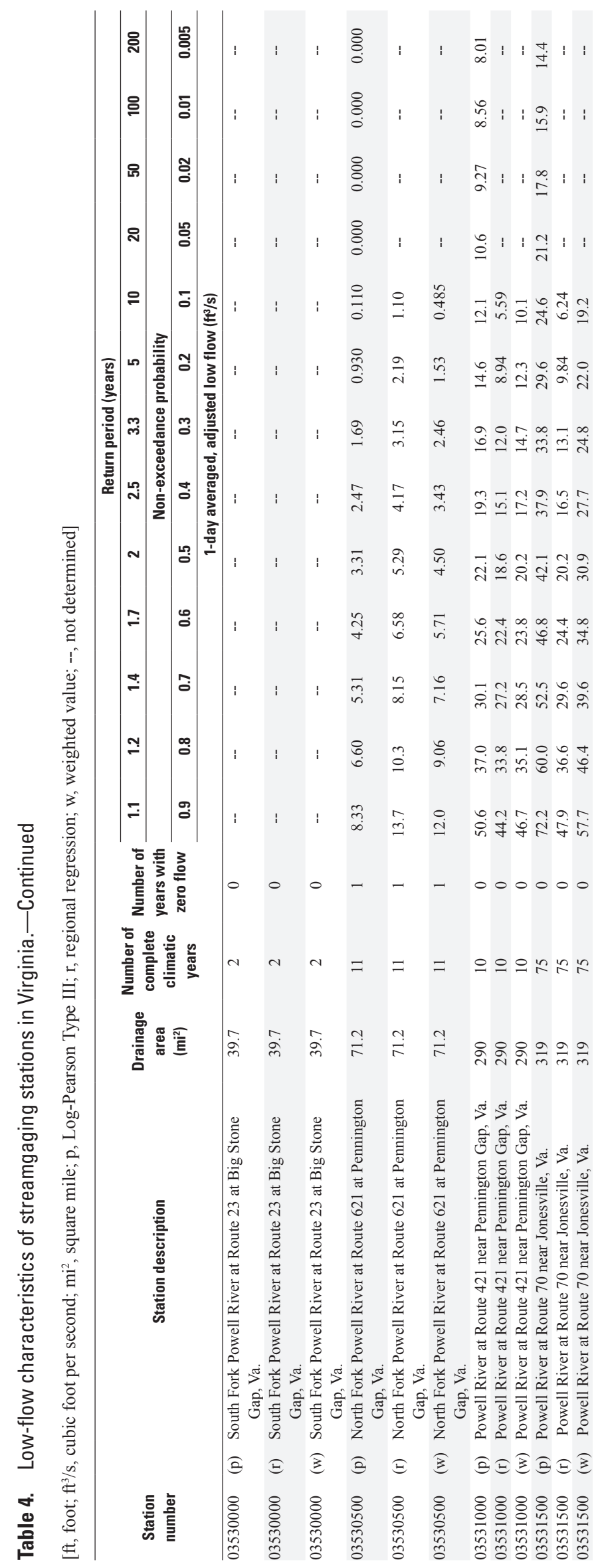




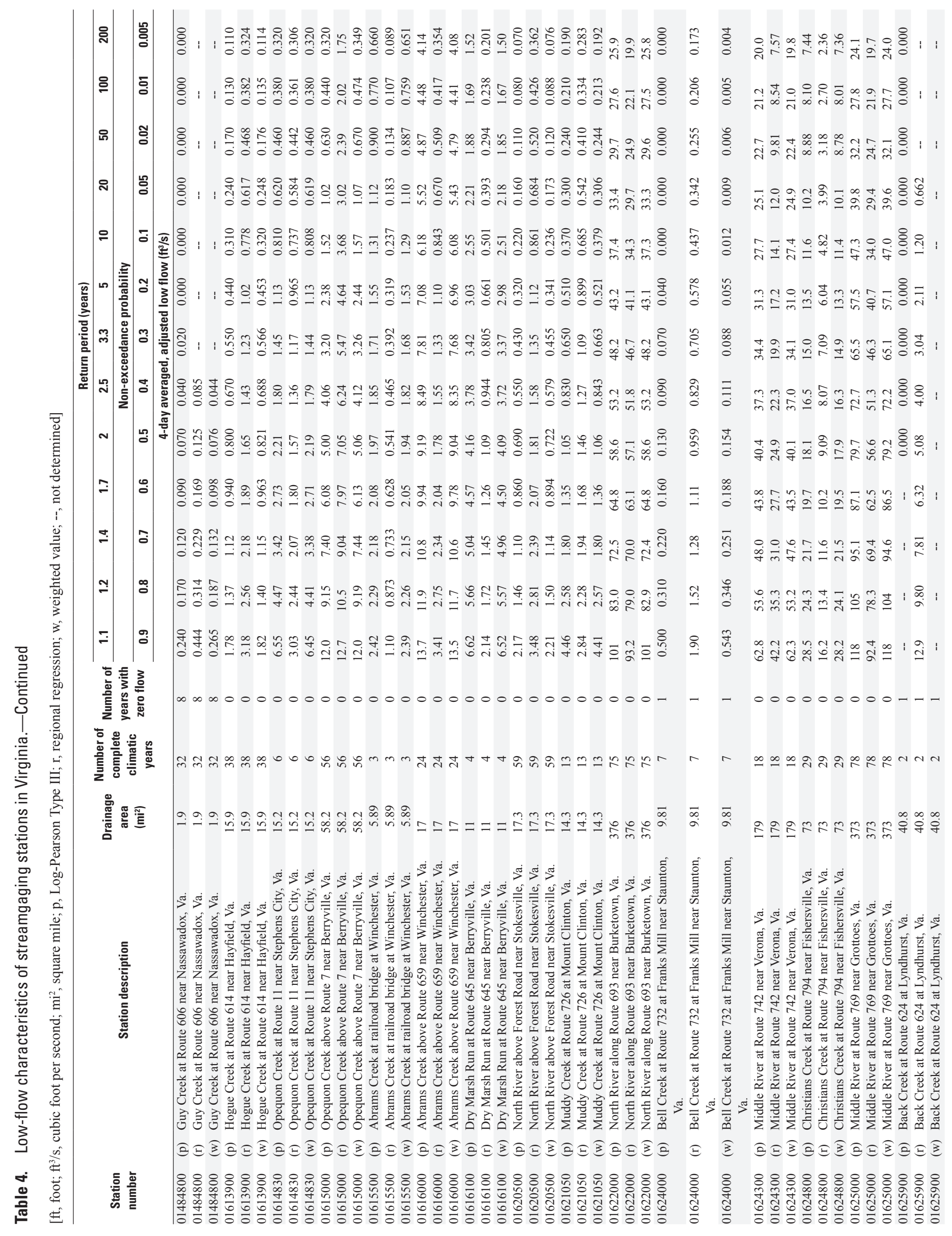




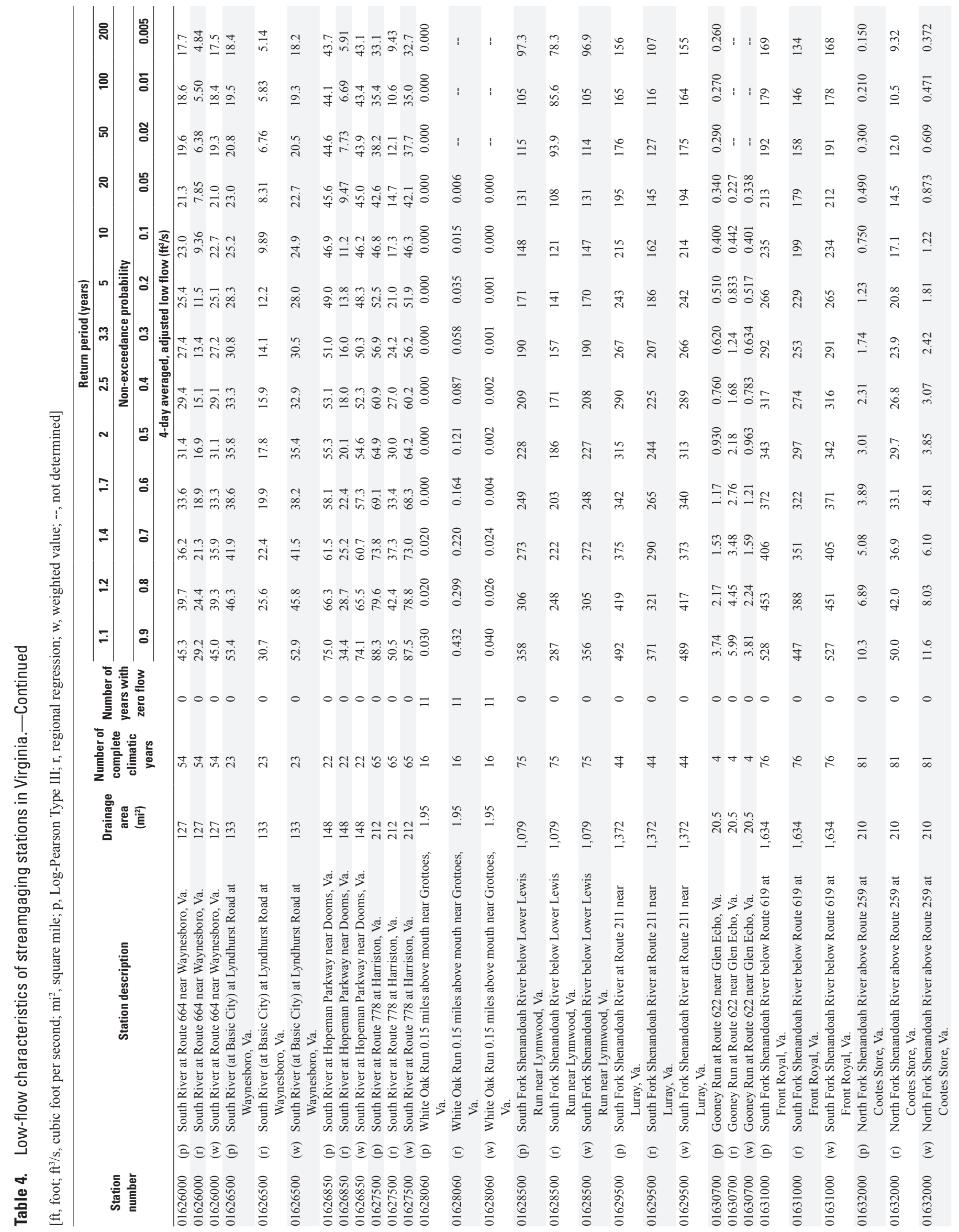




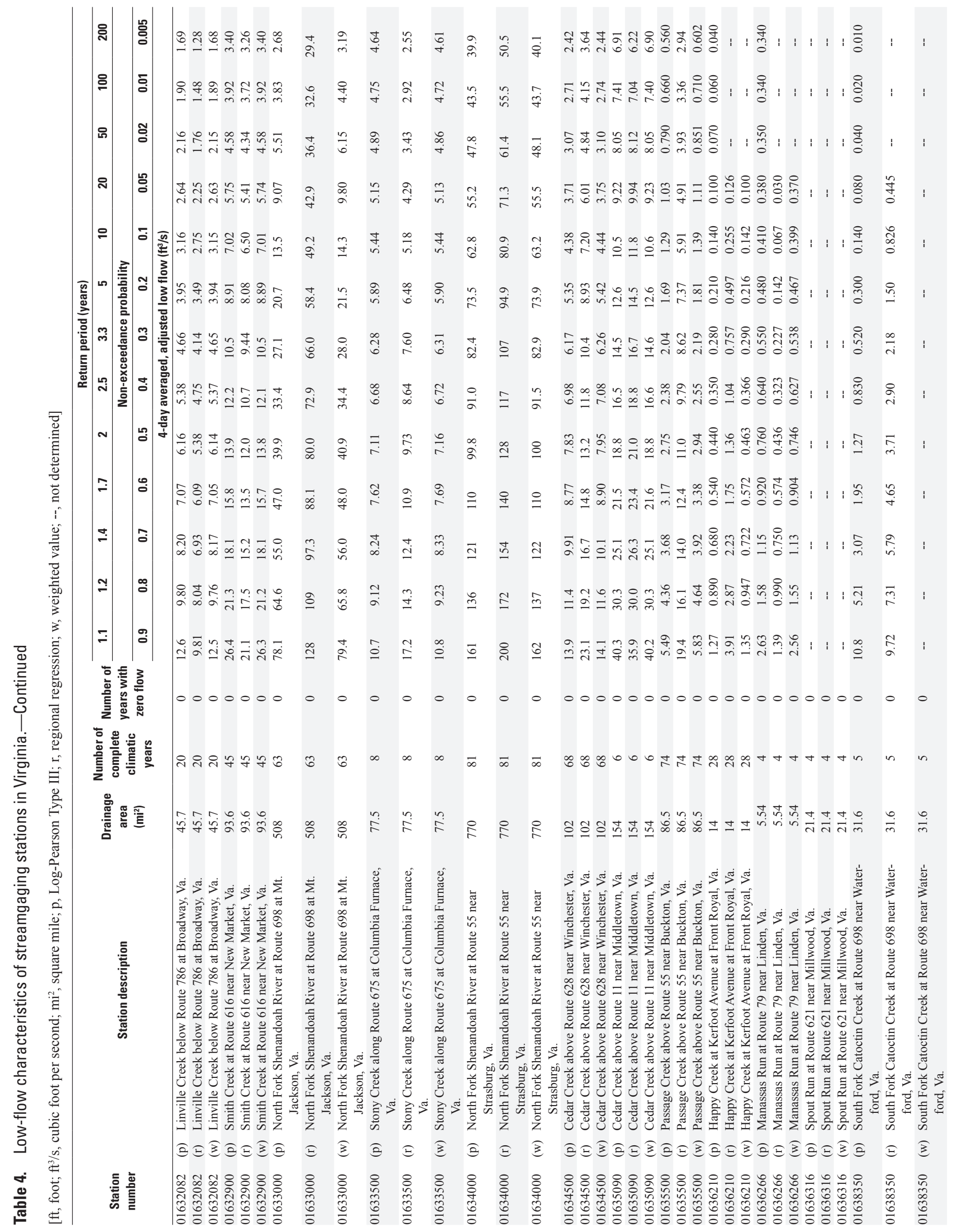




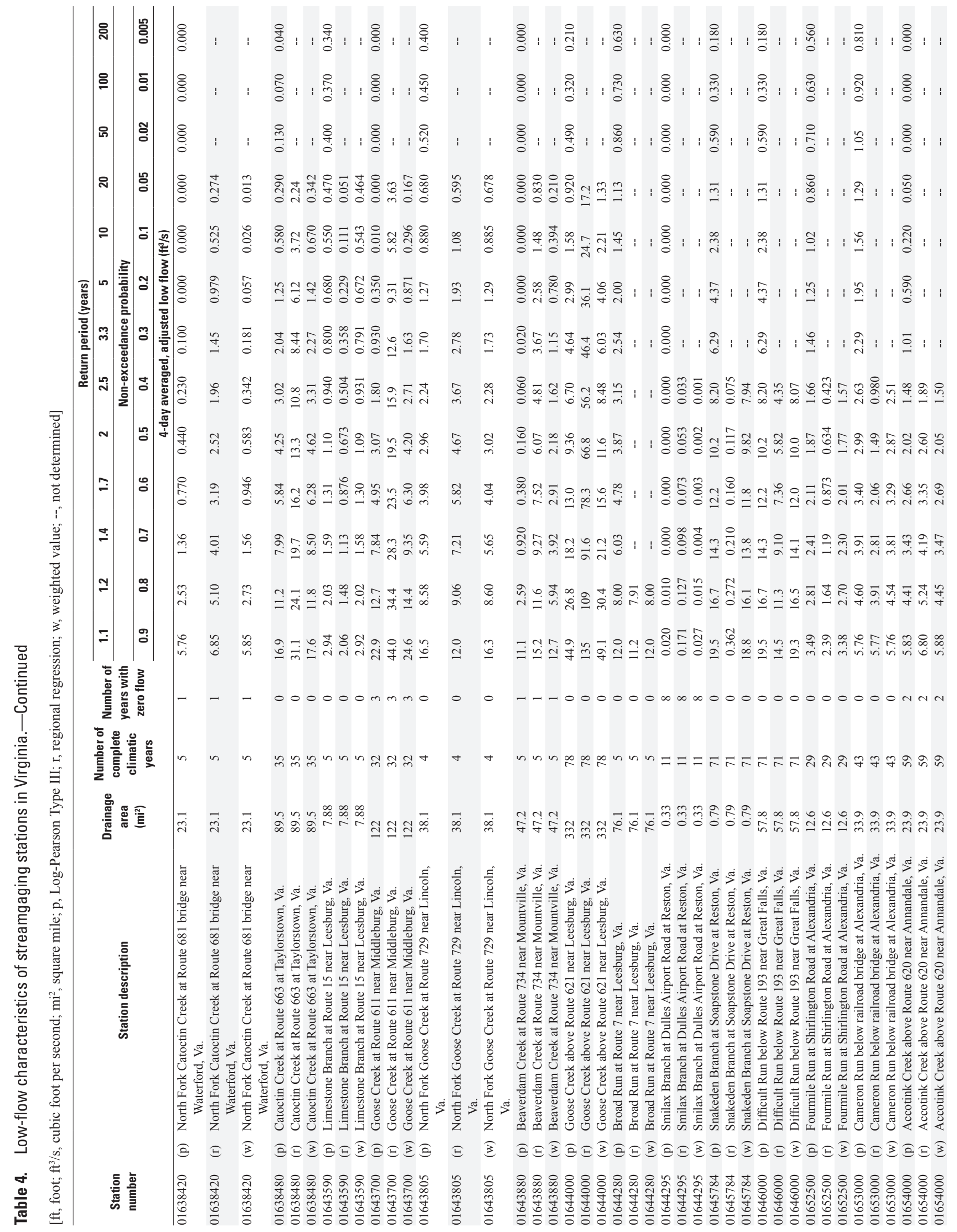




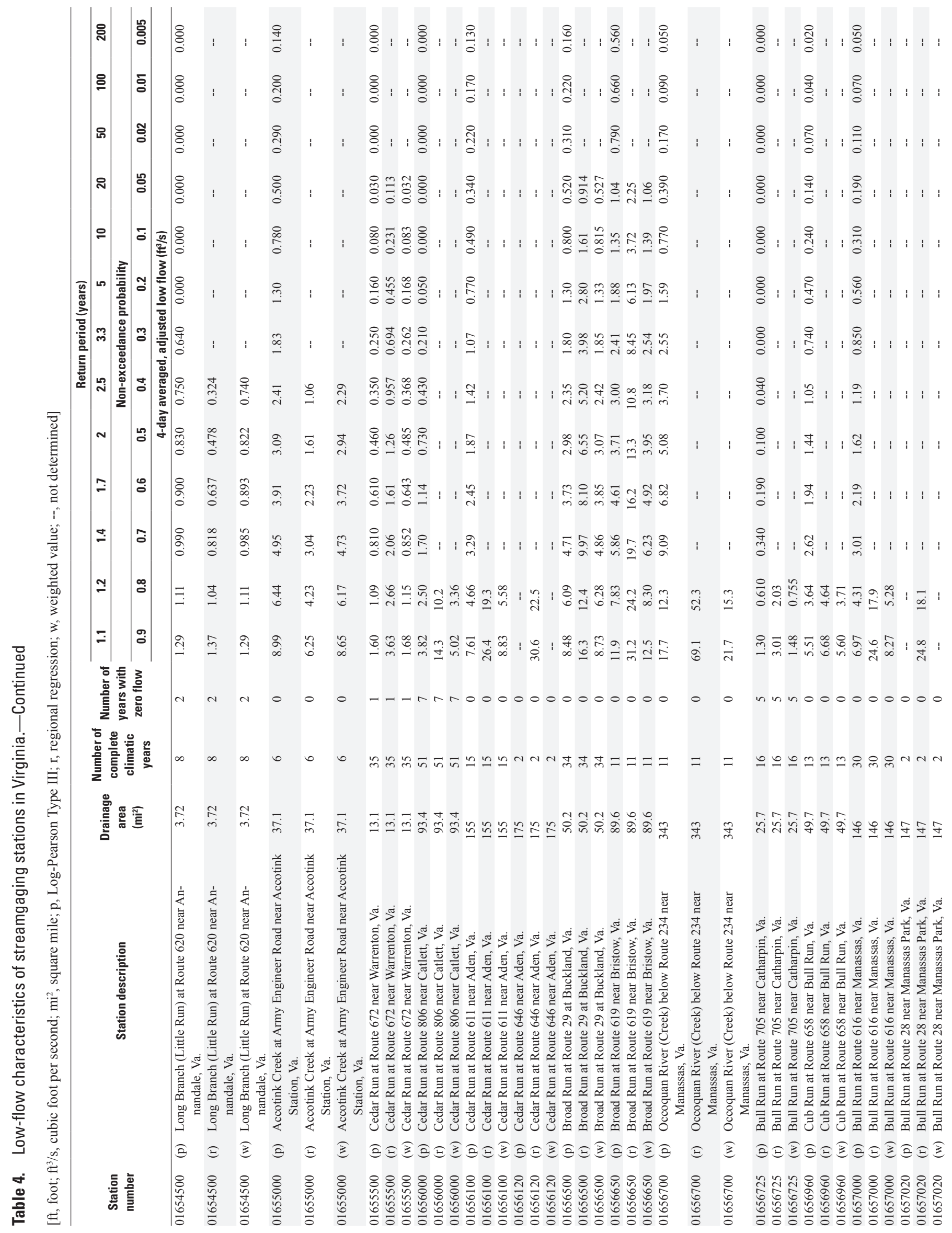




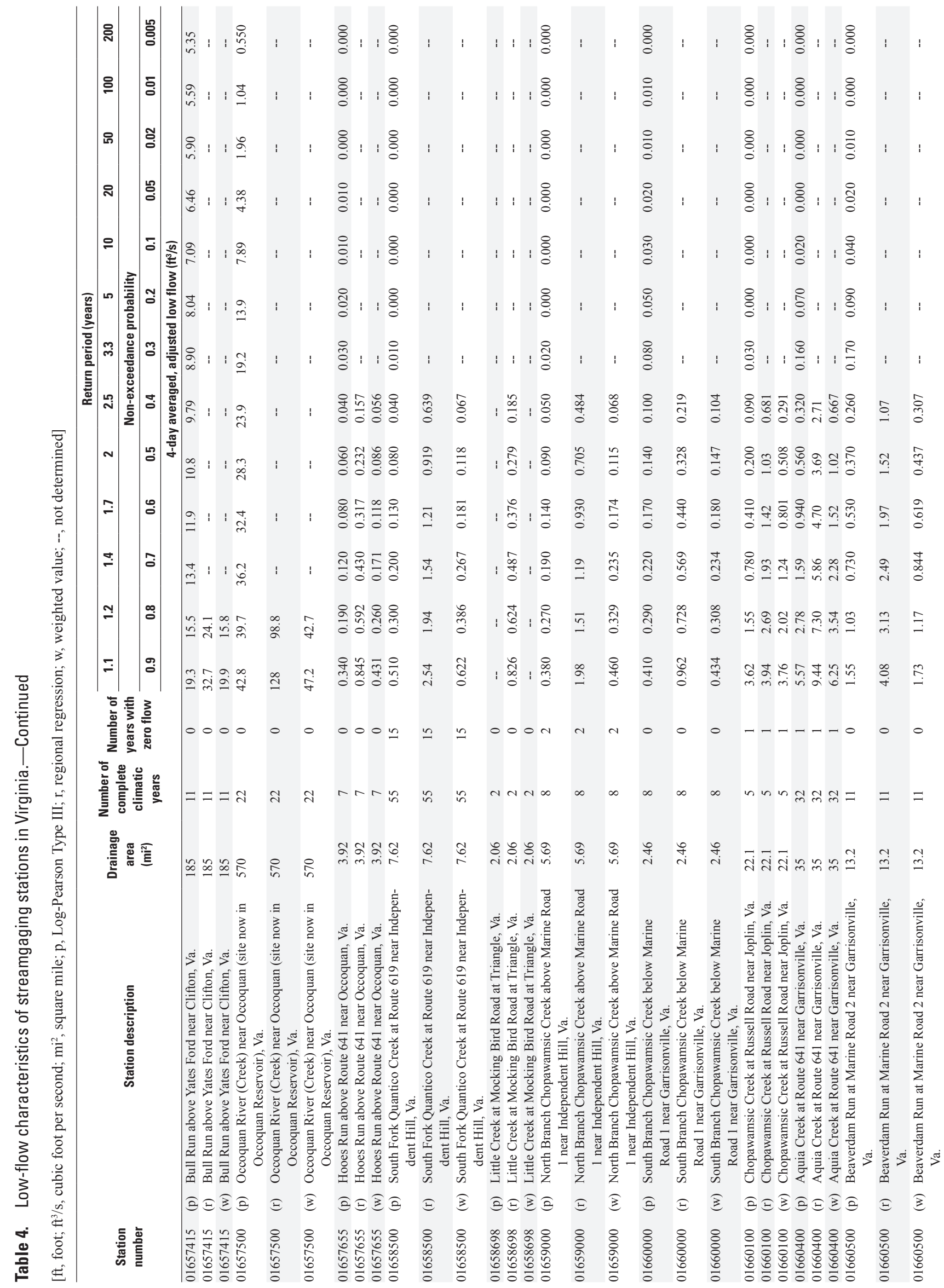




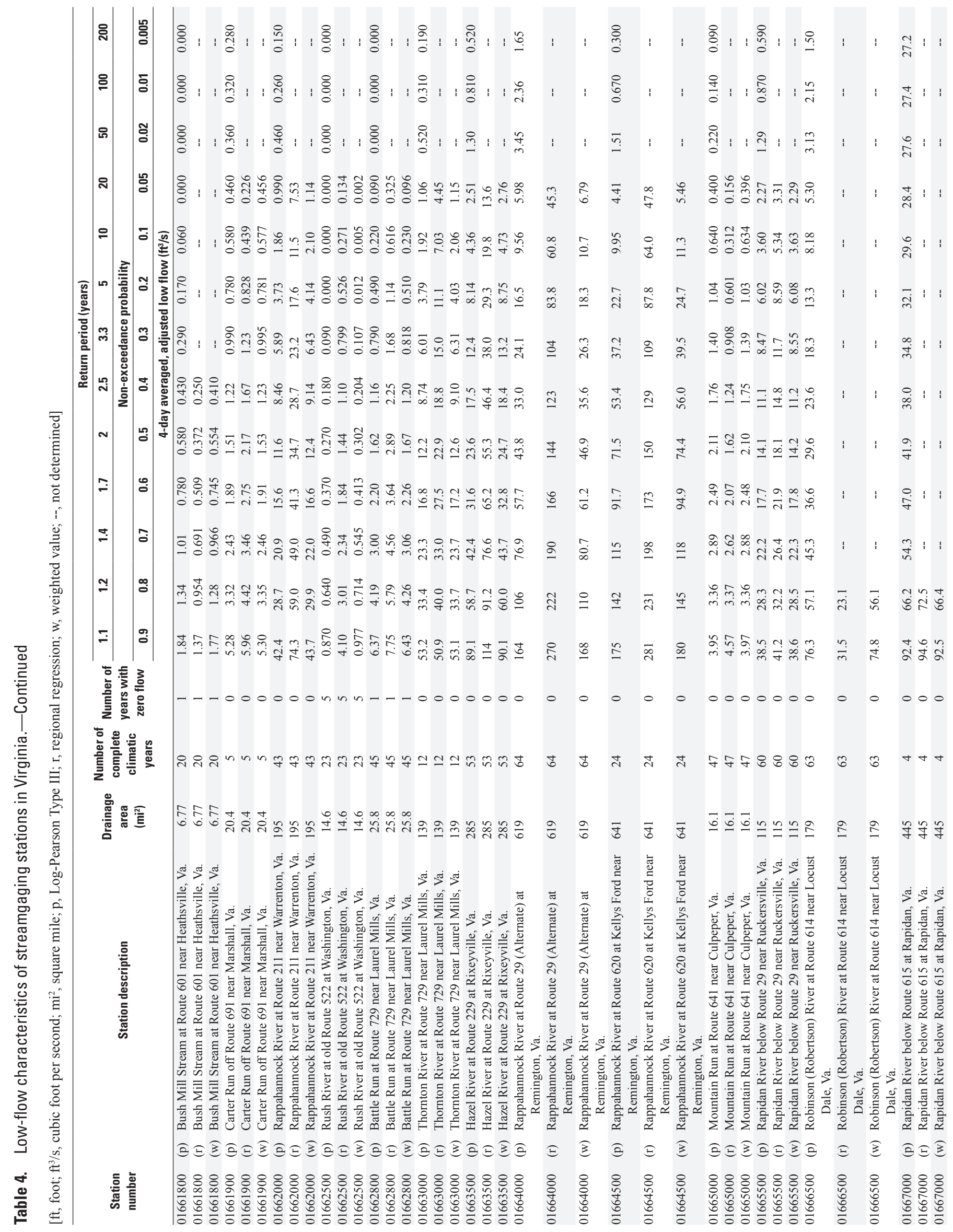




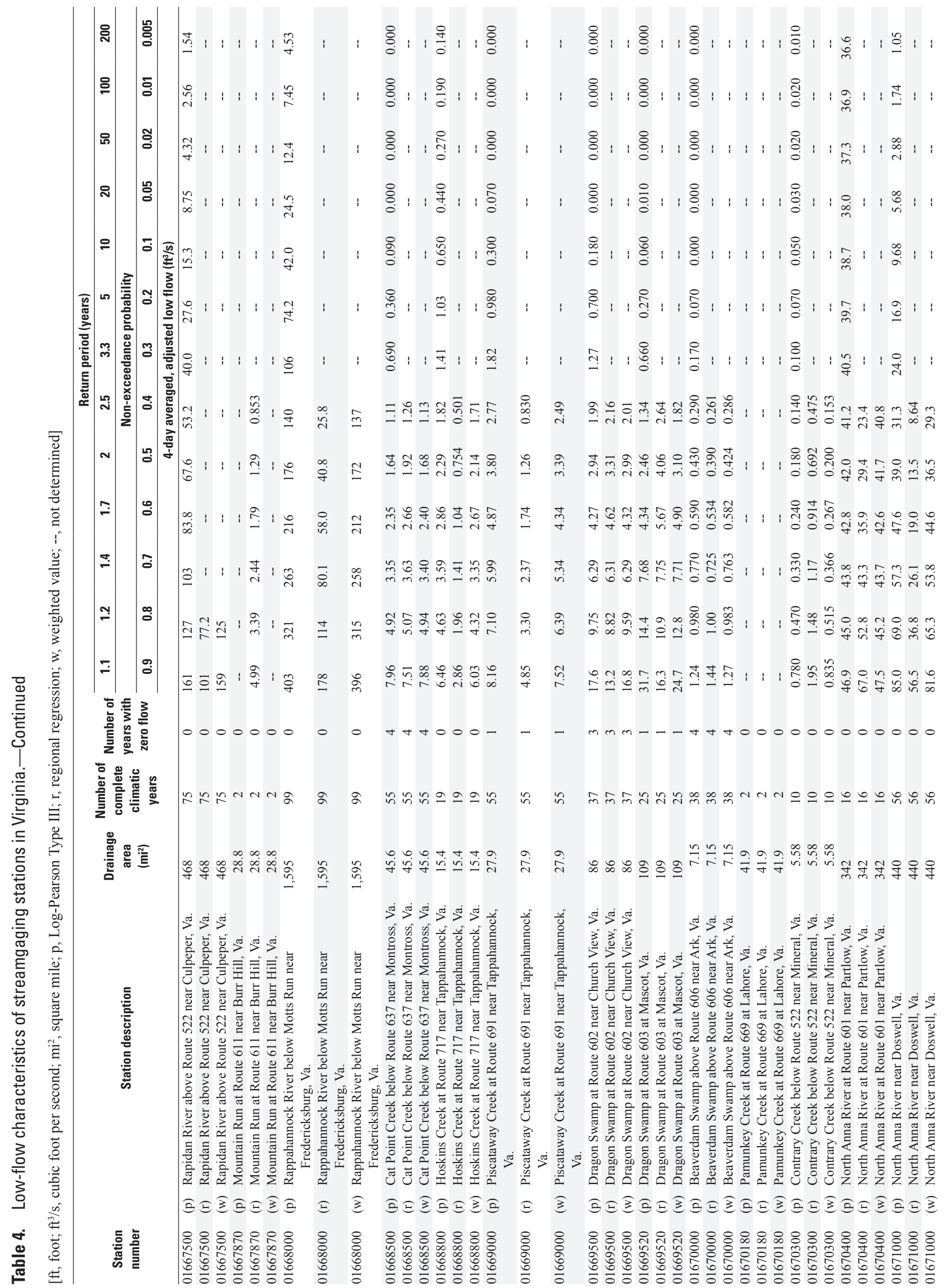




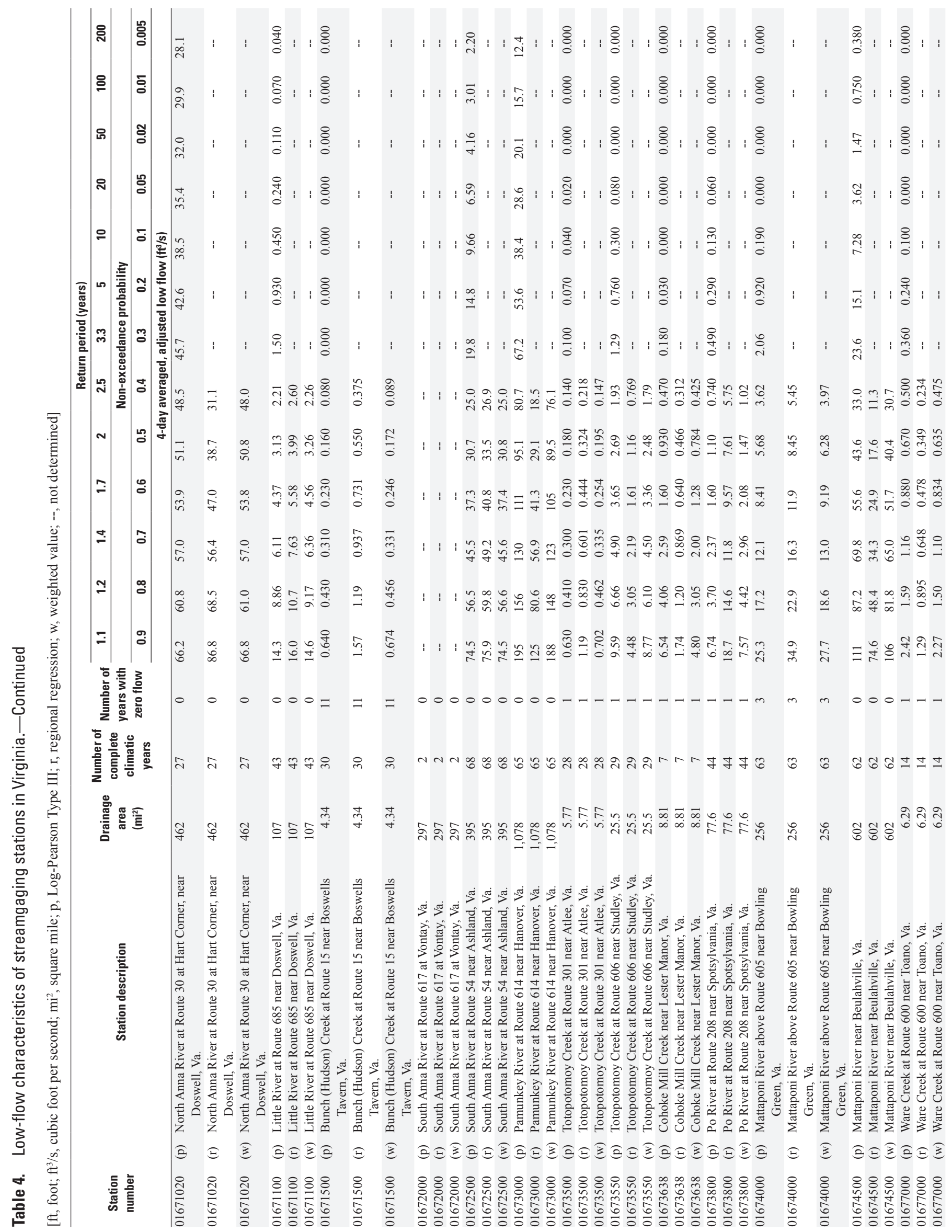




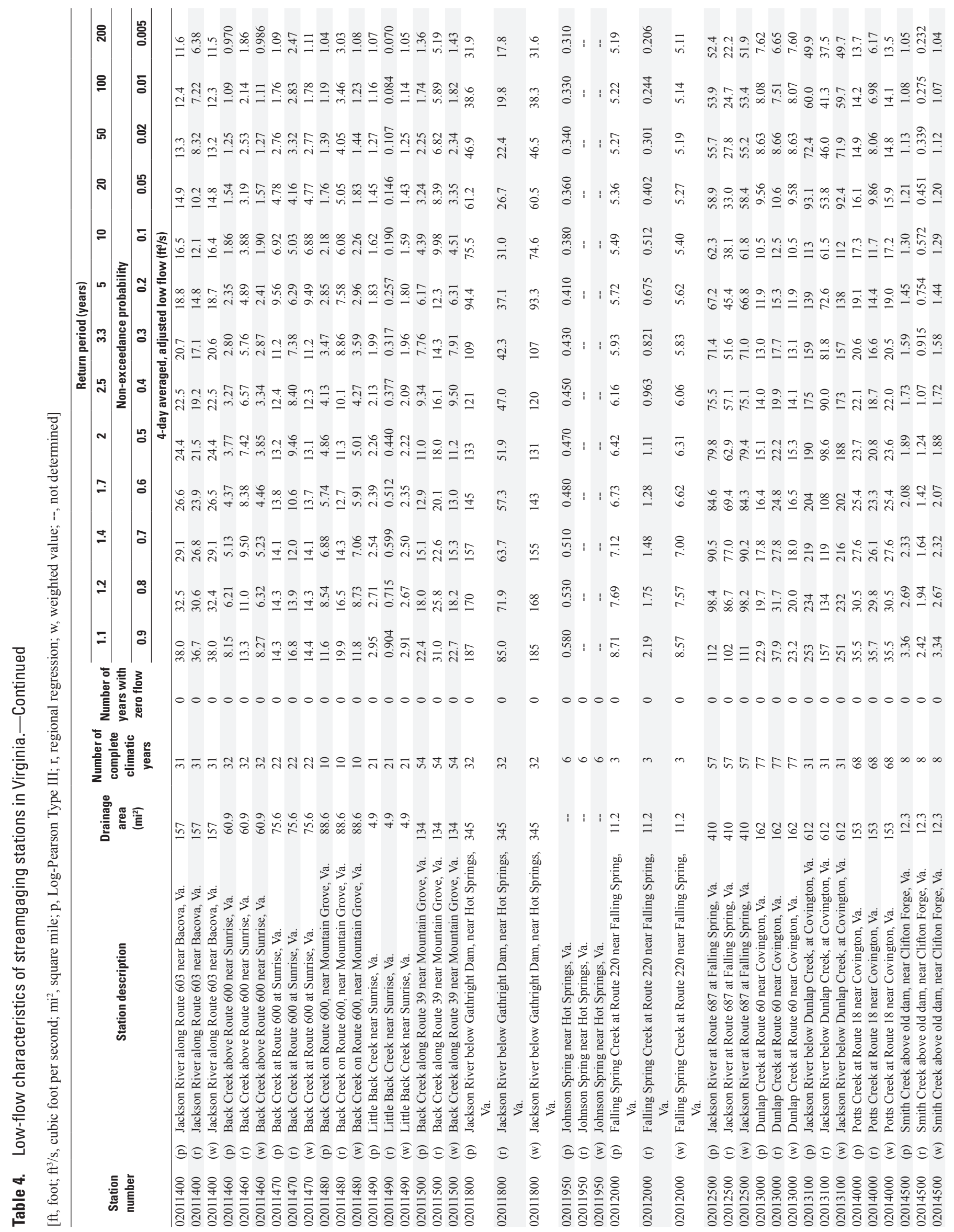




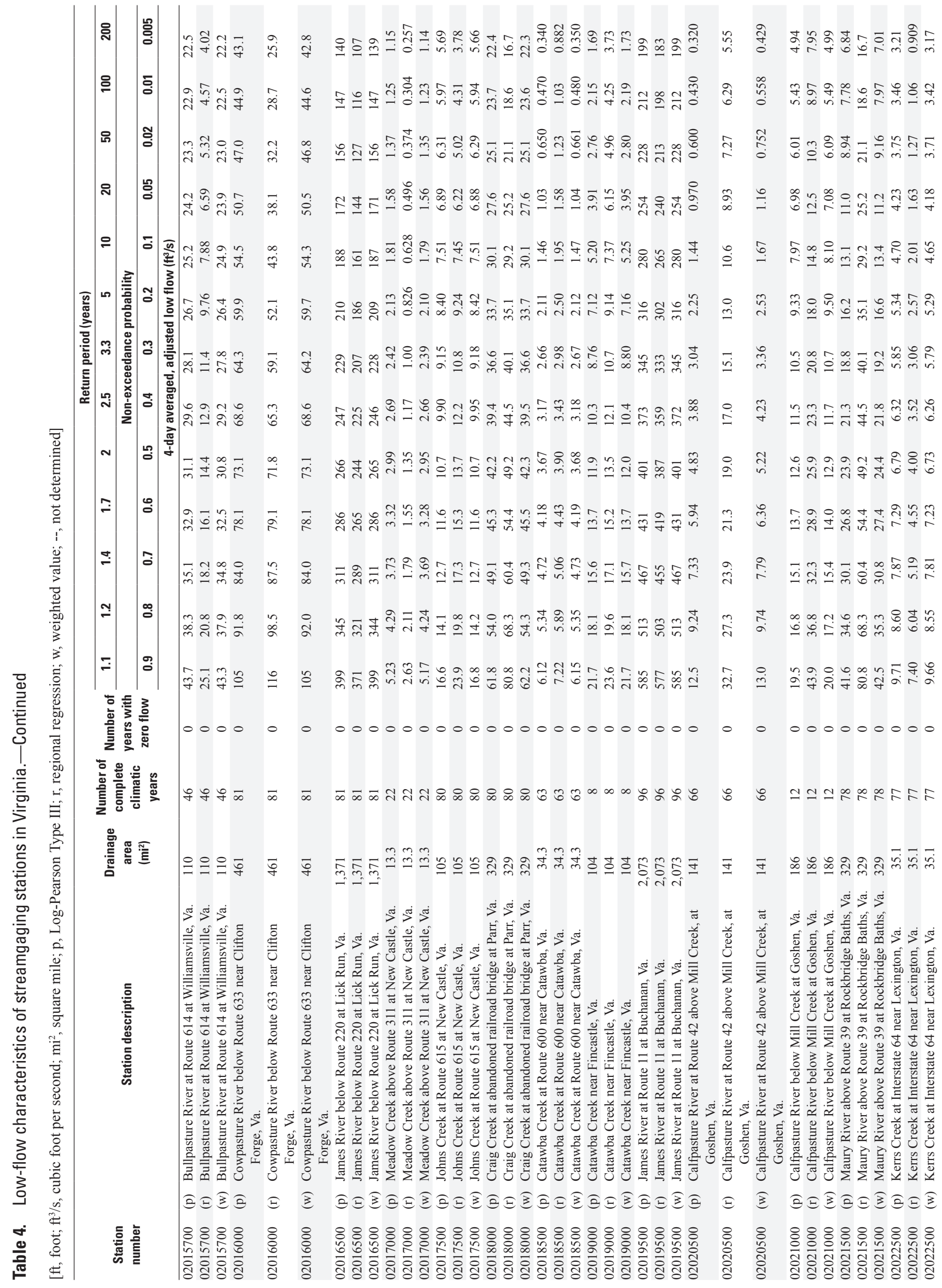




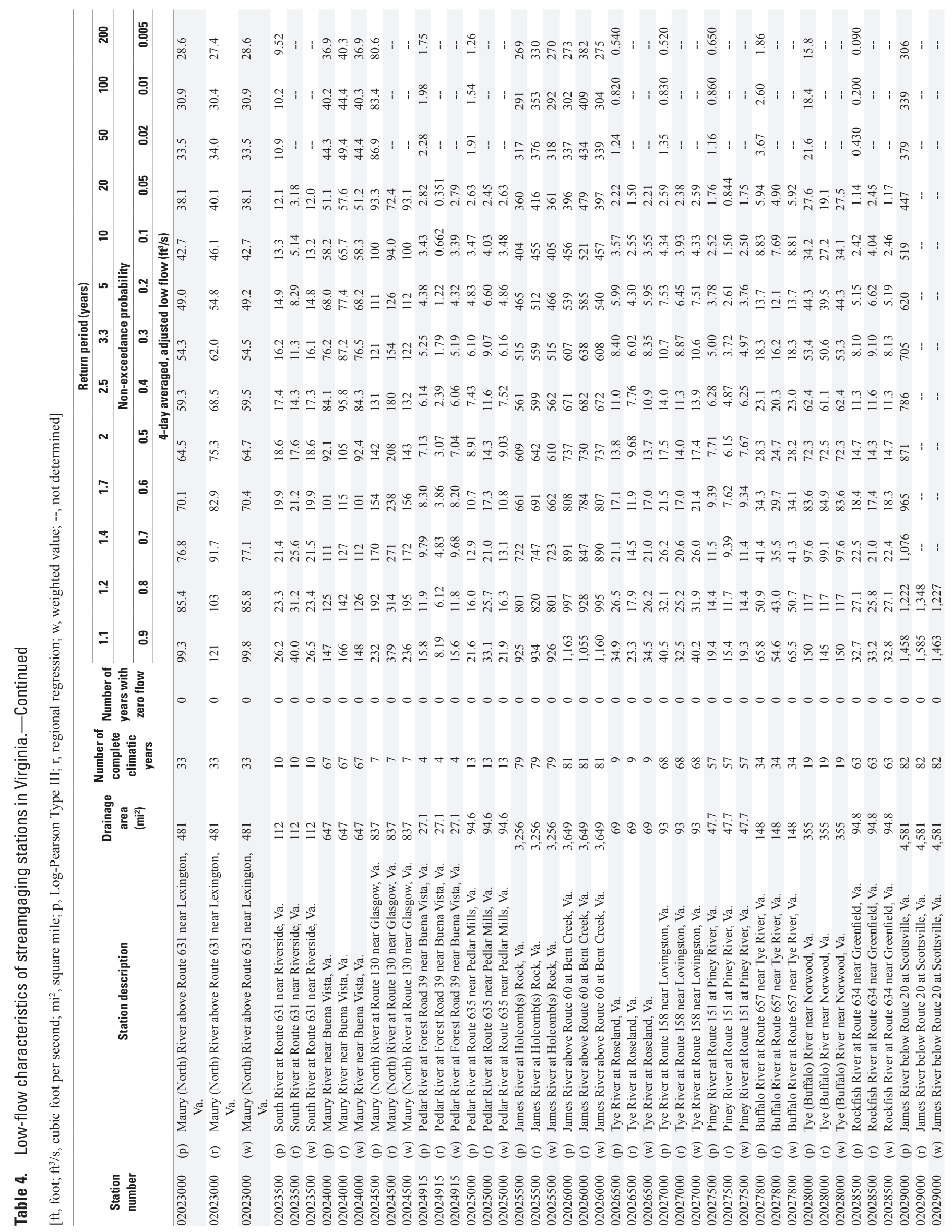




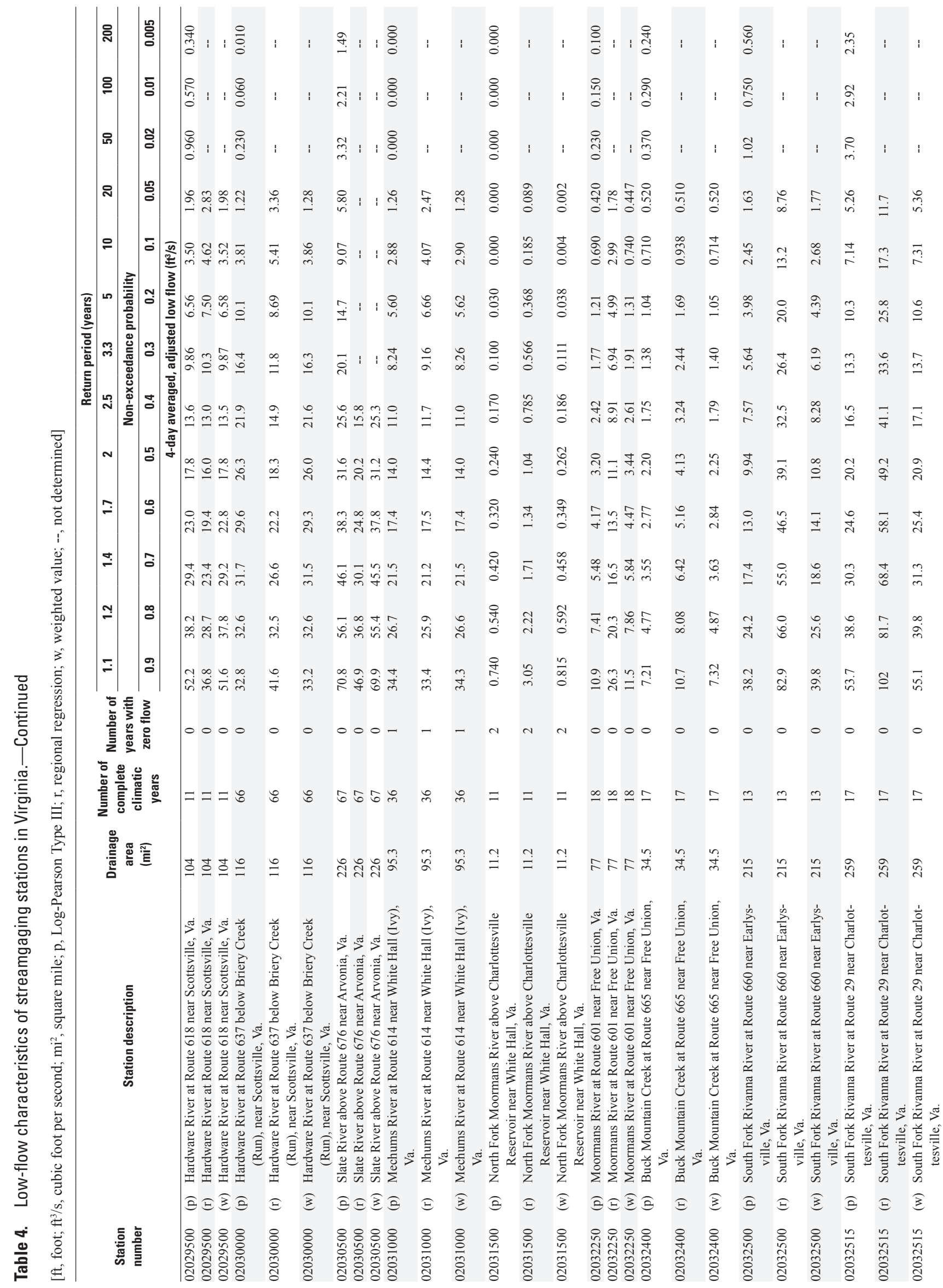




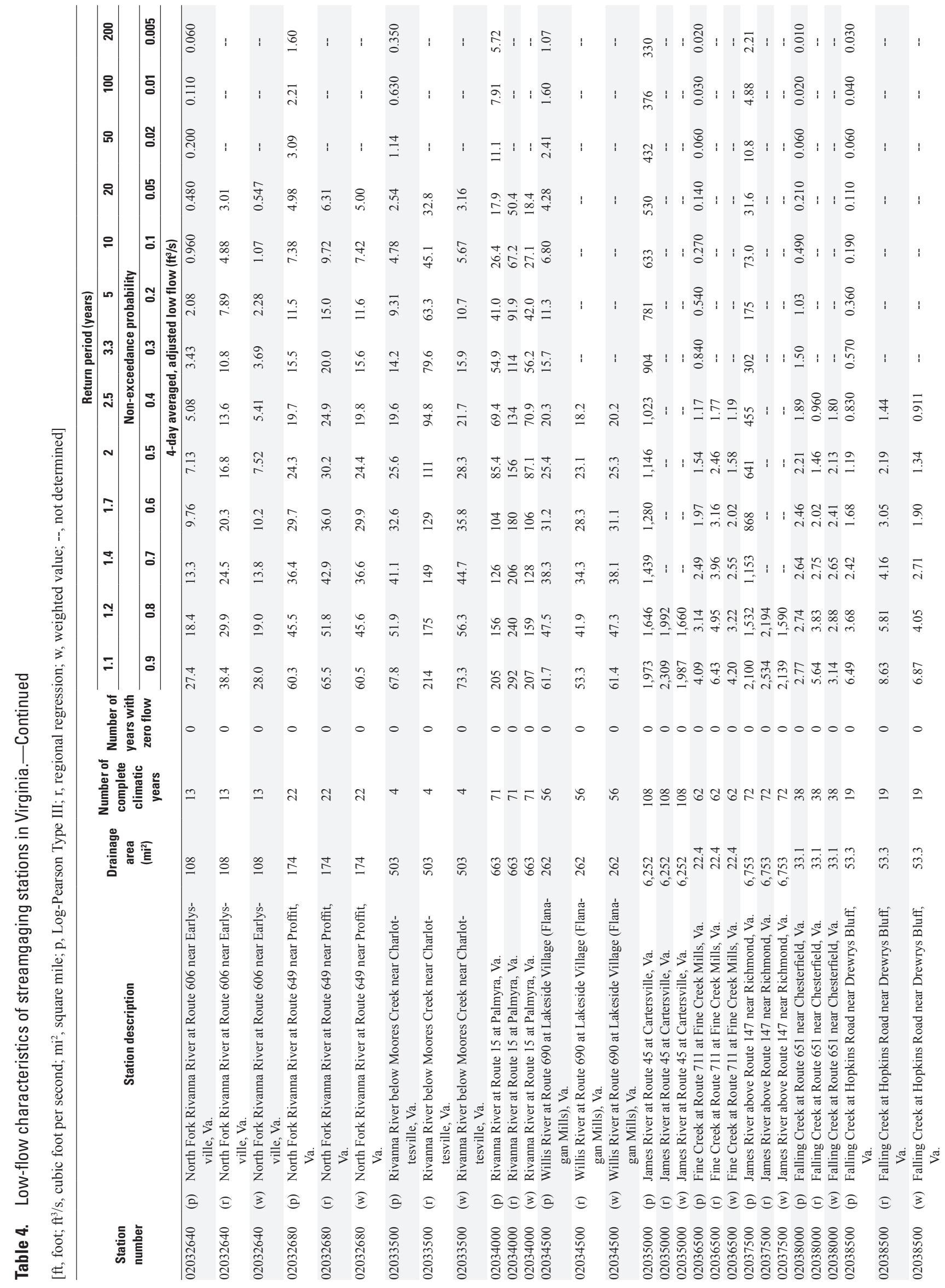




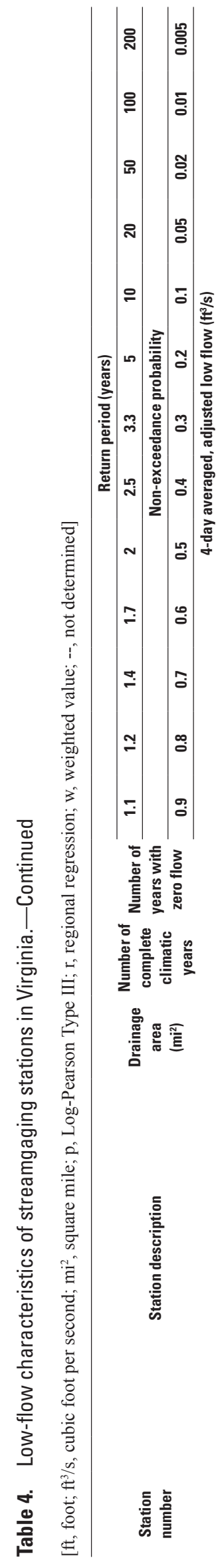

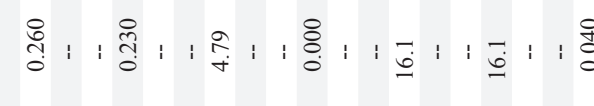

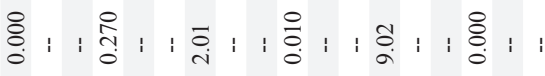

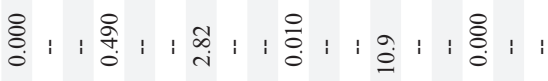

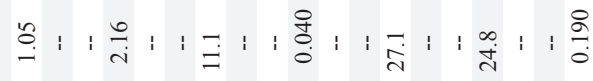

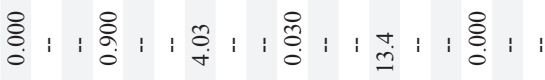

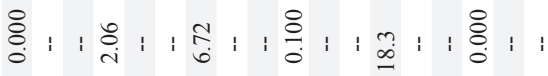

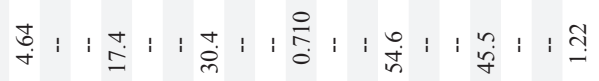

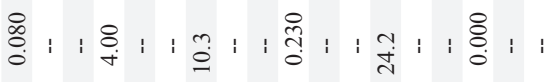

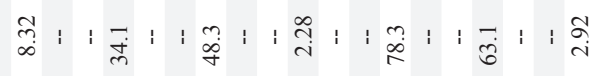

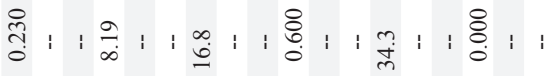

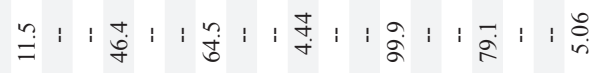

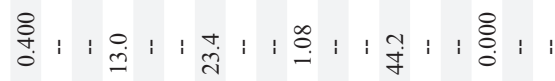

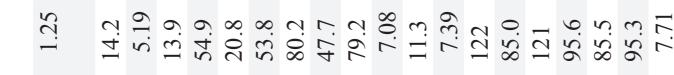

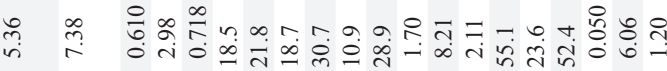

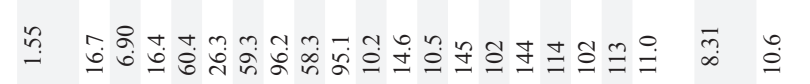

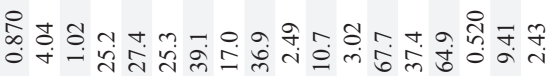

我

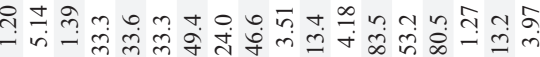

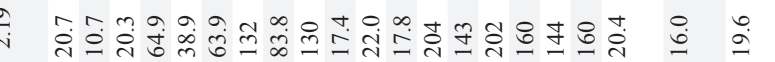

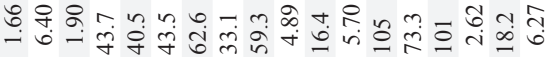

$\frac{1}{i}$

每

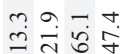

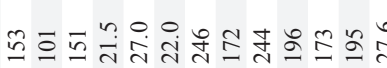

สุ่

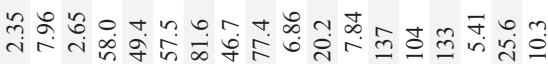

$\stackrel{\substack{\infty \\ i}}{\circ}$

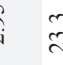

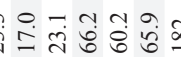

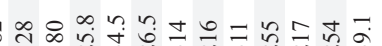

$\underset{\infty}{\infty}$

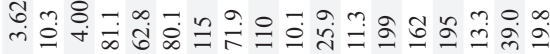

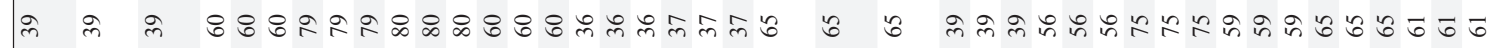

每

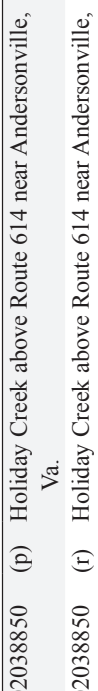

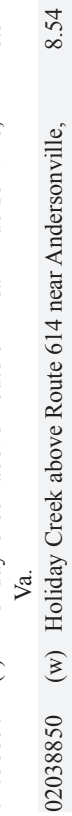

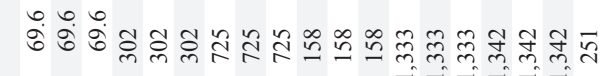
我这

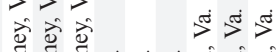

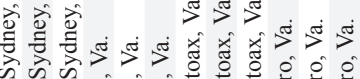

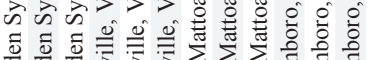

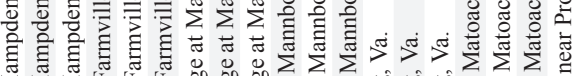

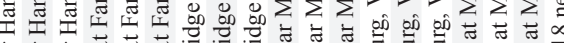

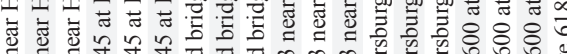

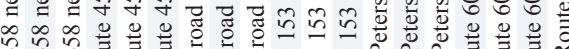

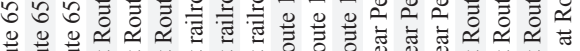

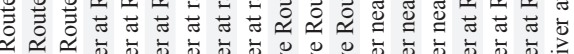

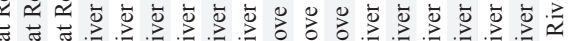

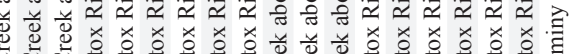

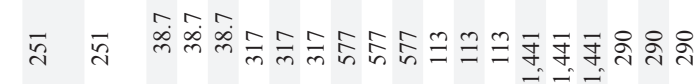

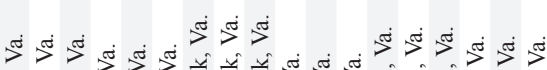

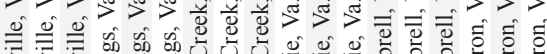

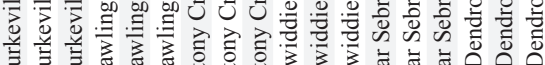

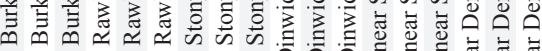

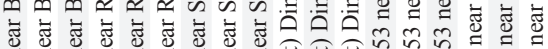

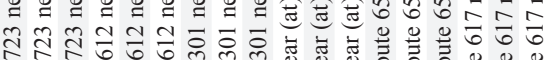

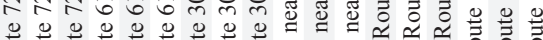

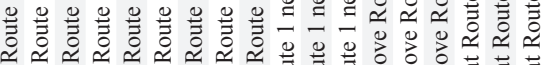

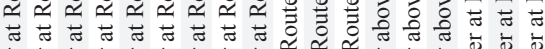

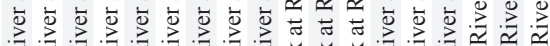

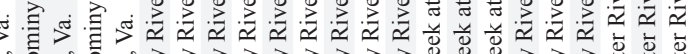

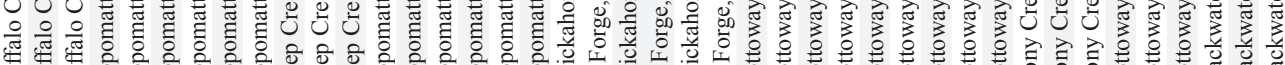

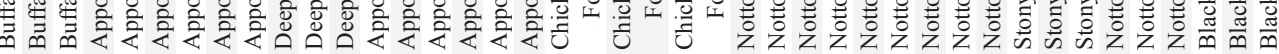

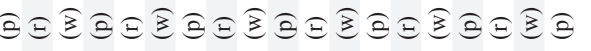




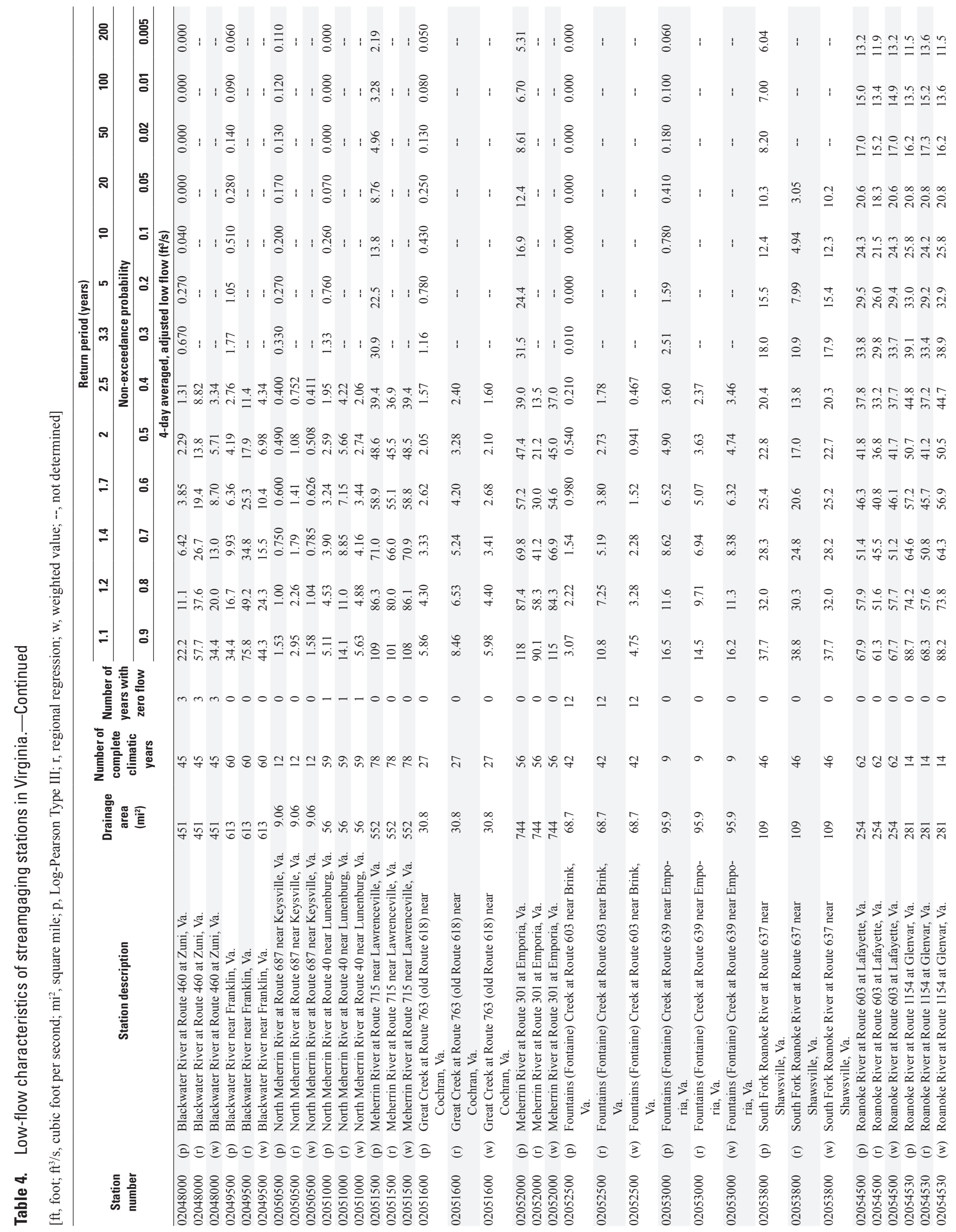




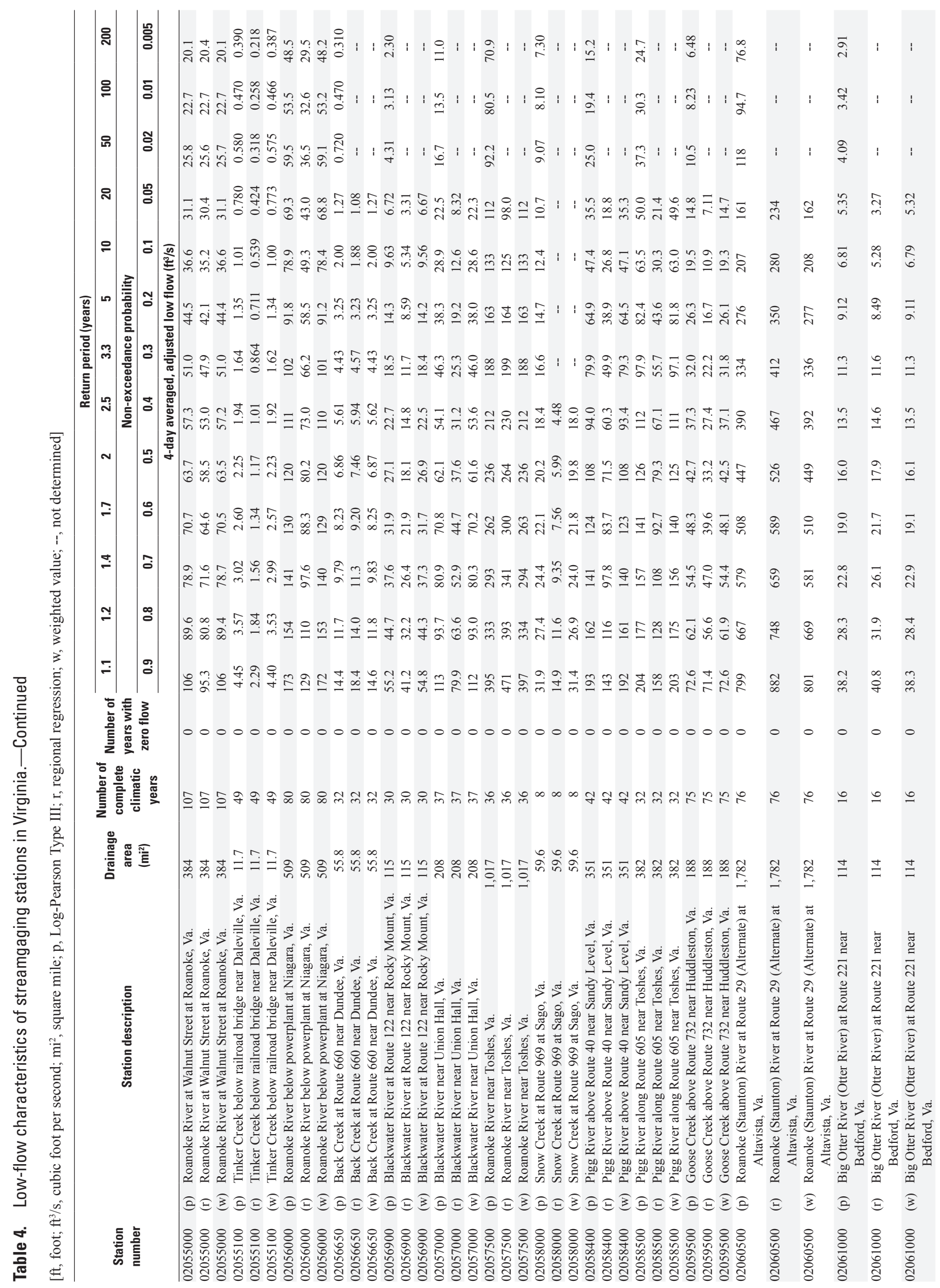




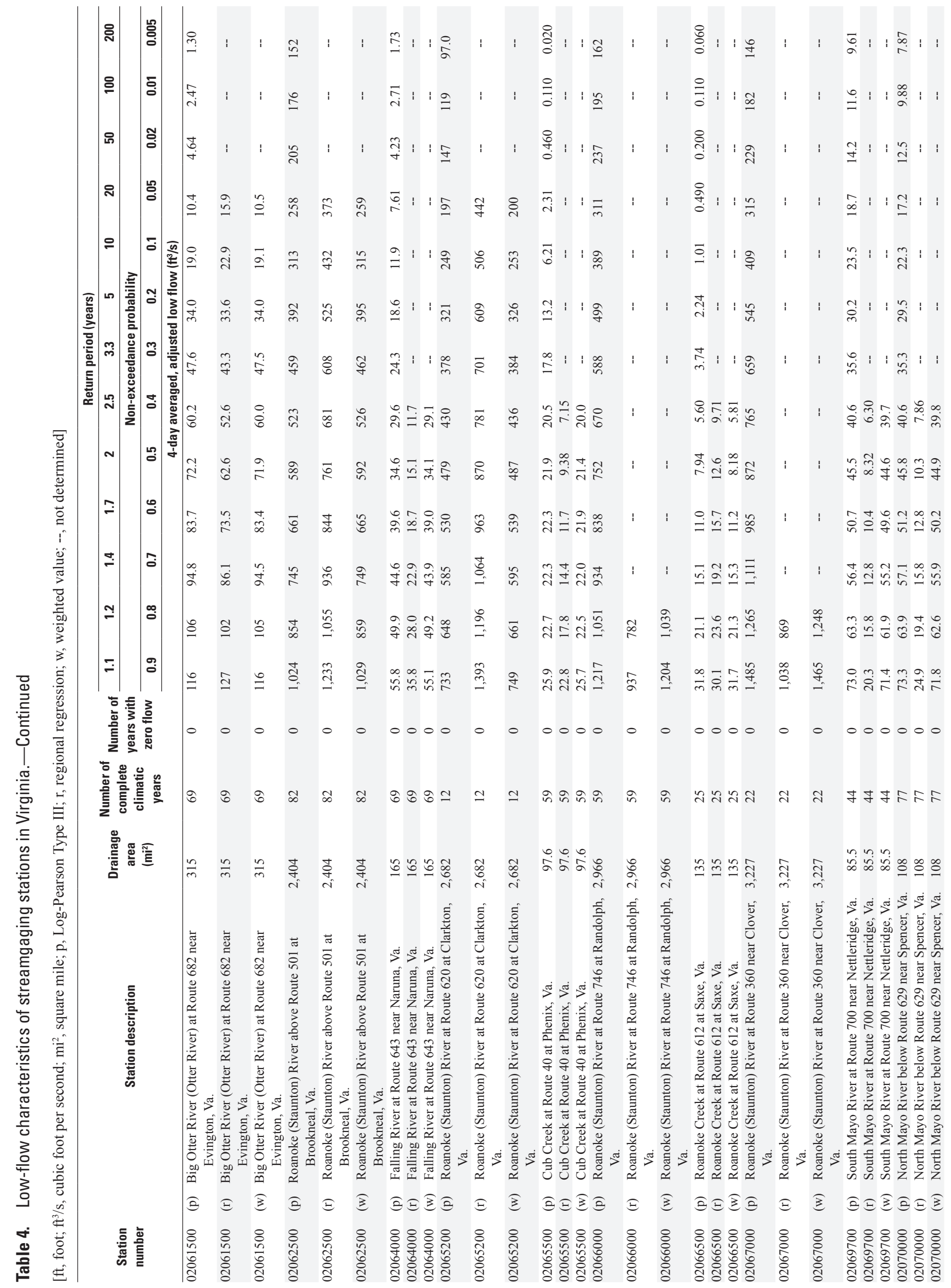




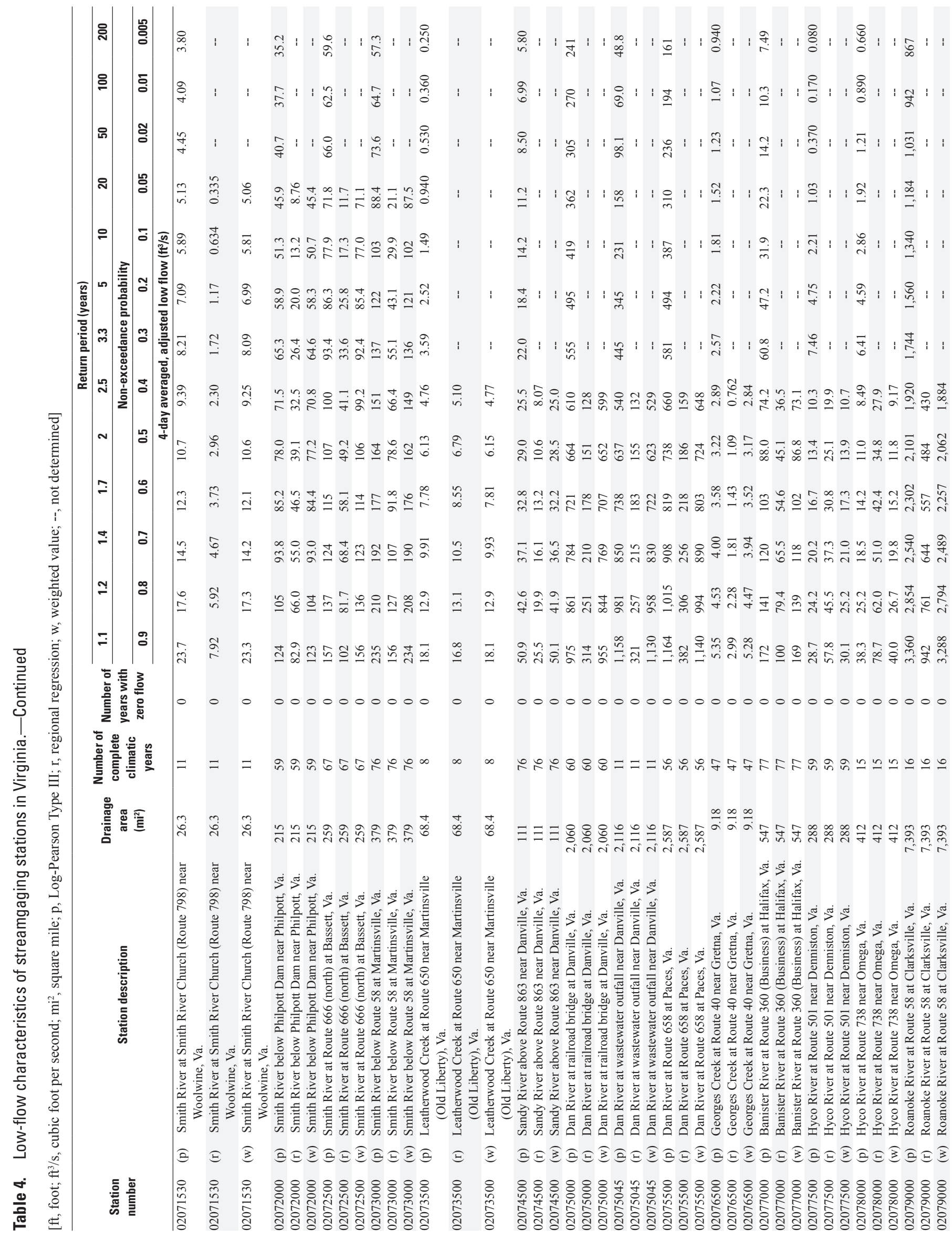




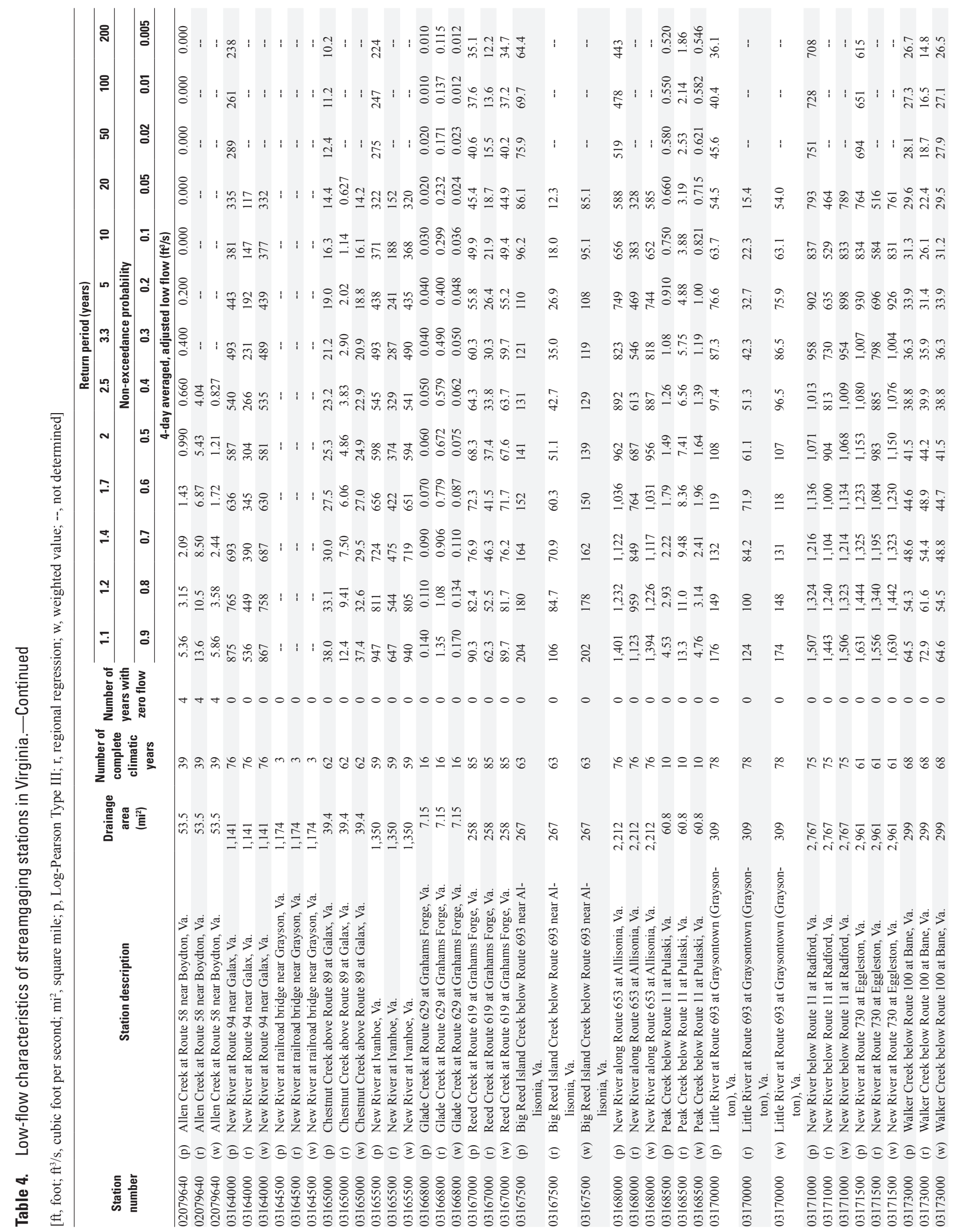




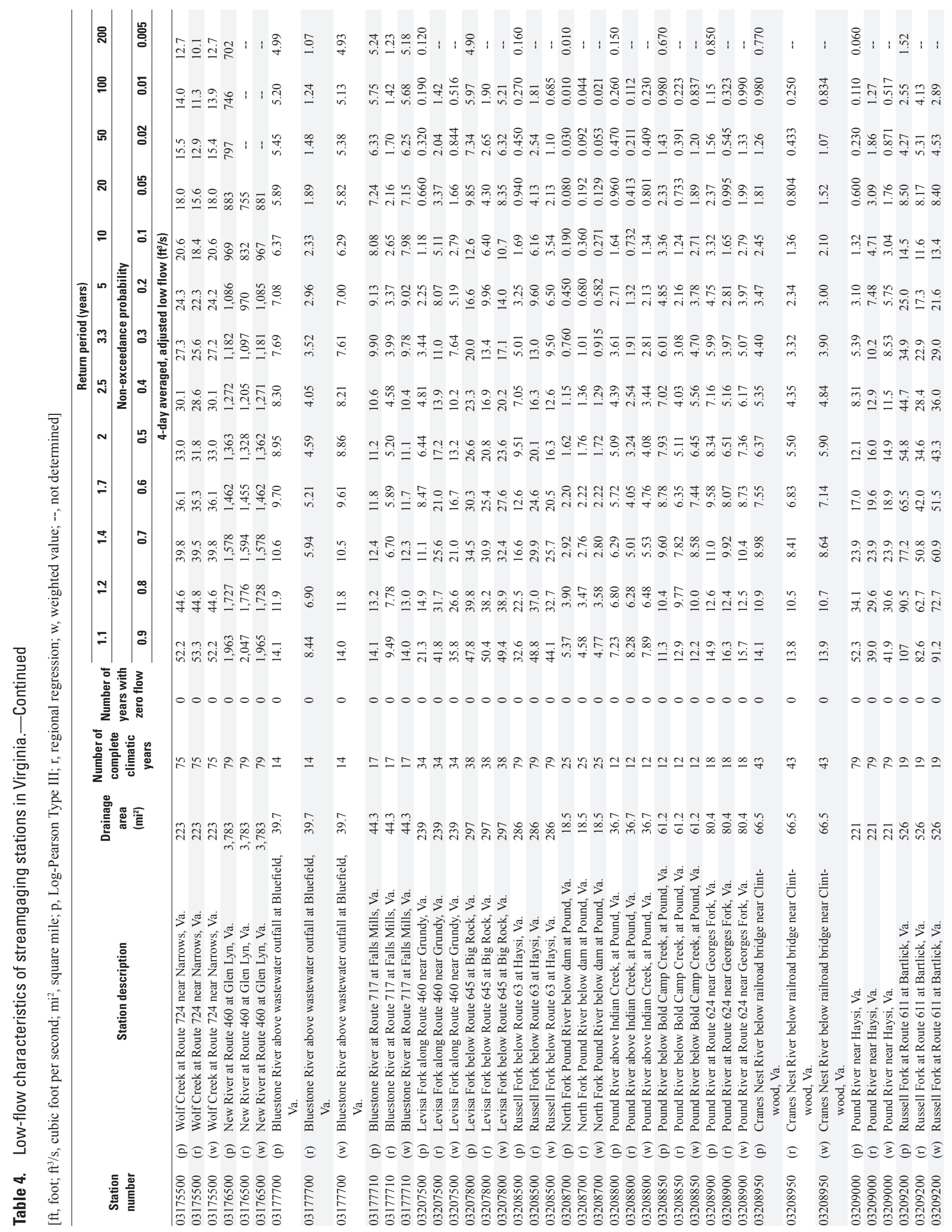




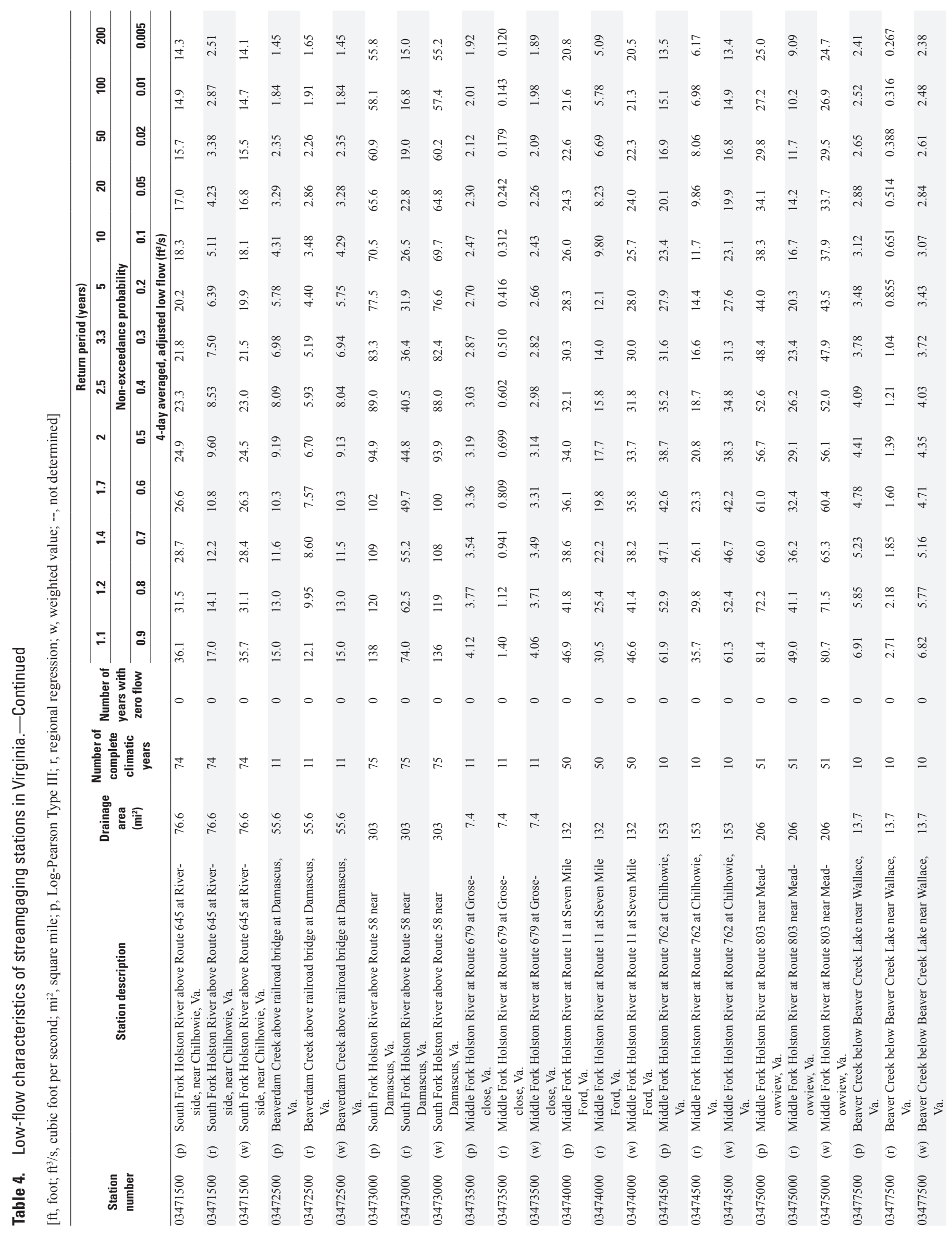




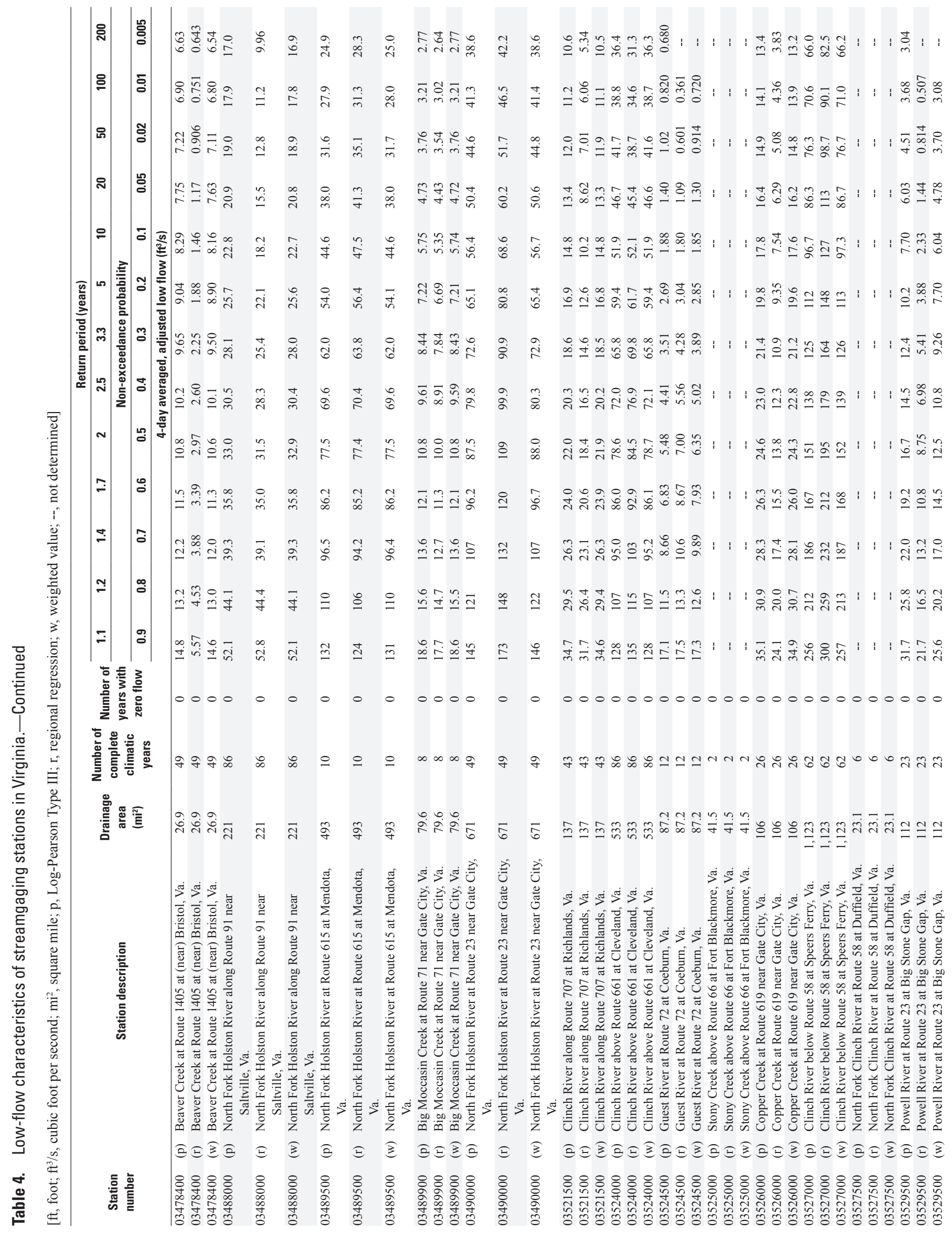




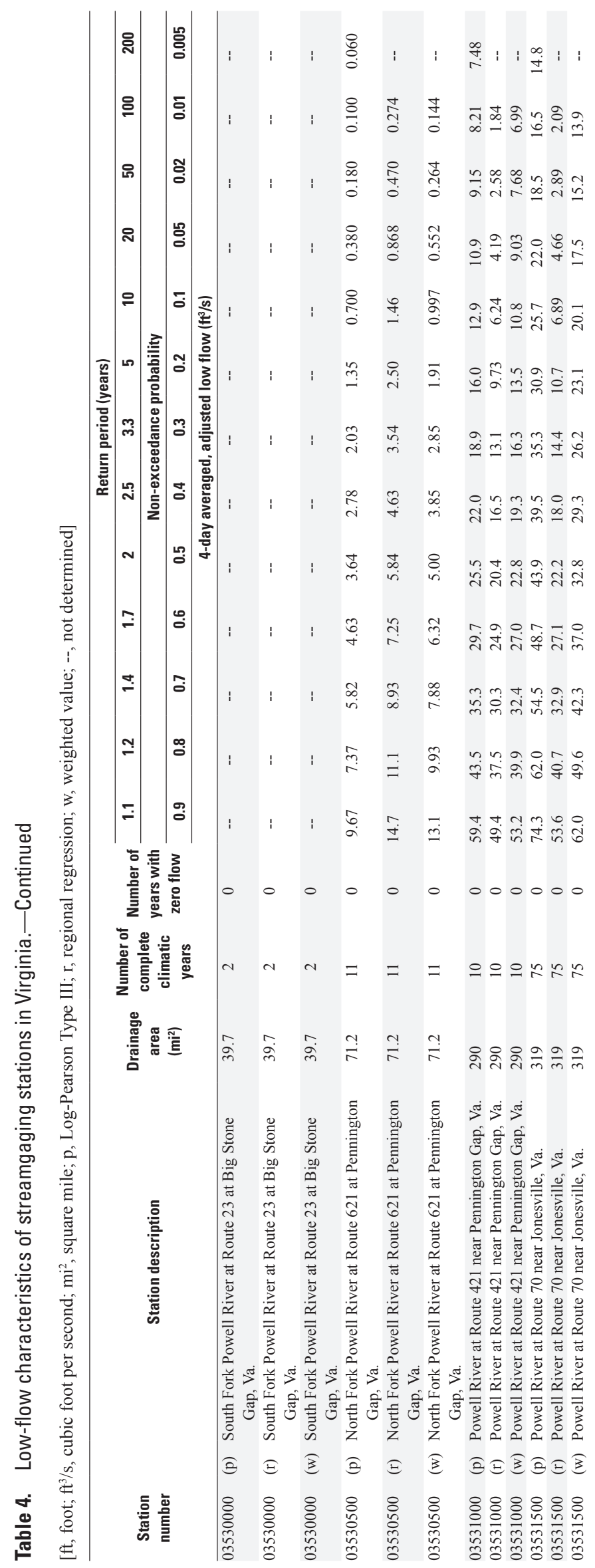




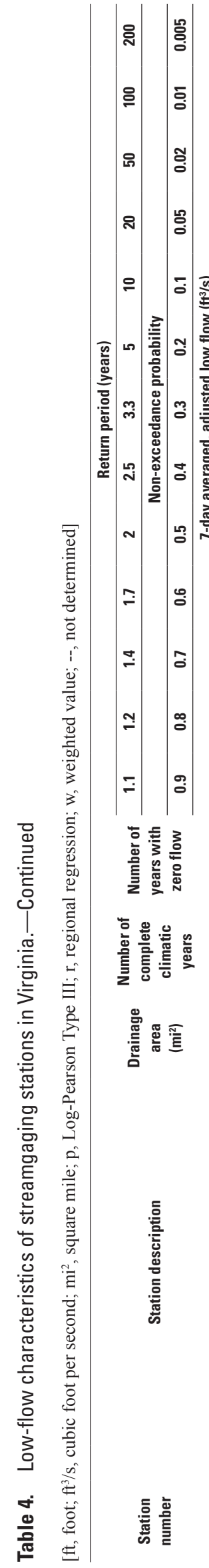

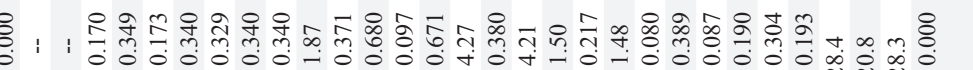

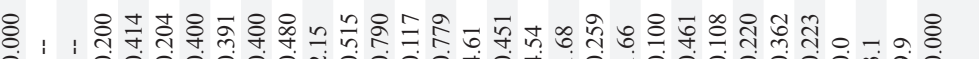

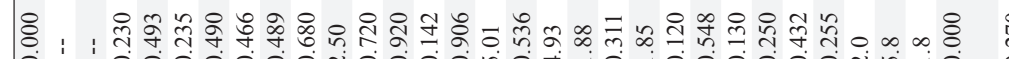

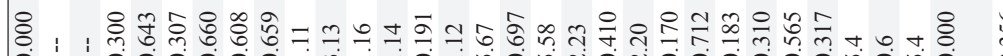

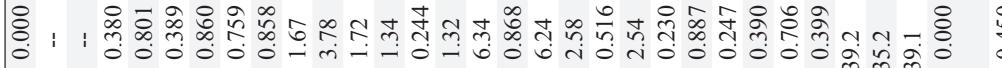

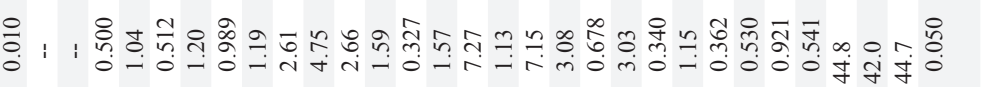

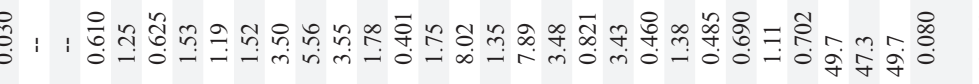

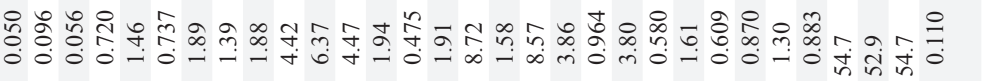

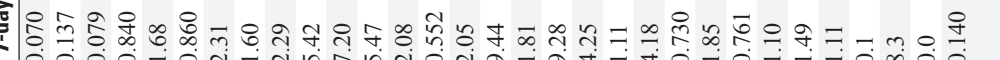

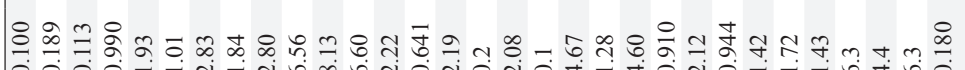

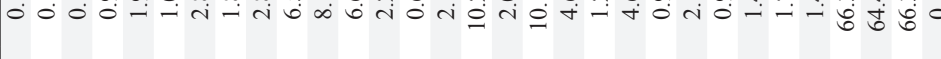

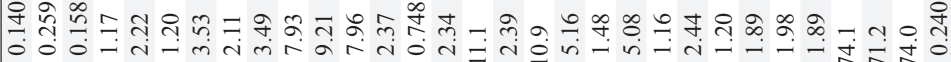

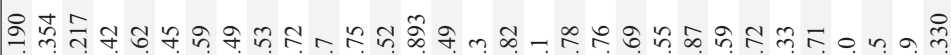

(0)

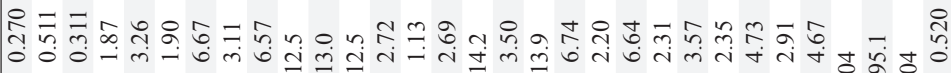
(5)

$4 t+000000000000000000000000000-$

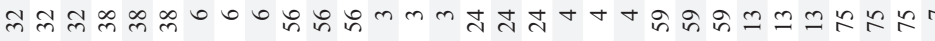

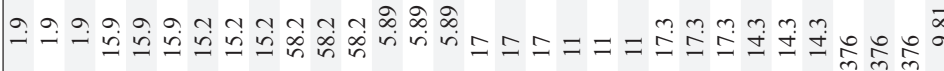

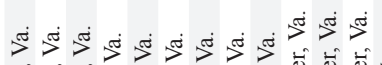

$\sum_{\substack{\infty \\ \infty}}^{\infty}$

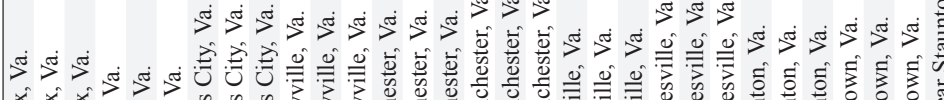

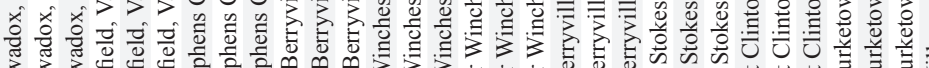

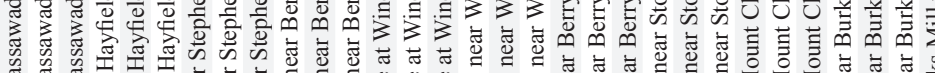

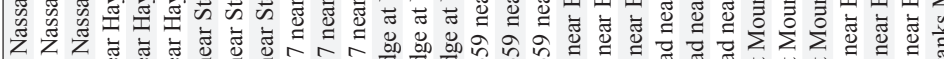

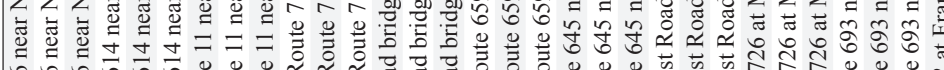

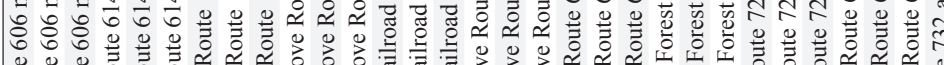

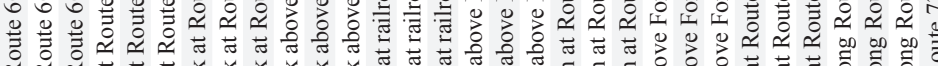

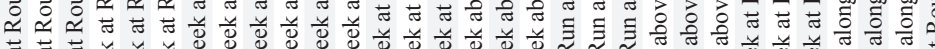

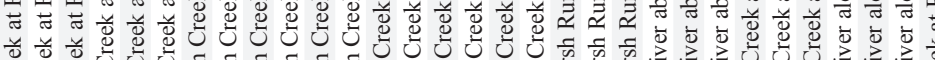

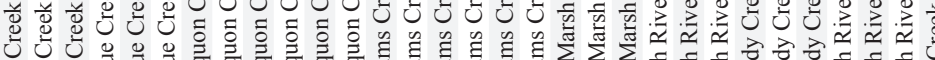

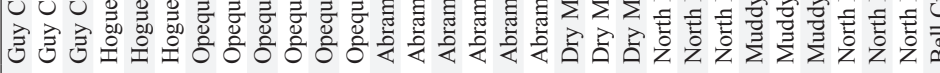

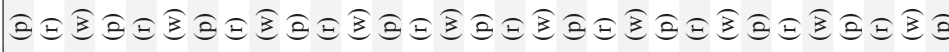

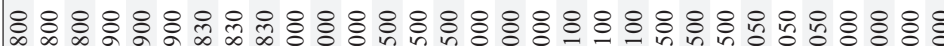

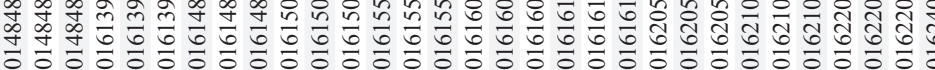

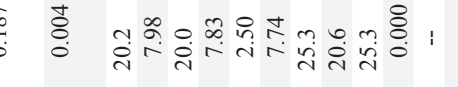

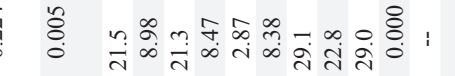

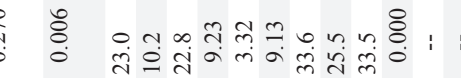

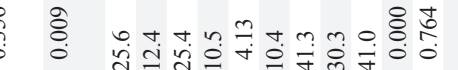

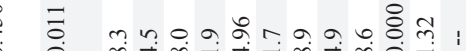

ఫั

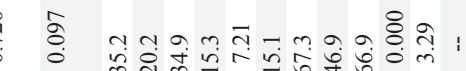

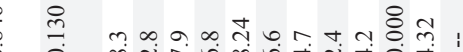
管

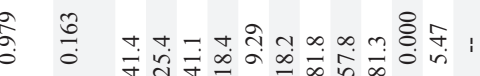

$=$ กั (1)

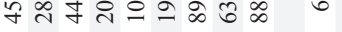

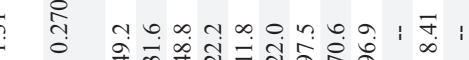

n 0
0

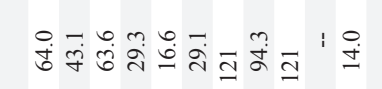




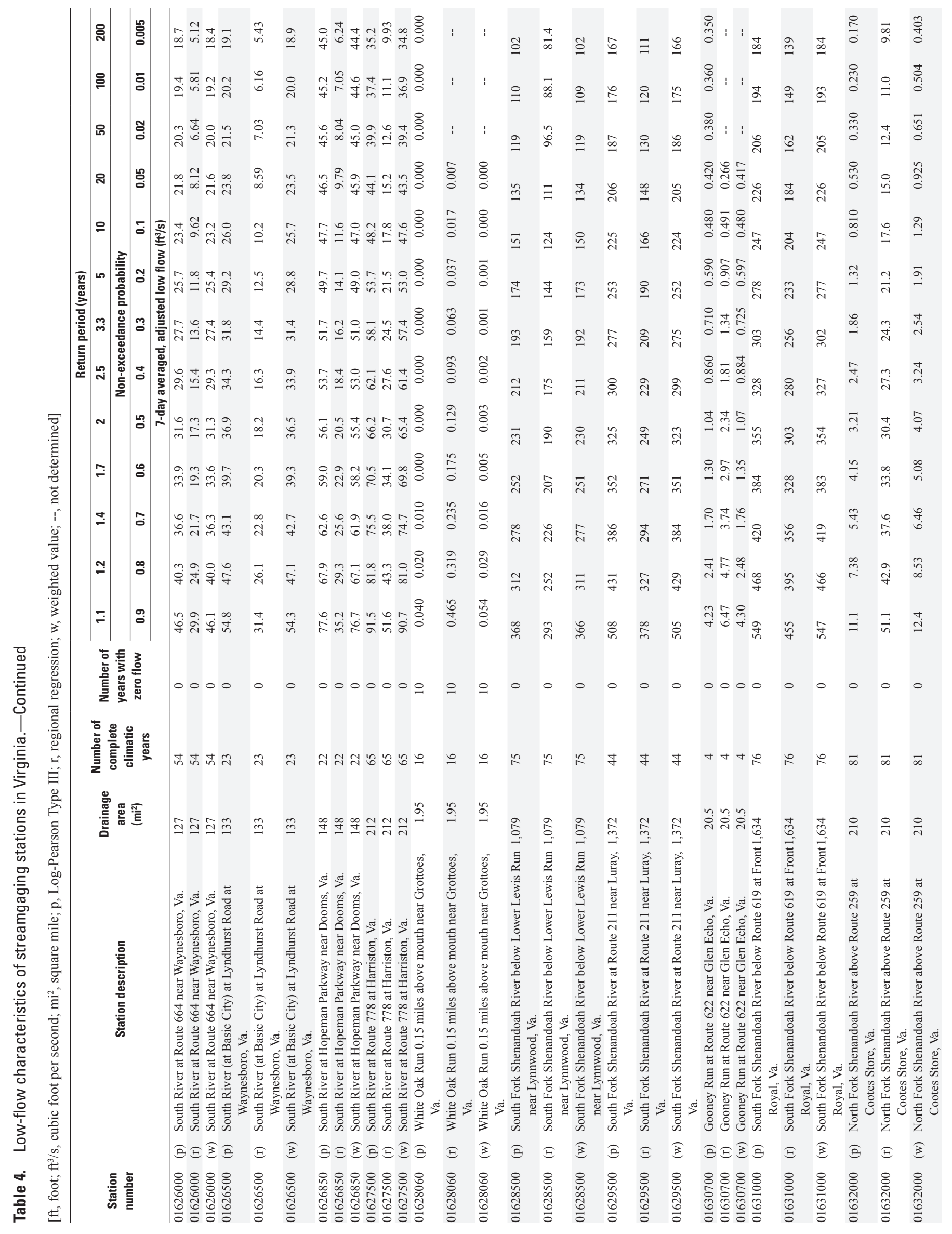




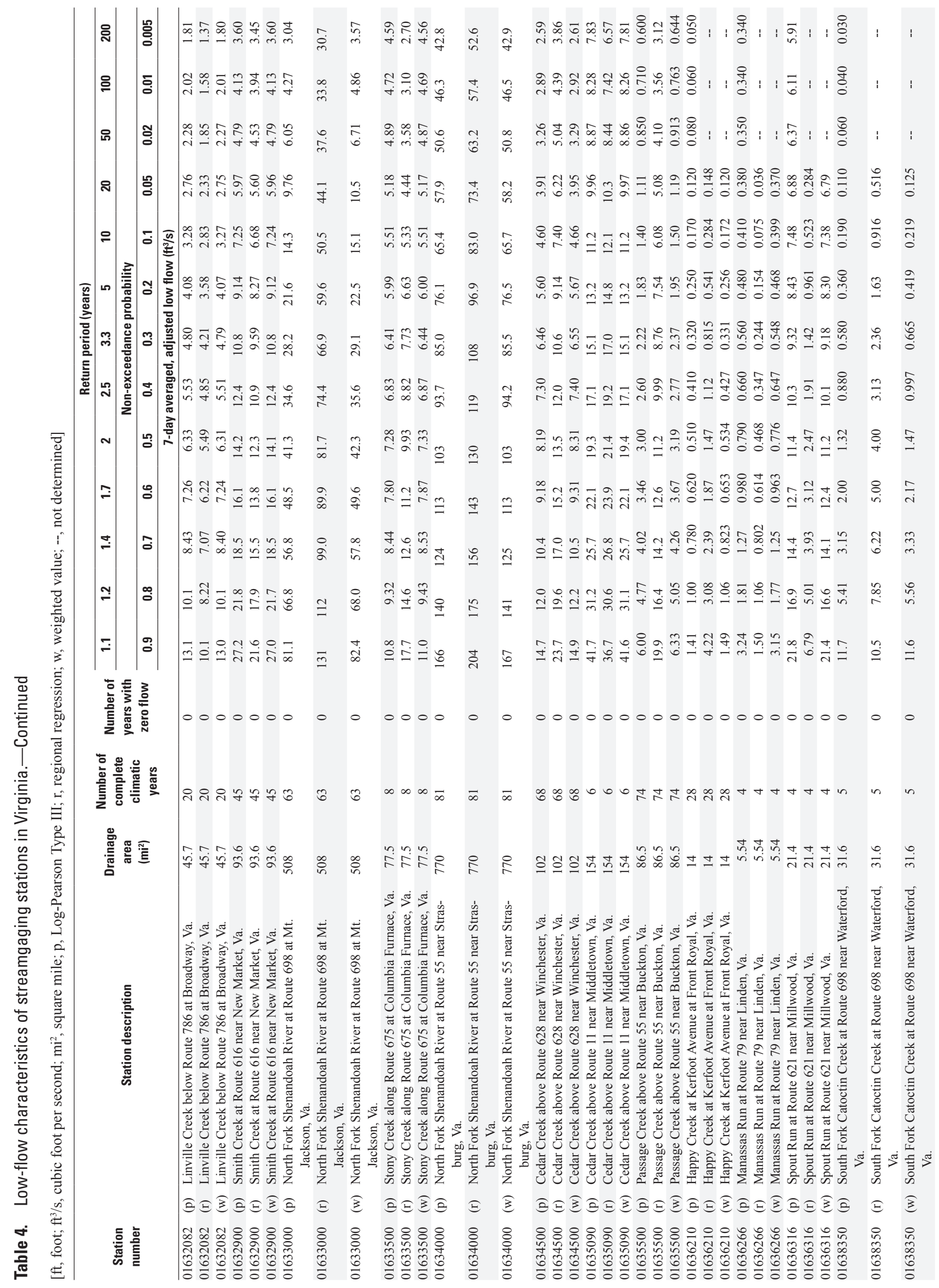




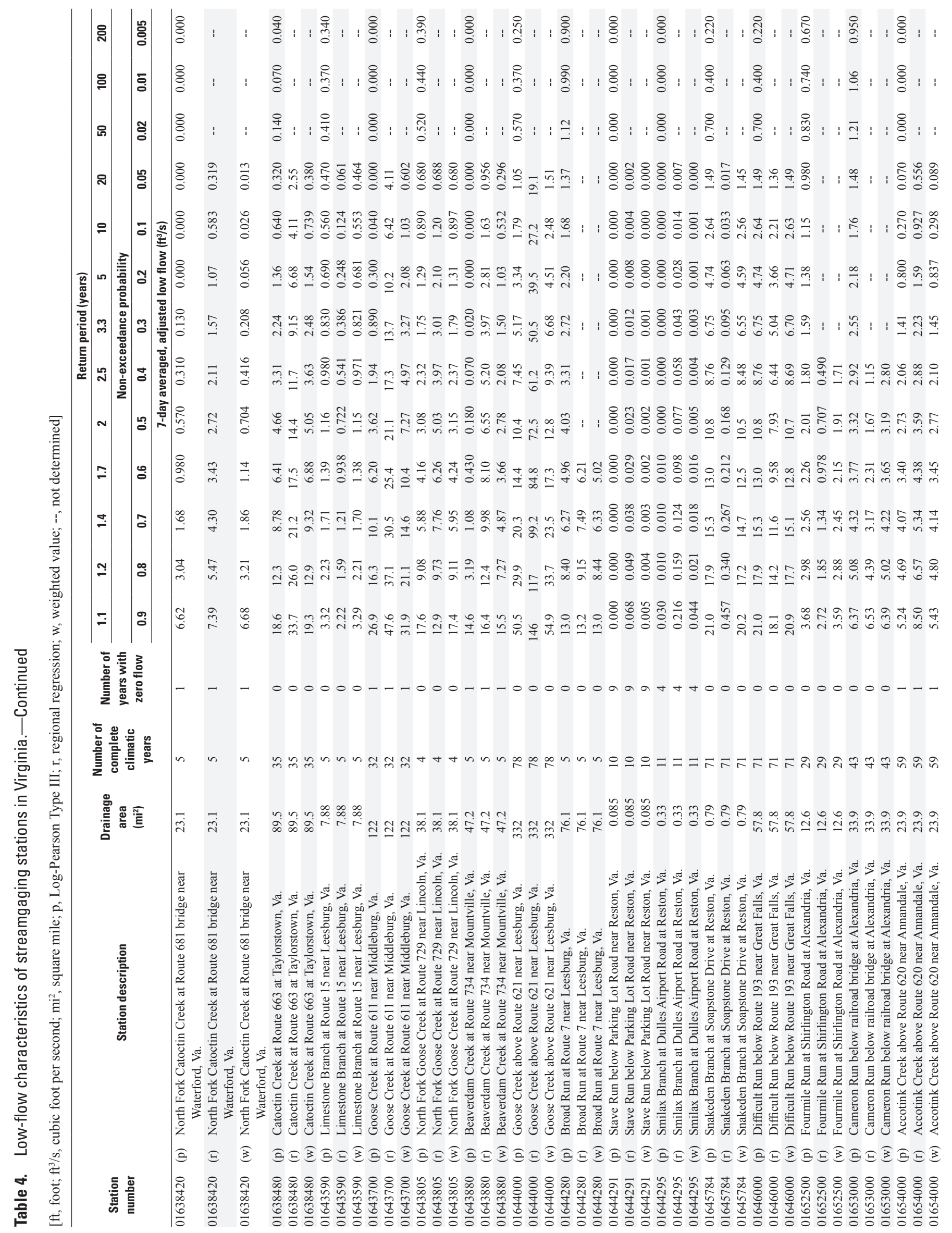




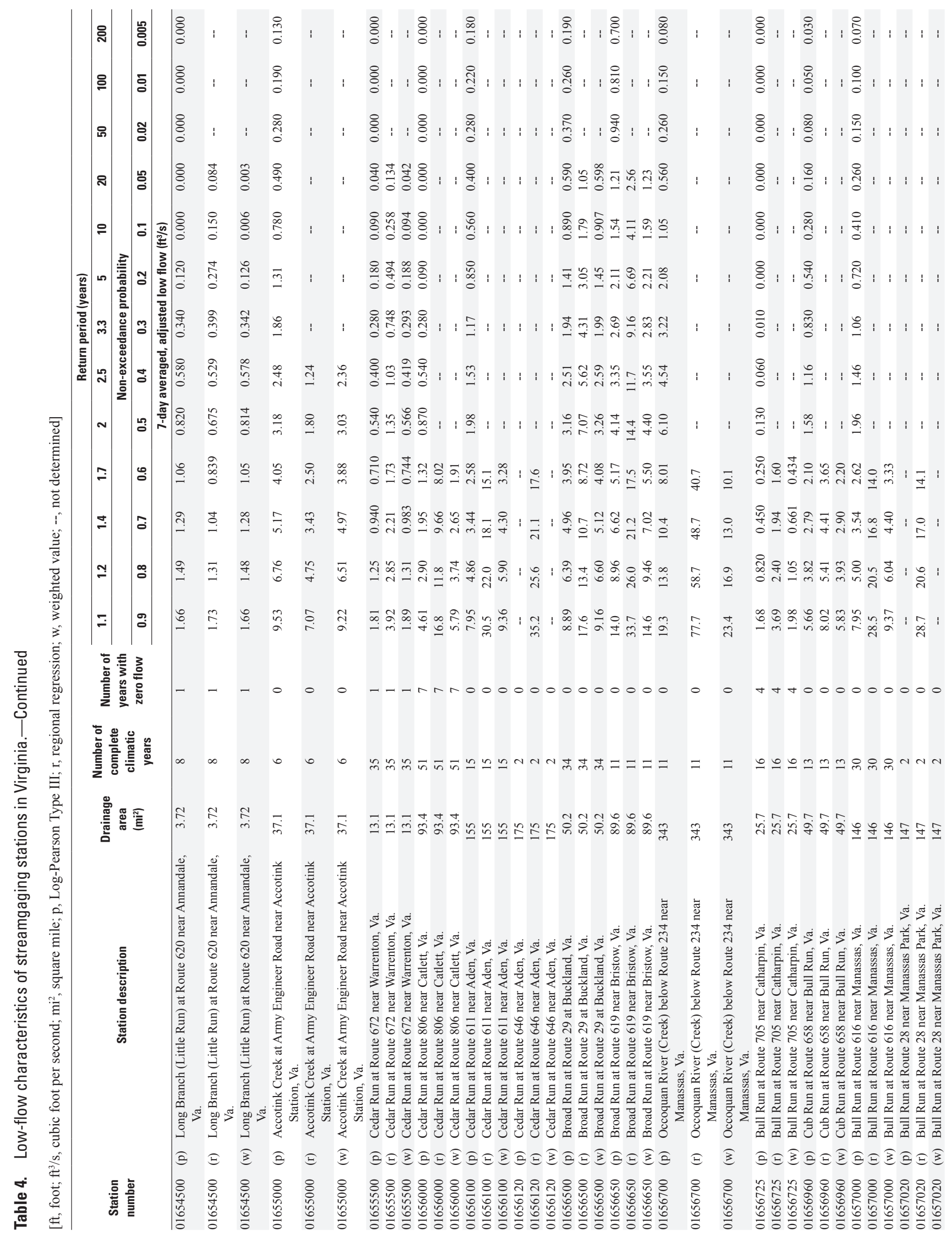




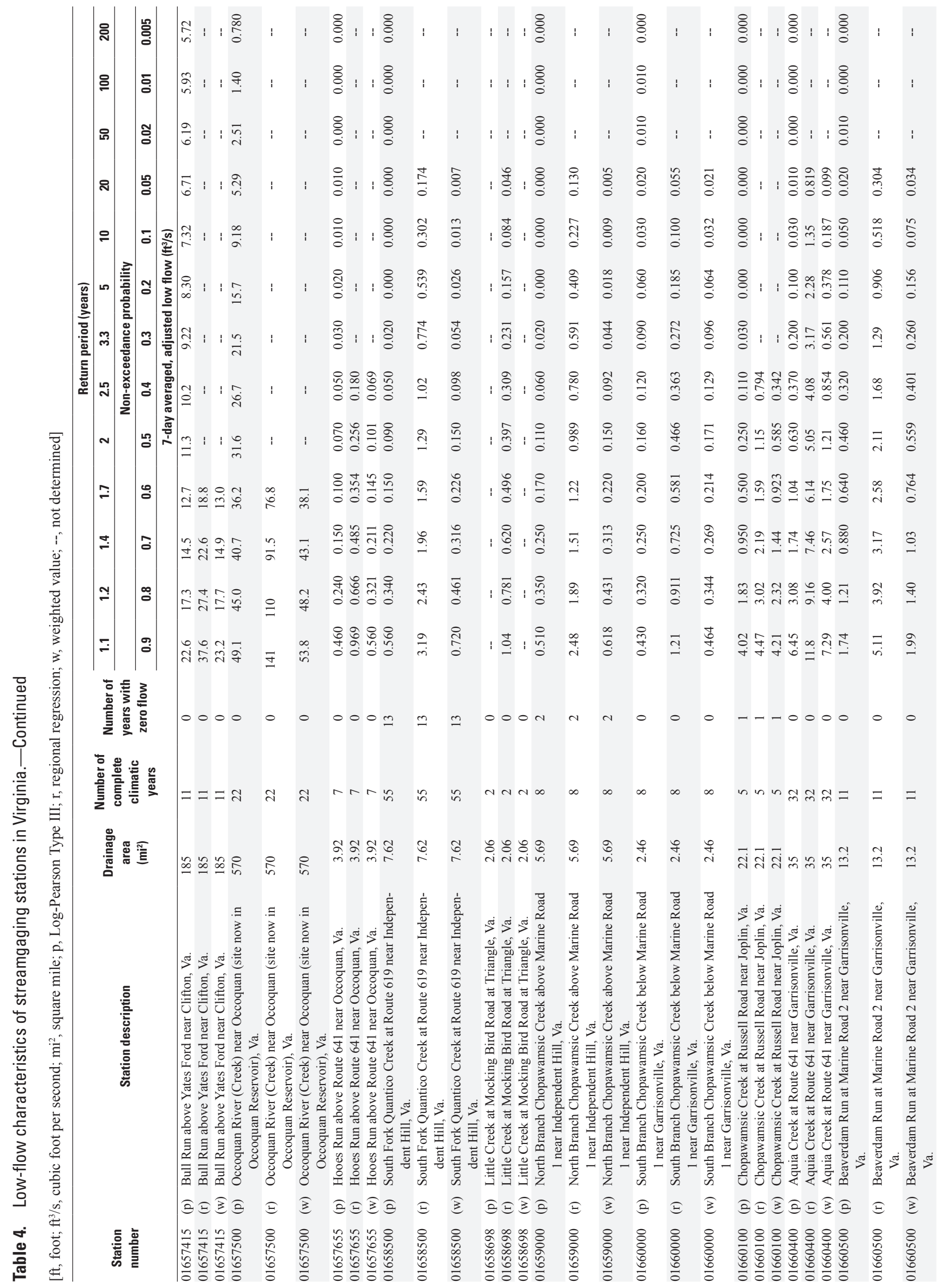




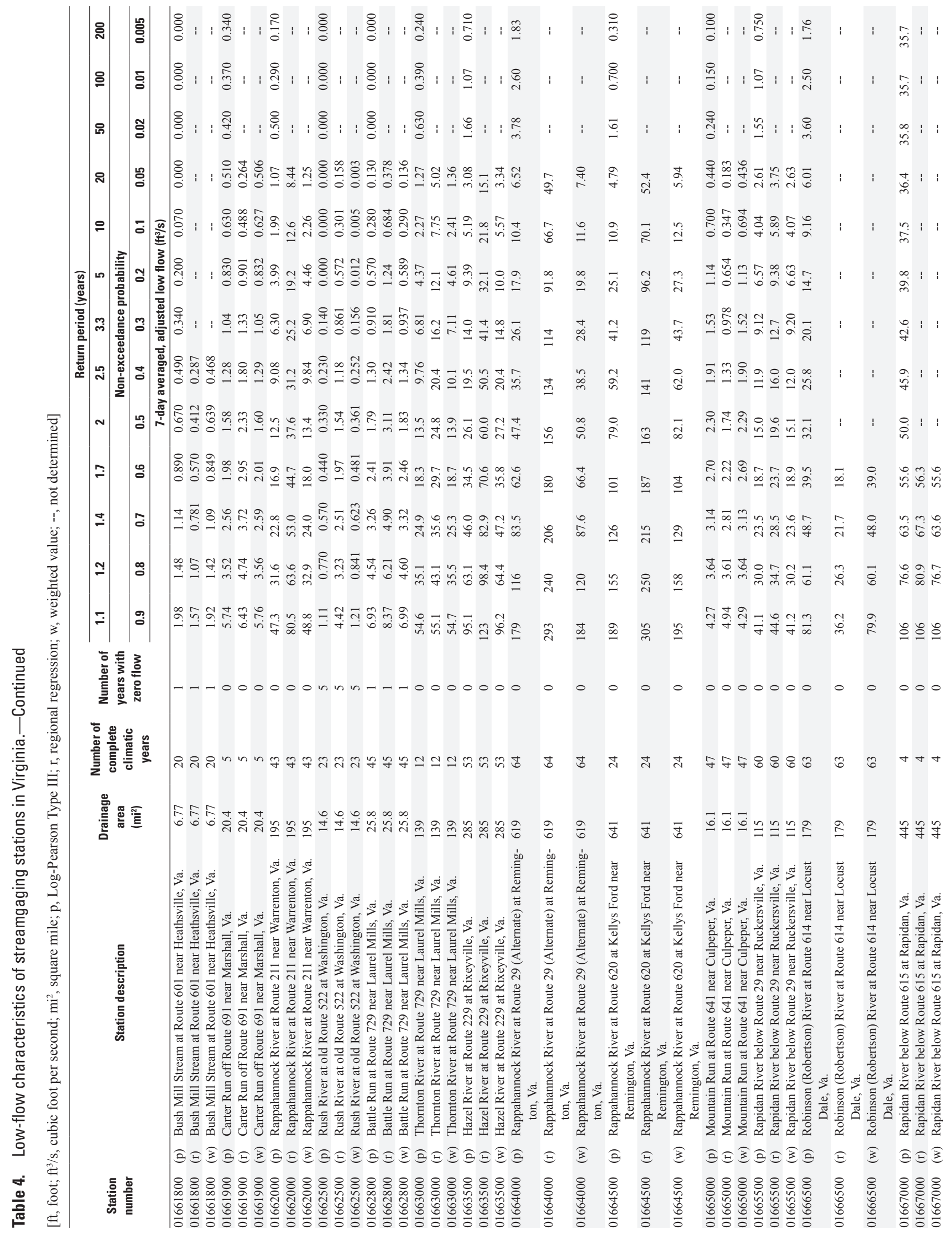




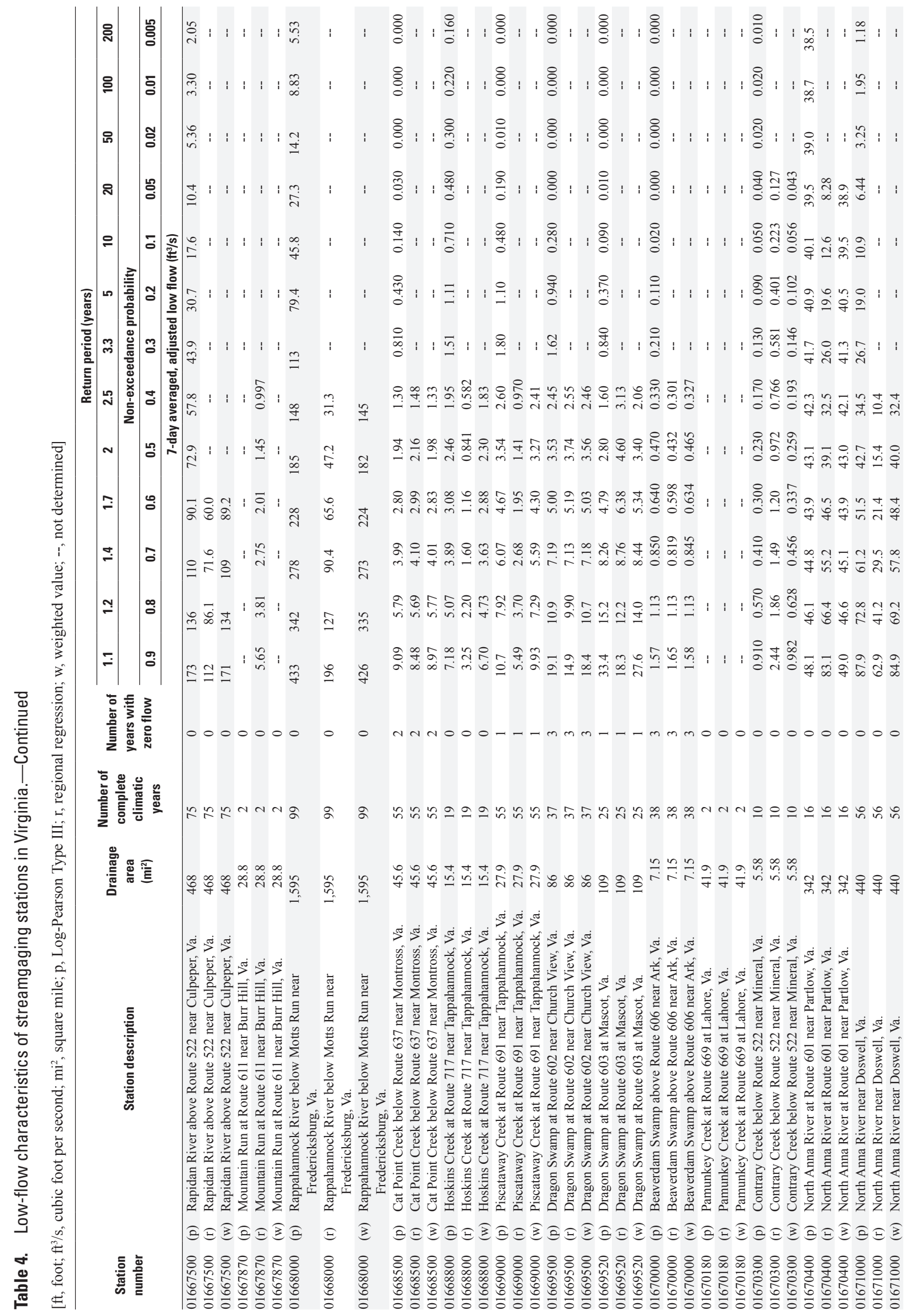




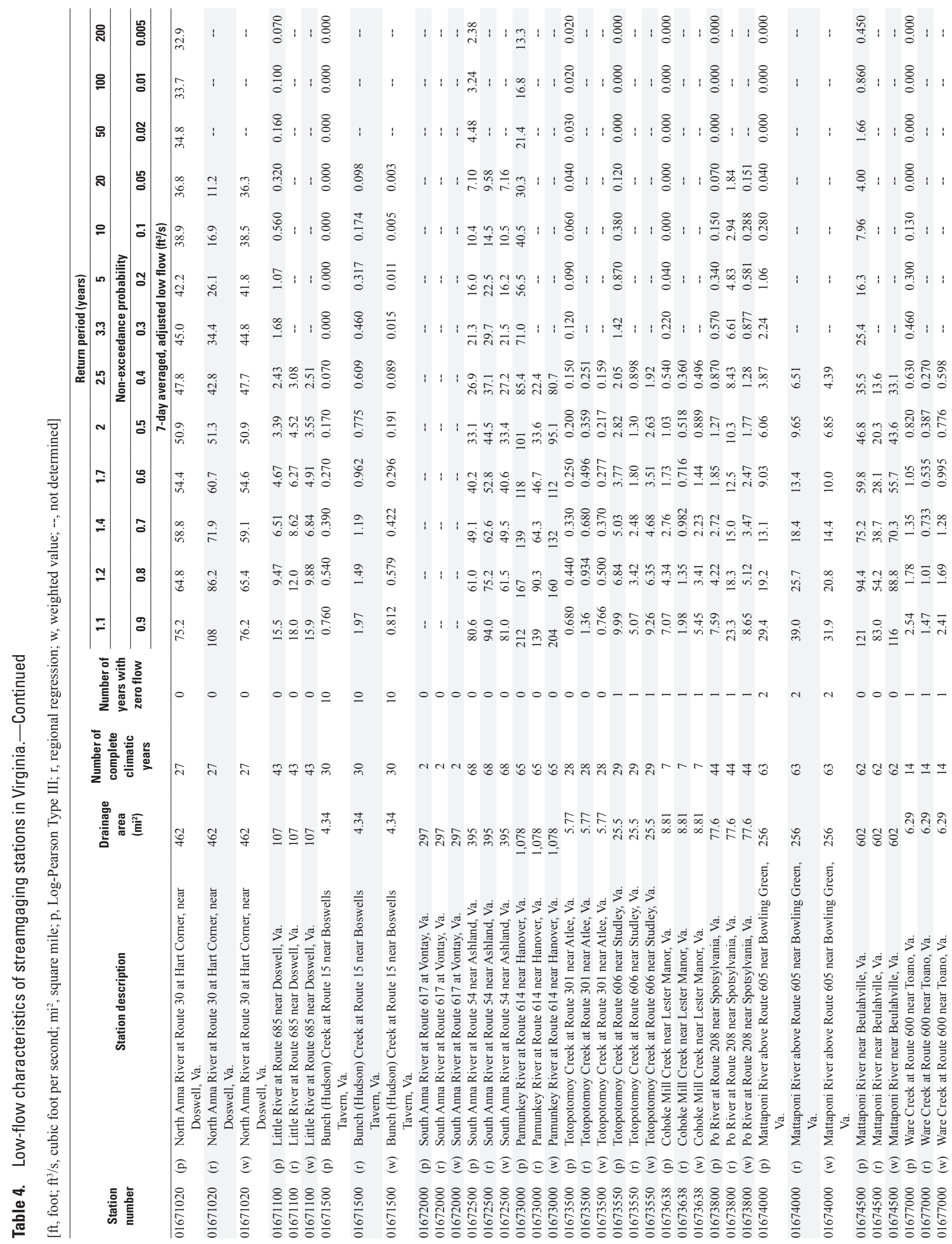




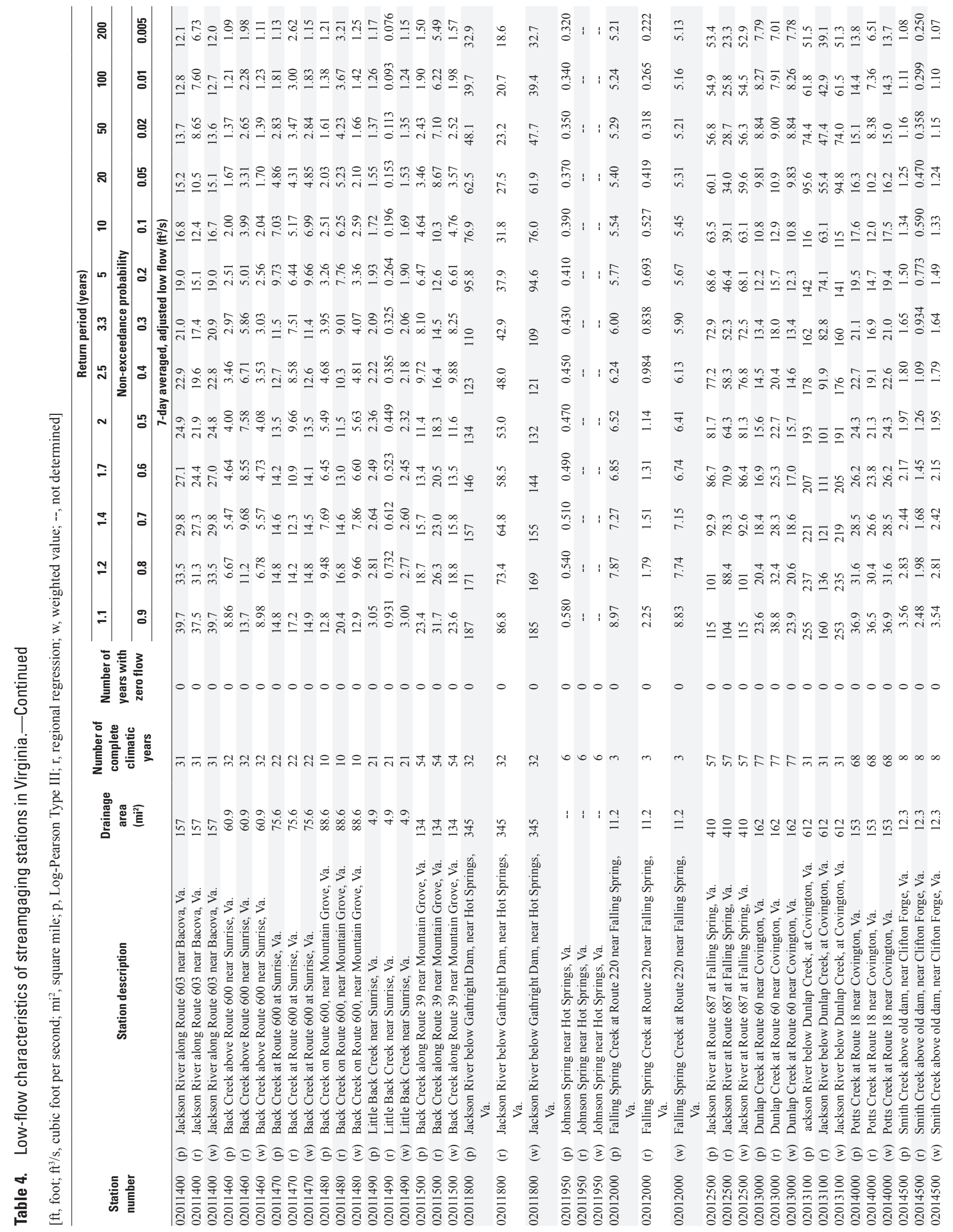




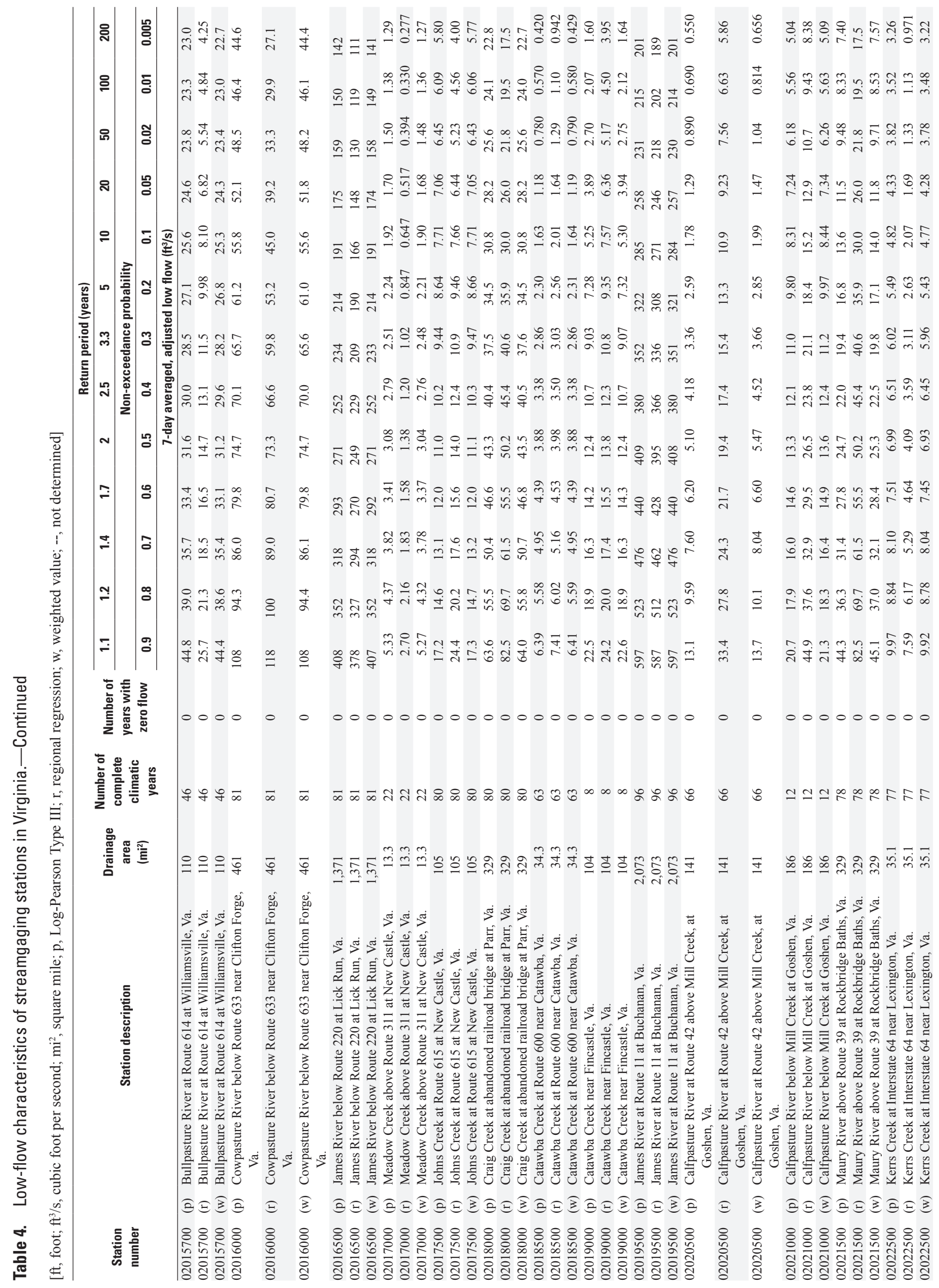




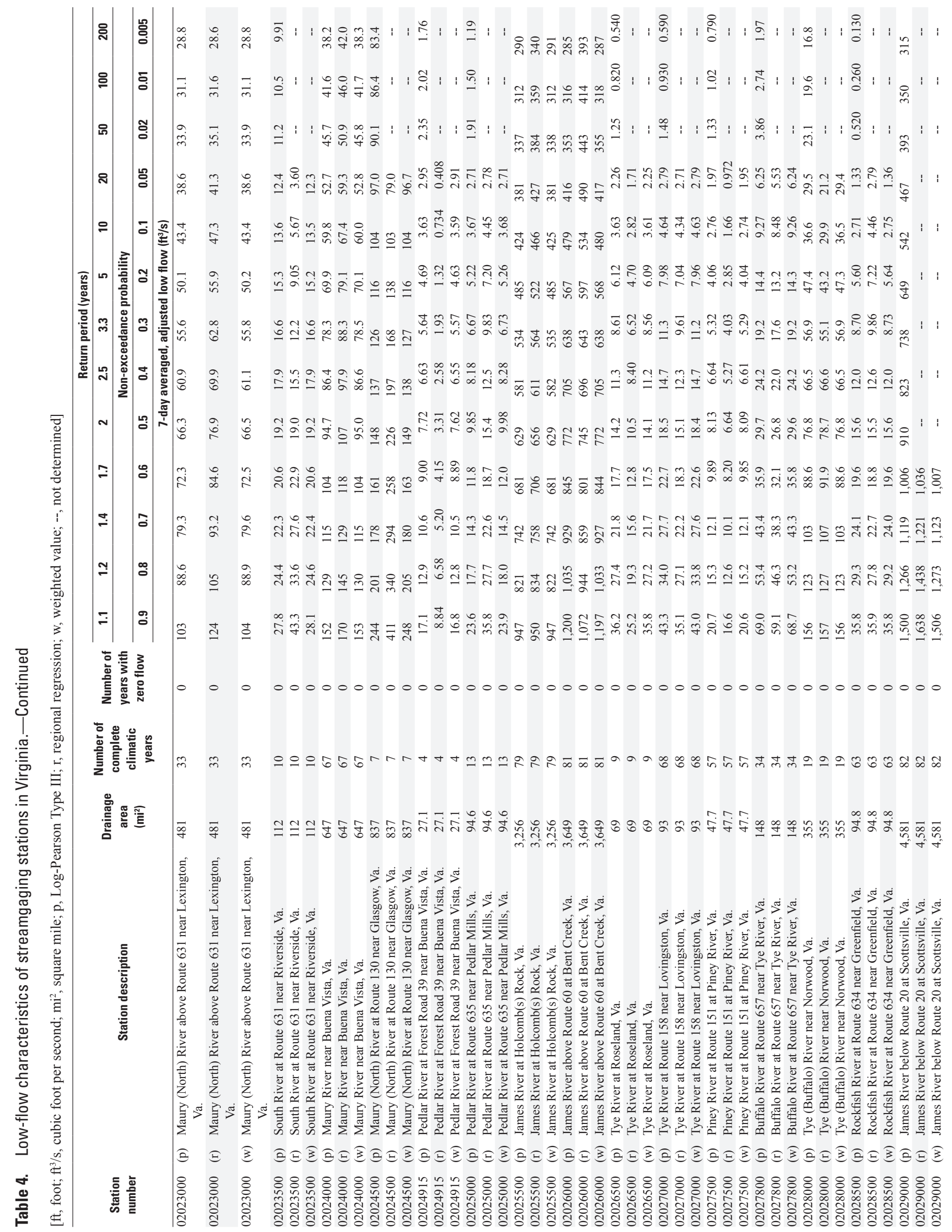




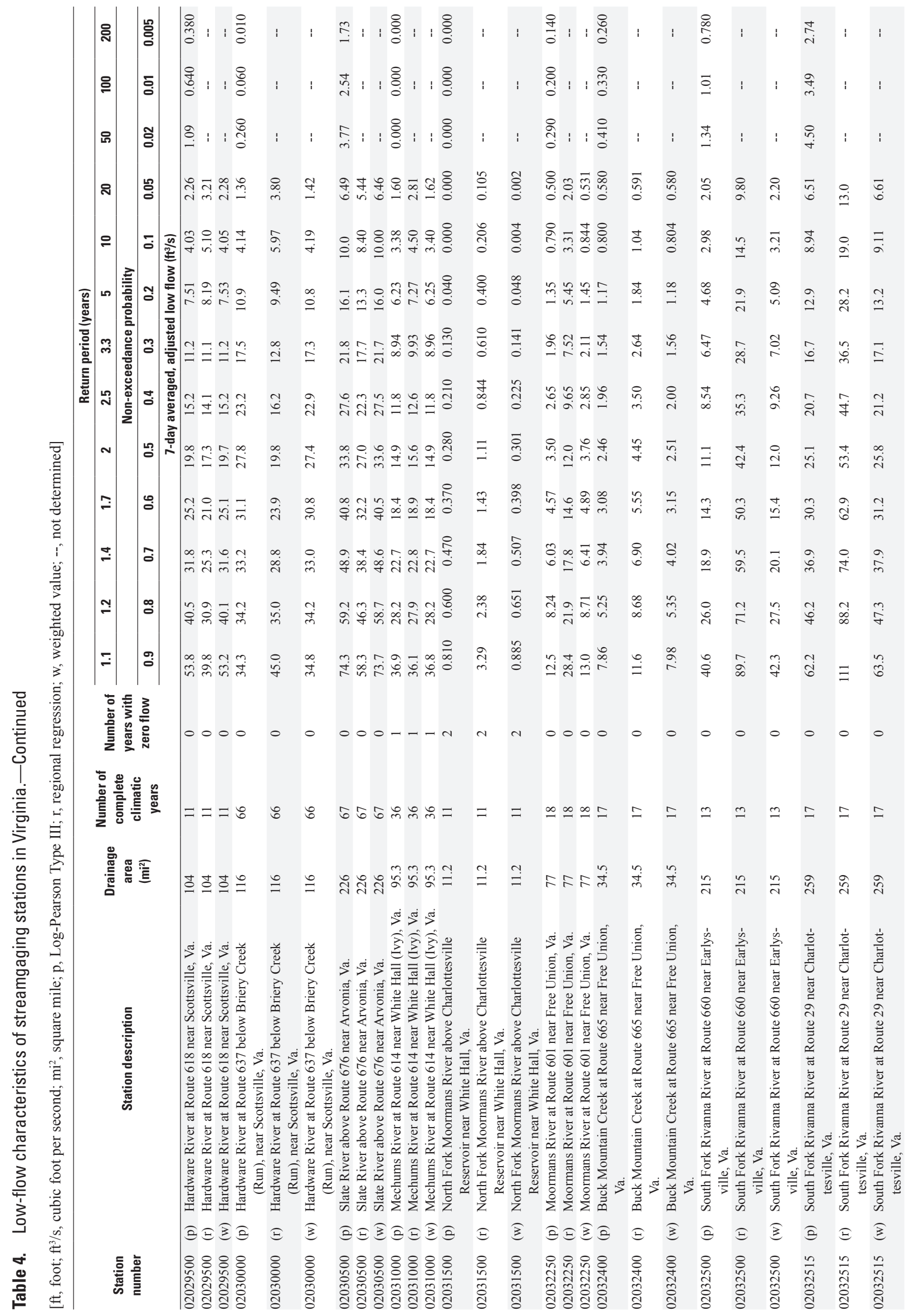




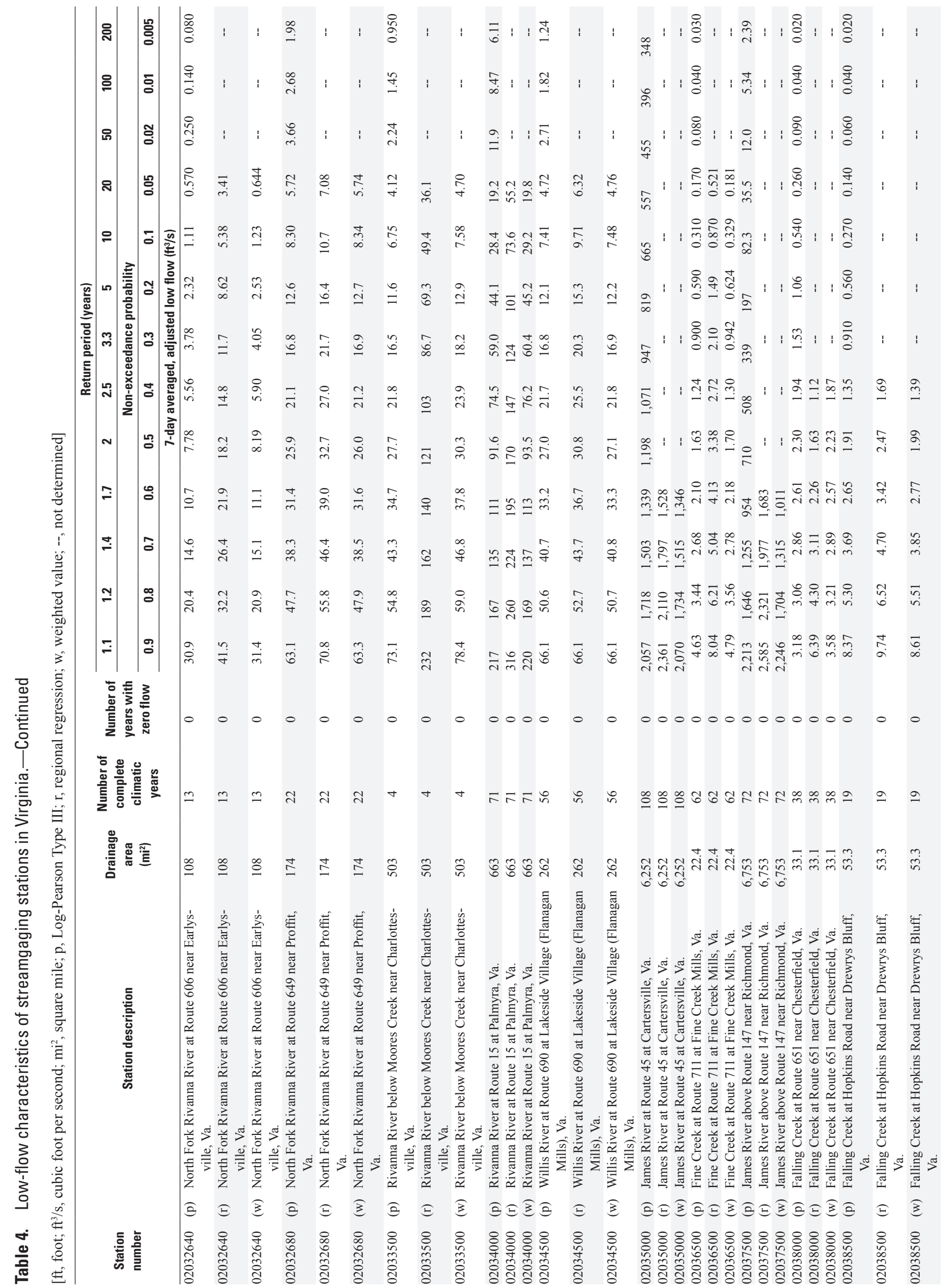




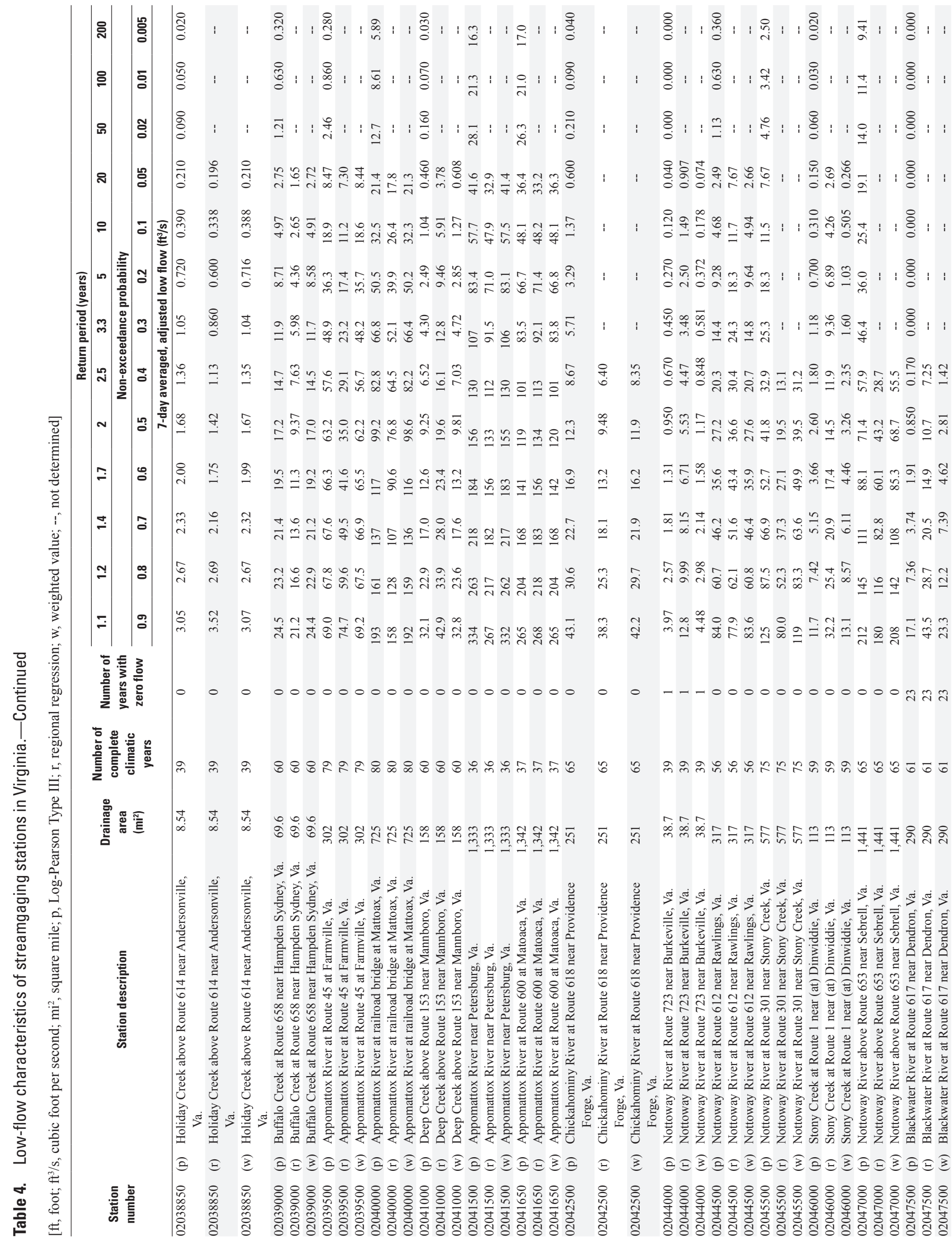




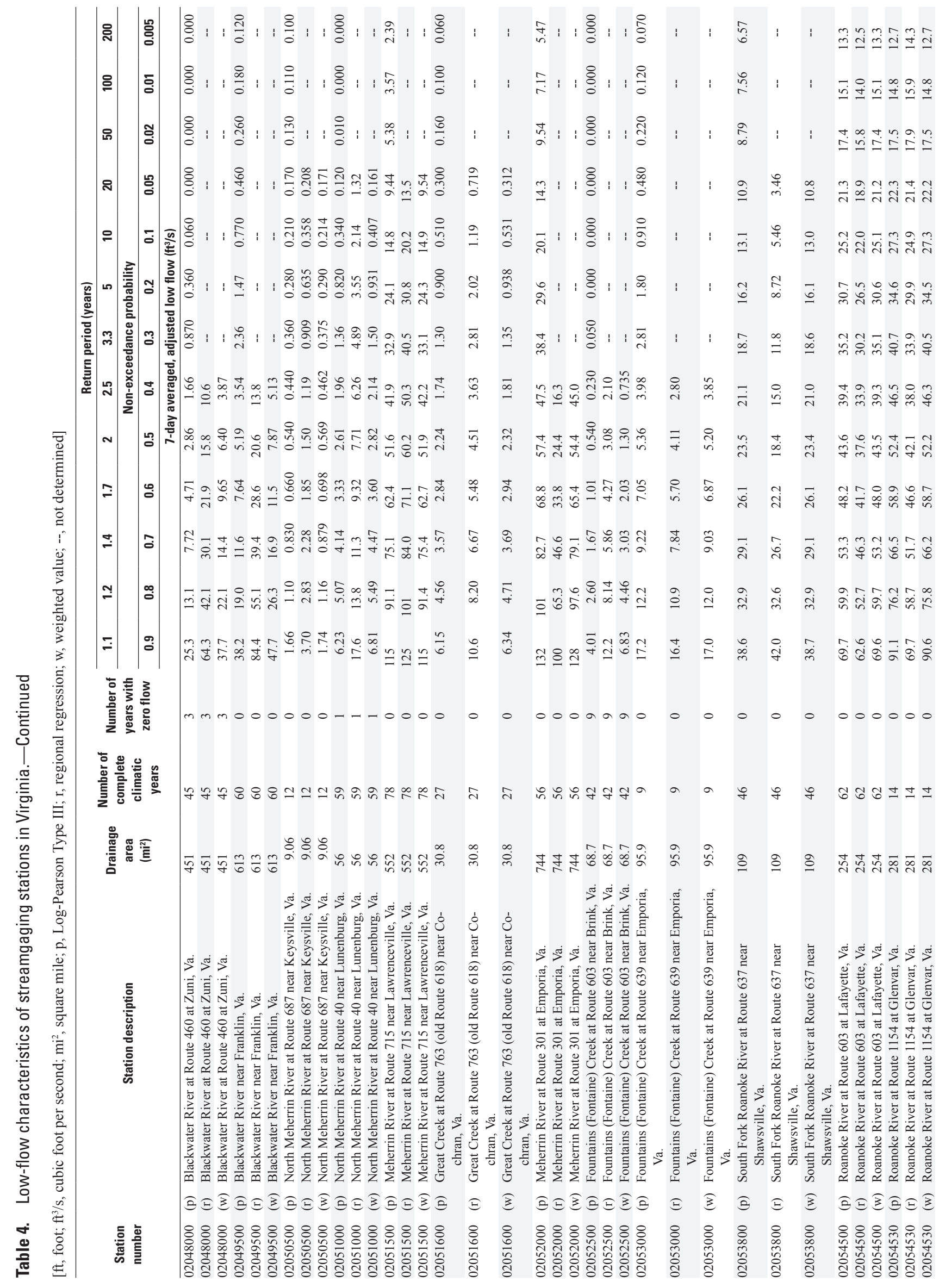




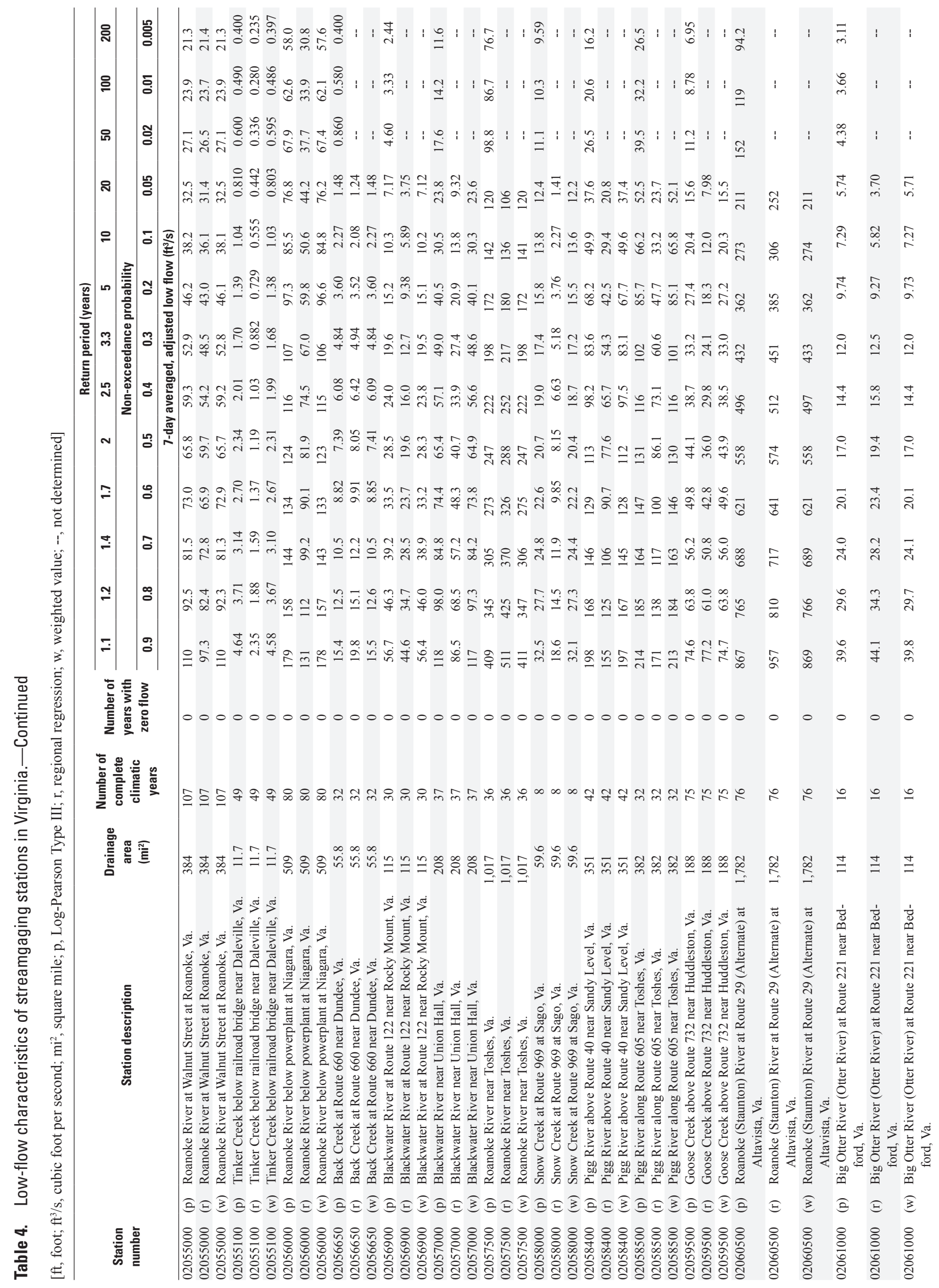




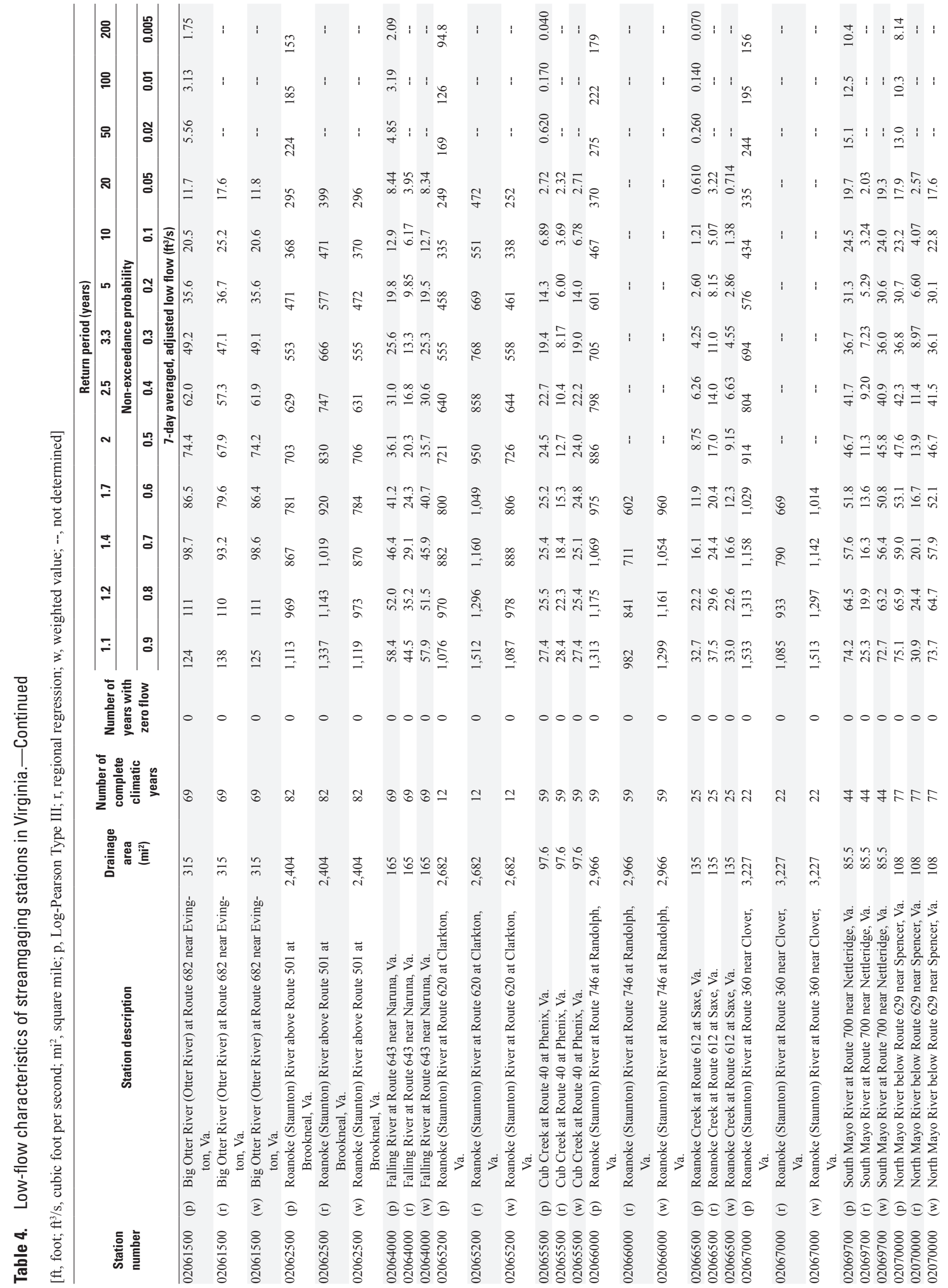




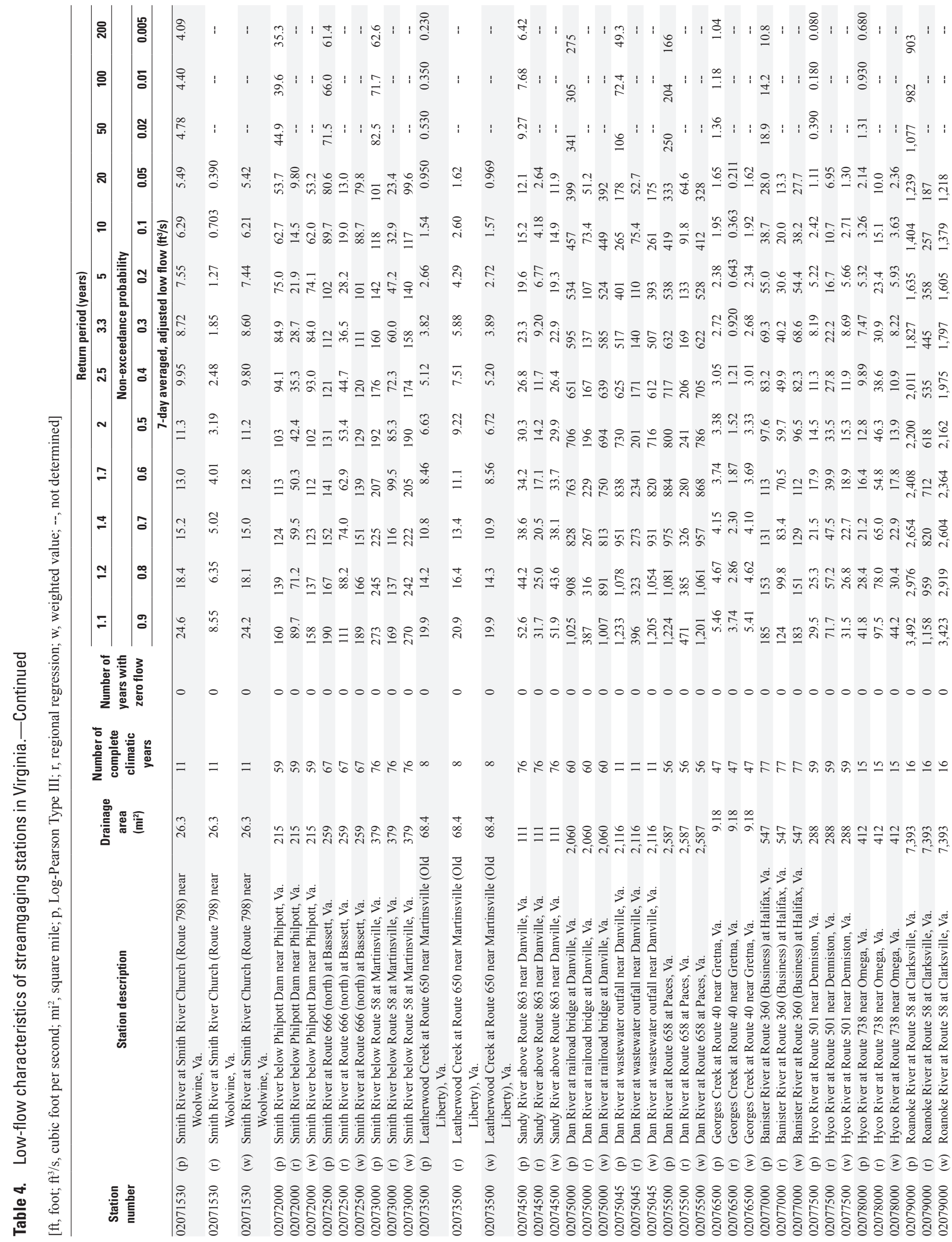




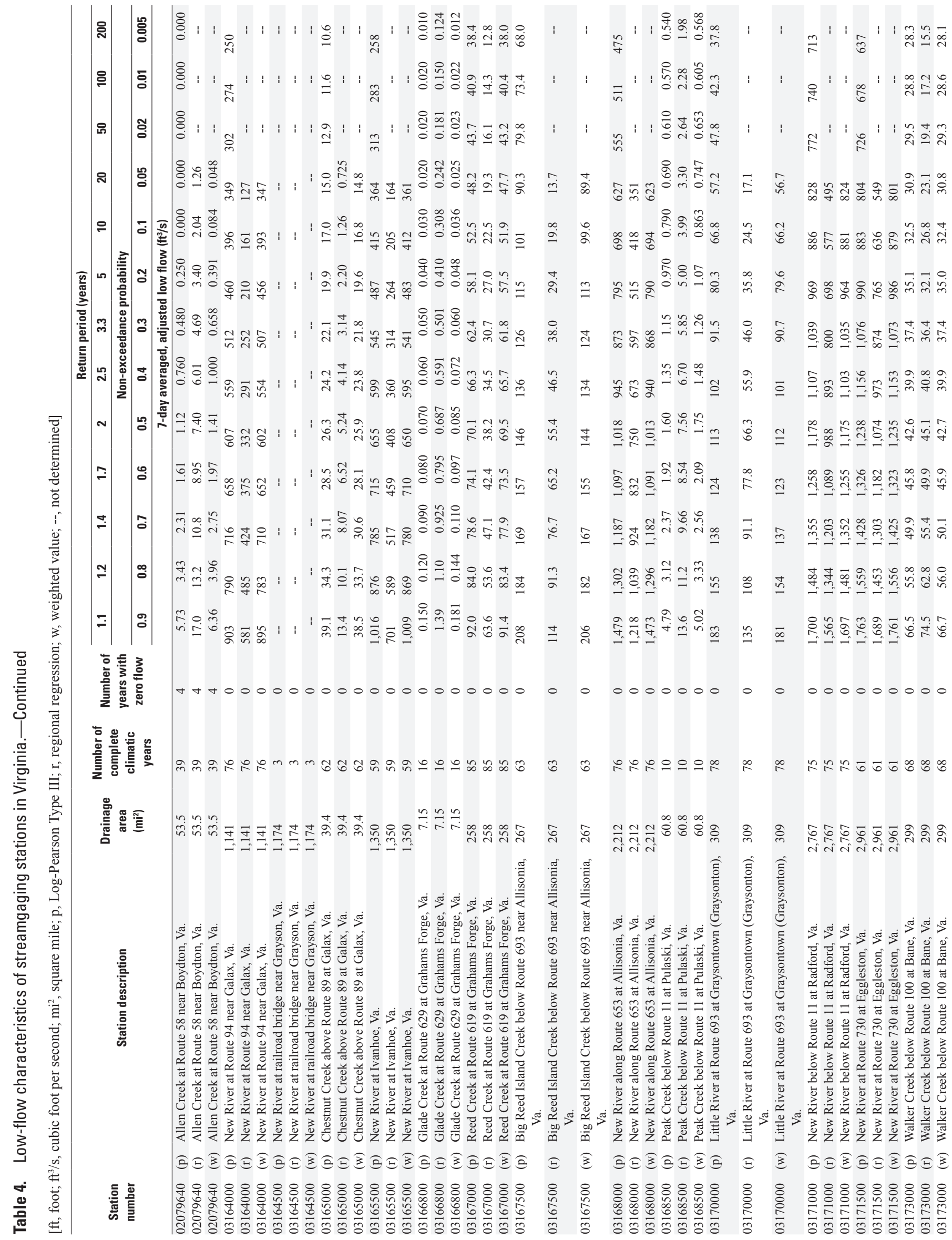




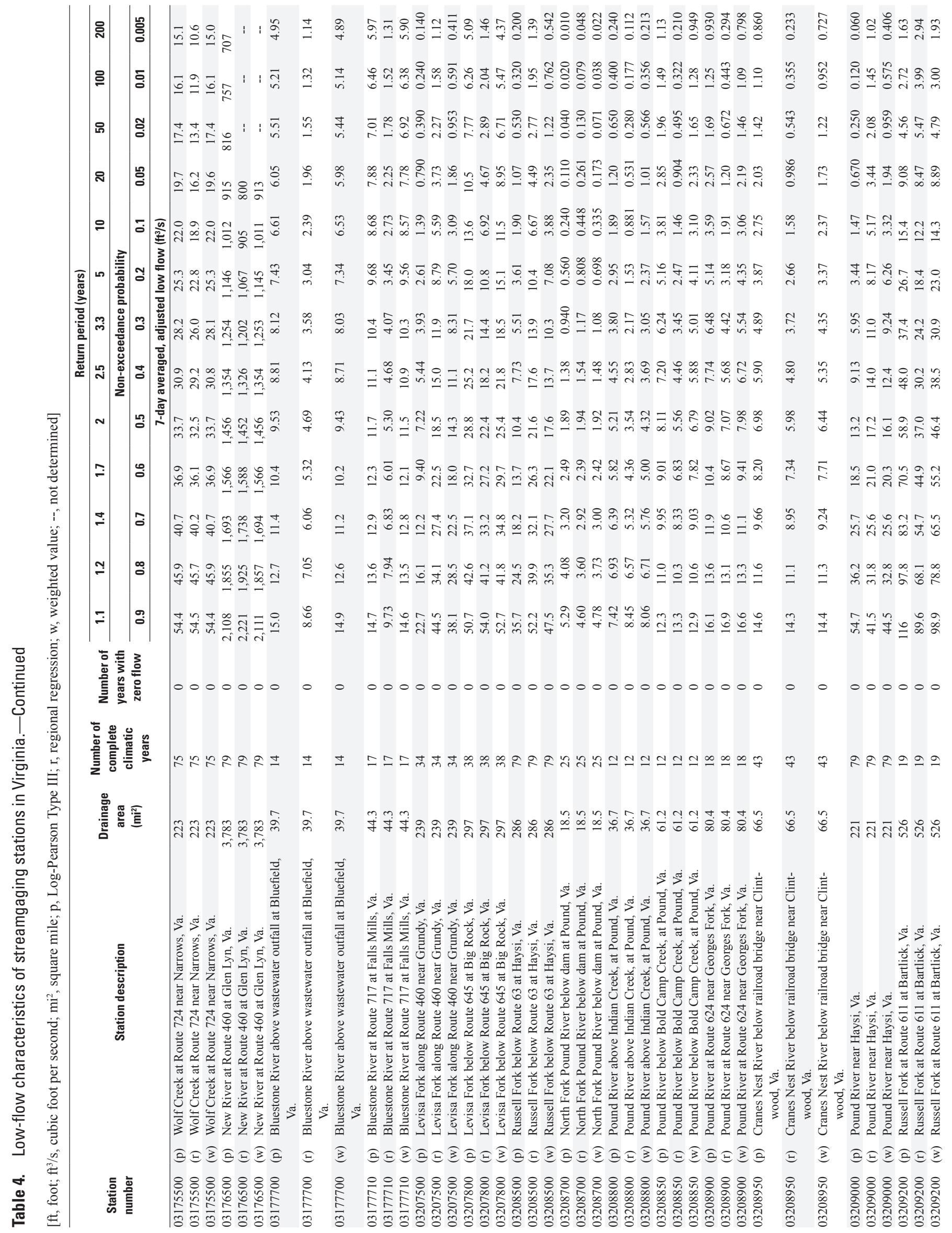




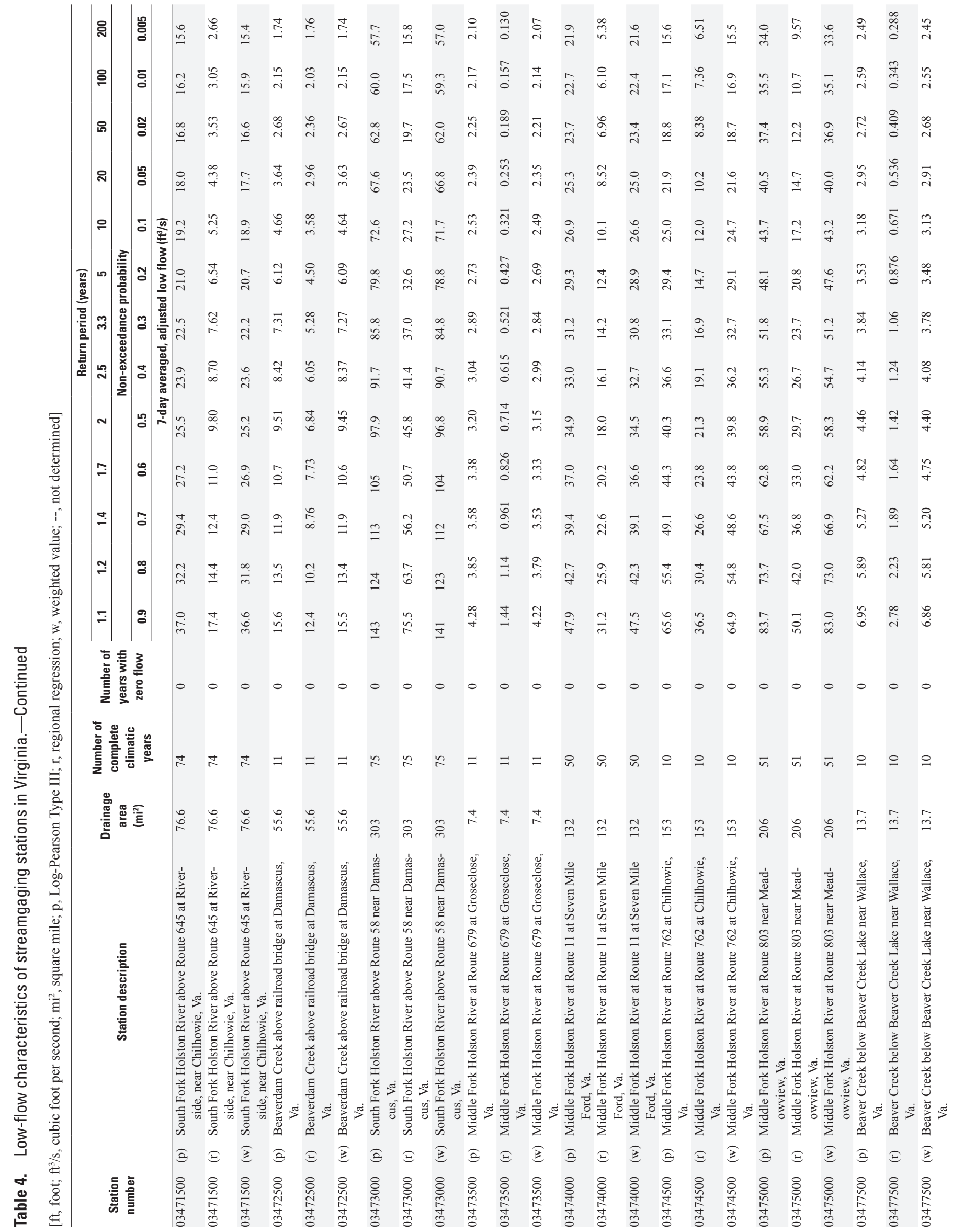




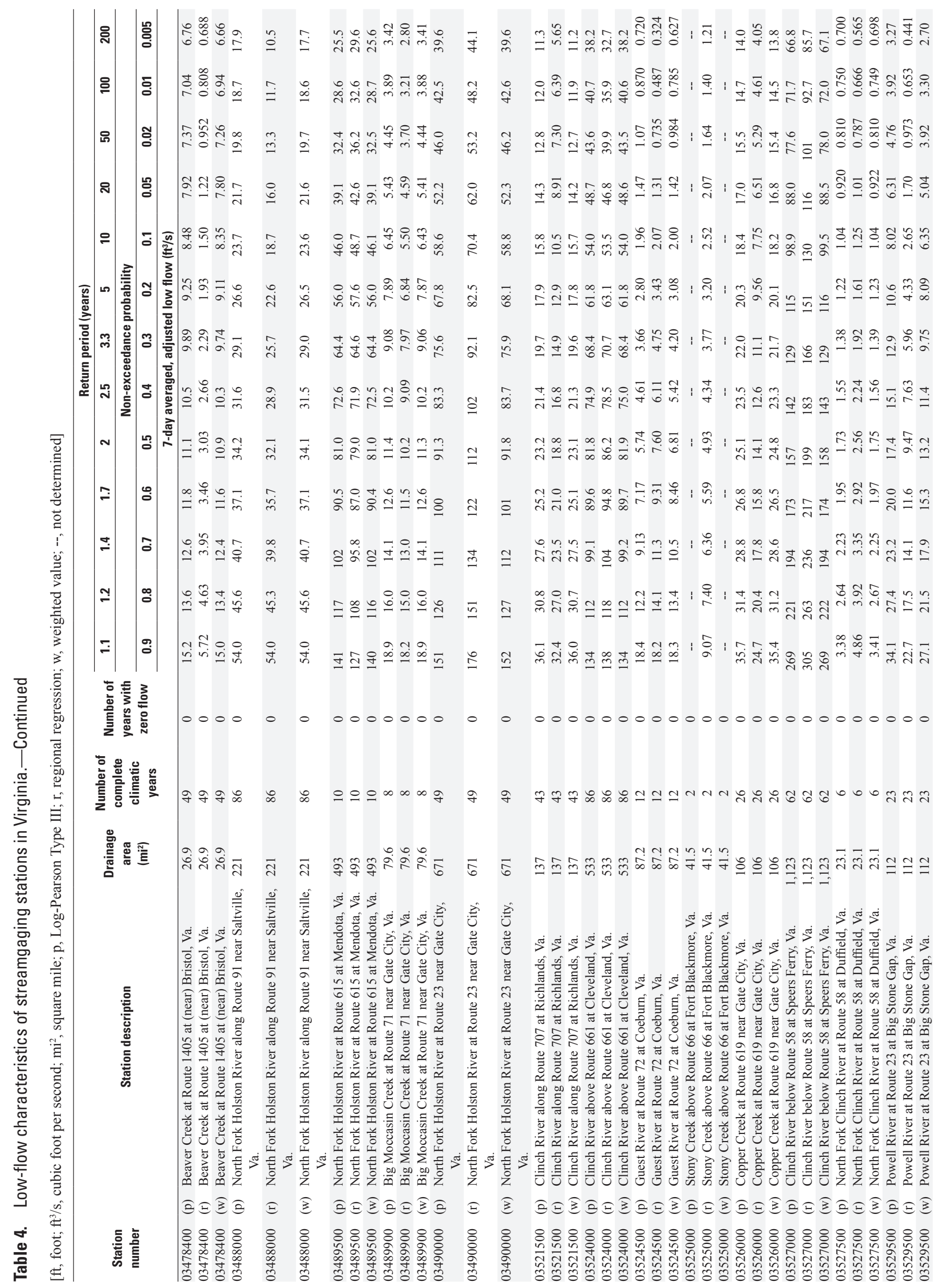




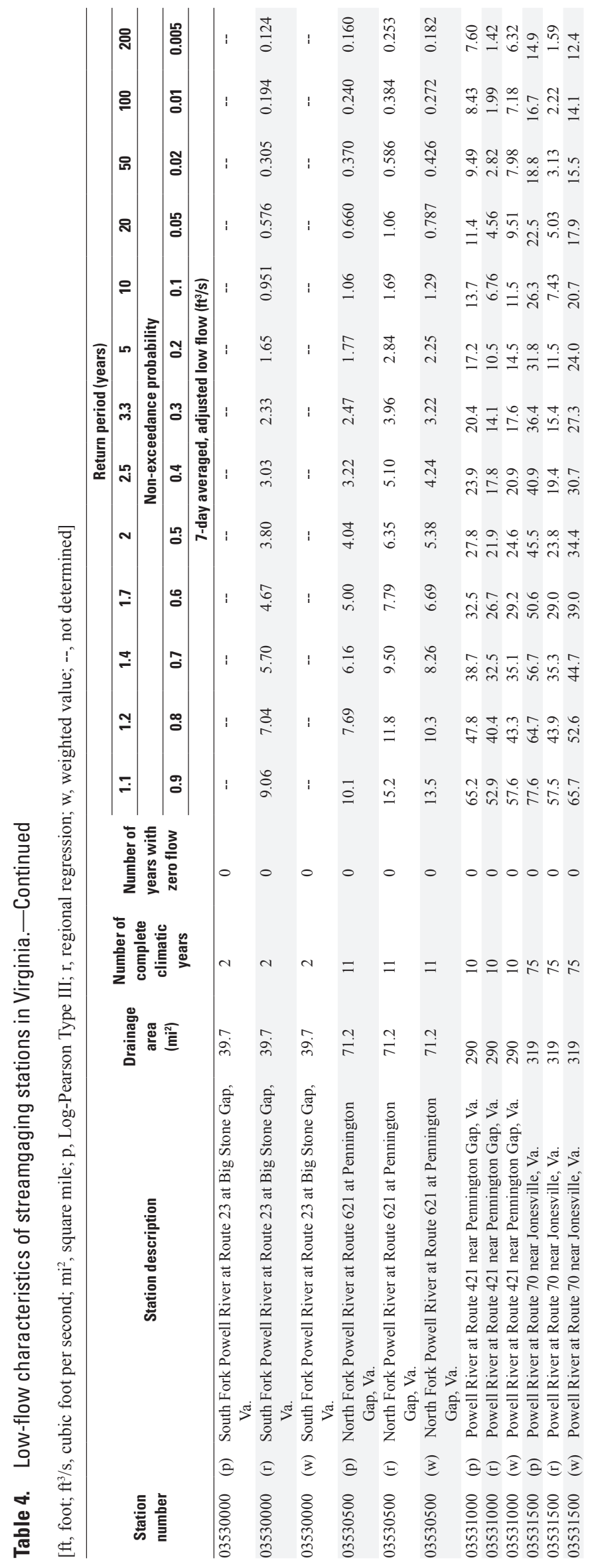




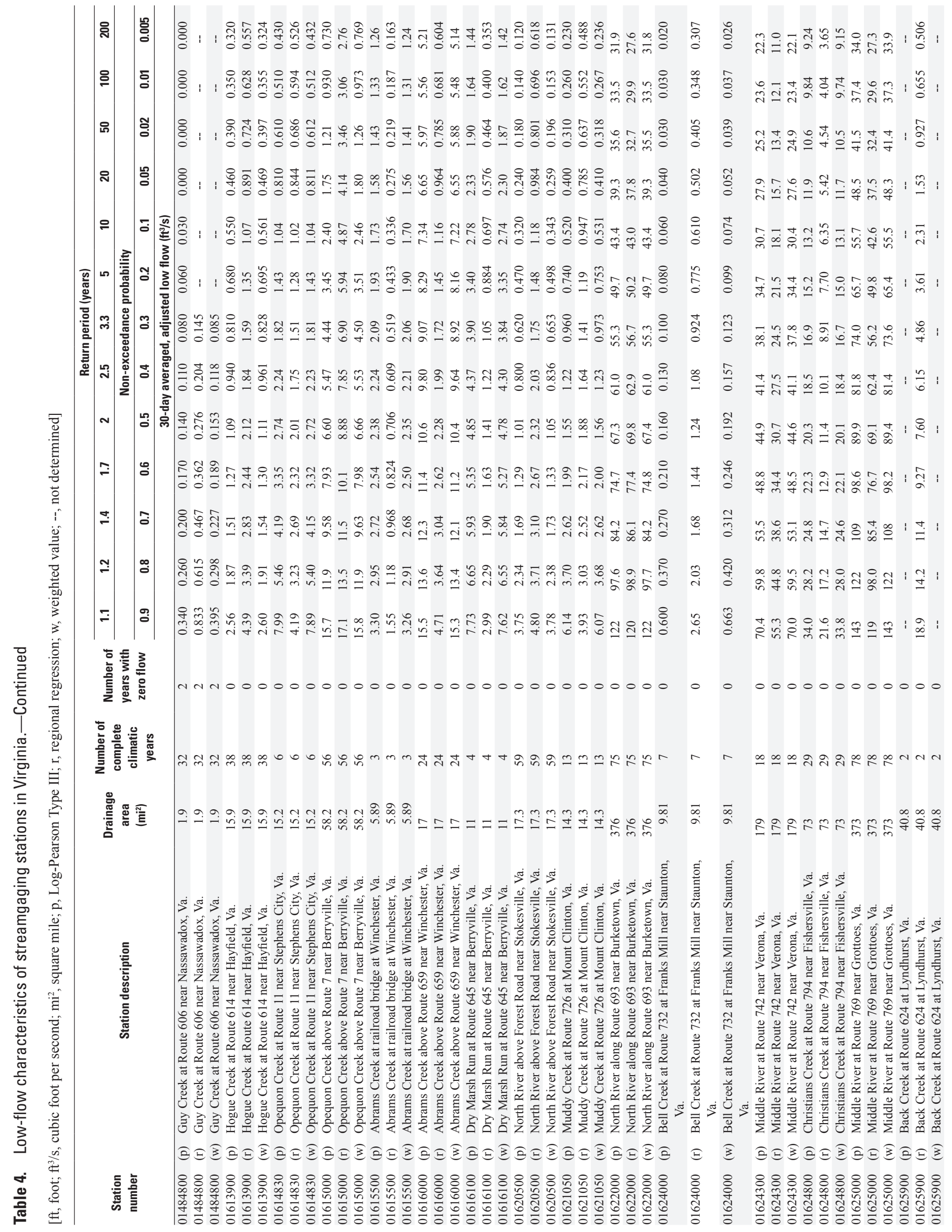




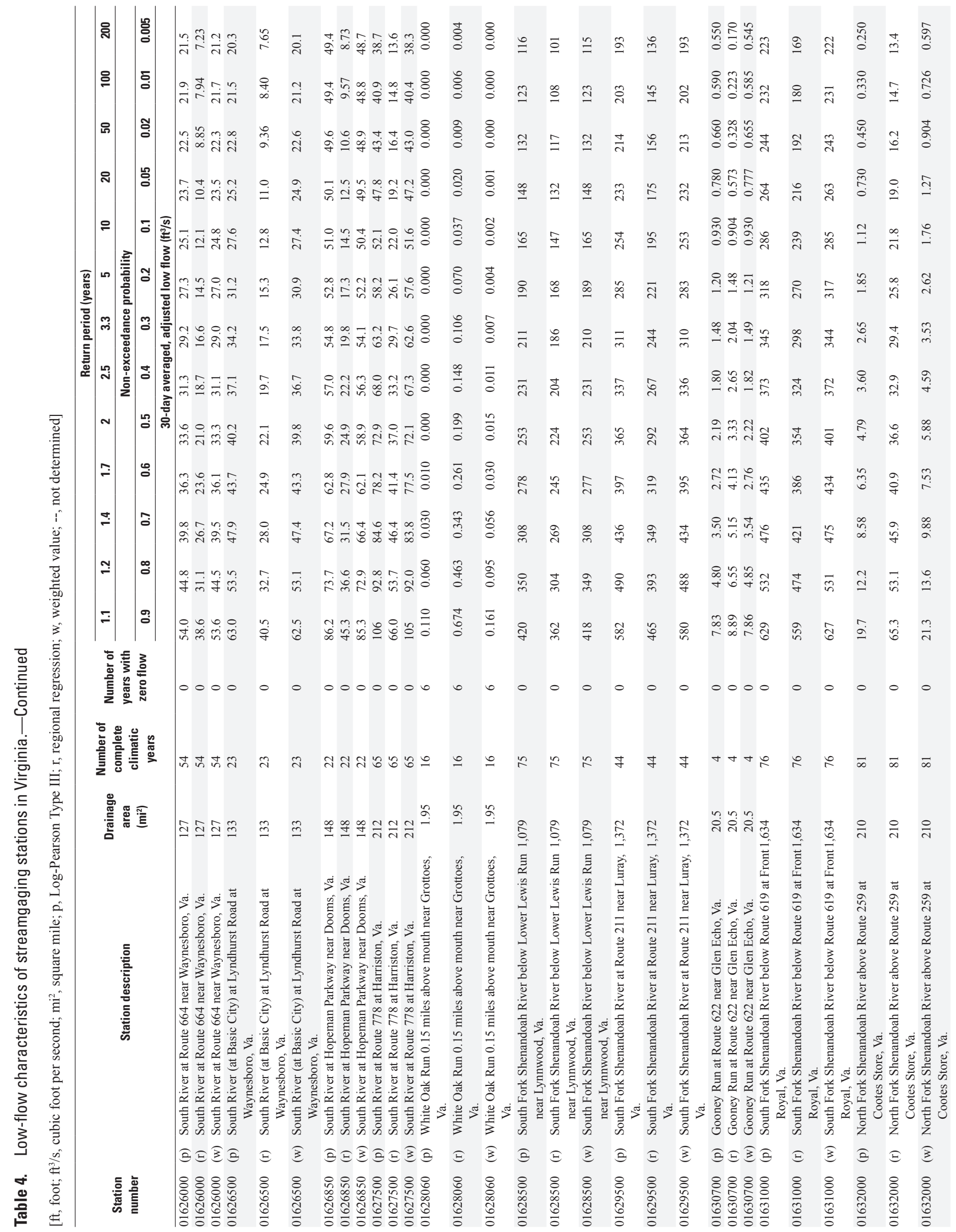




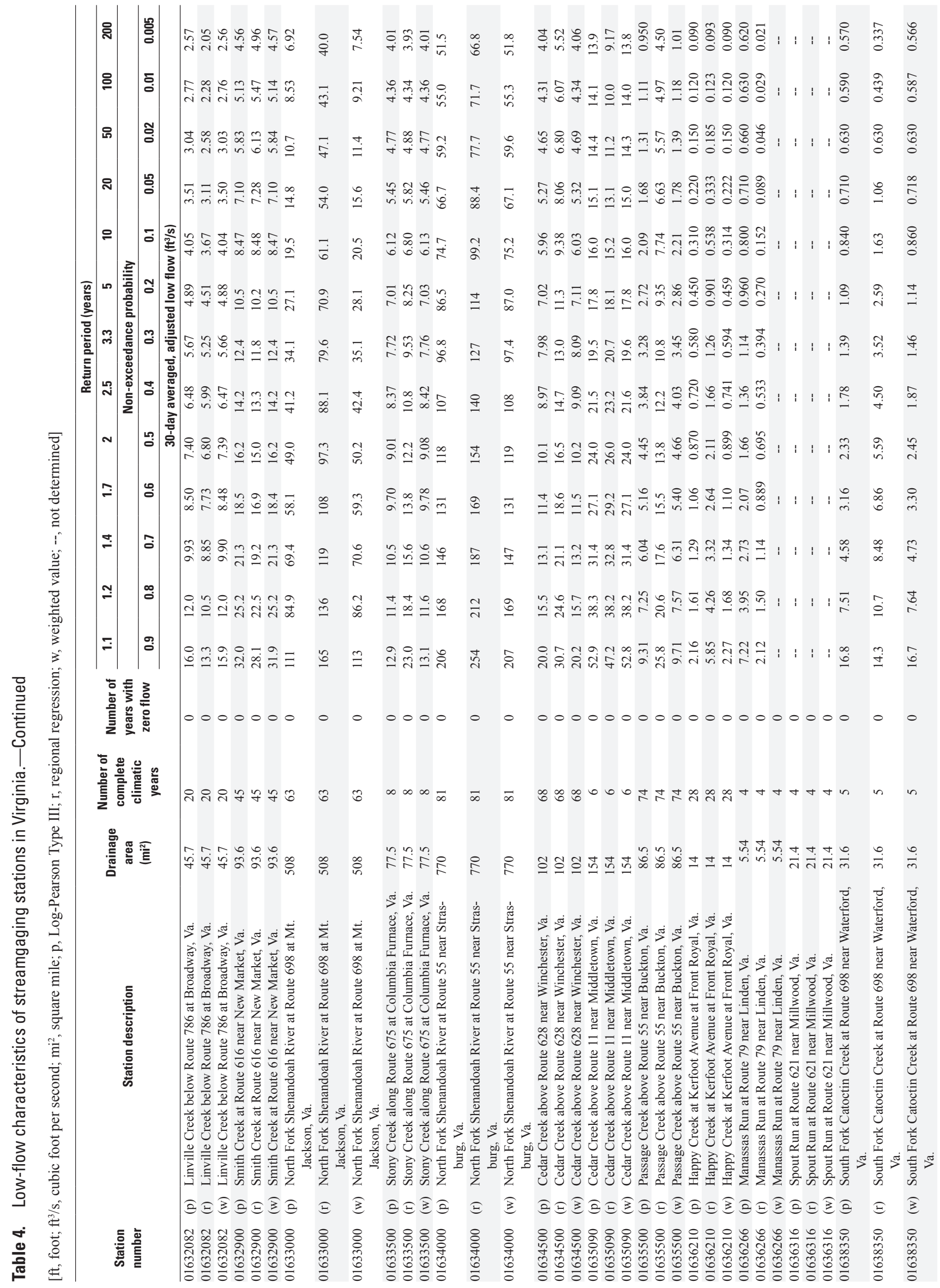




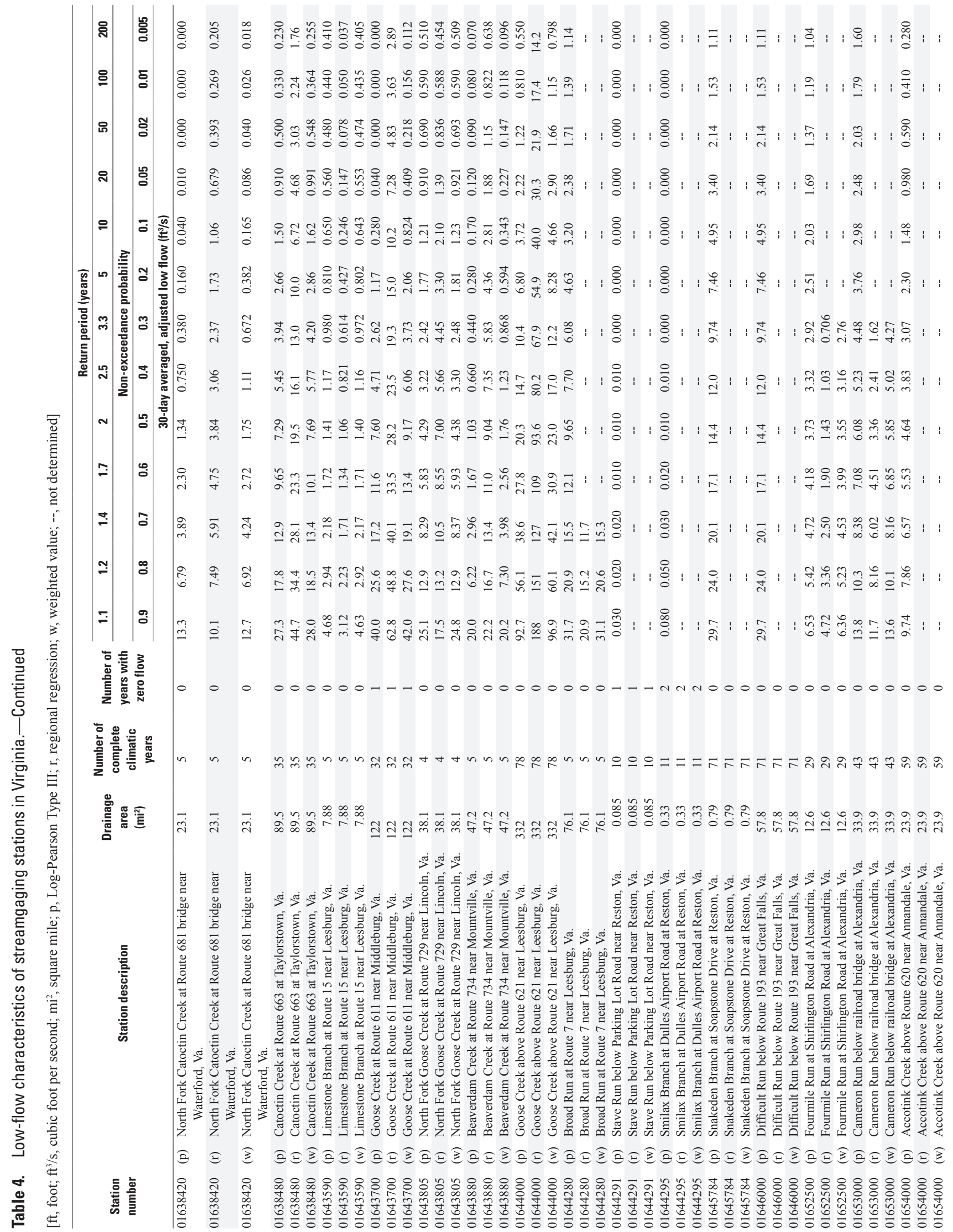




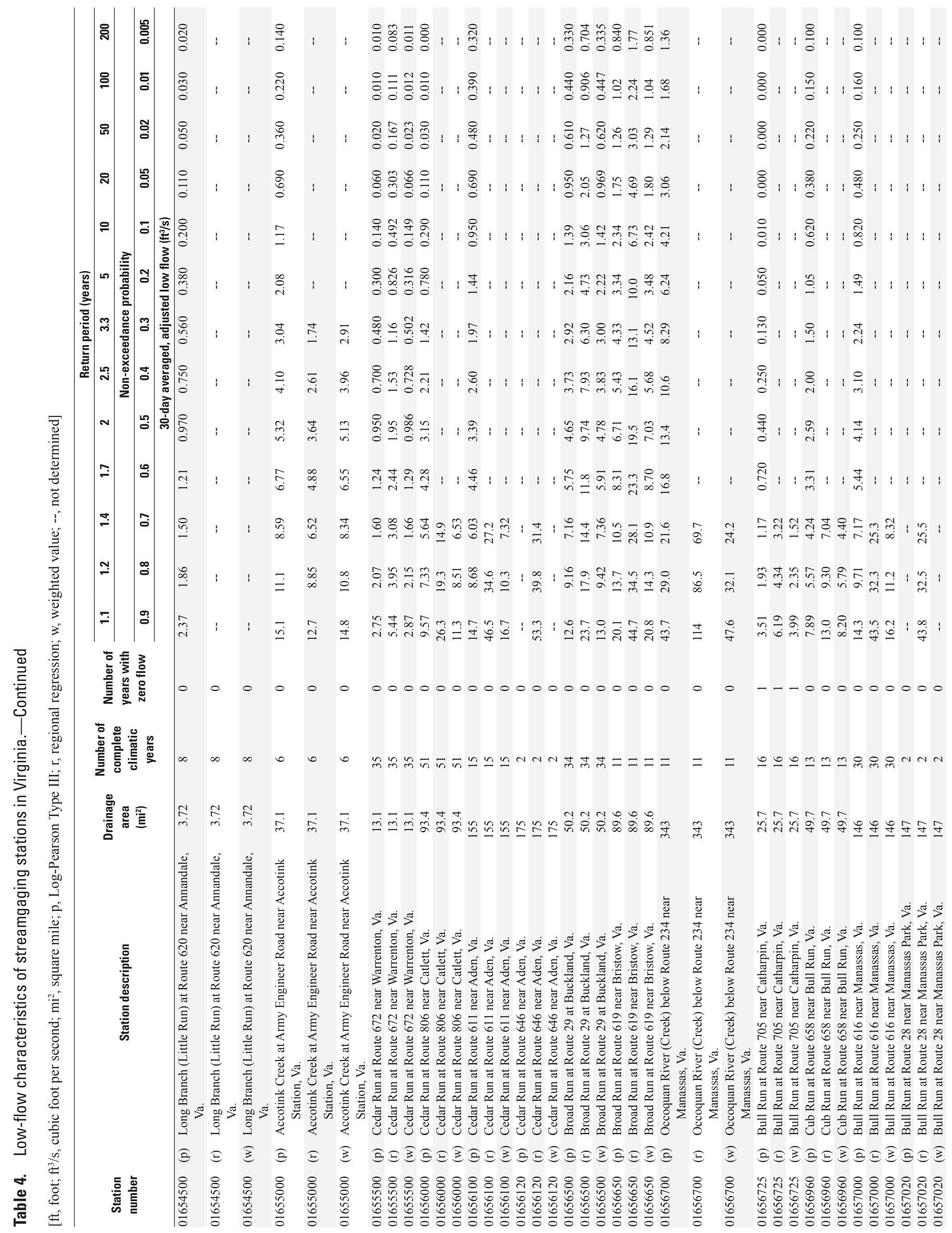




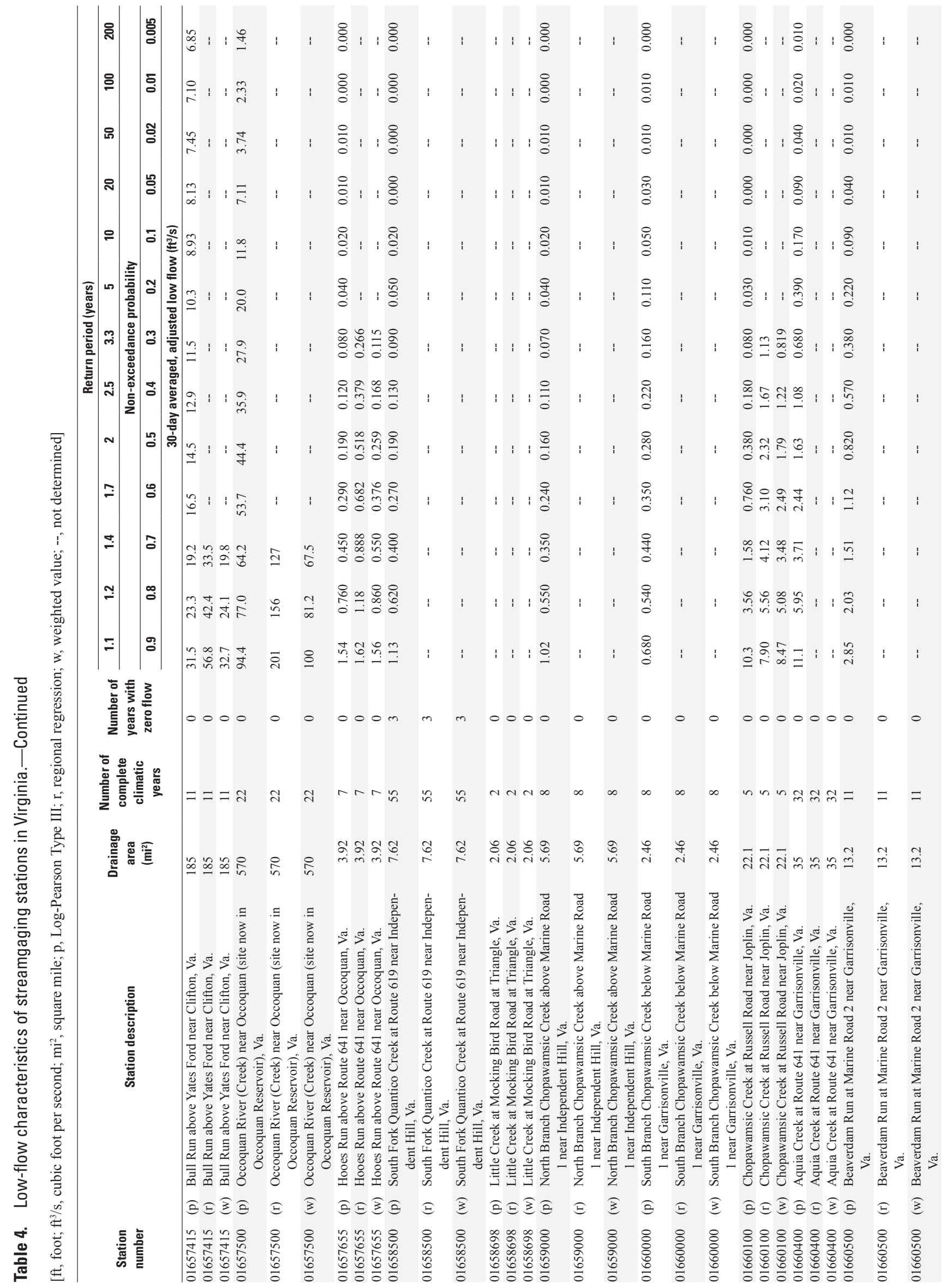




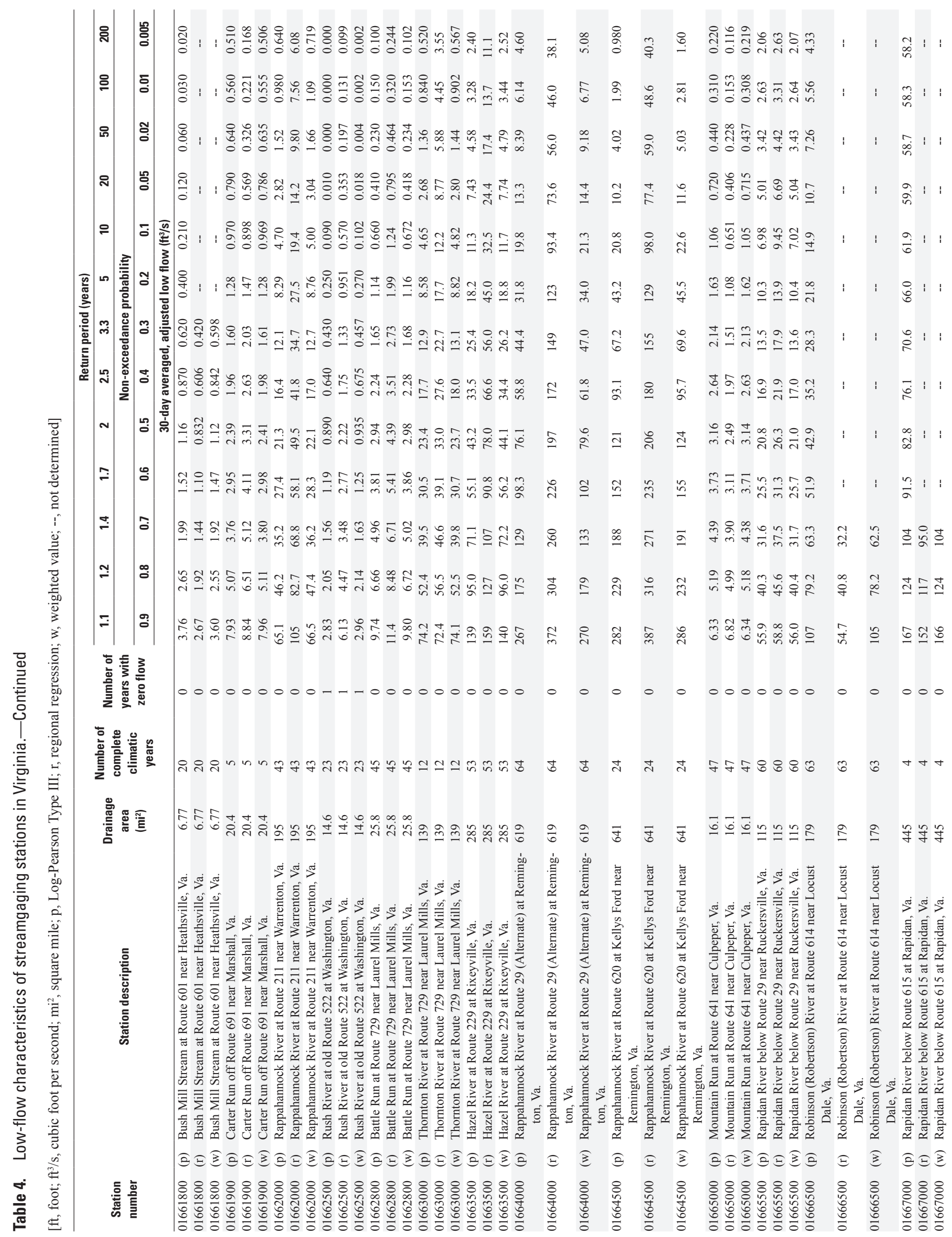




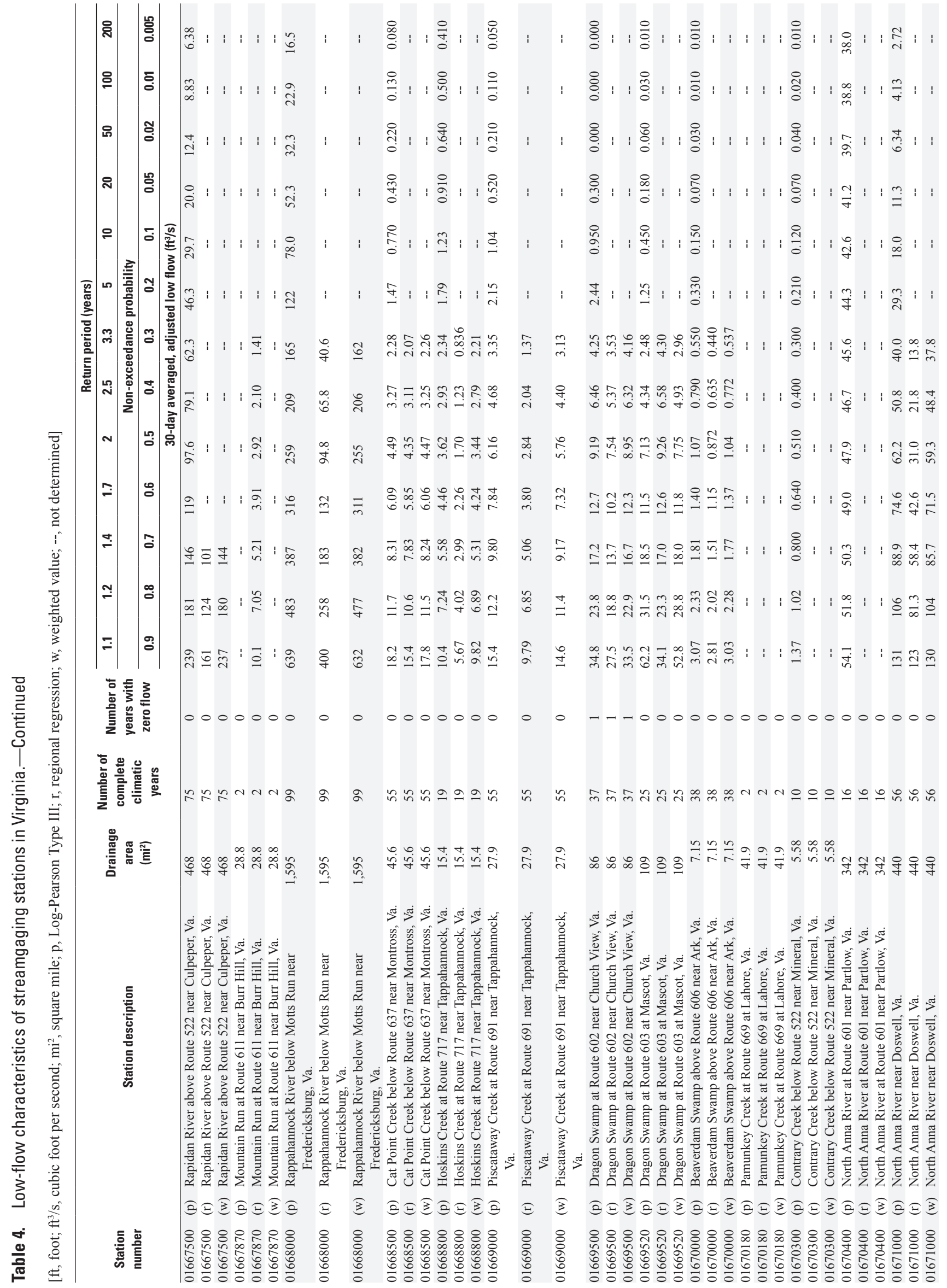




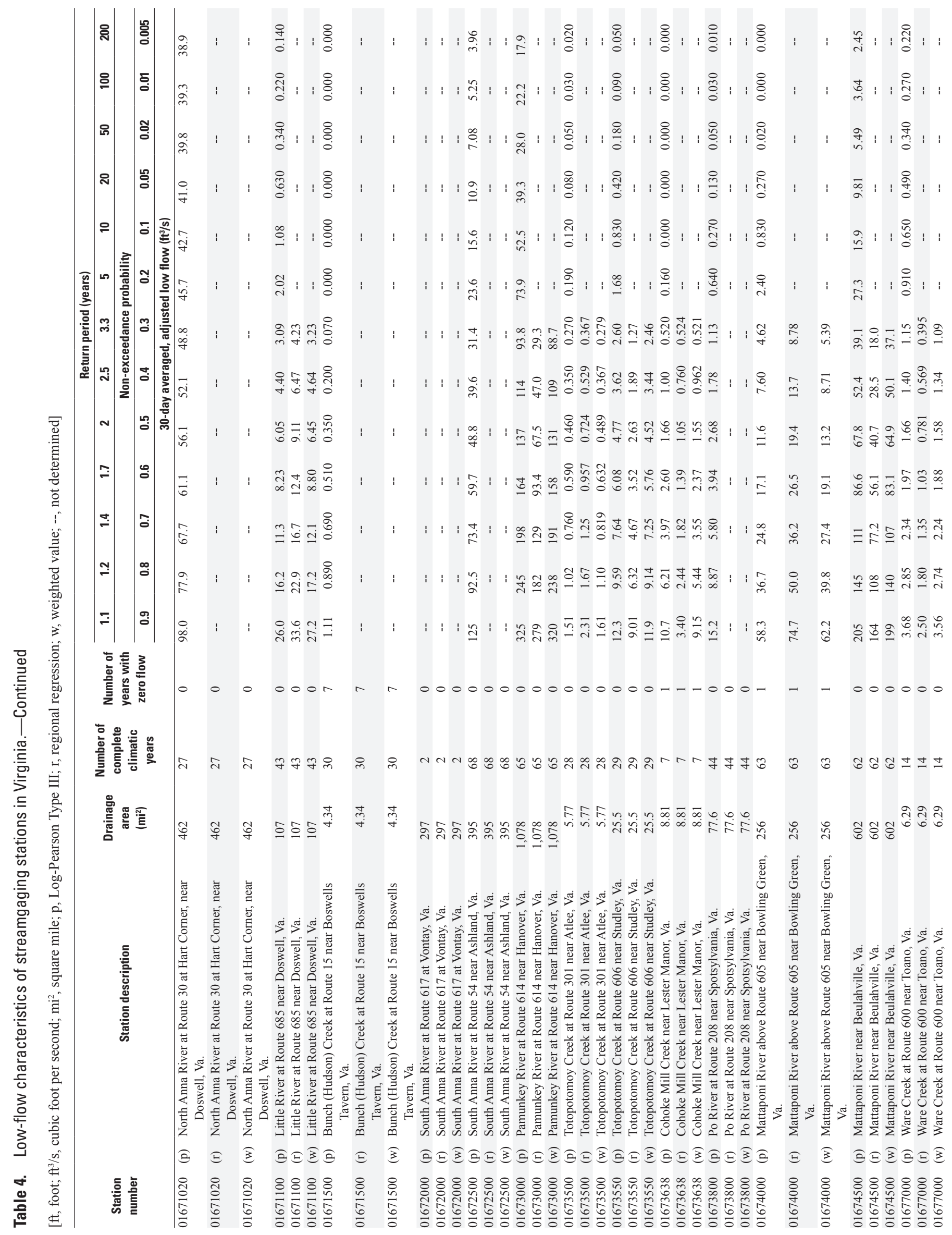




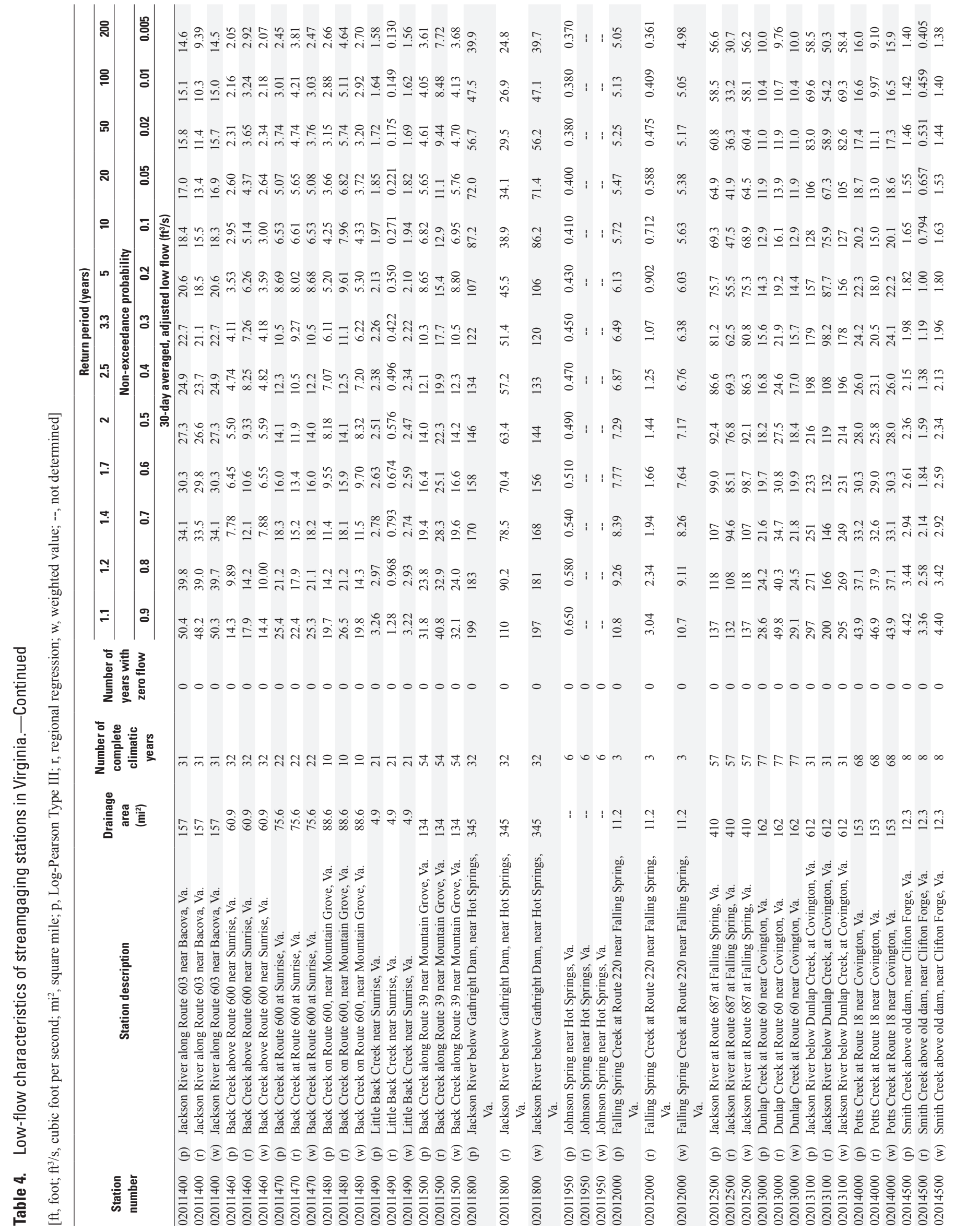




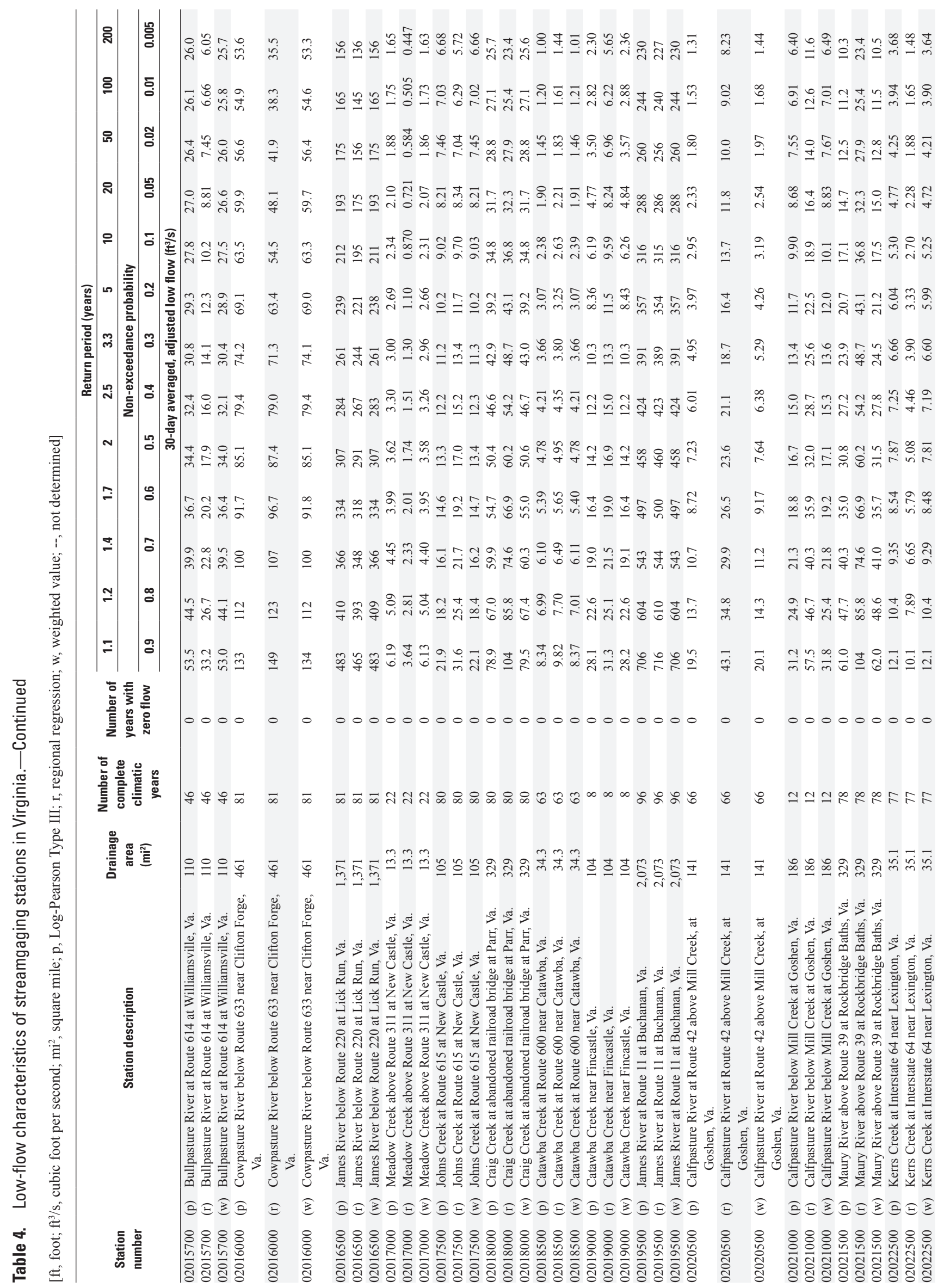




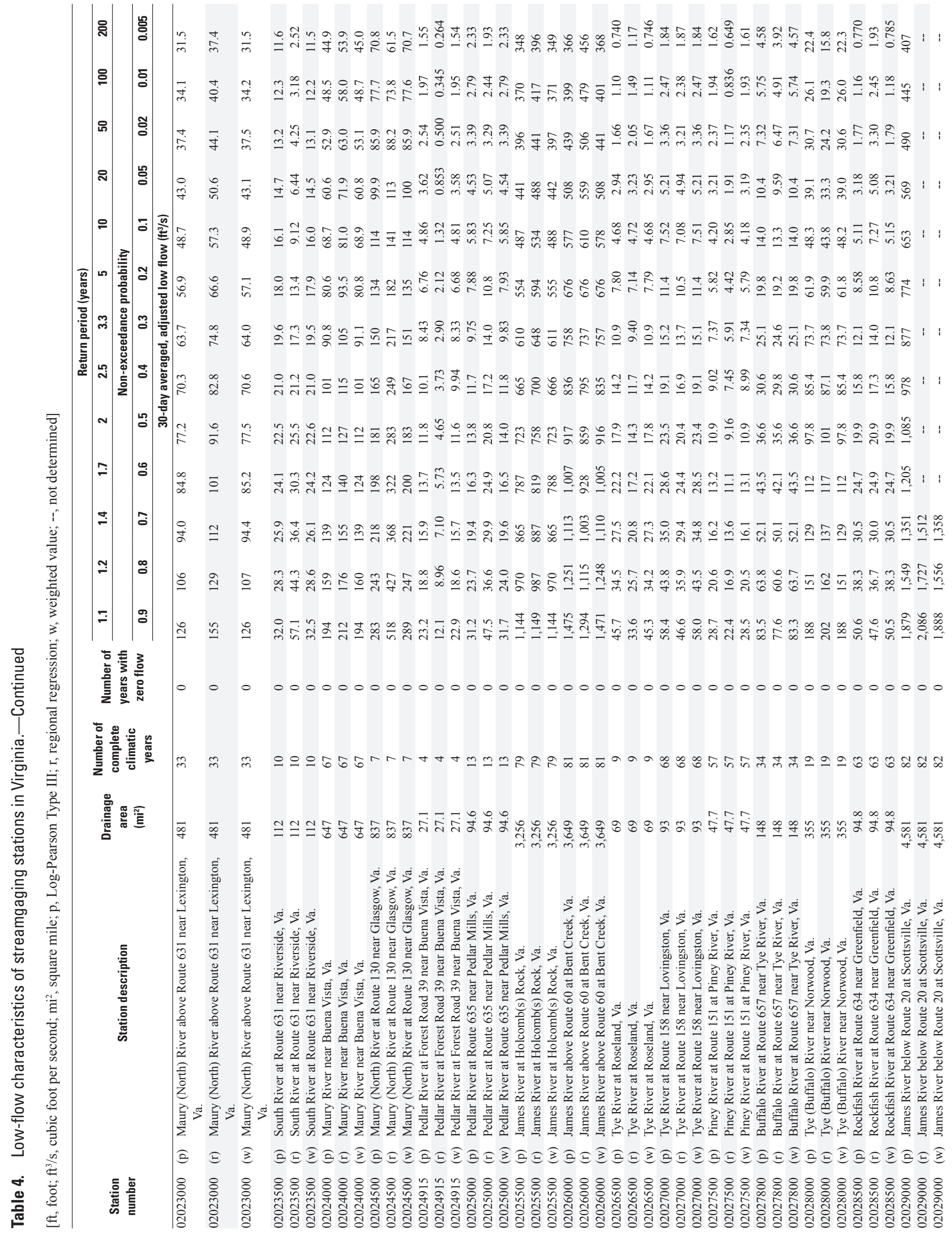




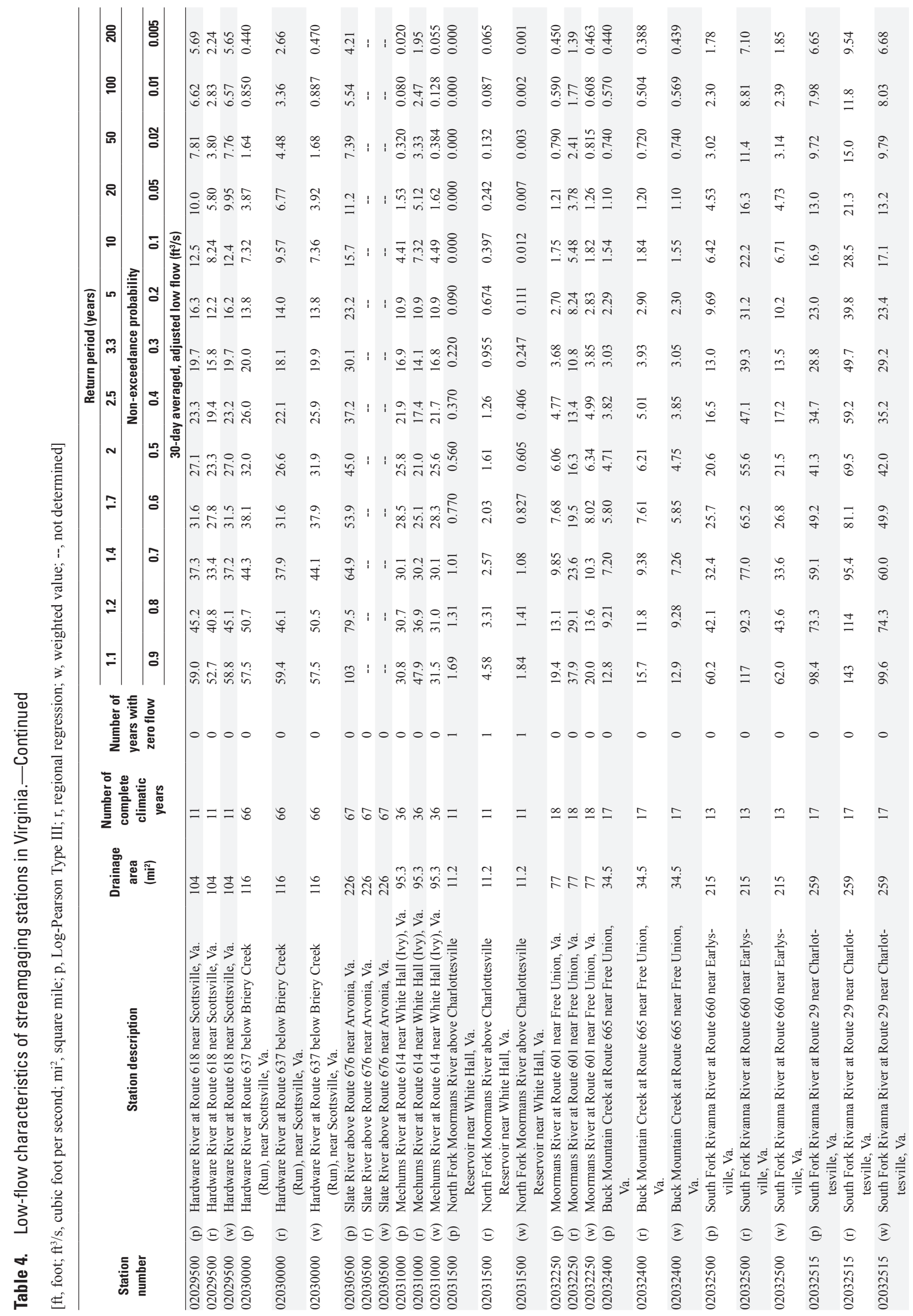




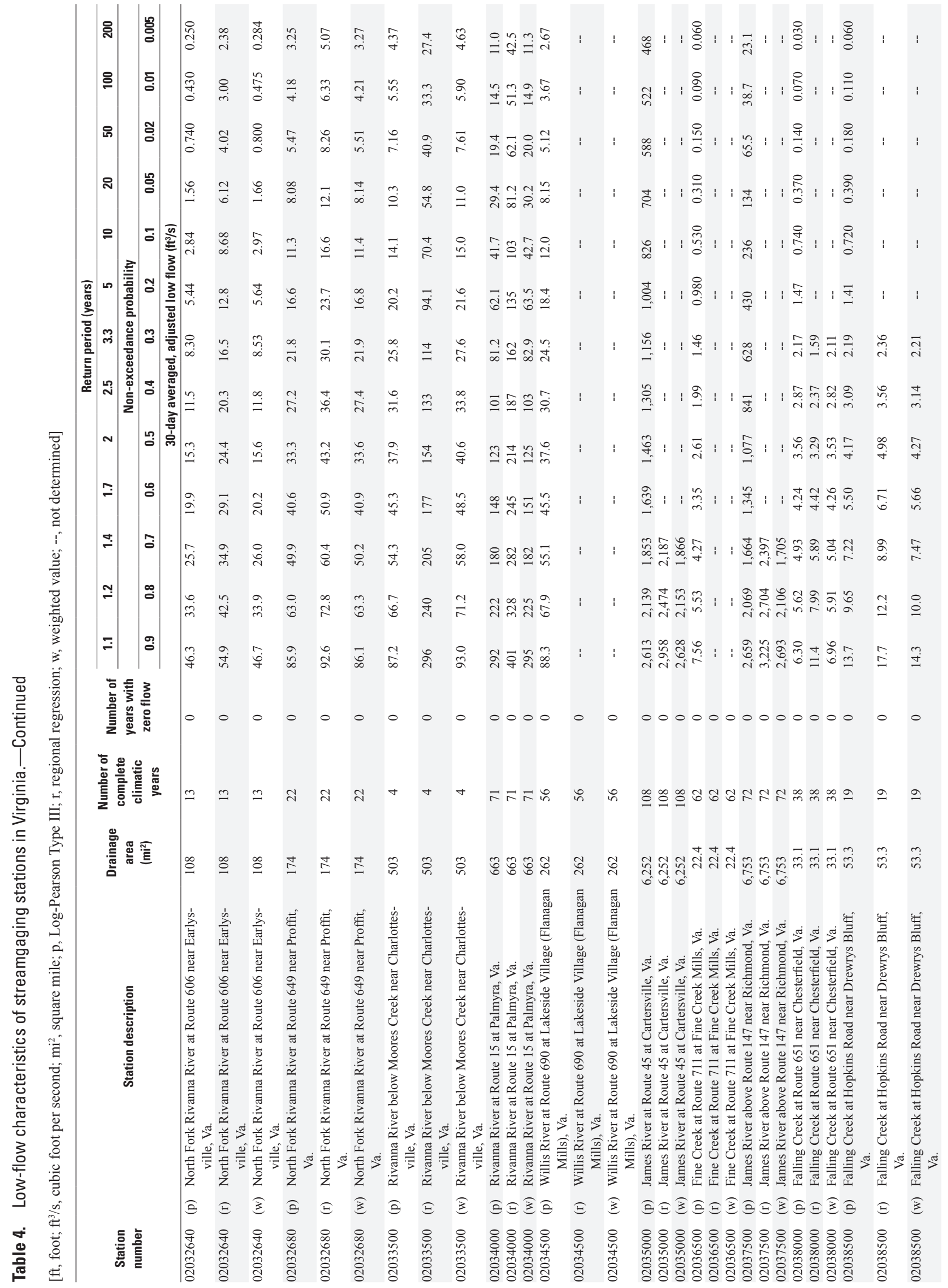




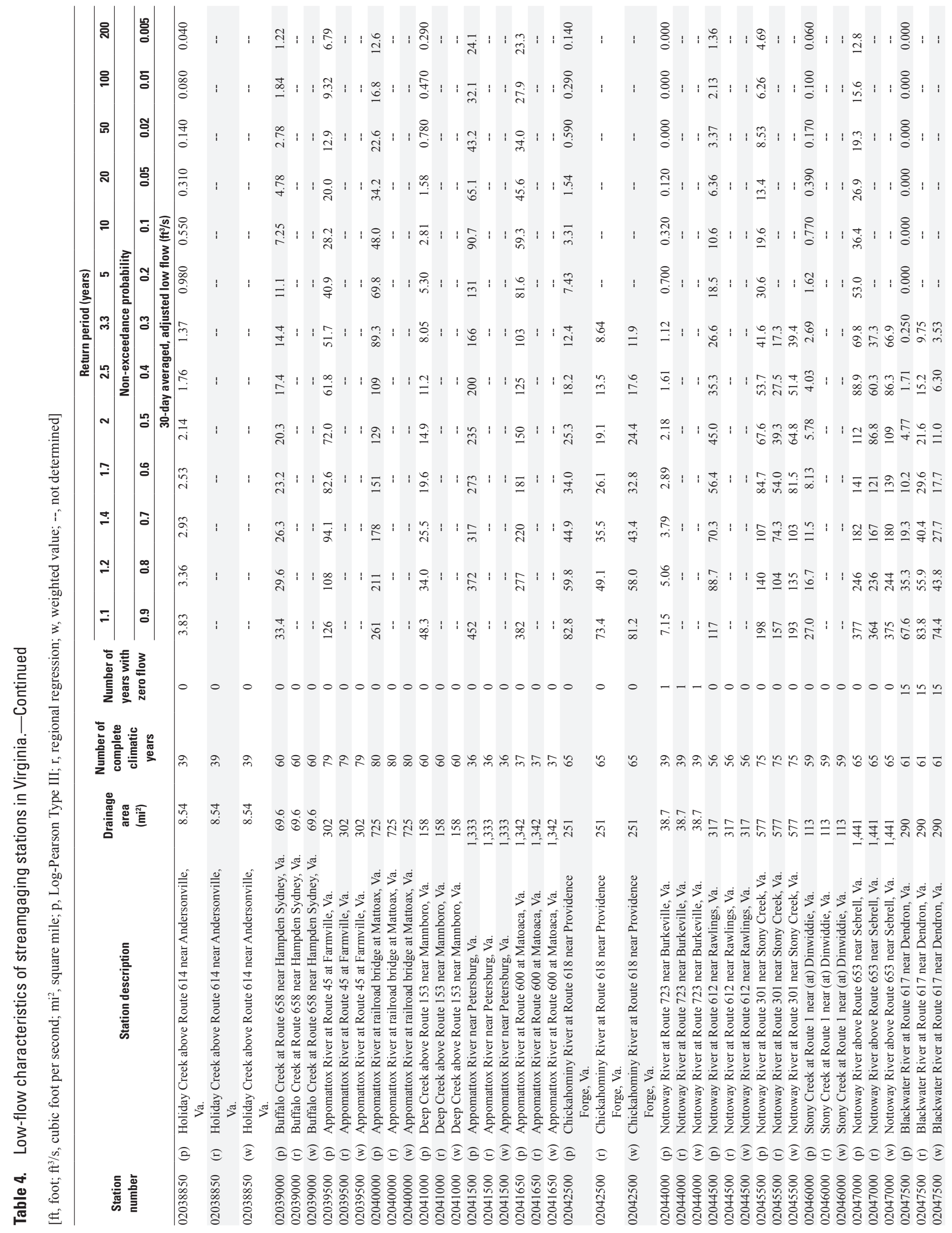




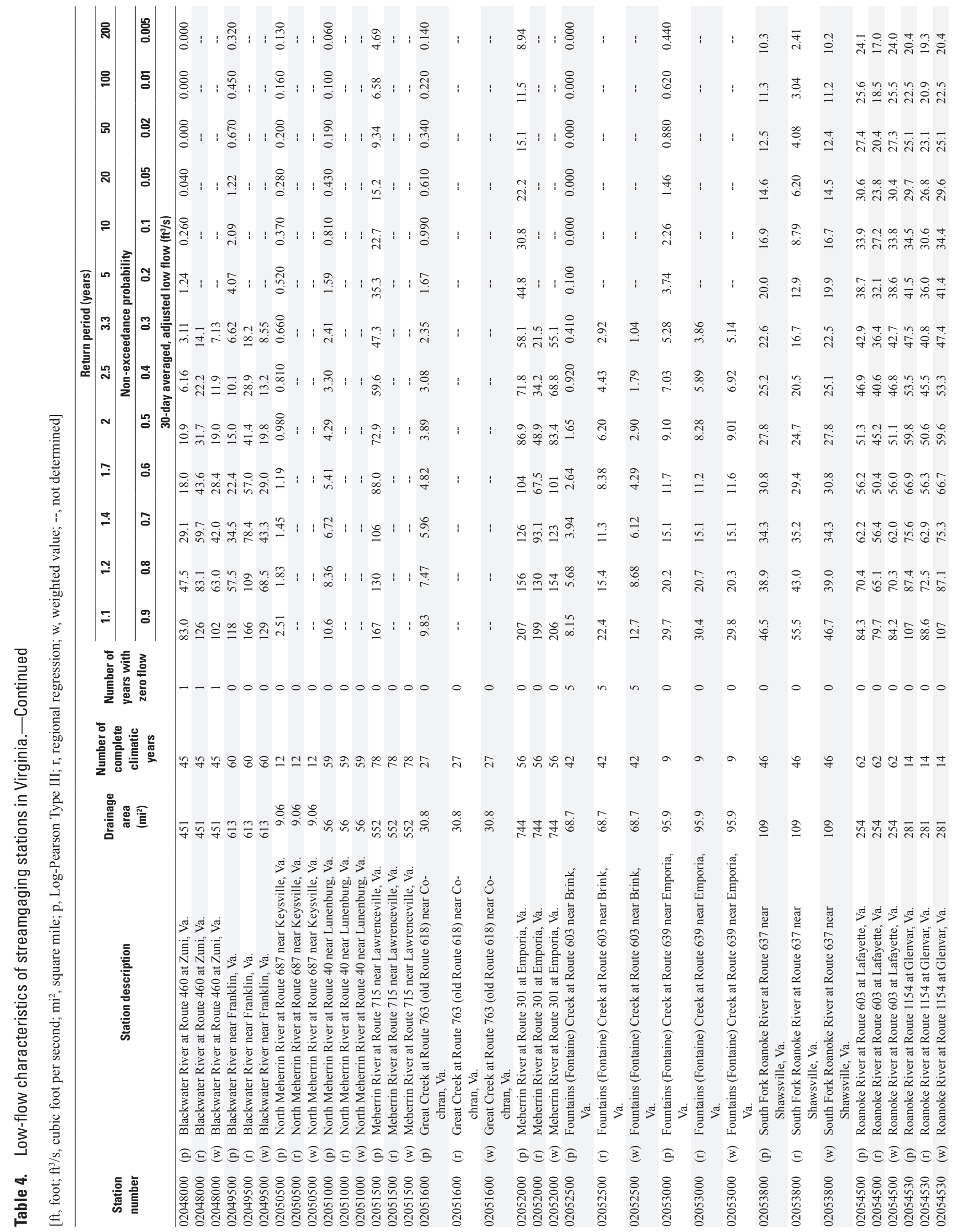




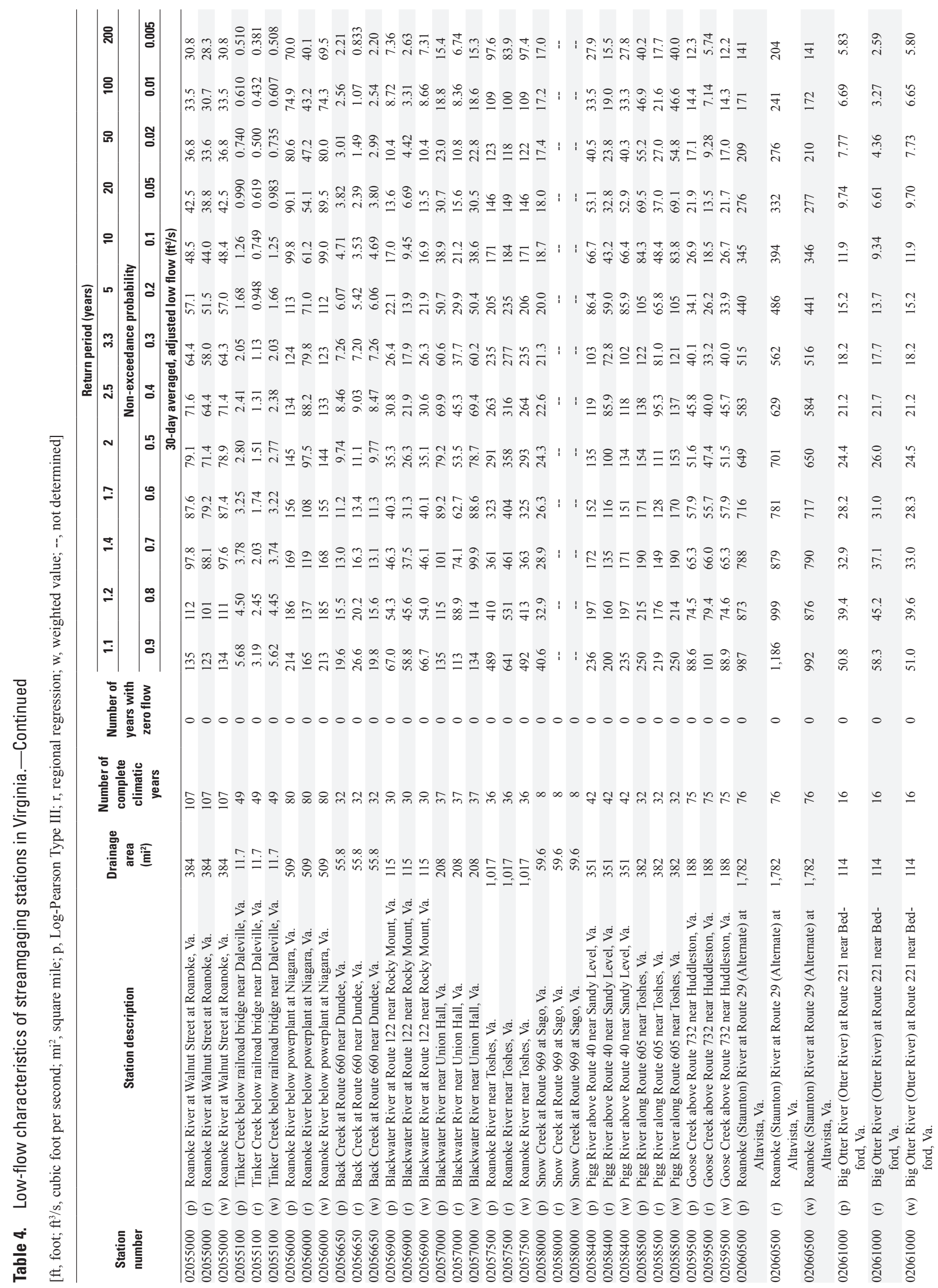




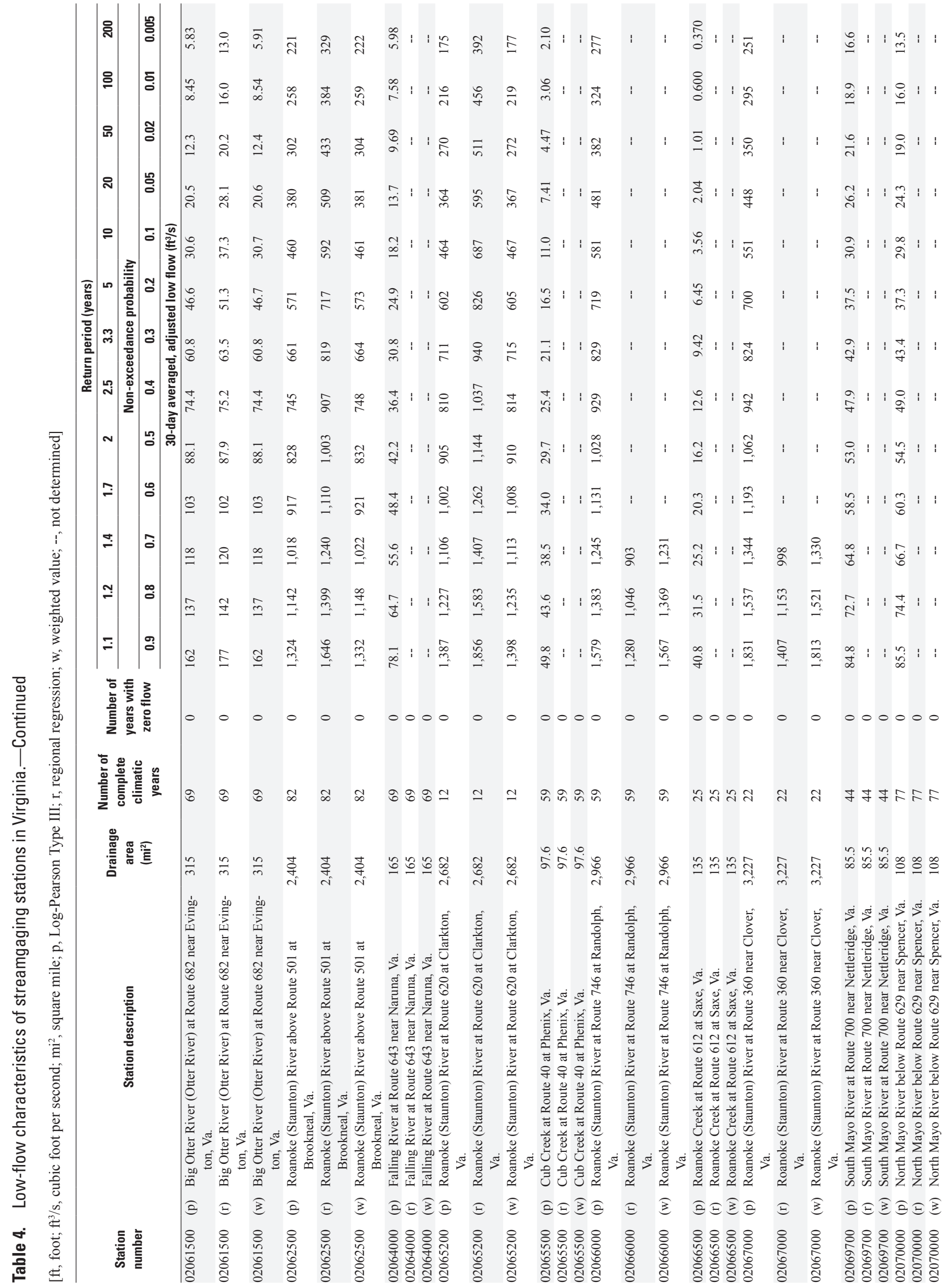




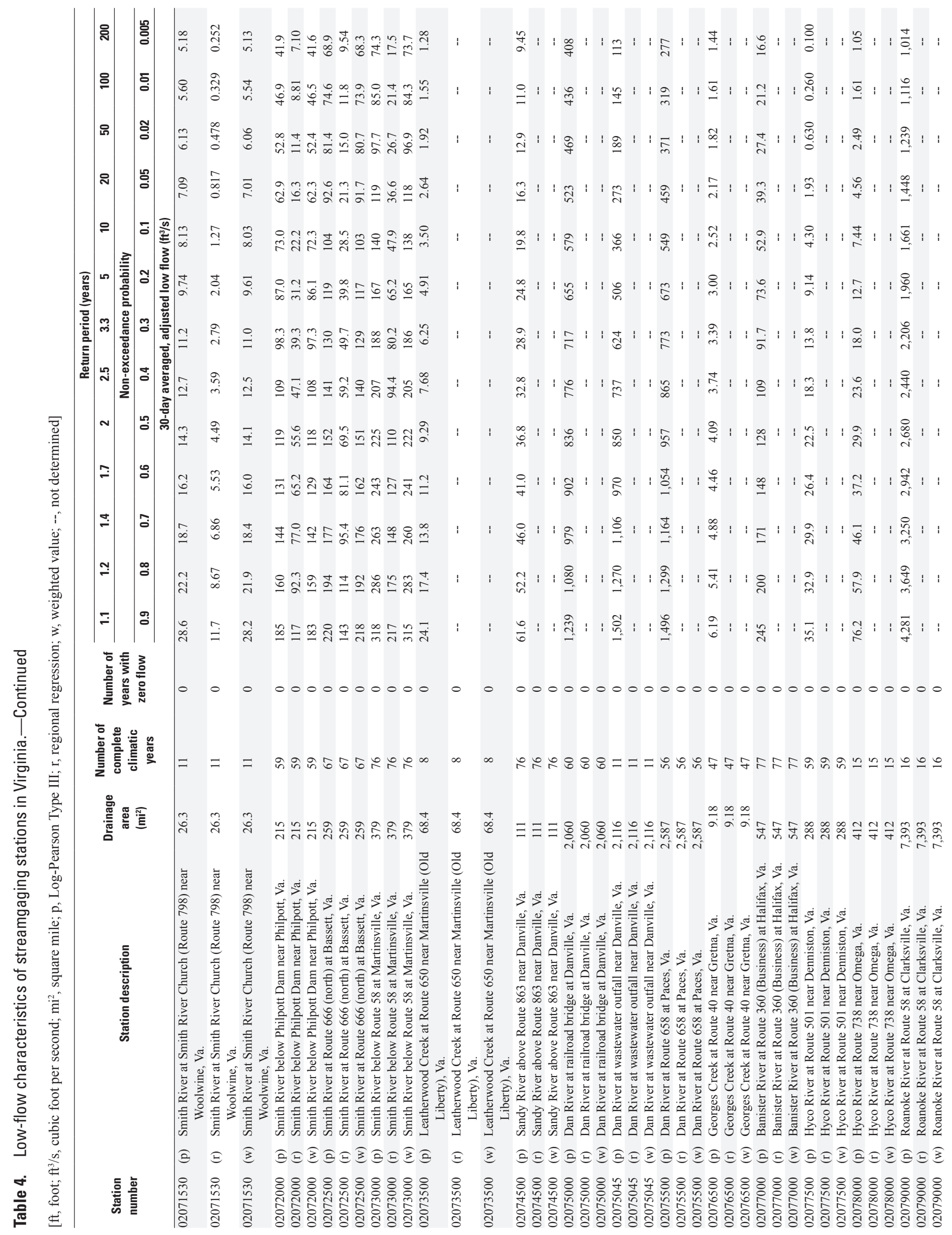




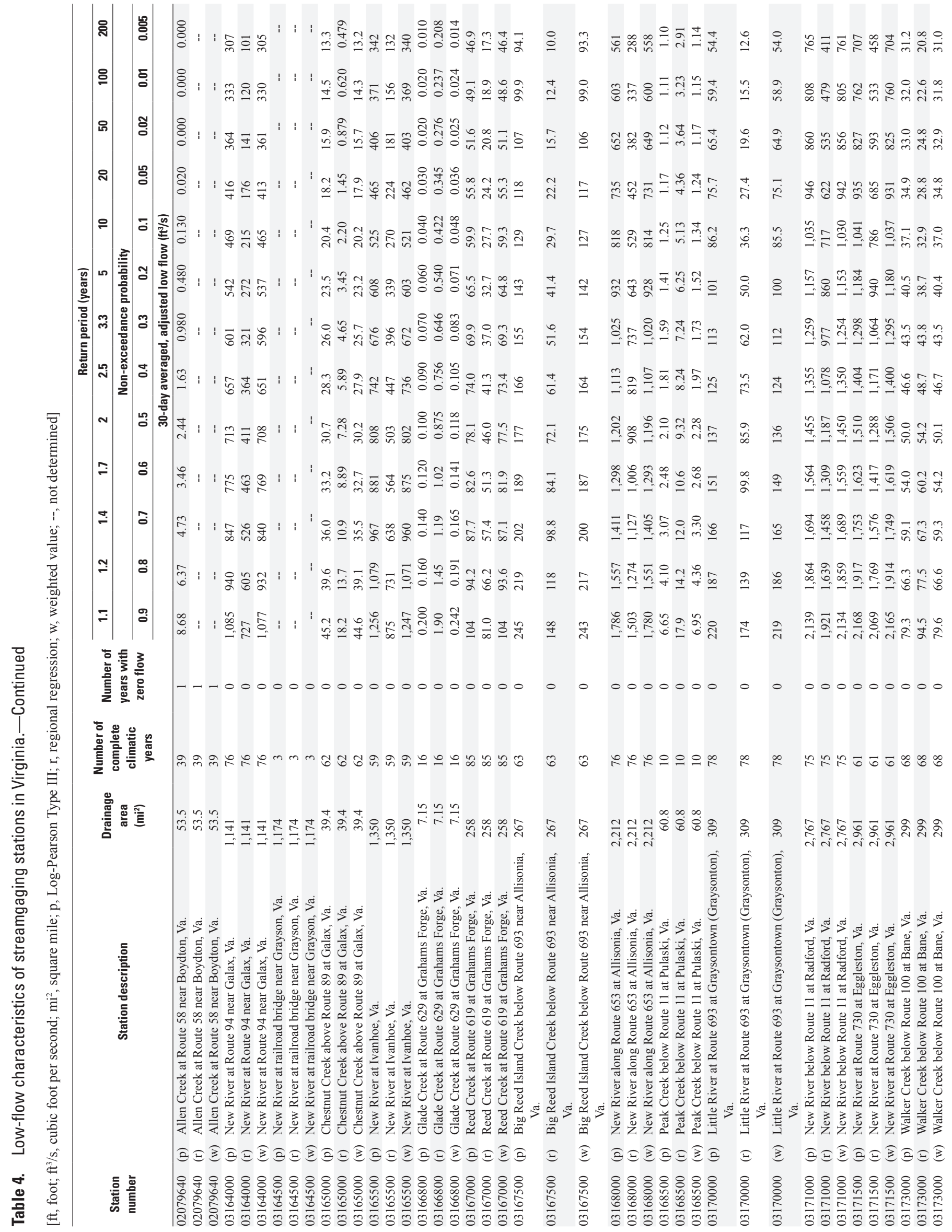




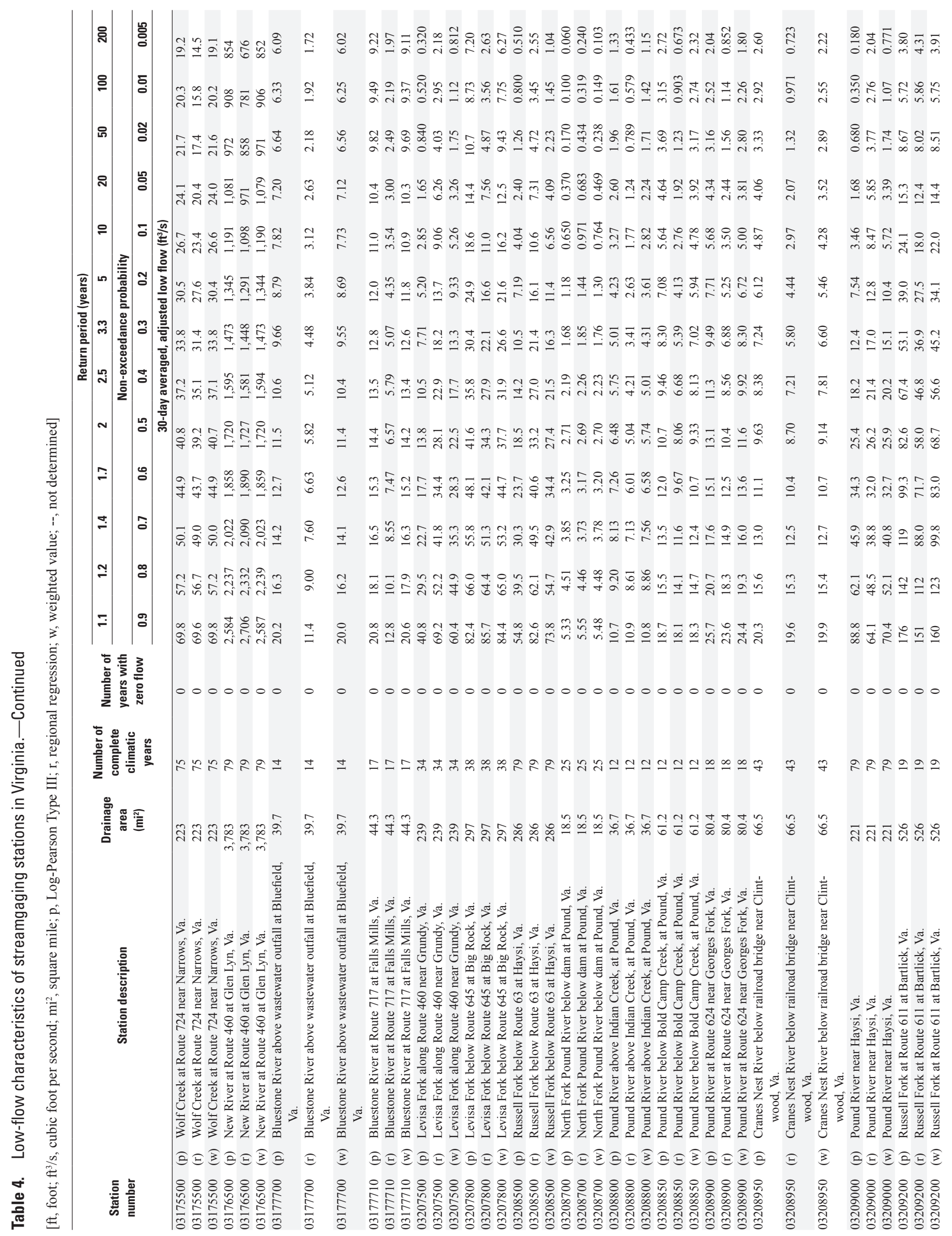




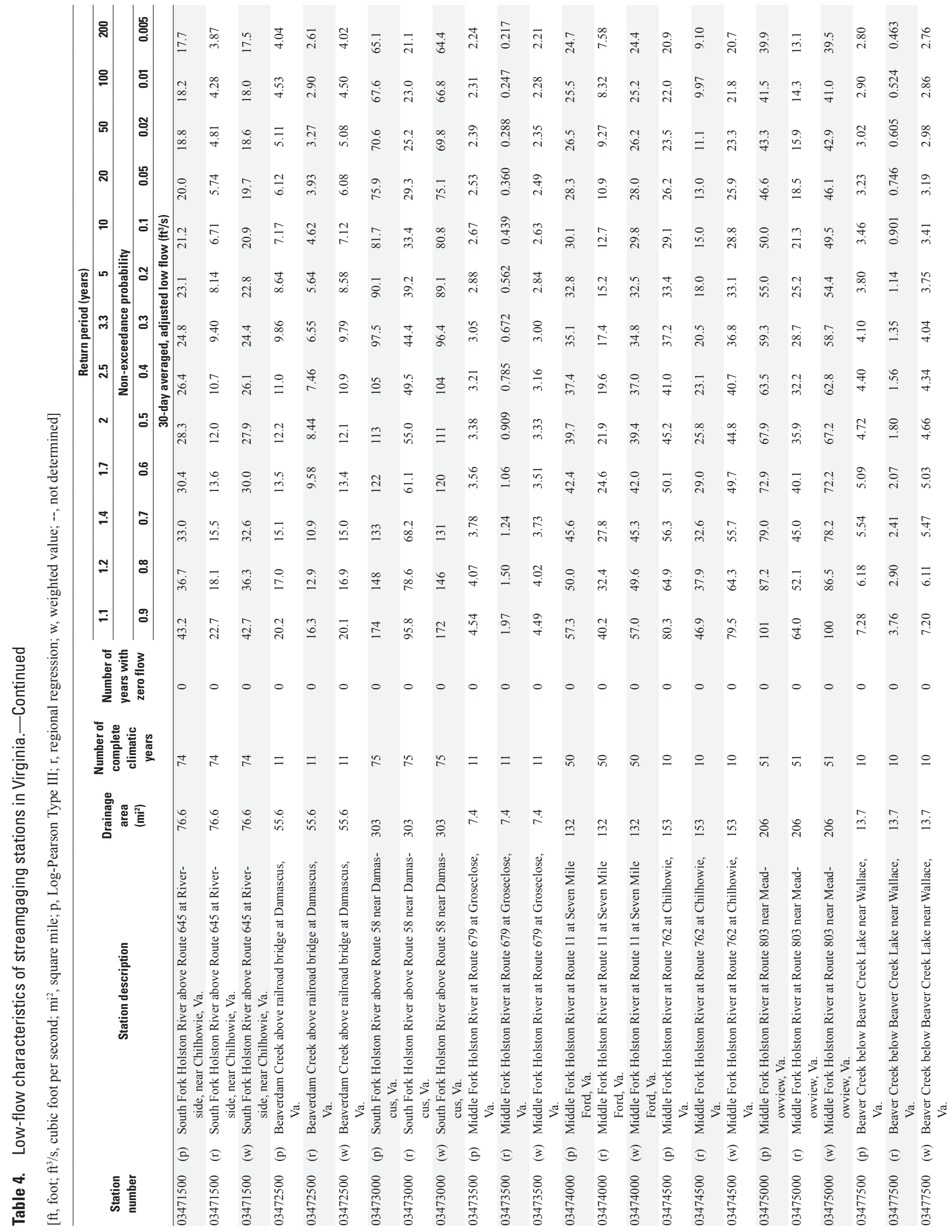




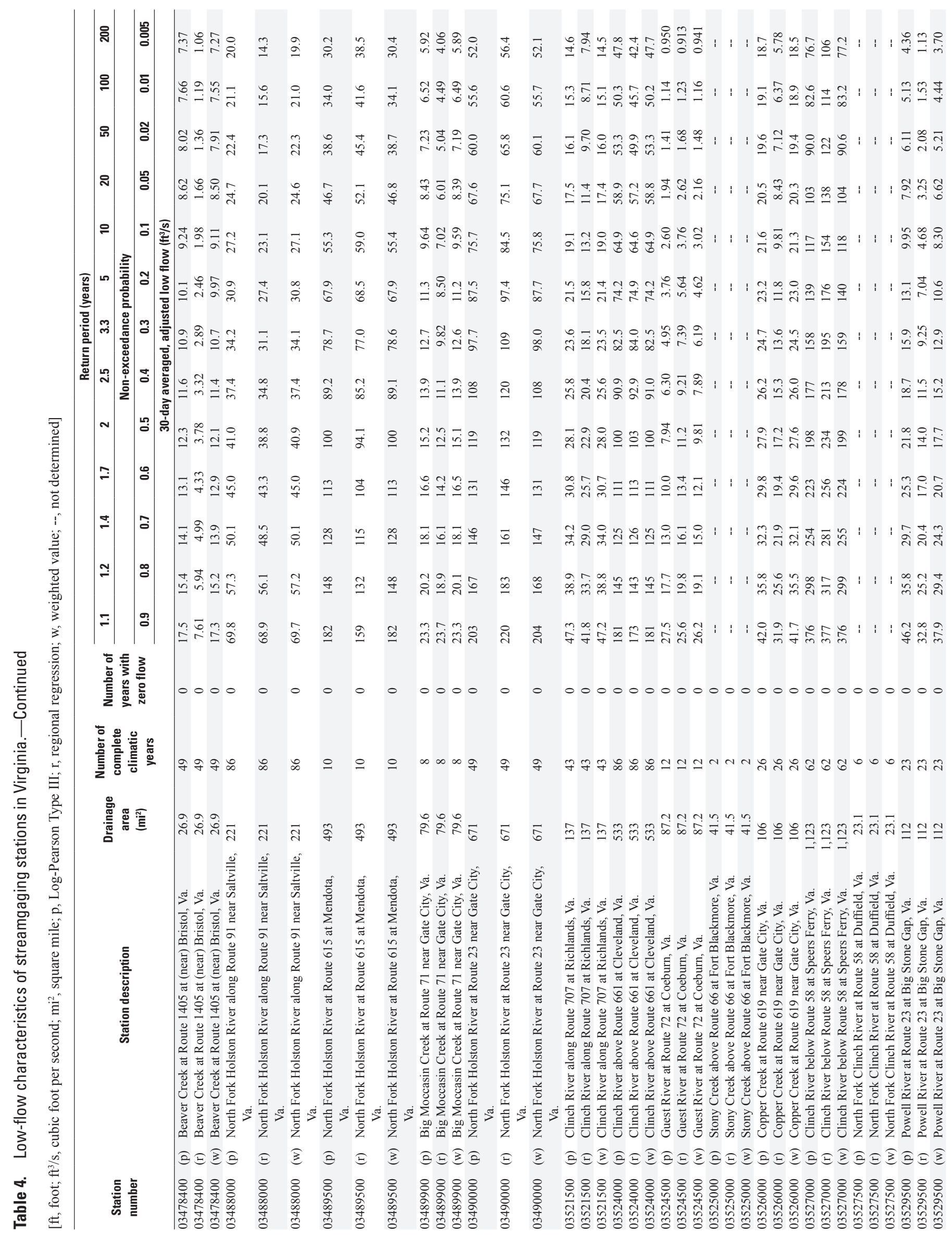




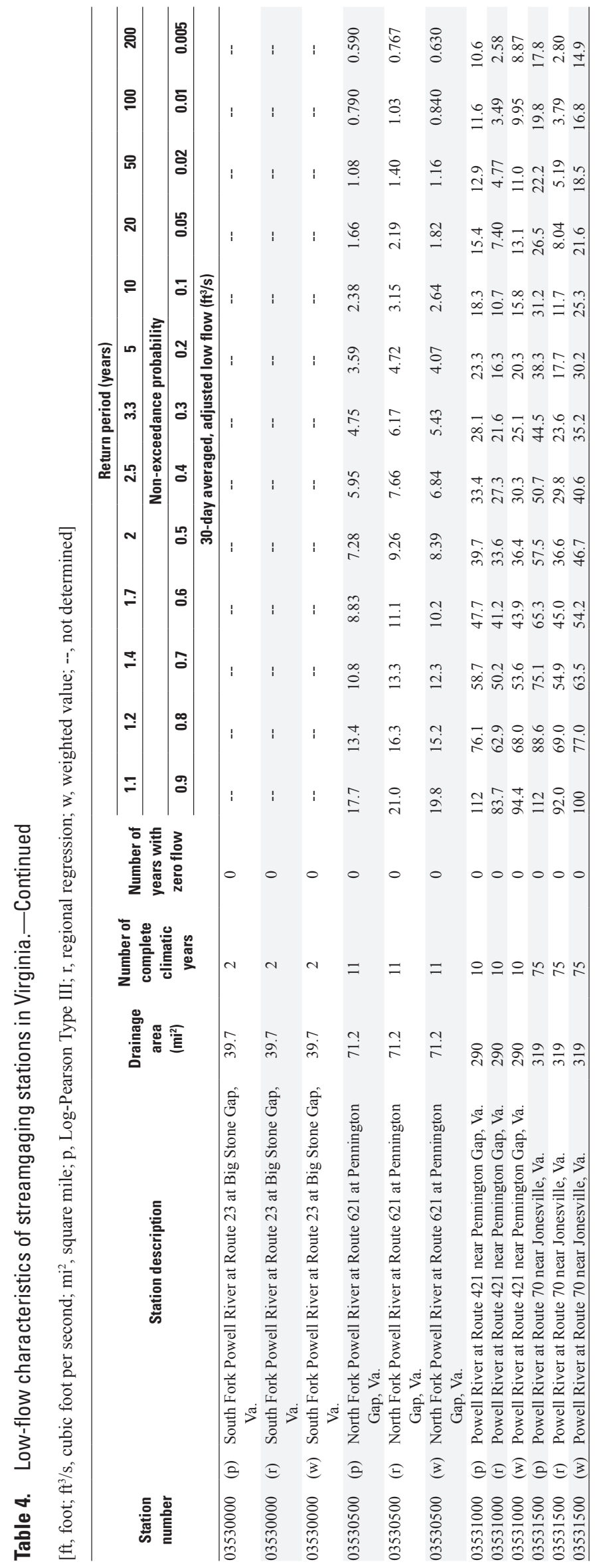


Manuscript approved on August 22, 2011.

\section{Prepared by:}

USGS Science Publishing Network

Raleigh Publishing Service Center

3916 Sunset Ridge Road

Raleigh, NC 27607

For additional information regarding this publication, contact:

Samuel H. Austin, Hydrologist

USGS Virginia Water Science Center

1730 East Parham Road

Richmond, Virginia 23228

phone: 804-261-2600

e-mail: saustin@usgs.gov

Or visit the Virginia Water Science Center Web site at: http://va.water.usgs.gov

A PDF version of this publication is available online at http://pubs.usgs.gov/sir/2011/5143/ 
